\title{
A CLÍNICA DO TRAUMA E OS ESTADOS REGRESSIVOS NO SETTING PSICANALÍTICO
}

\begin{abstract}
Tese de Doutorado
Tese apresentada ao Programa de Pós-graduação em Psicologia (Psicologia Clínica) da PUC-Rio como requisito parcial para obtenção do grau de Doutor.
\end{abstract}

Orientador: Prof. Carlos Augusto Peixoto Junior

Rio de Janeiro, Abril de 2018. 


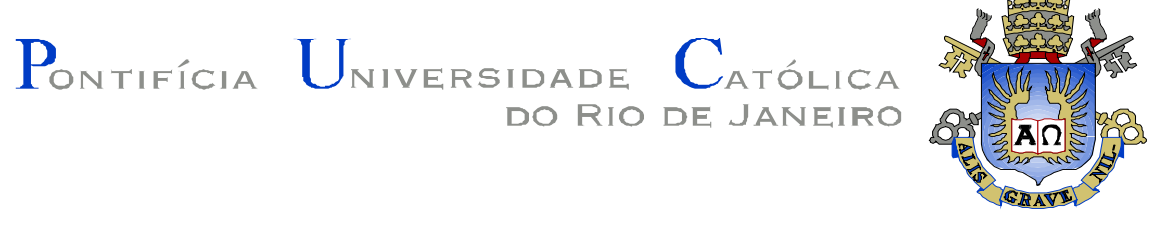

Gabriel Cunha Nunes

\section{A clínica do trauma e os estados regressivos no setting analítico}

Tese apresentada como requisito parcial para obtenção do grau de Doutor pelo Programa de Pós-Graduação em Psicologia (Psicologia Clínica) da PUC-Rio. Aprovada pela Comissão Examinadora abaixo assinada.

Prof. Carlos Augusto Peixoto Junior Orientador

Departamento de Psicologia - PUC-Rio

Profa. Silvia Maria Abu-Jamra Zornig

Departamento de Psicologia - PUC-Rio

Profa. Hélia Maria Oliveira da Costa Borges Faculdade Angel Vianna - FAV

Prof. Aluisio Pereira de Menezes Faculdades Integradas Hélio Alonso - FACHA

Profa. Ana Lila Lejarraga UFRJ

Profa. Monah Winograd Coordenadora Setorial de Pós-Graduação e Pesquisa do Centro de Teologia e Ciências Humanas - PUC-Rio

Rio de Janeiro, 04 de abril de 2018. 
Todos os direitos reservados. É proibida a reprodução total ou parcial do trabalho sem autorização da universidade, do autor e do orientador.

\section{Gabriel Cunha Nunes}

Graduou-se em Psicologia em 2010 pela PUC-Rio. Mestre em Psicologia Clínica pela PUC-Rio em 2013 e Bolsista FAPERJ Nota 10 durante o Mestrado (2012) e Doutorado (2016 e 2017). Atua como psicólogo clínico desde 2010.

Ficha Catalográfica

Nunes, Gabriel Cunha

A clínica do trauma e os estados regressivos no setting psicanalítico / Gabriel Cunha Nunes ; orientador: Carlos Augusto Peixoto Junior. - 2018. 190 f. ; $30 \mathrm{~cm}$

Tese (doutorado)-Pontifícia Universidade Católica do Rio de Janeiro, Departamento de Psicologia, 2018.

Inclui bibliografia

1. Psicologia - Teses. 2. Trauma. 3. Regressão. 4. Setting. 5. Interpretação. 6. Confusão de línguas. I. Peixoto Junior, Carlos Augusto. II. Pontifícia Universidade Católica do Rio de Janeiro. Departamento de Psicologia. III. Título. 


\section{Agradecimentos}

Ao meu orientador, Professor Carlos Augusto Peixoto Junior, pelo apoio ao longo desses anos, pelas sugestões, críticas e também por sua leitura atenta, que tanto enriqueceu este trabalho.

Aos integrantes da banca, por aceitarem gentilmente o convite para participar de minha defesa.

Às professoras Ana Lila Lejarraga e Silvia Zornig, por terem contribuído tanto para esta tese no meu exame de qualificação.

À CAPES, à FAPERJ e à PUC-Rio, pelos auxílios concedidos que tornaram possível a realização deste trabalho.

Aos funcionários do Departamento de Psicologia da PUC-Rio, especialmente à Marcelina, à Vera e ao Edson, pelo socorro sempre que necessitei.

À Regina Murat, que tanto me ajudou a ser cada vez mais quem sou.

Às professoras Mariângela Monteiro e Luciana Pessôa, por terem me proporcionado um convívio tão enriquecedor.

Aos colegas da pós-graduação, pelos diálogos constantes.

À revisora Sonia Argollo, pela leitura que a cada arquivo me torna um escritor melhor.

Aos amigos, pela compreensão nos momentos de ausência.

A toda minha família, por sempre me apoiar e incentivar.

À Bruna, por ter me dado o apoio sem o qual não seria possível escrever essa tese. Pelo amor, pela convivência, por nosso passado, presente e futuro. Por tudo. 


\section{Resumo}

Nunes, Gabriel Cunha; Peixoto Junior, Carlos Augusto (orientador). A clínica do trauma e os estados regressivos no setting psicanalítico. Rio de Janeiro, 2018, 190 p. Tese de Doutorado - Departamento de Psicologia, Pontifícia Universidade Católica do Rio de Janeiro.

O presente trabalho tem como objetivo investigar o conceito de trauma na psicanálise, bem como a regressão terapêutica como via de elaboração do evento traumático não representado psiquicamente a partir da situação analítica. Para isso, na primeira parte deste trabalho, analisaremos a noção de trauma a partir da perspectiva de Sándor Ferenczi, considerando o percurso teórico do autor que lhe permitiu formular a ideia do trauma constituído em dois tempos, a partir de uma confusão de línguas. Na segunda parte, acompanharemos os desdobramentos diretos e indiretos dessa teoria na Escola Inglesa de Psicanálise, representada por dois autores pertencentes ao grupo independente: Donald W. Winnicott e Michael Balint. Exploraremos então o funcionamento psíquico primitivo do indivíduo e o papel exercido pelo ambiente na constituição subjetiva, assim como as intensas falhas ambientais e as funções patogênicas das mesmas, ou seja, as repercussões do trauma como um evento catastrófico que interrompe o desenvolvimento emocional. $\mathrm{Na}$ terceira parte, adentraremos uma discussão clínica, reconhecendo as bases que constituem o setting analítico, compreendendo os diferentes usos das interpretações e as manifestações clínicas da regressão como uma nova chance de liquidação e elaboração do material traumático. Por fim, realizaremos um exame sobre as propostas da psicanálise contemporânea a partir das ideias da psicanálise do colapso, de Christopher Bollas; do terceiro analítico, de Thomas H. Ogden; e da empatia psicanalítica, de Stefano Bolognini, mostrando novas concepções a respeito da clínica do trauma e do manejo de casos regressivos no pensamento psicanalítico atual.

\section{Palavras-chave}

Trauma; regressão; setting; interpretação; confusão de línguas 


\section{Abstract}

Nunes, Gabriel Cunha; Peixoto Junior, Carlos Augusto (Advisor). The clinic of trauma and the regressive states in the analytic setting. Rio de Janeiro, 2018, 190 p. Tese de Doutorado - Departamento de Psicologia, Pontifícia Universidade Católica do Rio de Janeiro.

The present work aims to investigate the concept of trauma in psychoanalysis, as well as therapeutic regression as a way to elaborate the unrepresentable traumatic event through the analytical situation. To achieve this goal, on the first part of this work, we will analyze the notion of trauma from Sándor Ferenczi's perspective, considering the theoretical course that allowed him to formulate de idea of a trauma constituted in two times, from a confusion of tongues. On the second part, we will follow the direct and indirect unfolding of this theory in the English School of Psychoanalysis, represented by two authors belonging to the independent group: Donald W. Winnicott and Michael Balint. We shall explore then the primitive psychic functioning of the individual and the role played by the environment on the subjective constitution, as well as the severe environmental flaws and their pathogenic functions, i. e. the repercussions of the trauma understood as a catastrophic event that disrupts the emotional development. On the third part we will enter a clinical discussion, recognizing the principles that shape the analytical setting, comprehending the different uses of interpretations and the clinical manifestations of regression as a new opportunity to liquidate and elaborate the traumatic material. Lastly we shall examine the contemporary psychoanalysis' suggestions over the ideas of the psychoanalysis of breakdown, by Christopher Bollas; the analytic third, by Thomas H. Ogden; and the psychoanalytic empathy, by Stefano Bolognini, show new concepts over the clinic of trauma and about how to handle regressive cases in the current psychoanalytic thought.

\section{Keywords}

Trauma; regression; setting; interpretation; confusion of tongues. 


\section{Sumário}

1. Introdução 9

2. Os tempos do trauma na teoria ferencziana 14

$\begin{array}{ll}\text { 2.1. A técnica ativa } & 17\end{array}$

2.2. As inovações clínicas depois da atividade 21

2.3. A teoria do trauma 24

2.3.1. A confusão de línguas e o trauma patogênico 29

2.3.2. A progressão traumática 42

3. O trauma segundo Balint e Winnicott 49

3.1. Balint - do amor primário à falha básica 50

3.1.1. Amor primário e narcisismo primário 50

3.1.2. A falha básica e as três áreas da mente 64

3.2. Winnicott - o funcionamento psíquico primitivo e a ruptura da continuidade de ser

3.2.1. O funcionamento psíquico precoce e o ambiente $\begin{array}{ll}\text { suficientemente bom } & 70\end{array}$

3.2.2. Desenvolvimento emocional primitivo 73

3.2.3. Os sentidos do trauma em Winnicott 79

4. A clínica do trauma - regressão no setting psicanalítico 87

4.1. O setting psicanalítico 88

4.2. As formas de transferência 95

4.3. As interpretações no contexto da regressão a estados primitivos 102

4.4. A regressão na situação psicanalítica 108

5. Perspectivas contemporâneas sobre a clínica do trauma 132

5.1. Christopher Bollas e a psicanálise do colapso 132

5.1.1. Selves partidos 134

5.1.2. A clínica do colapso: uma nova visão do setting 137 
5.2. Thomas Ogden - Rêverie, interpretação e o terceiro analítico 150

5.2.1. A posição autista-contígua 150

5.2.2. O terceiro analítico intersubjetivo e a rêverie 157

5.3. Stefano Bolognini - o interpsíquico na clínica italiana 163

5.3.1. A empatia psicanalítica 165

5.3.2. Aplicações clínicas da empatia psicanalítica 169

6. Considerações finais 177

$\begin{array}{ll}\text { 7. Referências bibliográficas } & 181\end{array}$ 


\section{Introdução}

É bastante comum (e até mesmo importante), nas primeiras entrevistas, indagar ao paciente as razões que o levaram a buscar análise ou terapia, caso o mesmo já não o faça por si. Os motivos são tão variados quanto as cores do arcoíris - embora seja possível encontrar alguns padrões que lhes agrupem em poucas categorias, um olhar mais próximo revela que cada um é único. Algumas questões são comuns, aparentemente simples e bastante recorrentes. Entre as justificativas expostas a nós, podemos destacar, por exemplo, a depressão, crises de pânico, fobias variadas ou o estresse. Há a dificuldade para se relacionar com os outros, seja em casa, no trabalho ou qualquer tipo de meio social. Uma resistência a deixar a casa dos pais, ainda que se tenha condições objetivas para tal. Diversos tipos de adicções: álcool, drogas, remédios e, nos dias de hoje, até a utilização de dispositivos tecnológicos. Há também quem busque ajuda para lidar com os efeitos, sejam eles primários ou secundários, de doenças graves, como câncer, HIV ou as sequelas de um acidente vascular cerebral. Encontramos ainda aqueles que foram encaminhados à psicoterapia por uma outra figura, como a escola, no caso de crianças, ou, para adultos, a instituição na qual trabalham. Neste caso, a demanda pode ser externa, e muitas vezes o paciente nem mesmo sabe ao certo porque está em um ambiente psicoterapêutico.

Por outro lado, existem queixas mais complexas, que remetem a um nível psíquico mais profundo e misterioso. Suas motivações exalam um certo mistério, como se apenas sua silhueta pudesse ser observada. Fairbairn (1940), por exemplo, ao referir-se à forma com que o paciente esquizoide se apresenta à análise, sugere que é característico dele afirmar que sua motivação em relação à terapia se baseia em um fundamento aparentemente inadequado - porque lhe faria bem ou simplesmente porque lhe parece interessante. Segundo o autor escocês, há ainda aqueles que "entram no consultório com um ar misterioso ou perplexo, e que iniciam a conversa com uma citação de Freud ou com uma observação tal como 'na realidade, não sei por que vim'." (Fairbairn, 1940/1980, p. 5). O autor não exclui da categoria de pacientes esquizoides aqueles que apresentam de antemão uma queixa baseada em um sintoma manifesto, até mesmo por considerar que, de forma 
mais ou menos severa, a esquizoidia seria um fenômeno universal (Greenberg \& Mitchell, 1989/1994). No entanto, o eclipse que obscurece o real motivo pelo qual se buscou o atendimento psicológico - decerto uma ferida - acaba por revelar uma importante defesa de parte do paciente.

Vincenzo Bonaminio (2008/2008) sugere, baseado em Balint (1957), que aquilo que o paciente apresenta ao médico é, na realidade, uma "doença não organizada", oferecendo-lhe uma coleção de sintomas, um sofrimento indefinido, a partir de manifestações de doenças ou dores persistentes, sinais de cansaço ou insônia. De acordo com o autor, no contexto analítico, cabe ao profissional acolher essa comunicação, sustentando ao menos por um tempo suficiente a não organização dessa doença sem que se imponha necessariamente uma tentativa verbal de organizá-la. Isso é especialmente importante quando essas questões remetem a momentos primitivos da vida psíquica, em que a linguagem verbal ainda não havia sido alcançada e os afetos e sofrimentos não poderiam, portanto, ser representados.

De uma forma ou de outra, podemos determinar que toda essa problemática a respeito da queixa que o paciente apresenta (ou não) ao analista revolve em torno de um mesmo ponto - o trauma, questão que recebeu uma ampla variedade de abordagens ao longo da construção do pensamento psicanalítico. A concepção psicanalítica sobre o trauma começa com um caráter real, presente nos primórdios da psicanálise, passa pela reconsideração freudiana sobre a essência fantasística do mesmo e desemboca em uma infinidade de revisões, trazendo novas concepções e perspectivas acerca da constituição traumática.

Decerto, a elaboração teórica do conceito de trauma exercerá uma função crucial na clínica, tendo em vista que a relação terapêutica se baseia nas capacidades comunicativas do paciente - sua linguagem -, que por sua vez se constroem sobre as bases de suas constituições subjetivas. Como veremos ao longo desta tese, a atitude clínica de cada psicanalista é ricamente influenciada pela sua visão a respeito do sofrimento que o paciente lhe apresenta, assim como do trauma referente a essa angústia. Alguns casos, por exemplo, dizem respeito a situações traumáticas vivenciadas em momentos muito primitivos, o que pode impossibilitar o trabalho analítico baseado na técnica interpretativa clássica, exigindo uma postura 
diferente da parte do analista. Esse tipo de paciente costuma exibir uma atitude regressiva, acompanhada de uma tendência a estabelecer um vínculo e uma comunicação de natureza bastante primitiva. Isso nos leva a questionar: como pode o analista acompanhar e manejar essa situação regressiva, adentrando uma jornada que transcende nosso mundo compartilhado das palavras?

A partir de minha experiência clínica, notei que muitos fenômenos ocorridos nas sessões de alguns pacientes possuíam uma grande intensidade emocional. O intenso sofrimento do paciente, embora muitas vezes indescritível em palavras, se fazia muito presente no consultório, sendo quase palpável. O trabalho verbal se mostrava não apenas ineficaz nessas situações, chegava a parecer dispensável - tudo que havia para ser dito já fora sentido e provocado. Por outro lado, uma dimensão relacional parecia assumir o protagonismo terapêutico enquanto minha produção interpretativa era emocionalmente ignorada, a capacidade do paciente em manter-se uno e, posteriormente, de acessar e elaborar um material que lhe era até então desconhecido dependiam da forma com que me apresentava. Foi-me necessário, então, voltar-me para alguns autores que recomendavam um tipo específico de clínica, direcionada a fenômenos regressivos que apontavam a um trauma que não podia ser verbalizado por não ter sido representado no psiquismo.

Assim, com o objetivo de compreender a construção da noção de trauma e colapso ao longo dos tempos e das formas clínicas de regressão que acompanham as tentativas de elaboração desse trauma, selecionamos alguns autores que nos ofereceram contribuições seminais no campo da psicanálise, todos dotados de uma grande espírito inovador e de grande sensibilidade na relação terapêutica.

Considerando o objetivo acima, esta tese foi dividida em quatro capítulos. No primeiro, abordaremos algumas formulações a respeito do trauma que datam das primeiras décadas da psicanálise. Destacaremos as importantes contribuições teórico-clínicas de Sándor Ferenczi a respeito desse tema, explorando a importância atribuída pelo autor húngaro aos componentes reais da relação entre a criança e o ambiente tanto na construção quanto na consolidação do trauma, bem como as inevitáveis repercussões que esse evento terá na relação terapêutica. 
No capítulo seguinte, analisaremos as contribuições sobre o evento traumático e seus ecos ao longo do desenvolvimento psíquico do sujeito sugeridas por dois psicanalistas posteriores, reconhecidos por sua grande contribuição no campo clínico: Michael Balint e D. W. Winnicott. Notaremos ainda a influência (seja ela direta ou indireta) exercida por Ferenczi na obra dos dois autores, principalmente a partir da relevância do ambiente na constituição psíquica do indivíduo e da construção de um modelo de desenvolvimento baseado na dinâmica relacional.

No terceiro capítulo, investigaremos os aspectos clínicos das propostas desses três autores a respeito do papel da regressão na clínica do trauma, especialmente a partir dos conceitos de elasticidade da técnica de Ferenczi, das regressões benigna e maligna discutidas por Balint e do manejo diante dos casos de regressão à dependência absoluta, conforme descrito por Winnicott. Para tal, exploraremos ainda os fundamentos da noção de setting psicanalítico, assim como o papel da interpretação nesse contexto. É importante destacar que, embora esses autores considerem que o trauma ocorre em diferentes níveis, podendo inclusive ser relativo a um momento mais avançado do desenvolvimento psíquico, como uma dinâmica edipiana, seu grande interesse clínico recaía sobre os casos mais primitivos e a diferente relação que se estabelece junto com esses pacientes. Será esse também, portanto, nosso foco ao discutir as propostas clínicas de Ferenczi, Balint e Winnicott, bem como alguns casos relatados pelos autores e algumas experiências clínicas que vivenciamos nesse contexto de regressão.

Por fim, no quarto capítulo, trataremos de algumas contribuições contemporâneas a respeito dessa forma peculiar da clínica, optando por discutir as ideias de três autores que se caracterizam por uma grande diferença de abordagem ao mesmo tempo em que se propõem a observar e trabalhar fenômenos semelhantes: Christopher Bollas, Thomas Ogden e Stefano Bolognini. Trata-se de autores que mantém, nos dias de hoje, uma rica e frequente contribuição na área da análise de casos designados por sofrimentos intensos e irrepresentáveis, e que compartilham com Ferenczi, Winnicott e Balint um princípio inovador dentro da psicanálise, orientados pelas necessidades do paciente e sua cura, no sentido de um alívio do 
sofrimento por meio da possibilidade da representação do trauma através da relação analítica.

A partir das construções teóricas abordadas, pretendemos desenvolver uma articulação com aspectos clínicos da regressão, ao analisar a forma com que esses autores e alguns comentadores lidam com o acesso ao material referente ao trauma por uma via interpsíquica. Se o trauma, como veremos a partir da obra ferencziana, remete a um evento irrepresentável, o acesso desse material ao analista deverá ocorrer por vias pouco exploradas, cada uma elaborada de forma única a partir da relação analista-paciente em uma dimensão regressiva. Analisaremos, então, alguns casos clínicos expostos pelos autores que compõem essa tese, bem como algumas situações de minha própria experiência clínica que ajudem a ilustrar a forma com que esses fenômenos ocorrem. 


\section{Os tempos do trauma na teoria ferencziana}

A contribuição de Sándor Ferenczi para a psicanálise é, decerto, controversa. Desde seus primeiros contatos com os escritos psicanalíticos e com o próprio Freud, no fim da primeira década do século XX, Ferenczi demonstrou grande preocupação com o progresso e o desenvolvimento da teoria e da clínica psicanalítica. Antes mesmo do primeiro encontro com Freud em 1908, quando passa a integrar a Sociedade Psicológica das Quartas-Feiras, Ferenczi publicara um considerável número de artigos médicos cujos assuntos evidenciavam seu interesse pelas questões de ordem psíquica - sobre homossexualidade feminina, neurastenia e hipnose, por exemplo.

Pinheiro classifica Ferenczi como "[...] um clínico de extrema sensibilidade e perspicácia [...]" (Pinheiro, 2016, p. 49), mesmo em seus primeiros trabalhos publicados a partir de um viés psicanalítico. Bokanowski (2000/2000) o descreve como culto, eclético, curioso e, principalmente, inquieto; seu impulso a cuidar do outro o teria levado a uma disposição à experimentação clínica que prezava sempre pelo bem-estar do paciente. Pinheiro complementa: "Ele é, antes de tudo, um psicanalista, um clínico, um clínico inquieto, buscando compreender o que é obscuro, recusando as fórmulas fáceis, questionando o que teoricamente parece bem encadeado, mas que a clínica não confirma” (Pinheiro, 2016, p. 50). Michael Balint, seu principal discípulo e um dos maiores divulgadores de sua obra, define Ferenczi em uma palavra: médico. No entanto, Balint propõe uma compreensão dessa palavra em um sentido mais complexo, que transcende a atividade médica em si. O autor, então, corrobora essa visão sobre a inquietude de Ferenczi: "Sua mente era ativa, pode-se dizer inquieta, sempre alerta, sempre questionadora, então sua atividade científica, naturalmente, não poderia ser confinada dentro dos limites da medicina. [...] Seu único objetivo, aquele do qual ele nunca perdeu o foco, se tornou aliviar os sofrimentos de pessoas mentalmente enfermas" (Balint, 1933a, p. 235).

Talvez tenha sido justamente essa inquietude a característica de Ferenczi que em um primeiro momento tanto fascinou Freud, levando a uma relação de inigualável intimidade entre os dois e que, posteriormente, conduziria a um 
acentuado rompimento teórico e pessoal. A constante preocupação de Ferenczi com a clínica psicanalítica o levou a questionar a própria psicanálise e o papel do analista, função que precisava, em sua visão, ser destituída de qualquer caráter estático - deveria ser revista e reinventada de acordo com a necessidade específica do paciente. Segundo Birman (1996) o grande "problema" que Ferenczi criou com a comunidade psicanalítica, principalmente a partir de 1929, e que resultaria em sua exclusão do movimento

[...] era se perguntar alguma coisa que qualquer psicanalista honesto com a sua atividade deveria se perguntar todo dia de manhã: 'O que é ser psicanalista? $\mathrm{O}$ que é essa tal de 'senhora psicanálise'?' Onde Ferenczi incomodou os psicanalistas é que ele colocou e recolocou essas questões repetidas vezes, desde 1929 até o momento da sua morte; formulou diferentes respostas para esse tipo de questão. (Birman, 1996, p. 69)

O questionamento da psicanálise que orientou Ferenczi o levou a um olhar mais atento a si mesmo como psicanalista, o que permitiu que o autor húngaro desenvolvesse uma série de avanços e reviravoltas em termos da técnica psicanalítica. Se Ferenczi é o autor de uma obra permeada pelo erro, como afirma Casadore (2012), foi justamente a aceitação da possibilidade do erro, tanto o possivelmente vindouro quanto aquele já cometido, que permitiu que uma formulação tão original da psicanálise fosse elaborada. Balint (1933a) afirma que Ferenczi era um psicanalista que mantinha-se aberto a rever sua técnica, sempre orientado pelo caráter terapêutico da análise.

Segundo Bokanowski (2000/2000), é possível perceber três períodos distintos na obra de Ferenczi. O primeiro, entre seu primeiro contato com Freud em 1908 e 1914, é caracterizado pela prevalência de uma contribuição para os postulados freudianos já estabelecidos e em desenvolvimento nesse momento. A principal contribuição de Ferenczi nesse período é a elaboração do conceito de introjeção, em texto de 1909 (Transferência e introjeção), apenas um ano após o primeiro encontro com Freud. Neste artigo, ao opor a problemática do esquizofrênico e do paranoico (o primeiro retira o interesse do mundo externo, enquanto que o segundo projeta seus desejos e tendências no mundo exterior) à do neurótico, que inclui no âmbito do seu interesse o máximo possível do mundo externo, Ferenczi delimita com mais rigor o processo da introjeção: "Este é o efeito da Süchtigkeit, impulsão, tendência e aspiração que o sujeito tem para incluir o 
mundo externo no 'ego', processo que está na própria base da transferência" (Bokanowski, 2000/2000, p. 49, grifado no original).

Ferenczi (1909/2011) estabelece, então, que no início a criança experimenta tudo de forma monista, seja a fonte da experiência interna ou externa. No entanto, com o passar do tempo ela consegue distinguir aquilo que é submetido à sua vontade do que é independente de sua ação. Assim, o mundo externo é constituído e a primeira operação projetiva, a projeção primitiva, é possibilitada, permitindo à criança a ejeção de afetos desagradáveis para o exterior. Contudo, o mundo externo continua a se impor, como que por desafio (ama-me ou odeia-me), dificultando essa expulsão, o que propicia a introjeção primitiva:

E o ego cede a esse desafio, reabsorve uma parte do mundo externo e a incluirá em seu interesse: assim se constitui a primeira introjeção, a 'introjeção primitiva'. O primeiro amor, o primeiro ódio realizam-se graças à transferência: uma parte das sensações de prazer ou de desprazer, autoeróticas na origem, desloca-se para os objetos que as suscitaram. (Ferenczi, 1909/2011, p. 96)

Assim, Ferenczi determina a importância da introjeção como processo organizador da psique, inclusive como base para a transferência. Posteriormente, em $O$ conceito de introjeção, Ferenczi declararia ainda que “[...] o homem só pode amar-se a si mesmo e a mais ninguém; amar a outrem equivale a integrar esse outrem no seu próprio ego." (Ferenczi, 1912/2011, p. 209). Ou seja, todas as relações ulteriormente estabelecidas (inclusive a relação analítica) teriam como fundamento o processo de introjeção vivido na infância inicial. Não obstante, é importante destacar a definição que Bokanowski imprime para a introjeção. Segundo ele, a introjeção consiste na internalização do Outro e do desejo deste, sendo aquilo “[...] que permite, no sujeito, a transformação do narcisismo primário em narcisismo secundário e a passagem do autoerotismo ao amor objetal." (Bokanowski, 2000/2000, p. 53). Assim, é possível considerar a introjeção proposta por Ferenczi como um precursor do conceito de narcisismo freudiano, mas denotando desde já a importância do outro e do viés relacional nesta formulação. Ainda que autores como Pinheiro (2016) considerem a introjeção como a principal contribuição de Ferenczi, esse conceito foi apenas o princípio de um sinuoso percurso que o autor ainda haveria de percorrer na psicanálise e que o levaria a destacar cada vez mais o papel decisivo da alteridade nos processos de subjetivação. 
A segunda fase da obra de Ferenczi é descrita por Bokanowski (2000/2000) como um período de desenvolvimento de um pensamento já mais singular, que durou de 1914 a 1925. Essa fase é marcada por um interesse destacado pela técnica psicanalítica, assim como pela parceria com Otto Rank (autor do qual, eventualmente, Ferenczi viria a se distanciar). A principal inovação técnica proposta por Ferenczi nessa época foi uma controversa ferramenta - a técnica ativa.

\subsection{A técnica ativa}

Desde o final dos anos 1910, Ferenczi vinha dedicando-se ao reconhecimento da perniciosidade da compulsão à repetição no ambiente clínico. Segundo Bokanowski, "Ela acarreta o lento desaparecimento de muitos tratamentos, ela é a causa de muitos fracassos" (Bokanowski, 2000/2000, p. 66). E foi justamente a partir da dificuldade clínica encontrada diante do material nãoverbalizado, que jaz sob o imensurável poder das resistências, que o autor sugeriu o emprego da técnica ativa. Ainda de acordo com Bokanowski (2000/2000), as resistências surgem de um desligamento da parte do paciente quanto a seus sintomas ao manter-se como observador, sem representar para si esses traços que ficam excluídos de suas associações. Estes sintomas "enquistados” acabam por criar uma grande dificuldade contratransferencial - como não são representados, permanecendo omitidos da cena analítica e das associações do paciente, não há como serem interpretados (o analista não consegue ligar o que vê e sente a algo que seja significável), o que perpetua uma estagnação do processo terapêutico.

Com o intuito de superar essa cristalização da análise, Ferenczi sugere o que chama de técnica ativa, que consiste em incitar o paciente a tomar uma atitude ativa (fazer algo ou renunciar a algo) a partir de injunções ou interdições por parte do analista direcionadas contrariamente ao princípio do prazer, o que consequentemente resultaria em uma elevação da tensão pulsional, situação da qual o paciente não poderia passar inerte - essa tensão proporcionaria o surgimento de um novo material associativo a partir de uma atividade que, até então, não poderia ser realizada. A técnica ativa foi elaborada, portanto, como uma tentativa de radicalização dos princípios freudianos de abstinência e frustração, sendo dessa forma, prontamente acolhido por Freud - o que não aconteceria com suas propostas 
posteriores. Ferenczi menciona esse tipo de contexto ao lidar com casos de histeria de angústia:

Os pacientes, apesar de uma observância rigorosa da 'regra fundamental' e de uma profunda penetração em seus complexos inconscientes, não chegavam a superar certos pontos mortos da análise enquanto não eram incitados a ousar sair do seguro abrigo constituído por sua fobia e a expor-se, a título de ensaio, à situação de que haviam fugido com angústia em virtude de seu caráter penoso. Como era de se esperar, essa tentativa provocava um agudo acesso de angústia. Entretanto, ao se exporem a esse afeto, superavam a resistência contra uma parte do material inconsciente até então recalcado, que a partir daí se tornava acessível à análise sob a forma de ideias e de lembranças. (Ferenczi, 1921/2011, p. 120)

Assim, é importante destacar que a atividade à qual a técnica se refere remete ao paciente e não ao analista. $\mathrm{O}$ analista já desempenharia um papel necessariamente ativo: “A interpretação já seria, para ele [Ferenczi], uma interferência ativa no psiquismo do paciente, pois privilegia uma associação em detrimento de outras e interrompe o livre curso das associações" (Pinheiro, 2016, p. 63). O próprio Ferenczi diria que a atividade “[...] significava uma intervenção ativa muito menos de parte do médico do que por parte do paciente, ao qual era agora imposta, além da observância da regra fundamental, uma tarefa particular. No caso das fobias, essa tarefa consistia em realizar certas ações desagradáveis" (1921/2011, p. 120, grifado no original). Dessa forma, a intenção da técnica ativa seria, segundo Bokanowski (2000/2000), exacerbar e conduzir ao absurdo certos traços de caráter enquistados de maneira que o retorno do recalcado seja facilitado, permitindo assim que as resistências sejam superadas e o processo analítico possa ser retomado - "Quando estimulamos o que está inibido e inibimos o que não está, esperamos somente provocar uma nova distribuição da energia psíquica do paciente (em primeiro lugar, de sua energia libidinal), suscetível de favorecer a emergência do material recalcado" (Ferenczi, 1921/2011, p. 132).

Sobre as indicações da técnica ativa, Ferenczi (1921/2011) deixa claro que seu uso deve se restringir apenas a casos especiais, considerando-a um auxiliar, um complemento da análise, sem nunca servir de substituto para ela. O autor destaca ainda que psicanalistas iniciantes devem abster-se desta técnica, devido à facilidade com que pode levar os pacientes a falsas pistas. Por outro lado, no caso de seu emprego, é importante ter em mente os prejuízos causados quando utilizada em início de análise, uma vez que a solidez da transferência é um elemento fundamental 
para o uso da técnica ativa. Caso o vínculo terapêutico seja frágil, o resultado da frustração infligida pela atividade acaba por ser uma fuga do tratamento - a penosidade da tarefa pode ser vista como uma boa justificativa para o desligamento do analista, abreviando prematuramente a análise. Segundo o autor: "Essa relação do ego com a frustração implica, em primeiro lugar, que a análise jamais deve começar pela atividade. Deve-se, pelo contrário, poupar o ego durante muito tempo ou, pelo menos tratá-lo com muita prudência, senão uma sólida transferência positiva não poderá estabelecer-se” (Ferenczi, 1926/2011, p. 402).

Ferenczi alerta ainda para dois riscos envolvidos no uso da técnica ativa. O primeiro diz respeito justamente ao seu objetivo, a abreviação da análise. Segundo o autor (1921/2011), o paciente pode vir a ser curado "rápido demais" e, portanto, de forma incompleta e apenas aparentemente suficiente. O segundo seria um efeito diametralmente oposto à sua proposta - ao invés de abreviar o tratamento, prolongá-lo, devido à exacerbação das resistências.

Esse segundo ponto, levantado timidamente por Ferenczi no texto de 1921, acabaria por tornar-se uma preocupação central do autor posteriormente. Em Contraindicações da técnica ativa, de 1926, o autor apresenta todas as limitações que encontrou ao empregar essa técnica, indicando as razões para seu fracasso. Uma questão interessante apresentada no texto se refere aos malefícios causados pelo erro, mesmo no caso de um analista experiente. Escreve o autor:

[...] a franqueza obriga-me a confessar que mesmo a experiência não basta para preservar do erro quando se trata da atividade. Devo também participar-lhes as decepções que sofri. Em certos casos, enganei-me manifestamente na minha apreciação da oportunidade ou do alcance das medidas de 'provocação'; a consequência, se queria conservar o paciente, foi ter que confessar o meu erro e, após essa perda de prestígio bastante considerável, deixá-lo desabar seu triunfo sobre mim. De fato, mesmo essa experiência afetiva não deixava de apresentar certas vantagens para a análise, mas acabei me perguntando se ela seria absolutamente necessária e se não teria sido preferível evitá-la. (Ferenczi, 1926/2011, p. 403, grifo meu)

Dessa forma, mesmo quando a repercussão encontrada é positiva, Ferenczi levanta um importante questionamento: é realmente válido correr os riscos que a técnica ativa traz consigo? O abalo que sofre a confiabilidade do analista - aspecto fundamental do processo terapêutico - devido ao erro cometido toma uma especial 
proporção ao considerarmos a responsabilidade que envolve esse tipo de intervenção, como podemos perceber no relato do autor.

Os resultados positivos encontrados por Ferenczi pareciam imprevisíveis, quase aleatórios - ocasionalmente, a técnica ativa mostrava-se bastante produtiva (e até mesmo inevitável), especialmente em casos de final de análise, na dissolução da relação transferencial. Contudo, mesmo nesse tipo de situação, Ferenczi deparava-se com resultados inesperadamente antagônicos. Ao invés de provocar o surgimento e a consequente elaboração da transferência negativa, permitindo a renúncia ao vínculo terapêutico, muitas vezes o que ocorria era uma simples sujeição às injunções do analista - o que evidenciaria um imprevisto fortalecimento das resistências, uma vez que essa atitude passiva representa justamente o movimento de repetição que Ferenczi pretendia evitar a partir da técnica ativa. De acordo com Bokanowski:

[...] os resultados precários e os limites do método o convencem rapidamente da pouca eficácia de tais técnicas. Além do fato de que estas aumentam consideravelmente as resistências do paciente sem que se possa com isso obter uma maior intensidade da frustração ou privação, alguns pacientes parecem aceitar esse crescimento da tensão a fim de preencher seu masoquismo, e sua posição masoquista, no seio mesmo do tratamento. (Bokanowski, 2000/2000, pp. 72-73)

Destarte, o tratamento acaba por se prolongar, uma vez que a submissão do paciente, sua "docilidade" frente ao autoritarismo do analista, evidencia a indissolubilidade da transferência, situação que se origina de uma combinação entre a postura rígida do terapeuta e os anseios masoquistas do paciente. Segundo Pinheiro, "Curiosamente [o paciente] identificava-se com o analista e, submetendose docilmente ao desprazer que lhe era imposto só fazia aumentar sua ligação transferencial. Em suma, o conforto combatido pela técnica ativa permanecia" (Pinheiro, 2016, p. 66). Ferenczi percebe então que o contexto transferencial que se desenrola a partir do uso da técnica ativa revela a defesa que tentava ocultar-se:

Provoquei por vezes uma outra série de dificuldades ao conceber de modo demasiado rígido certas injunções e proibições. De sorte que acabei por me convencer que essas mesmas restrições formais representam um perigo; elas levam o médico a impor à força a sua vontade ao paciente numa repetição exageradamente fiel da situação pais/crianças ou a se permitir posturas perfeitamente sádicas de professor. (Ferenczi, 1926/2011, p. 404, grifo meu) 
O que Ferenczi constata e nos transmite, a partir da citação acima, é que a técnica ativa representa, em essência, uma reedição da situação traumática original, na qual um adulto (nesse caso, na posição dos pais/professor) se sobrepõe forçadamente à subjetividade da criança. Nessa nova circunstância, é o analista quem exige uma igualmente renovada submissão, sem que os sentimentos hostis (a transferência negativa pela qual Ferenczi esperava) tenham chance de aflorar, assim como nas condições originais. Ao tentar suplantar as resistências, o próprio analista assumia o papel de agressor - o único a ser sobrepujado nessa situação seria o paciente em si. Ademais, Ferenczi eventualmente chegaria à conclusão de que o material evocado pela técnica ativa surgiria de uma forma ou de outra, bastando ao analista paciência para esperar por seu surgimento espontâneo. A razão do uso da técnica ativa seria então espelhada na pressa do analista em abreviar o tratamento, o que indica mais uma evidência do seu autoritarismo- no caso, ao impor seu próprio ritmo ao paciente.

Embora a técnica ativa tenha fracassado de forma cabal, tanto na ótica de Ferenczi (1926/2011) como na de diversos comentadores do autor, podemos considerar que essa experiência serviu como um importante ponto de partida para a formulação de uma das mais notáveis contribuições de Ferenczi: a teoria do trauma. O reconhecimento da ideia de que o analista assume um papel de agressor no contexto analítico e de que o paciente submete-se de forma quase que incondicional a ele, constituindo uma repetição de uma situação originária, permitiu a Ferenczi desenvolver toda uma nova teoria sobre a constituição subjetiva que fundamentaria uma igualmente nova postura clínica, baseada na redução da tensão - o princípio do relaxamento ou neocatarse. Segundo o próprio autor, “[...] a tendência para a repetição, que é reforçada pela atividade, foi para mim o meio de chegar não só a fazer progredir a prática psicanalítica mas também a sua teoria" (Ferenczi, 1926/2011, p. 412, grifo meu). Será justamente sobre essas inovações que o presente trabalho se debruçará a seguir.

\subsection{As inovações clínicas depois da atividade}

O abandono da técnica ativa acompanhado do reconhecimento do analista no papel de agressor permitiu a Ferenczi o desenvolvimento e aprofundamento de sua teoria sobre o trauma. No entanto, o interesse do autor sobre esse tópico já não 
era exatamente uma novidade nesse momento. Diversos textos anteriores ao artigo Contraindicações da técnica ativa - datado de 1926, marco do princípio da terceira fase do desenvolvimento da obra de Ferenczi, de acordo com Bokanowski (2000/2000) - já indicavam a importância do trauma patogênico para o autor, como por exemplo, As fantasias provocadas e Thalassa: ensaio sobre a teoria da genitalidade, ambos de 1924, retroagindo pelo menos até as experiências de Ferenczi como médico na Primeira Guerra Mundial, relatadas em Psicanálise das neuroses de guerra, de 1918. Borgogno (1999/2004) considera que, mesmo nas primeiras obras de Ferenczi, no período entre 1908 e 1915, é possível identificar a intuição do autor a respeito da importância do trauma e do abuso sexual para a prática clínica. De qualquer forma, o que chama a atenção é a transformação que esse conceito sofre ao longo da obra ferencziana.

É possível perceber que essa mutação acompanha, segundo Dal Molin (2016), o afastamento que Ferenczi vai tomando em relação à concepção freudiana do trauma - e da teoria e técnica clássica como um todo. Este momento marca uma enfática ruptura com Freud em alguns aspectos. Primeiramente, no eixo clínico, ao sugerir o relaxamento, Ferenczi introduz a ideia de que, em alguns casos que compunham grande parte de sua prática psicanalítica (os chamados casos difíceis), o manejo pode ter um valor terapêutico maior do que as interpretações. Essa formulação é condensada no conceito de tato analítico, definido por Ferenczi (1928/2011) como uma capacidade empática, de “sentir com” (Einfühlung). Segundo o autor, o tato significa:

[...] saber quando e como se comunica alguma coisa ao analisando, quando se pode declarar que o material fornecido é suficiente para extrair dele certas conclusões; em que forma a comunicação deve ser, em cada caso, apresentada; como se pode reagir a uma reação inesperada ou desconcertante do paciente; quando se deve calar e aguardar outras associações; e em que momento o silêncio é uma tortura inútil para o paciente, etc. (Ferenczi, 1928/2011, p. 31)

A citação acima revela com clareza a preocupação do autor em reduzir a tensão a partir de uma atitude de grande proximidade emocional entre analista e paciente, algo que a técnica clássica rejeitava com veemência - atitude que se opunha radicalmente à proposta anterior de Ferenczi relativa ao aumento de tensão gerado pela técnica ativa. Se trata de acompanhar o paciente de acordo com suas tendências e limites, sem que uma postura invasiva seja adotada de parte do analista. 
Segundo Ferenczi, "É necessário, como uma tira elástica, ceder às tendências do paciente mas sem abandonar a tração na direção de suas próprias opiniões, enquanto a falta de consistência de uma ou outra dessas posições não estiver plenamente provada" (Ferenczi, 1928/2011, pp. 36-37). Lejarraga (2008) sugere que, ao postular a elasticidade da técnica, Ferenczi questiona o distanciamento e a postura autoritária adotada pelo analista clássico.

No fim de Elasticidade da técnica psicanalítica, Ferenczi apresenta as críticas feitas por um colega, não identificado no artigo, a respeito de suas ideias sobre o tema em questão. Esse colega indica que se trata de uma ideia perigosa, uma vez que muitos analistas poderiam usá-la como pretexto para justificar seus próprios fatores subjetivos (ainda que Ferenczi chame a atenção ao longo de toda sua obra, inclusive nesse texto, para a necessidade da análise pessoal do analista). Embora o autor húngaro não revele quem o criticava no artigo, é possível saber, através de posteriores publicações, que era Freud o misterioso colega - a correspondência em questão está, inclusive, publicada na íntegra (Freud \& Ferenczi, 2000/2000). Nessa crítica é possível perceber a reprimenda dada por Freud a seu pupilo, que mostrava o interesse por um caminho divergente daquele trilhado por seu mentor. Coelho Junior (2004) chama a atenção para as diferenças entre a relação analítica dentro de uma perspectiva estritamente freudiana, assimétrica e paternalista, e aquela que era então proposta por Ferenczi, marcada pela mutualidade e horizontalidade entre analista e paciente. De forma geral, o que a crítica de Freud nos transparece é que o emprego da elasticidade da técnica teria mais a ver com o analista do que com o paciente: seu uso se basearia nas necessidades do terapeuta, por exemplo, em justificar sua incapacidade de tolerar as tensões surgidas na situação analítica. No entanto, a elasticidade, o princípio de relaxamento e o tato psicanalítico foram as saídas encontradas por Ferenczi para lidar com algo que podemos considerar que havia sido negligenciado por Freud, o caráter externo, real do trauma - o que constitui um segundo ponto que marca o distanciamento entre os dois, em um eixo teórico. A relevância das inovações clínicas propostas por Ferenczi é inegável, marcando uma imensa reviravolta no tratamento das patologias mais severas, os casos difíceis, como o próprio autor classifica. As características dessa clínica ferencziana, baseada na elasticidade da técnica, serão abordadas com maior profundidade em um capítulo posterior deste 
trabalho, mas, para isso, devemos encontrar maior compreensão justamente sobre a questão do trauma, base sobre a qual Ferenczi erige sua clínica a partir desse momento.

\subsection{A teoria do trauma}

A teoria do trauma recebeu diversas revisões ao longo da obra de Freud. Em um primeiro momento, que remete aos primórdios da psicanálise, o austríaco se ocupou intensamente dos estudos sobre a etiologia da histeria, bem como os acontecimentos que precipitavam o adoecimento histérico. Como podemos perceber em trabalhos como Estudos sobre a histeria, de 1895, e Etiologia da histeria, de 1896, Freud considerava que a doença se originava de um acontecimento traumático real da história do indivíduo, em um plano essencialmente sexual.

Freud considerava, no entanto, que o traumatismo se constituiria a partir de dois momentos, como nos explicam Laplanche \& Pontalis:

[...] numa primeira cena, chamada de sedução, a criança sofre uma tentativa sexual por parte do adulto, sem que esta dê origem nela a qualquer excitação sexual; uma segunda cena, muitas vezes aparentemente anódina, e ocorrida depois da puberdade, vem evocar a primeira por qualquer traço associativo. É a lembrança da primeira que desencadeia um fluxo de excitações sexuais que excede as defesas do ego. Embora Freud chame traumática à primeira cena, vemos que, do estrito ponto de vista econômico, só a posteriori esse valor lhe é conferido; ou ainda: só como lembrança a primeira cena se torna a posteriori patogênica, na medida em que provoca um afluxo de excitação interna. (Laplanche \& Pontalis, 1982/2001, pp. 524-525)

Notamos, assim, que embora o trauma se constitua em dois tempos, apenas no segundo, em um momento mais avançado da vida psíquica, após a puberdade e o desenvolvimento da genitalidade, este valor é realmente conferido, a partir de uma ressignificação da situação anterior. Freud (1896/1975) recomenda aos médicos que a cena traumática deve satisfazer duas condições: a primeira, ser adequada a servir como evento determinante; e a segunda, possuir força traumática suficiente. Em sua sugestão, caso não seja possível encontrar essas características na cena que é imediatamente oferecida pelo paciente (como fica claro nos exemplos oferecidos pelo autor, em que uma descompensação histérica advém de situações triviais), deve-se ir além, em busca de uma outra cena que satisfaça essas condições. Segundo 
o autor, "Aprendemos que nenhum sintoma histérico pode emergir de uma experiência real isolada, mas que em todos os casos as lembranças de experiências mais antigas, despertadas em associação com ela, atua na causação do sintoma" (Freud, 1896/1975, p. 223). Assim se constitui, portanto, a chamada teoria da sedução, reforçada pelo caráter real do evento.

A noção de libido também é fundamental para a compreensão do conceito freudiano de trauma. Em Conferências introdutórias à psicanálise (1916-17/2014), Freud afirmaria o seguinte:

Com efeito, a expressão 'traumática' não tem outro sentido que não esse, econômico. Chamamos assim uma vivência que, em curto espaço de tempo, traz para a vida psíquica um tal incremento de estímulos que sua resolução ou elaboração não é possível de forma costumeira, disso resultando inevitavelmente perturbações duradouras no funcionamento de energia. (Freud, 1916-17/2014, p. 299)

Laplanche \& Pontalis (1982/2001) consideram o fator econômico do trauma como o principal denominador comum entre a formulação inicial da teoria da sedução e as concepções freudianas posteriores acerca do trauma. Como sabemos, Freud deixaria de considerar o trauma como um acontecimento real, passando a concebê-lo como um acontecimento imaginário - a teoria do fantasma, como nos diz Fulgêncio (2004). No entanto, a mesma ideia se manteria em relação à incapacidade do aparelho psíquico, diante do traumatismo (seja um só acontecimento violento ou o acúmulo de experiências), em liquidar as excitações surgidas, sendo portanto impossível manter o princípio de constância.

Em Além do princípio do prazer (1920/2010), Freud sugere a ideia de uma vesícula viva, representando a relação entre um organismo e seu meio. Esta vesícula seria preservada por uma camada protetora inorgânica ou por meio de páraexcitações que regulariam o afluxo dos estímulos do mundo externo. Assim, como nos explicam Laplanche \& Pontalis (1982/2001), apenas quantidades toleráveis de excitação alcançariam o sujeito, sendo possível restabelecer o funcionamento do princípio do prazer. No entanto, Freud (1920/2010) nos diz que ao mesmo tempo em que existem estímulos externos atingindo essa camada, excitações internas também vêm de dentro:

Contra o exterior existe uma proteção, as quantidades de excitação que chegam terão um efeito reduzido; em relação ao interior é impossível a proteção, as 
excitações das camadas mais profundas se propagam de forma direta e não atenuada no sistema, na medida em que determinadas características de seu curso produzem a série das sensações de prazer-desprazer. (Freud, 1920/2010, p. 140)

Essa seria, segundo o autor, a base para a projeção, a partir do momento em que se passa a tratar os estímulos internos como se fossem externos, já que resta pouca defesa contra os primeiros. Por outro lado, Freud considera que as excitações externas suficientemente fortes para romper essa membrana devem ser chamadas de traumáticas. A incapacidade em administração essa situação põe o princípio do prazer fora de ação, evocando uma compulsão à repetição que busca a descarga da excitação excedente, como seria observado nos sonhos dos neuróticos traumáticos. Percebemos então, que essa formulação compreende não apenas os fatores exógenos do trauma, mas principalmente os endógenos. Devemos salientar ainda o intenso teor pulsional da teoria freudiana do trauma, bem como seu caráter intrapsíquico - a impressão traumática parece ocorrer a partir de fatores internos, tendo em vista que os desejos poderiam precipitar essa situação. No entanto, como diria Winnicott alguns anos mais tarde:

[...] de início Freud pensou que todas as pessoas neuróticas tinham tido um trauma sexual na meninice, e mais tarde descobriu que o que elas tinham tido era desejos. Então por muitas décadas presumimos nos escritos analíticos que não existia tal coisa como traumas sexuais reais. Agora temos que admitir isso também. (Winnicott, 1963b/1983, p. 227)

Um psicanalista que buscou intensamente retomar a ideia dos traumas sexuais reais foi Ferenczi. Primeiramente, é importante destacar que a proposta ferencziana acerca da teoria do trauma possui dois aspectos. O primeiro é caracterizado por um potencial estruturante, já que é por meio da elaboração de eventos traumáticos que ocorre a constituição psíquica, noção que já vinha sendo elaborada por Ferenczi desde a primeira metade da década de 1910, em $O$ desenvolvimento do sentido de realidade e seus estágios, de 1913, e em Thalassa (1924a/2011), escrito em 1914 (embora tal formulação só viesse a público dez anos depois). Nesse trabalho, o autor determina que a catástrofe traumática da espécie a secagem dos oceanos, isto é, a passagem do meio aquático ao terrestre e aéreo seria reproduzida no nascimento do sujeito, uma catástrofe individual, no qual se perde a habitação de um meio líquido (o corpo materno). Dessa forma, segundo Lejarraga, "a ontogênese repete a filogênese" (Lejarraga, 2008, p. 118). Todavia, embora essencialmente traumático, justamente por simbolizar um abrupto corte no 
psiquismo, o nascimento possui um vasto potencial constitutivo, a partir da inserção do bebê no mundo externo, compartilhado, extrauterino. É esse importante acontecimento que permite que toda a experiência psíquica venha a ocorrer posteriormente.

Ainda a respeito da dimensão estruturante do trauma, em As fantasias provocadas (1924b/2011) Ferenczi discorre sobre o material clínico obtido a partir da estimulação conduzida pelo analista de certas ideias e afetos, de parte do paciente, de forma que o material recalcado seja mobilizado - ou seja, uma aplicação da técnica ativa. Embora relate certo sucesso clínico a partir desse tipo de atitude, é interessante destacar os ganhos que Ferenczi atribui às fantasias provocadas em uma dimensão relativa aos desenvolvimentos da teoria psicanalítica. $\mathrm{O}$ autor considera que a vivacidade da imaginação do sujeito - em outras palavras, a capacidade de fantasiar - estava ligada aos traumas sexuais infantis: "As fantasias da criança bem-educada demais encontram-se, por sua parte, sob o efeito imediato do 'recalcamento primário' (Urverdrängung), mesmo antes de se tornarem conscientes" (Ferenczi, 1924b/2011, pp. 268-269). Assim, a ausência dos acontecimentos traumáticos infantis (no caso, de caráter sexual) poderia ter como consequência uma pobreza da atividade fantasística. O autor acrescenta: "Em outras palavras, poderíamos dizer que uma certa quantidade de experiências sexuais infantis, portanto, de 'traumas sexuais', longe de prejudicar mais tarde a normalidade, sobretudo a capacidade normal de imaginação, antes a favoreceriam" (Ferenczi, 1924b/2011, p. 269). De acordo com a citação acima, portanto, evidencia-se o potencial estruturante do trauma, já que mesmo experiências sexuais traumáticas poderiam oferecer algum tipo de proteção contra os percalços que envolvem o desenvolvimento psíquico. No entanto, Ferenczi faz uma ressalva: “[...] não é aconselhável que a 'vivência' exceda um certo ótimo. Uma experiência excessiva, precoce demais ou intensa demais, pode igualmente acarretar o recalcamento e, conjuntamente, a pobreza da vida de fantasia" (1924b/2011, p. 269, grifo meu).

A proposta de que o acontecimento não exceda um certo ótimo representa um importante ponto da essência da concepção ferencziana do trauma, ao considerar que o evento adquire potencial desestruturante quando o sujeito 
encontra-se ainda despreparado (ou, poderíamos dizer, imaturo) para confrontá-lo. Ao mesmo tempo, a expressão grifada na citação acima - "experiência excessiva" - indica outra questão central para a teoria do trauma de Ferenczi, que seria aprofundada apenas em seus últimos anos de vida. Em 1930, o autor declararia o seguinte:
Após ter dado toda a atenção devida à atividade fantasística como fator patogênico, fui levado, nesses últimos tempos, a ocupar-me cada vez com maior frequência do próprio traumatismo patogênico. Verificou-se que o traumatismo é muito menos frequentemente a consequência de uma hipersensibilidade constitucional das crianças, que podem reagir de um modo neurótico até mesmo a doses de desprazer banais e inevitáveis, do que de um tratamento verdadeiramente inadequado, até cruel. (Ferenczi, 1930/2011, p. 73)
O fragmento acima evidencia a importância que Ferenczi atribui ao componente externo, o evento real, no estabelecimento da situação traumática, em contraposição à concepção econômica do trauma sugerida por Freud, uma década antes, em Além do princípio do prazer (1920/2010), segundo a qual seriam os aspectos internos o que determinaria o valor traumático do evento. Ferenczi acreditava que o trauma advém de uma situação em que é impossível desconsiderar o fator externo. Tomemos como base a seguinte definição:

\begin{abstract}
Para Ferenczi (1931), o trauma envolve sempre a incidência de um fator exógeno forte o suficiente para provocar uma modificação no aparelho psíquico, sendo que essa modificação não é necessariamente desestruturante. Ou seja, por si só o trauma não é patológico. Ele só adquire esse caráter se o fator exógeno ultrapassar certo limite, a ponto de não poder ser metabolizado e integrado ao aparelho psíquico. (Sales, 2016, p. 63)
\end{abstract}

Devemos levantar agora algumas considerações acerca dessa afirmação. Primeiramente, quanto ao fator exógeno, Sales destaca um dos principais pontos de separação entre Freud e Ferenczi. Em segundo lugar, o autor estabelece o trauma como uma experiência cuja intensidade seja tal que mobilize o psiquismo no sentido de uma alteração, seja de forma construtiva (estruturante) ou destrutiva (patogênica). O que define as consequências da experiência traumática nesse sentido é o jogo intersubjetivo, baseado tanto na intensidade do evento (que deve ser considerado de acordo com a capacidade elaborativa do indivíduo, que é o que determina o "certo limite" ao qual Sales se refere) quanto na qualidade das respostas do ambiente, isto é, como este se portará quanto à busca de reconhecimento que será conduzida pelo sujeito traumatizado - caso haja rejeição ou negação (o 
desmentido), ocorre a consolidação do trauma. Percebemos, assim, que o trauma desestruturante se desenrola a partir de dois momentos, que deverão ser investigados a seguir.

\subsubsection{A confusão de línguas e o trauma patogênico}

É possível reconhecer, a partir da obra de Ferenczi, que o trauma desestruturante tem seu alvorecer em um desencontro. Uma obscura desarmonia entre a realidade da criança e a do adulto, cujo significado vai muito além de um mero choque entre dois mundos; aquilo que o autor denomina "confusão de línguas" representa uma impactante transformação no ainda incipiente aparelho psíquico. Ferenczi atribui ao trauma (especialmente aquele do tipo sexual, em decorrência do abuso) papel fundamental na patogênese das neuroses - embora, como nos lembra Lejarraga (2008), o abuso também possa ocorrer através do castigo físico excessivo e da hipocrisia do adulto frente à criança ou, até mesmo, a partir do amor excessivo, de acordo com Peixoto Junior (2006).

Tal desencontro ocorre devido às diferenças de funcionamento psíquico e sexual entre as crianças e os adultos, representadas pela linguagem empregada pelas partes. Ferenczi (1933/2011) descreve a organização da sexualidade infantil como pertencente ao estágio do amor objetal passivo ou estágio da ternura, momento em que já existem indícios de amor objetal, mas apenas na forma de fantasia: "O prazer infantil é lúdico, funciona como um faz-de-conta que representa a compreensão que a criança pode ter da sexualidade dos mais velhos, e é nesse registro que ela interpreta as demandas do amor adulto.” (Peixoto Junior, 2006, p. 154). Segundo Ferenczi, no estágio da ternura as crianças comumente brincam com a ideia de ocupar o lugar do progenitor do mesmo sexo, no entanto, apenas em imaginação, já que não poderiam de forma alguma abrir mão da ternura materna. É importante, no entanto, esclarecer esse ponto. Poderíamos ser facilmente levados a um caminho quimérico, no qual o estágio da ternura ferencziano representaria o conflito edipiano de Freud. Não é esse o caso - o erotismo infantil, segundo Lejarraga (2005), é anterior à castração e ao recalque, “[...] sem a conotação de restrição ou inibição da concepção freudiana" (Lejarraga, 2005, p. 93). Pinheiro destaca que a ternura não exclui a sexualidade, ela apenas não se refere à modalidade genital da sexualidade: "Ternura é o que antecede a genitalidade" (Pinheiro, 2016, p. 123). As 
demandas infantis por esse amor terno possuem grande importância, por serem justamente aquilo que permite o estabelecimento e a manutenção do vínculo.

De acordo com Rentoul (2010), a linguagem da ternura está relacionada a um momento pré-edipiano, em que a sensualidade se faz presente não em um nível genital, mas de forma inocente, antes que os sentimentos advindos da culpa do adulto sejam despertados. Este autor caracteriza a vivência da ternura a partir da relação mãe-bebê da seguinte forma:

As palavras 'ternura' e 'inocência' expressam dois polos de uma relação mãebebê. Ternura é a qualidade da mãe ao cuidar e responder à inocência de uma criança; a ternura materna, correspondendo à inocência infantil antes que se aprenda a forma adulta. 'A idade terna' significa a idade da inocência, na qual a sensualidade representa a conduta física. Ternura e inocência juntas representam o ambiente da infância e da díade mãe-bebê, encapsulando totalmente o significado do uso geral de Ferenczi da palavra 'ternura'. (Rentoul, 2010, p. 38)

É importante destacar ainda que a sensualidade evocada por Rentoul nada tem a ver com uma expectativa de satisfação genital. Trata-se de uma atitude sedutora que visa à manutenção do enlace emocional e ao jogo da ternura, ou seja, um brincar sobre o que a criança imagina que seja a sexualidade adulta, como foi mencionado anteriormente. Pinheiro (2016) concorda com Rentoul ao declarar que a sedução de parte da criança ocorre em forma de brincadeira, salientando a ludicidade da sexualidade infantil. Ferenczi (1933/2011) ressalta que esse jogo pode até mesmo assumir uma forma erótica, mas mantém-se essencialmente no nível da ternura. É fundamental que o ambiente ao redor da criança atenda adequadamente essa demanda, isto é, mantendo-se na dimensão da ternura. No entanto, um grande prejuízo psíquico pode ocorrer quando o adulto interpreta mal esse tipo de situação e responde a partir de suas próprias experiências passionais, ao confundir as brincadeiras infantis com os desejos de um indivíduo sexualmente maduro. Como nos diz Ferenczi,

Em certos casos traumatizantes, o castigo atinge a criança no próprio momento de uma atividade erótica [...]. Mas a criança sente o mesmo susto se suas sensações genitais foram prematuramente forçadas, pois o que a criança deseja, de fato, mesmo no que diz respeito às coisas sexuais, é somente o jogo e a ternura, e não a manifestação violenta da paixão. (Ferenczi, 1931/2011, p. 74, grifo meu)

A linguagem da paixão, por outro lado, se refere àquela utilizada pelo adulto, que atravessou a castração e conheceu uma miríade de sentimentos, dentre 
eles um que adquire grande relevância neste tema: o sentimento de culpa. Rentoul (2010) nos revela que a palavra alemã utilizada por Ferenczi para "paixão" é Leidenschaft, que possui um significado deveras revelador:

"Leiden" significa "sofrer" [to suffer], e parece ter se transformado no significado de "paixão" [passion] em palavras inglesas equivalentes. Seu sentido revolve em torno de "paixão", "fervor", "calor". Ela surge na vida com o desenvolvimento mais avançado e pertence ao mundo do conflito neurótico, da sexualidade genital e do adulto. (Rentoul, 2010, p. 38)

Dessa forma, além de "paixão", a palavra Leidenschaft comportaria ainda a tradução para algo como "do eixo do sofrimento", conceito através do qual poderíamos vislumbrar os árduos sentimentos atrelados à expressão adulta através da linguagem da paixão. Ao menos dois deles, embora sejam identificados por nós em nossa qualidade de observadores, são irreconhecíveis para a criança. O primeiro é o ódio, o que caracteriza a ambivalência do erotismo adulto. O segundo, de imensa relevância na ideia da confusão de línguas e decorrente do primeiro, é o sentimento de culpa.

Como mencionado anteriormente, o adulto descrito por Ferenczi corresponde a alguém que atravessou a castração - reconheceu seus impulsos próprios e suas consequências. Experimentou seu ódio e sentiu a culpa decorrente de sua destrutividade. E será justamente essa culpa que deverá configurar a linguagem da paixão que entrará em choque com o mundo infantil devido à impossibilidade da criança de reconhecê-la. Ao discorrer sobre a sexualidade infantil da linguagem da ternura, Dupont recomenda: "Note que quando Ferenczi fala sobre a inocência da criança isso não significa [...] que a sexualidade infantil não existe; ele acredita que ela é desprovida de um sentimento de culpa." (Dupont, 2000, p. 22).

Segundo Ferenczi (1933/2011) é essa colisão o que dá início à situação traumática. Embora possa ocorrer de diversas formas, como o aprendizado de normas de higiene, durante o qual a criança é obrigada a submeter-se às leis do mundo externo, o autor salienta a importância do traumatismo sexual como fator patogênico - a mais extrema violência que a criança pode sofrer (Pinheiro, 2016) , o que acontece a partir desse momento da seguinte maneira: 
[...] um adulto e uma criança amam-se; a criança tem fantasias lúdicas, como desempenhar um papel maternal em relação ao adulto. $\mathrm{O}$ jogo pode assumir uma forma erótica, mas conserva-se, porém, sempre no nível da ternura. Não é o que se passa com os adultos se tiverem tendências psicopatológicas, sobretudo se seu equilíbrio ou seu autodomínio foram perturbados por qualquer infortúnio, pelo uso de estupefacientes ou de substâncias tóxicas. Confundem as brincadeiras infantis com os desejos de uma pessoa que atingiu a maturidade sexual, e deixamse arrastar para a prática de atos sexuais sem pensar nas consequências. (Ferenczi, 1933/2011, p. 116)

Aqui cabem alguns comentários acerca dessas afirmações. Primeiramente, a respeito da relação entre a criança e o adulto, vale observar que existe uma proximidade entre ambos, uma intimidade e um afeto. No mesmo texto, Ferenczi afirma que crianças, ainda que de famílias tradicionais, são frequentemente violentadas e abusadas por pessoas muito próximas, como os pais, outros parentes como avós ou tios, ou empregados da família. Devemos ressaltar que, embora Ferenczi utilize como um radical exemplo o abuso sexual, de maneira a descrever sua visão a respeito do trauma, a natureza sexual da violência não está necessariamente presente - o que é mais relevante nesse contexto é, como veremos adiante, a ausência do reconhecimento de parte do adulto da experiência compartilhada, ou seja, o desmentido.

De uma forma ou de outra, o que marca essa situação é que ela se desenvolve entre a criança e uma pessoa (ou pessoas) de confiança, palavra utilizada pelo próprio Ferenczi, o que salienta os aspectos afetivos e emocionais do trauma ferencziano. Essa ideia terá um interessante desdobramento que será retomado em um momento oportuno mais adiante neste trabalho. Por ora, convém sublinhar o fator de surpresa envolvido no caso do abuso. Pinheiro (2016) sugere que o trauma, quando dotado de qualidade desestruturante, é composto por uma violência somada ao efeito de surpresa, o que evidencia o despreparo do psiquismo para lidar com certa situação, como algo que chega cedo demais ou de forma indecifrável. Em Reflexões sobre o trauma, artigo póstumo de 1934, Ferenczi destacaria a forma súbita com que o sentimento de confiança se esfacela na ocasião do evento traumático: “A comoção psíquica sobrevém sem preparação. Teve que ser precedida pelo sentimento de estar seguro de si, no qual, em consequência dos eventos, a pessoa sentiu-se decepcionada; antes, tinha excesso de confiança em si e no mundo circundante; depois, muito pouca ou nenhuma" (Ferenczi, 1934/2011, p. 125-126, grifado no original). Ademais, o autor afirma ainda que "a subtaneidade 
da comoção psíquica causa um grande desprazer que não pode ser superado" (Ferenczi, 1934/2011, p. 126), atribuindo dois caminhos a essa superação: uma defesa aloplástica, na tentativa de transformar o mundo ao afastar-se da causa real do distúrbio; e a produção de representação de um momento posterior cuja perspectiva seja favorável, de que em um futuro o desprazer deverá cessar. Essas representações possuem uma ação anestésica, permitindo que se suporte a dor enquanto ela durar - Ferenczi oferece o exemplo da extração de um dente, que, por mais dolorosa que seja, logo haverá de terminar e tudo estará bem.

Em segundo lugar, o autor declara que, caso o adulto apresente alguma forma de distúrbio psicopatológico ou seu autodomínio tenha passado por algum tipo de infortúnio, seria impossível manter o jogo no nível da ternura. Isso levanta algumas questões segundo as quais poderíamos concluir que invariavelmente a linguagem da paixão do adulto viria a predominar, proporcionando o trauma patogênico. Poderia o trauma vivido pelo sujeito no momento em que a confusão de línguas se desenvolveu em seu próprio desenvolvimento infantil determinar a forma com que irá lidar com essa nova situação, agora que desempenha o papel de adulto passional (agressor) diante de uma outra criança? Decerto as palavras de Ferenczi parecem indicar que ocorre uma espécie de ciclo patológico em que o sujeito traumatizado na infância tende a traumatizar outras crianças, especialmente ao considerar que ocorre, nesse caso, uma identificação com o agressor - ideia que será aprofundada em breve.

Por fim, devemos destacar a última frase presente na citação anterior, a respeito da forma com que os adultos confundem as brincadeiras ternas infantis e entregam-se à passionalidade e aos atos abusivos sem considerar as consequências de suas atitudes para a criança. Peixoto Junior classifica a linguagem da paixão como uma "[...] organização libidinal caracterizada pelo agir compulsivo e pela ausência de reconhecimento da alteridade em seu âmbito subjetivo. Isso é o que faz com que um adulto seja capaz de se deixar dominar por seus desejos, impondo-os violentamente à criança." (Peixoto Junior, 2006, p. 154). A incapacidade do adulto de reconhecer a criança como alguém dotado de organização psíquica própria e distinta da sua (isto é, como sujeito) o leva a impor à criança tudo aquilo que é associado com sua passionalidade - a genitalidade, os hábitos culturais e, 
sobretudo, o sentimento de culpa. $\mathrm{O}$ adulto não reconhece a ternura da criança $\mathrm{e}$ responde a partir da linguagem da paixão. Pinheiro está de acordo, ao declarar:

$\mathrm{O}$ adulto da paixão é aquele que perde seus limites, sendo importante ressaltar que a palavra paixão, aqui, significa, sobretudo, um exagero ou abuso. Ferenczi postulou a paixão do adulto como um não reconhecimento da condição da criança; é quando o adulto toma a criança como um igual, ou seja, como outro adulto. (Pinheiro, 2016, p. 122-123, grifo meu)

A partir da citação acima, podemos introduzir uma nova dimensão à confusão de línguas: a do excesso, componente fundamental para a elaboração do conceito de trauma na teoria ferencziana. O acontecimento traumático é essencialmente excessivo para a criança - um acontecimento com o qual o imaturo aparelho psíquico ainda não está preparado para lidar. Quando o adulto invade a criança com seu erotismo passional o que acontece é um transbordamento, um desprazer tão intenso, incompreensível para a criança, o que deflagra um pernicioso efeito: "É importante ressaltar que o desprazer provocado pela comoção traumática é tão excessivo que está além do representado. [...] Não se trata simplesmente de desprazer, mas de dor, de uma 'grande dor' que não pode se inscrever no inconsciente nem ser recalcada" (Lejarraga, 2008, p. 121). Ademais, a criança, ainda desprovida de defesas, permanece imobilizada diante do adulto passional por um acentuado medo:

É difícil adivinhar quais são o comportamento e os sentimentos das crianças após a perpetração de tais atos. Seu primeiro movimento seria a recusa, o ódio, a repugnância, uma resistência violenta: 'Não, não, eu não quero, está me machucando, deixe-me!' Isto, ou algo muito semelhante, seria a reação imediata se esta não fosse inibida por um medo intenso. As crianças sentem-se física e moralmente sem defesa, sua personalidade é ainda frágil demais para poder protestar, mesmo em pensamento, contra a força e a autoridade esmagadora dos adultos que a emudecem, podendo até fazê-las perder a consciência. Mas esse medo, quando atinge seu ponto culminante, obriga-as a submeter-se automaticamente à vontade do agressor, a adivinhar o menor de seus desejos, a obedecer esquecendo-se de si mesmas, e a identificar-se totalmente com o agressor. (Ferenczi, 1933/2011, p. 117, grifado no original)

Essa identificação corresponderia a uma introjeção do agressor que, ao ser tornado intrapsíquico, desaparece da realidade externa estando, assim, sujeito ao processo primário. Ferenczi acreditava, então, que, através deste processo, a agressão deixaria de existir na realidade exterior, possibilitando à criança a manutenção do estado de ternura preexistente. Trata-se de um recurso extremo para sobreviver, uma forma razoavelmente segura de manter o vínculo com o adulto de 
maneira que se evite o desamparo - ou seja, uma defesa que implica em transformação autoplástica. Segundo Lejarraga, "a identificação com o agressor é uma estratégia de sobrevivência: como não pode 'romper' com o agressor - adulto idealizado do qual depende - a criança abre mão de suas impressões, rompendo com uma parte de si." (Lejarraga, 2008, p. 121). Todavia, Ferenczi percebe um novo problema: "Mas a mudança significativa, provocada no espírito da criança pela identificação ansiosa com o parceiro adulto, é a introjeção do sentimento de culpa do adulto: o jogo até então anódino apresenta-se agora como um ato merecedor de punição." (Ferenczi, 1933/2011, p. 117). Ao abrir mão de suas impressões, a criança absorve para si a percepção do adulto, o que inclui seu sentimento de culpa sobre aquele acontecimento. Segundo Ferenczi, o adulto adota uma atitude grosseira, perturbado pelo remorso em relação ao que acabou de ocorrer, tornando a criança ainda mais envergonhada. Ademais, o autor declara que é comum nesses casos que o adulto, tomado pela culpa, procure esvaziar o significado da situação:

Quase sempre, o agressor comporta-se como se nada tivesse acontecido e consola-se com a ideia: 'Oh, é apenas uma criança, ainda não sabe nada dessas coisas e acabará esquecendo tudo isso'. Após tal evento, não é raro ver o sedutor aderir estritamente a uma rígida moral ou a princípios religiosos, esforçando-se por meio dessa severidade em salvar a alma da criança. (Ferenczi, 1933/2011, p. 117)

Cabe, neste momento, levantar um comentário acerca da concepção da infância, da forma com que a tratamos hoje, como um fenômeno historicamente recente. Quando Ferenczi, em 1933, sugere a possibilidade de que o agressor não se importe com o que aconteceu porque se trata apenas de uma criança, que não terá lembranças do ocorrido, devemos nos recordar do desdém com que a cultura ocidental tratou as questões infantis ao longo dos séculos. Ariès (1973/1981) revela que por muito tempo a criança foi vista apenas como um sujeito em potencial e não como uma pessoa dotada de subjetividade própria. Devido aos grandes índices de mortalidade infantil, havia um notável desapego em relação à criança, algo que só começaria a mudar a partir do século XVII.

Esse desapreço se torna flagrante quando Ariès comenta o diário de Heroard, médico de Henrique IV, rei da França na virada do século XVI para XVII, no qual o autor descreve a forma como foi criado o delfim Luís XIII (que sucederia o pai no trono). São extensas as descrições de Heroard das brincadeiras sexuais 
perpetradas por todos ao seu redor - criados, familiares e os pais - desde uma idade muito precoce, antes que o menino completasse seu primeiro aniversário. Um exemplo pode ser sugerido através do fragmento a seguir, que revela algumas brincadeiras recorrentes nos primeiros anos de vida de Luís XIII:

Era uma brincadeira comum e muitas vezes repetida as pessoas lhe dizerem: 'Monsieur não tem pênis'. 'Ele respondia: É, olha aqui!, e alegremente levantavao com o dedo.' Essas brincadeiras não eram restritas à criadagem ou a jovens desmiolados ou a mulheres de costumes levianos, como a amante do Rei. A Rainha, sua mãe, também gostava dessa brincadeira: 'A Rainha, pondo a mão em seu pênis, disse: - Meu filho, peguei a sua torneira.' O trecho seguinte é ainda mais extraordinário: 'Ele e a Madame (sua irmã) foram despidos e colocados na cama junto com o Rei, onde se beijaram, gorjearam e deram muito prazer ao Rei.' (Ariès, 1973/1981, p. 76)

Ariès chama a atenção à naturalidade com que todos lidavam com essas brincadeiras, tanto de parte dos adultos como da própria criança, que tornava-se cada vez mais exibicionista. No entanto, ao completar sete anos (idade a qual acreditava-se corresponder, na época, ao encerramento de uma primeira infância), de súbito adota-se uma atitude diametralmente oposta. Os jogos sexuais eram agora intoleráveis e a criança deveria aprender boas maneiras:

O menino de 10 anos era forçado a se comportar com uma compenetração que ninguém pensava em exigir de um menino de cinco. A educação praticamente só começava depois dos sete anos. E esses escrúpulos tardios de decência também devem ser atribuídos a um início de reforma dos costumes, sinal da renovação religiosa e moral do século XVII. Era como se o valor da educação começasse apenas com a aproximação da idade adulta. (Ariès, 1973/1981, p. 77)

O autor complementa a narrativa das brincadeiras de Luís XIII com uma referência ao padre de Dainville, historiador jesuíta do século XIX, que destaca que os adultos, até o século XVI, se permitiam qualquer coisa diante das crianças, seja quanto à linguagem empregada ou suas atitudes - as crianças viam e ouviam de tudo. Ariès sugere então uma interessante provocação:

Essa ausência de reserva diante das crianças, esse hábito de associá-las a brincadeiras que giravam em torno de temas sexuais para nós é surpreendente: é fácil imaginar o que diria um psicanalista moderno sobre essa liberdade de linguagem, e mais ainda, essa audácia de gestos e esses contatos físicos. Esse psicanalista, porém, estaria errado. A atitude diante da sexualidade, e sem dúvida a própria sexualidade, variam de acordo com o meio, e, por conseguinte, segundo as épocas e mentalidades. Hoje, os contatos físicos descritos por Heroard nos pareceriam beirar a anomalia sexual e ninguém ousaria praticá-los publicamente. Ainda não era assim no início do século XVII. (Ariès, 1973/1981, p. 78) 
Devemos reservar uma ponderação sobre o psicanalista de Ariès. Decerto, nosso olhar contemporâneo contempla com grande assombro as situações pelas quais passou o então delfim. É inevitável pensarmos o abuso sexual sofrido por Luís XIII em um momento tão primitivo e ao longo de toda a sua infância. No entanto, poderíamos indagar, a partir da teoria ferencziana: seria a situação passada no século XVI descrita por Ariès traumática a um nível desestruturante? A resposta parece inalcançável - não nos cabe aqui propor uma análise sobre o caso de Luís XIII. Ainda assim, é válido refletir que o trauma vivido na confusão de línguas possui um componente vital - a culpa experienciada pelo adulto passional e transmitida à criança - que é justamente aquilo que é questionado por Ariès, quando este destaca a visão liberal a respeito da sexualidade diante das crianças em geral nessa época: "Não há por que pensar que o clima moral devesse ser diferente em outras famílias de fidalgos ou plebeus. Essa prática familiar de associar as crianças às brincadeiras sexuais dos adultos fazia parte do costume da época e não chocava o senso comum.” (Ariès, 1973/1981, p. 77)

A culpa, para a criança, possui o mesmo valor que uma nova palavra de um idioma desconhecido, não há um significado, o que gera uma grande desorientação. Pinheiro (2016) sugere que o sentimento de culpa do adulto a força a tornar-se culpada por algo que desconhece. De acordo com Ferenczi: "Se a criança se recupera de tal agressão, ficará sentindo, no entanto, uma enorme confusão; a bem dizer, já está dividida, ao mesmo tempo inocente e culpada, e sua confiança no testemunho de seus próprios sentidos está desfeita." (Ferenczi, 1933/2011, p. 117). Como a confiabilidade de sua própria percepção está abalada, a criança encontra como saída, na narrativa de Ferenczi, buscar a ajuda de um segundo adulto, de forma que este imprima algum significado àquilo que, para ela, não tem sentido.

Contudo, o que ela encontra nesse adulto é bastante diferente do esperado. Este com quem a criança se depara é alguém que, atormentado por suas próprias questões, é incapaz de suportar o relato da criança. Ao ouvir a narração do episódio de abuso (algo que por si só já demanda uma certa bravura de parte da criança), esse segundo adulto rechaça a possibilidade de que ele tenha ocorrido de fato, como se não fosse mais do que uma fantasia infantil sem importância ou apenas um fato mal compreendido pela criança: "De um modo geral, as relações com uma segunda 
pessoa de confiança - no exemplo escolhido, a mãe - não são suficientemente íntimas para que a criança possa encontrar uma ajuda junto dela; algumas tênues tentativas nesse sentido são repelidas pela mãe como tolices" (Ferenczi, 1933/2011, pp. 117-118). A mãe, no caso, escuta a criança como se ouvisse uma obra de ficção, o que serve de defesa diante do horror do fato infantil: "O adulto é mostrado como alguém que não suporta a verdade da criança. Diante do vivido infantil, o adulto nega sua veracidade. Parece que o modo do funcionamento psíquico da criança é insuportável. Assim como a criança tem dificuldade para suportar o mundo perigoso dos adultos" (Pinheiro, 2016, p. 131). Ferenczi indica que a forma com que os adultos se portam diante da criança traumatizada compõe o modo de ação psíquica do trauma: "Eles dão, em geral, e num elevado grau, prova de incompreensão aparente. A criança é punida, o que, entre outras coisas, age também sobre a criança pela enorme injustiça que representa" (Ferenczi, 1934/2011, p. 127). O autor exemplifica esse desencontro a partir da expressão húngara katonadolog, traduzida na edição brasileira como "a sorte do soldado". Todavia, ao escrever a resenha sobre um livro de Judith Pihurik que trata das consequências da Segunda Guerra Mundial na Hungria, Enikő A. Sajti (2015) nos oferece uma tradução alternativa da expressão para o inglês: “Be a man", algo como "seja homem”, ideia que encontra apoio no discurso de Ferenczi, que diz que esse dito tradicional na Hungria “[...] exige da criança um grau de heroísmo de que ela ainda não é capaz" (Ferenczi, 1934/2011, p. 127). A criança não tem a capacidade de lidar com as agruras do adulto (ou do soldado), o que inclui a linguagem passional. A expressão revela ainda todo o desprezo dispensado pelo adulto ao sofrimento da criança, como se este simplesmente deixasse de existir caso ela fosse capaz de amadurecer de súbito - o que, como podemos perceber, não ocorre de fato.

Sem o auxílio de alguém que atue como intermediador, que assessore a criança na tarefa de imprimir o significado da situação do abuso, esta torna-se incapaz até mesmo de reconhecer seu sofrimento, ficando relegada ao desamparo. Ao desqualificar e negar a dor sentida pela criança, não é apenas a intepretação desta a respeito da experiência do abuso que é colocada em dúvida, mas toda a sua forma de significar o mundo e relacionar-se com ele: "o descrédito teria o poder de tirar a certeza das próprias percepções, como se a partir daí a criança não pudesse mais confiar nos próprios sentidos" (Pinheiro, 2016, p. 140). Dessa forma, Ferenczi 
postula que não é o ato violento em si o marco da patogênese, mas a impossibilidade de sua significação - fenômeno que o autor chama de desmentido, descrito por Lejarraga da seguinte forma:

Quando na tentativa de compreender o que houve, [a criança] procura um outro adulto e a resposta é o silêncio, a negação do abuso ou a desautorização das impressões infantis, a criança não pode, com seus precários recursos psíquicos, construir uma significação para a experiência vivida. Sem a ajuda de um terceiro que possa reconhecer o sofrimento e a perplexidade infantil, que possa mediar para que o ocorrido tenha algum sentido e seja metabolizado psiquicamente, a criança fica abandonada a suas próprias forças. (Lejarraga, 2008, p. 120)

O desmentido, chamado por Pinheiro (2016) de descrédito, compõe uma segunda má surpresa vivida pela criança no evento traumático - primeiramente há $o$ ato em si, tão violento quanto inesperado, que gera um choque derivado da incompreensão da complexa linguagem passional que se apresenta diante da criança; em seguida a estranheza inerente à negação do acontecimento e do sofrimento que foi gerado. Dessa forma, constituem-se os dois tempos do trauma segundo a ótica ferencziana. No entanto, o autor destaca especialmente o impacto do segundo para a traumatogênese: "O que torna, segundo Ferenczi, o trauma traumático e patológico não é o evento em si ou a sua persistência, mas acima de tudo a negação - que se segue - por parte do adulto que a completa e a pratica" (Borgogno, 1999/2004, p. 170). Em 1931, Ferenczi afirmaria: “O pior é realmente a negação, a afirmação de que não aconteceu nada, de que não houve sofrimento ou até mesmo ser espancado e repreendido quando se manifesta a paralisia traumática do pensamento ou dos movimentos; é isso, sobretudo, o que torna o traumatismo patogênico" (Ferenczi, 1931/2011, p. 91).

Pinheiro (2016) acredita que o trauma desestruturante é necessariamente composto pelos dois tempos - caso o desmentido não ocorresse, a situação poderia tornar-se estruturante, uma vez que o ambiente daria o suporte necessário à criança. Complementando a citação anterior, Ferenczi afirma: "Tem-se mesmo a impressão de que esses choques graves são superados, sem amnésia nem sequelas neuróticas, se a mãe estiver presente, com toda a sua compreensão, sua ternura e, o que é mais raro, uma total sinceridade” (Ferenczi, 1931/2011, p. 91). Dupont está de acordo com esse pensamento, ao sugerir que

O trauma, por si só, não é necessariamente traumático; pode até, caso seja devidamente sustentado pelo ambiente, favorecer um desenvolvimento normal. 
Mas pode assim se tornar, se em um segundo momento for seguido por uma negação de parte das pessoas das quais a criança depende, principalmente a mãe. É sobretudo o efeito da surpresa, bem como a repetição de traumas, em seguida a hipocrisia, a culpa, a rejeição, a mentira, aquilo que a torna patogênica. (Dupont, 2002, p. 22)

No caso, a sustentação devida pelo ambiente corresponderia ao auxílio prestado de forma que a criança tivesse êxito ao significar o choque gerado pela linguagem passional. $\mathrm{O}$ adulto, percebido pela criança como principal referência no mundo objetivo, deveria servir-lhe de apoio na tarefa de representar as experiências que não pode compreender, sendo lhe depositada uma grande confiança que é traída quando o adulto não cumpre com sua atribuição: "o adulto tinha, para a criança, o papel fundamental de objeto suporte da introjeção, e a criança nele depositava uma 'confiança cega'. A expressão 'confiança cega' indica que, para ela, o adulto em questão representa a instância encarregada de fazer a triagem das experiências do mundo externo." (Pinheiro, 2016, p. 140). Confiança que é posta à prova pela criança ao relatar o ocorrido e que sucumbe ao encontrar a negação de parte do adulto.

A atitude adotada pelo adulto diante da criança na situação do desmentido é dotada de um valor absoluto - a criança está totalmente errada, enquanto que o adulto está com toda a razão. De acordo com Pinheiro (1996), a mera dúvida da parte do adulto que sustentasse a polissemia da situação seria o suficiente para que a inscrição fosse feita, evitando a essência desestruturante do trauma. No entanto, o que acontece é a absoluta negação do relato da criança:

[...] esse descrédito só terá valor traumático e desestruturante se o enunciado da criança for atribuído ao registro da mentira absoluta, e o enunciado do adulto ao da verdade absoluta. Ao escutar a criança, se o adulto reduz o enunciado que ouviu a um enunciado unívoco e profere, então, um descrédito também unívoco, toda a possibilidade de registro simbólico está comprometida, porque o unívoco tira o lugar da dúvida. [...] É em virtude da ambiguidade fornecida pelo adulto à criança que esta pode construir registros psíquicos e criar condições para a emergência do aparelho egoico. Se, em vez disso, o que recebe e o que fala é reduzido ao unívoco, a inscrição psíquica se torna impossível. (Pinheiro, 2016, p. 136-137)

A dor gerada pelo desmentido é tão intensa que mantém-se além do representável, sem conteúdo de representação - uma vez que o adulto não auxilia a criança na significação do evento. Ademais, o desmentido provoca uma “desarticulação do sentido e a não-inclusão de certas vivências em uma ordem 
associativa de significações" (Peixoto Junior, 2006, p. 154-155), o que quer dizer que essa dor, como nunca foi consciente, não pode ser inscrita no inconsciente ou recalcada - não há qualquer traço dela na memória, apenas reminiscências corporais sem uma correspondência mnêmica. Quando a situação traumática se desenrola dessa maneira, a elaboração do evento somente será possível posteriormente na situação analítica, a partir de um manejo clínico bastante peculiar e diferente da técnica interpretativa clássica. Como não há representação do trauma - impedindo seu recalcamento - ele não pode também ser rememorado, o que significa que a interpretação verbal é incapaz de articular esse significado.

O que Ferenczi sugere é que a liquidação do trauma deve ocorrer então a partir de sua reprodução no presente, a partir das experiências do paciente (como criança) diante de um adulto (o analista) em um contexto diferente, no qual este deve oferecer um ambiente de confiança, sem que o desmentido ocorra novamente. Trata-se da regressão ao infantil - uma repetição do trauma em um contexto diferente que oferece a possibilidade de sua elaboração. No entanto, Ferenczi salienta que essa repetição tem pouco valor por si só - o sucesso depende de uma atitude adequada de parte do ambiente analítico:

O que é fundamentalmente significativo nisso tudo é o fato de que uma ab-reação de grandes quantidades do trauma não é suficiente; a situação deve ser diferente daquela que foi realmente traumática, de forma que seja possível produzir um resultado diferente e favorável. O mais essencial aspecto da repetição modificada é a renúncia da rígida autoridade do sujeito [o analista] e da hostilidade escondida nela. O alívio que é obtido assim não é efêmero e as convicções procedentes são também mais profundamente enraizadas. (Ferenczi, 1985, p. 108).

Percebemos então que a regressão ao infantil, favorecida pela sinceridade do analista e pela confiança gerada pelo mesmo, possui grande importância para a clínica do trauma. Este tema, no entanto, será retomado e melhor desenvolvido no terceiro capítulo desta tese, explorando ainda as influências que as ideias de Ferenczi exerceram nos ricos escritos clínicos de Winnicott e Balint.

Retomando a questão do trauma na situação original, Ferenczi (1934/2011) declara que a angústia - uma grande incapacidade do sujeito para adaptar-se à situação de desprazer - surge como consequência imediata do choque traumático, exigindo uma defesa desesperada que o afaste da situação hostil. A autodestruição - outra tentativa de transformação autoplástica - surgiria como uma 
válvula de escape, uma fuga viável, aniquilando, dessa forma, a consciência: "O mais fácil de destruir em nós é a consciência, a coesão das formações psíquicas numa entidade: é assim que nasce a desorientação psíquica" (Ferenczi, 1934/2011, p. 127, grifado no original). Daí os frequentes casos de desmaios em virtude de eventos traumáticos. A percepção do mal é suspensa pela desorientação psíquica, devendo-se recordar que a própria percepção da realidade foi posta em suspeição a partir do momento em que o adulto desacreditou a narração da criança sobre a situação traumática - como já não restara muito valor à percepção da criança, poderse-ia facilmente abrir mão dela.

Essa dor insuportável poderia ser vista como a experiência mais próxima da morte sem que se faça presente uma razão concreta, física. Diante da grande dor sofrida, só resta à criança abrir mão de uma importante parte de si - devemos nos lembrar de que o ponto de vista da criança e o modo com que ela significa o mundo encontram-se totalmente comprometidos na medida em que não encontram validade no mundo real, e a identificação com o agressor é uma das principais estratégias de sobrevivência nesse momento. Um outro fenômeno acompanha esse acontecimento, através do qual a criança vê-se obrigada a um repentino e compulsório amadurecimento, alheio à sua própria temporalidade, chamado por Ferenczi (1933/2011) de progressão traumática.

\subsubsection{A progressão traumática}

Nesse distorcido processo de amadurecimento, a criança comporta-se como um adulto, formado de maneira tão precoce quanto instável: “A criança que sofreu uma agressão sexual pode, de súbito, sob a pressão da urgência traumática, manifestar todas as emoções de um adulto maduro, as faculdades potenciais para o casamento, a paternidade, a maternidade, faculdades virtualmente pré-formadas nela" (Ferenczi, 1933/2011, p. 119). A bela metáfora usada por Ferenczi para ilustrar essa situação remete a um fruto que amadurece depressa demais ao ser bicado por um pássaro, logo apodrecendo. Além disso, esse amadurecimento precoce retoma a exigência do adulto discutida anteriormente (katonadolog), agora de forma efetiva. 
O autor destaca que esse súbito amadurecimento emocional pode ser acompanhado de um processo análogo em um plano intelectual, ao retomar a ideia do bebê sábio, sugerido em um curto texto anterior, O sonho do bebê sábio (1924c). Tal sonho corresponde a uma fantasia recorrente, na qual um bebê ainda recémnascido subitamente se mostra capaz de falar e exibir sua sabedoria à família, oferecendo sábios conselhos aos adultos. A partir do texto de Ferenczi, Bokanowski (2000/2000) destaca quatro níveis de interpretação sugeridos a esse sonho: a) uma ironia referente ao grande interesse geral da psicanálise pela primeira infância, estágio que abrigaria tudo que há de mais relevante no sujeito; b) o desejo de afirmar a superioridade do infantil sobre o adulto; c) o desejo de melhor servir-se da posição de bebê, criando condições para relacionar-se sexualmente com sua nutriz; d) o desejo de tomar posse de um saber que foi perdido na infância. Podemos perceber um viés claramente pulsional nas justificativas encontradas por Ferenczi em 1924, segundo as quais o sonho do bebê sábio representa uma tentativa de satisfação de desejos infantis não realizados. No entanto, o bebê sábio descrito por Ferenczi em seus últimos trabalhos se mostra bastante diferente. Como nos diz Bokanowski, não se trata mais de uma criança pulsional que se desenvolveu como um adulto neurótico, mas de

[...] uma criança traumatizada e narcisicamente atingida na unidade de sua personalidade, que se tornou um adulto clivado em virtude da marca de seu trauma, cuja origem situa-se, para Ferenczi, na confusão entre a linguagem da ternura, apanágio da linguagem da criança, e a linguagem da paixão que é a linguagem dos adultos. (Bokanowski, 2000/2000, p. 93, grifo meu)

Devo destacar que a própria imagem do bebê sábio possui grande relevância quando tomamos a teoria ferencziana do trauma como ponto de partida. Ferenczi nos mostra que, embora utilize a agressão sexual como representação para o trauma (a mais intensa violência que a criança poderia sofrer), este ocorre em diferentes dimensões, como no aprendizado de regras de higiene (conforme mencionado anteriormente) ou do próprio idioma da família. O que está em questão é a apresentação forçada de uma nova configuração, uma linguagem que é alheia à criança. A ideia de uma criança recém-nascida, claramente incapaz de falar, que subitamente torna-se apta a se comunicar com desenvoltura e sabedoria na língua 
em questão representa com muita nitidez a forma com que Ferenczi descreve a introjeção do agressor e sua linguagem da paixão. A criança renuncia à linguagem da ternura, precocemente apossando-se da linguagem passional.

Ao desvelar novamente o sonho do bebê sábio já nos anos 30, Ferenczi nos indica a atitude que a criança percebe como a estratégia mais adequada que deve adotar de modo a garantir sua sobrevivência - o desenvolvimento da capacidade de cuidar de si mesma. A confiança outrora depositada nos adultos não mais se sustenta. A criança encontra-se abandonada à própria sorte, devendo responsabilizar-se por seus próprios cuidados. Ao negar à criança a possibilidade de simbolização do trauma através da negação e da reprimenda do discurso infantil, o adulto é percebido como alguém fora de controle, enfurecido: "o medo diante de adultos enfurecidos, de certo modo loucos, transforma por assim dizer a criança em psiquiatra; para proteger-se do perigo que representam os adultos sem controle, ela deve, em primeiro lugar, saber identificar-se por completo com eles" (Ferenczi, 1933/2011, p. 120, grifo meu). A forma com que o autor descreve os adultos, "de certo modo loucos", encontra um significativo amparo na língua inglesa. Tomemos como exemplo a situação a seguir. Uma criança é flagrada cometendo uma travessura na escola. Como de costume, ao conversar com a criança, uma professora lhe diz que deve falar a respeito do que aconteceu com seus pais. Já conhecendo a forma com que seus pais lidam com ela, a criança se atemoriza, e pede à professora que não diga nada. Quando a professora lhe pergunta por que não, a criança, em inglês, lhe responde: "Dad will be mad at me". Em uma tradução literal seria algo como "papai vai ficar louco comigo". É comum, na língua inglesa, utilizar essa expressão ao dizer que um adulto vai ficar com raiva e dar uma bronca em uma criança, o que encontra ressonância na teoria de Ferenczi. Parece não se tratar de uma ação pontual - dar a bronca - mas de provocar uma mudança de estado no adulto que repercutirá em sua relação com a criança, algo de relevante impacto para ela.

Ademais, o autor destaca que a loucura desses adultos exige um cuidado. A criança precisa proteger-se desse entorno potencialmente hostil, e para isso ocorre a identificação com o adulto agressor, como discutido anteriormente, revelada através do amadurecimento precoce de uma parte da personalidade. 
Pinheiro descreve o bebê sábio da seguinte forma: "A criança que identifica-se com o agressor torna-se abruptamente um adulto e é capaz de cuidar de sua família como se fosse um verdadeiro assistente psiquiátrico" (Pinheiro, 2016, p. 74). A emergência do bebê sábio, responsável pelo cuidado de si e dos outros ao seu redor, cobra um alto preço ao sujeito: a renúncia ao eu infantil e suas demandas de ternura. Segundo Lejarraga,

Ante ao pavor ocasionado pelo trauma, a criança vê-se obrigada a lançar mão de uma defesa mais radical que o recalque, nomeada por Ferenczi de 'autoclivagem narcísica'. A identificação com o agressor é uma parte indissociável dessa clivagem, já que, enquanto um fragmento egoico é ocupado violentamente pelo agressor, tornando-se culpado e artificialmente amadurecido, o outro fragmento egóico fica oculto ou destruído. (Lejarraga, 2008, p. 122)

O eu infantil, seja oculto ou destruído, torna-se portanto ausente, isolado, como consequência da clivagem narcísica. Bokanowski o descreve como "[...] uma parte 'sensível brutalmente destruída' [...]” (Bokanowski, 2000/2000, p. 95). Diante do choque traumático, as frustradas demandas de ternura são postas em suspensão, enquanto que uma psique artificial, “[...] que sabe tudo mas nada sente [...]" (Bokanowski, 2000/2000, p. 95), e organizada de acordo com a introjeção do agressor, assume o controle - porção esta que acaba por responsabilizar-se pela sobrevivência do sujeito traumatizado. De acordo com Pinheiro,

[...] a descrição ferencziana da identificação com o agressor propõe a imagem de uma invasão no eu da criança. O agressor usurpa o espaço egoico e toma posse desse lugar, como se assumisse a fala da criança ou ocupasse seu espaço psíquico. A paixão toma a palavra e separa-se da ternura, sem que qualquer contato entre elas seja possível, como se uma desconhecesse a existência da outra. [...] Assim, o agressor nos textos de Ferenczi é o posseiro do eu, ignorando o seu verdadeiro dono. (Pinheiro, 2016, p. 143)

Assim, ainda que a um alto preço - a atomização da vida psíquica - o sujeito consegue garantir sua sobrevivência diante do trauma desestruturante. Isto somente ocorre graças à ação daquilo que Ferenczi chama de forças órficas, “[...] instintos vitais organizadores que ajudam a criança a sobreviver à catástrofe traumática” (Lejarraga, 2008, p. 122). Nas notas de 12 de janeiro de 1932 do Diário Clínico, Ferenczi desenvolve essa noção ao narrar o caso de clínico de uma paciente, designada R.N. e também chamada pelo autor de Orpha.

De acordo com os relatos de Ferenczi, R.N. sofreu três momentos de violência sexual. O primeiro ocorreu quando ela tinha um ano e meio de idade, 
quando um parente próximo adulto prometeu-lhe dar 'algo bom' e, ao invés, a drogou e abusou sexualmente dela, o que evocou-lhe um sentimento de desilusão e desamparo, bem como de incapacidade de realizar sua própria vontade. Ferenczi sugere que, concomitantemente a um provável desejo inconsciente de não estar viva, a jovem R.N. manteve sua existência habitual, ou seja, desenvolvendo uma "[...] vida dupla artificial, junto com uma completa repressão de suas próprias inclinações e seus sentimentos" (Ferenczi, 1985, p. 8). Aos cinco anos, R.N. sofreu um novo e brutal ataque: “[...] genitais artificialmente dilatados, insistente sugestão para ser permissiva com homens; administração de estimulantes intoxicantes" (Ferenczi, 1985, p. 8). O autor indica que, embora o sofrimento envolvido fosse imenso e as tendências suicidas se intensificassem, nesse momento as forças órficas entravam em ação:

A imensidão do sofrimento, somado ao desamparo e a desesperança quanto a qualquer ajuda externa, a impulsionaram em direção à morte; mas enquanto a consciência se imaginava perdida ou abandonada, os instintos vitais organizadores ("Orpha") despertaram, e no lugar da morte, permitiram que a insanidade interviesse. (As mesmas forças órficas pareciam já estar presentes no momento do primeiro choque). (Ferenczi, 1985, p. 8)

Como resultado, a atomização da personalidade de R.N. se aprofunda, sendo percebida agora por Ferenczi através de três fragmentos. O primeiro, uma parte que sofre psiquicamente no inconsciente que corresponde à criança seduzida, dormente, de quem o ego desperto nada sabe a respeito. Pode ser alcançada pelo analista somente com grande dificuldade, revelando-se em sono ou transe profundo. O segundo, Orpha, uma psique que preza pela preservação da vida custe o que custar: "Este fragmento desempenha o papel de um anjo da guarda; produz alucinações realizadoras de desejos, fantasias consoladoras; anestesia a consciência e a sensibilidade sobre sensações à medida em que elas se tornam insuportáveis" (Ferenczi, 1985, p. 9). No momento do segundo ataque sofrido por R.N., a forma encontrada por essa instância de garantir a sobrevivência foi extrair completamente a vida psíquica do tão sofrido corpo, sendo este o terceiro fragmento descrito por Ferenczi. O corpo é deixado então como uma casca vazia, sem substância, o que 
deixa ao sujeito uma percepção de que o evento ocorreu a uma outra pessoa ou como se tivesse sido observado de fora do corpo ${ }^{1}$.

Após esses eventos, R.N. conseguiu alcançar algum equilíbrio, ainda que precário. No entanto, aos onze anos e meio, sofreu um terceiro e perene ataque um abandono súbito de parte do abusador:

Ser privada de toda espontaneidade tornou impossível para a criança qualquer ajuste razoável ou antecipação positiva de novas possibilidades. A situação foi piorada pelo fato de que o pai, antes da separação, como um tipo de despedida, xingou a criança, e, portanto, usou sua influência ao máximo para tornar a criança indelevelmente consciente de sua própria imundície, inutilidade e repugnância. A incansável Orpha, aqui, não poderia mais se ajudar; acabou por encorajar o suicídio. Mas, como isso se fez impossível, a única forma de existência ainda disponível era uma completa atomização da vida psíquica. (Total insanidade, estupor catatônico alternado com terror, alucinações e a confusão de impressões mnêmicas do passado caoticamente misturadas). (Ferenczi, 1985, p. 10)

De acordo com o autor, R.N. conseguiu manter-se viva, ainda que fragilmente, graças à criação de um psiquismo artificial que manteve-se habitando um corpo ainda vivo apenas de forma forçada. Os efeitos das clivagens são descritos por Ferenczi a partir das partes que podem ser identificadas após o terceiro choque sofrido por R.N.:

(a) Superficialmente, um ser humano ativo, capaz, com um mecanismo precisamente - talvez um pouco preciso demais - regulado; (b) por trás dele, um ser que nada mais quer saber da vida; (c) por trás desse eu assassinado, as cinzas dos sofrimentos mentais anteriores, que são acesos toda noite pelas chamas do sofrimento; (d) a doença em si como uma massa separada de afeto, sem conteúdo e inconsciente, os restos da pessoa em si. (Ferenczi, 1985, p. 10)

É importante destacar que as clivagens sofridas por R.N. evidenciam a afirmação de Ferenczi de que 'O 'choque' é equivalente à aniquilação do sentimento de si, da capacidade de resistir, agir e pensar com vistas à defesa do Si mesmo" (Ferenczi, 1934/2011, p. 125). A defesa está sempre presente em algum nível, não importa o quão débil: “[...] abandonar sem resistência é, mesmo no nível da representação, inaceitável. Vemos também que, na natureza, mesmo o ser mais fraco opõe uma certa resistência (até a minhoca se empina)" (Ferenczi, 1934/2011, p. 126). No entanto, a defesa se prova ineficaz diante do evento traumático - resta

\footnotetext{
${ }^{1}$ Essa ideia de Ferenczi apresenta muitas semelhanças com os fenômenos de despersonalização descritos por Winnicott, relação que será desenvolvida adiante nesse trabalho.
} 
apenas a aceitação do trauma, enquanto o sujeito sobrevive destituído de sua forma própria, modelável como um saco de farinha.

Percebemos, nesse momento, que a descrição da clivagem narcísica segundo Ferenczi possui grandes semelhanças com o conceito de falso self desenvolvido por Winnicott, como nos lembra Bokanowski (2000), que encontra como elo entre as duas teorias a desqualificação dos sentimentos e do vivido. Da mesma maneira, podemos perceber muitos pontos em comum sobre a postura do analista diante desses casos de acordo tanto com Winnicott quanto com Ferenczi, especialmente ao considerar o reduzido valor terapêutico da interpretação nesses casos. Todavia, esse assunto será mais bem desenvolvido nos próximos capítulos. 


\section{O trauma segundo Balint e Winnicott}

Embora as formulações de Ferenczi tenham sido por muito tempo marginalizadas no meio psicanalítico, principalmente após sua grave ruptura com Freud e a partir das controvérsias geradas pela técnica da análise mútua, é notável como as inovadoras modificações clínicas promovidas pelo autor foram levadas adiante pelas futuras gerações de psicanalistas, através de referências diretas ou indiretas à sua obra. Durante os anos que se seguiram à sua morte, poucos psicanalistas se mostraram dispostos a examinar os conceitos ferenczianos - um deles era Michael Balint.

Balint, húngaro como Ferenczi, é considerado o principal herdeiro da teoria ferencziana (Peixoto Junior, 2013). Tendo desenvolvido a maior parte de sua clínica na Inglaterra, para onde se mudara em 1938, primou pela tradução e divulgação das ideias de Ferenczi na Sociedade Britânica de Psicanálise, da qual se tornaria presidente em 1968. A reverência de Balint a Ferenczi fica clara, por exemplo, na nota que escreveu quando do falecimento de seu mestre (Balint, 1933a), revelando a fundamentação clínica que basearia posteriormente todo o curso de suas próprias ideias. Balint desenvolveria então um pensamento teórico e uma clínica psicanalítica de imensa riqueza para a compreensão de fenômenos precoces por intermédio do estudo das relações objetais, como perceberemos ao longo deste capítulo.

Donald Winnicott, por outro lado, manifesta uma construção teóricoclínica que também se afasta das concepções freudianas, mas, ao contrário de Balint, não se filia a Ferenczi - ao menos, não explicitamente. Alguns autores, como Figueiredo (2002) e Lejarraga (2008), percebem muitos pontos em comum entre o inglês e Ferenczi, embora raramente encontremos alguma referência direta à obra ferencziana da parte de Winnicott ao longo de seus escritos. A partir de um ponto de vista kleiniano, a princípio, e assumidamente independente logo em seguida, Winnicott promove uma investigação extremamente apurada sobre os eventos que ocorrem em uma dinâmica primitiva, não edípica. Dessa forma, sua contribuições sobre a noção de trauma primitivo e as resultantes agonias impensáveis serão de 
grande valor para a regressão no ambiente analítico, como perceberemos em seguida.

\subsection{Balint - do amor primário à falha básica}

Ao longo da obra de Michael Balint, é possível notar uma tendência fortemente contestadora. Mesmo quanto a psicanalistas destacados pelo autor como influências, como Sigmund Freud ou Melanie Klein, Balint sempre deixou claro o quão contrário seu posicionamento se constituía em relação a eles. Pode-se considerar que apenas a obra de Sándor Ferenczi, principal referência teórica de Balint, foi adotada pelo autor com maior propriedade.

Um exemplo da discordância de Balint em relação aos modelos teóricos anteriores constituiu-se como uma de suas principais contribuições à psicanálise: ao rejeitar a noção de narcisismo primário, que teria sido equivocadamente trabalhada pelas escolas vienense e londrina segundo sua ótica, Balint (1937) propõe a hipótese de um amor objetal primário, um estado primitivo que serve de base para todas as relações com os objetos que o sujeito estabelece posteriormente, noção que terá grande importância para melhor compreendermos a concepção do autor sobre a traumatogênese.

\subsubsection{Amor primário e narcisismo primário}

O amor primário é descrito por Balint como um estado pré-objetal, sem qualquer tipo de ansiedade ou relação de objeto - existem apenas as substâncias e as expansões amistosas. De acordo com sua teoria (1959), o objeto pode ter dois significados. O primeiro pode ser identificado como uma natureza de "alvo", algo que atrai a direção da ação, o que se aproximaria ao que Freud havia postulado em 1905:

Em seus Três ensaios sobre a teoria da sexualidade, ele tentou organizar o campo dos instintos sexuais, usando três critérios para classificá-los. Esses são o alvo, o objeto e a fonte de um instinto. A fonte é a parte do corpo do qual se sente que a urgência pulsional se origina; o alvo é o ato ao qual a pulsão se dirige; e, por fim, o objeto é a parte do mundo externo, normalmente uma pessoa, ou do corpo do próprio sujeito, do qual a atração sexual procede. (Balint, 1959, p. 60) 
Outro significado seria o de um obstáculo no caminho da ação, do qual se precisa desviar. Assim, os objetos poderiam ser definidos como "[...] algo firme, de contorno nítido e resistente" (Balint, 1959, p.60). Já a substância representa um préobjeto com delimitação em gradientes, ou seja, sem definição clara dos limites entre ela mesma e o sujeito. A substância proporciona uma relação tranquila, não se constitui como uma barreira para o indivíduo, o que permite as expansões amistosas, o flutuar seguro do ser e uma confluência psíquica harmoniosa com o ambiente. É esse tipo de relação que caracteriza o amor primário.

Por outro lado, Balint (1937) caracteriza o narcisismo primário como uma noção carregada de significado, de imensa relevância para o pensamento psicanalítico, e, ao mesmo tempo, muito pobre - a aceitação dessa ideia não permitiria qualquer possibilidade de relação mais primitiva com objetos externos. $\mathrm{O}$ autor descreve o início da vida mental extrauterina sob a hipótese do narcisismo primário da seguinte forma:

[...] a criança ainda não tem conhecimento do mundo externo, ainda nem ao menos o percebe; subjetivamente ela não tem qualquer relação com os objetos ou pessoas de seu ambiente e, consequentemente, nenhum desejo orientado em direção ao mundo; ela experimenta apenas o aumento e desaparecimento de suas necessidades, mas ainda não se conecta com o mundo externo; os fenômenos emocionais observáveis, como chorar, choramingar, coçar, agarrar e incomodar, de um lado, sorrir e tranquilidade de outro, são meramente ab-reações; como a criança ainda não percebe qualquer objeto externo ela ainda não pode estabelecer relações objetais libidinais; de sua libido nada ainda foi voltado para fora. (Balint, 1937, p.103)

Tal concepção de narcisismo primário expressaria, portanto, que logo após o nascimento o sujeito é incapaz de sequer reconhecer a existência do mundo externo, dificultando ou até mesmo impossibilitando que se estabeleça qualquer tipo de relação com o entorno.

Balint (1969) descreve três perspectivas freudianas sobre as primeiras relações com o ambiente - as quais Stewart (1996) classifica, respectivamente, como relação objetal primária, autoerotismo primário e narcisismo primário. A mais antiga remete, novamente a 1905, quando Freud - na seção “A descoberta do objeto", última parte do terceiro dos Três ensaios sobre a teoria da sexualidadesugere que o objeto seria localizado, ao menos a princípio, no mundo externo: 
Quando a primeiríssima satisfação sexual ainda é vinculada à ingestão do alimento, o instinto sexual tem um objeto fora do próprio corpo, no seio da mãe. Ele o perde somente depois, talvez justamente na época em que se torna possível, para a criança, formar uma ideia total da pessoa a quem pertence o órgão que lhe traz satisfação. Então o instinto sexual se torna, por via de regra, autoerótico, e somente após a superação do período de latência é restabelecida a relação original. Não é sem boas razões que a criança a mamar no seio da mãe se tornou o modelo de toda relação amorosa. A descoberta do objeto é, na verdade, uma redescoberta. (Freud, 1905/2016, pp. 142-143)

Neste contexto seria a perda do objeto que tornaria a pulsão autoerótica, deixando margem para uma tendência à restauração da situação original, a modalidade primitiva de relação objetal que se constitui então como matriz para toda relação amorosa posterior. Por outro lado, Freud acrescentou em 1915 uma nota de rodapé (após, devemos lembrar, a publicação de Introdução ao narcisismo, de 1914) através da qual sugere que um segundo caminho para o encontro com o objeto seria de modalidade narcísica, “[...] que busca o próprio Eu e o reencontra no outro.” (Freud, 1905/2016, p. 143). Peixoto Junior sugere então que “[...] a hipótese de Balint é a de que mesmo após a introdução da teoria do narcisismo, por muitos anos, Freud não teria tido a intenção de abandonar a tese de uma relação objetal precoce primária em benefício do conceito de narcisismo primário" (Peixoto Junior, 2013, p. 20).

A segunda concepção de Freud sobre as relações primitivas seria encontrada justamente no artigo de 1914 sobre o narcisismo. No referido trabalho, o autor austríaco se vale de uma descrição da megalomania - “[...] uma superestimação do poder de seus desejos e atos psíquicos, a 'onipotência dos pensamentos', uma crença na força mágica das palavras, uma técnica de lidar com o mundo externo, a 'magia', que aparece como aplicação coerente dessas grandiosas premissas" (Freud, 1914/2010, pp. 11-12) - para representar, analogamente, uma atitude primordial das crianças diante do mundo externo. $\mathrm{O}$ autor argumenta que a megalomania não constitui um estado novo, mas seria apenas a exacerbação de um estado que já existira antes à custa da libido objetal. A partir dessa ideia, Freud sugere: "Formamos assim a ideia de um originário investimento libidinal do Eu, de que algo é depois cedido aos objetos, mas que persiste fundamentalmente, relacionando-se aos investimentos de objeto como o corpo de uma ameba aos pseudópodes que dele avançam" (Freud, 1914/2010, p. 12, grifo meu). Dessa forma 
compreendemos um novo postulado freudiano, segundo o qual o autoerotismo constitui um estágio inicial da libido, a qual apenas posteriormente seria disponibilizada para o mundo externo.

Outra importante questão levantada por Freud em 1914 concerne ao desenvolvimento da estrutura egoica. De acordo com o autor, “[...] é uma suposição necessária, a de que uma unidade comparável ao Eu não existe desde o começo no indivíduo; o Eu tem que ser desenvolvido. Mas os instintos autoeróticos são primordiais; então deve haver algo que se acrescenta ao autoerotismo, uma nova ação psíquica, para que se forme o narcisismo" (Freud, 1914/2010, p. 13). Essa passagem revela o caráter secundário do narcisismo, descrito por Freud nesse momento como uma experiência situada entre o autoerotismo original e as futuras relações de objeto. Balint (1969) destacaria posteriormente seu desapontamento com a falta de uma descrição mais clara a respeito dos aspectos primários do narcisismo, justamente no trabalho em que Freud apresenta esse conceito.

O terceiro dos entendimentos de Freud a respeito do narcisismo primário destacados por Balint foi explanado no inacabado Esboço de psicanálise, escrito entre 1938 e 1939. Balint (1969) ressalta que, provavelmente por representar sua última posição sobre esse assunto, esta descrição do narcisismo primário é a mais aceita e difundida entre a comunidade psicanalítica. Nesse momento, Freud sugere o seguinte:

É difícil dizer algo do comportamento da libido no id e no superego. Tudo o que sabemos sobre ele relaciona-se com o ego, no qual, a princípio, toda a cota disponível de libido é armazenada. Chamamos a este estado absoluto de narcisismo primário. Ele perdura até o ego começar a catexizar as ideias dos objetos com a libido, a transformar a libido narcísica em libido objetal. (Freud, 1939/1975, p. 176, grifado no original)

No entanto, mesmo anteriormente à publicação do Esboço de psicanálise, Balint já deixava clara sua insatisfação com a ideia de um narcisismo primário que caracterizaria o princípio da vida psíquica. O autor levantaria, em 1937, duas objeções à noção de narcisismo primário. Primeiro, ele possui características negativas marcantes - o repetido uso do advérbio "ainda" na sua descrição não é ocasional (o indivíduo ainda não se relaciona com o mundo externo, a criança ainda não percebe seu entorno). Ele representa como seu retrato é pincelado a partir de características que o sujeito não possui, podendo ser considerado uma dedução, uma 
extrapolação teórica de Freud baseada no observável narcisismo secundário, devido à falta de evidência clínica que a suporte. Uma segunda crítica se refere aos argumentos de Freud ligando o narcisismo primário aos catatônicos e aos recémnascidos. Balint afirma que não há catatônico que seja absolutamente não responsivo; com perseverança é possível suscitar uma relação objetal apropriada (o mesmo se provaria com o bebê recém-nascido).

Por outro lado, Balint identifica certa similaridade entre o cenário primitivo infantil e a situação analítica. Segundo o autor (1937), a união com o objeto seria o objetivo máximo dos instintos, tendo por consequência a recuperação da identidade ego-objeto, da harmonia que havia com o ambiente durante o amor primário (1969). No adulto, isto seria proximamente alcançado através do orgasmo, situação em que existe uma certa ausência da noção de realidade em relação ao parceiro. O mesmo poderia ocorrer quanto ao analista, no sentido em que ele é tratado pelo paciente como se seus desejos confluíssem, embora sua existência nunca fosse contestada. $\mathrm{O}$ autor declara que seria possível presumir o mesmo tipo primitivo de amor na criança, apoiando-se nos estudos de A. Balint, I. Hermann, além de suas próprias observações.

Assim, Balint (1937) sugere o amor objetal primário como o momento mais arcaico da existência no qual o indivíduo encontra-se em um estado de paz e harmonia com o entorno. Durante esse período se desenvolve a primeira de todas as relações (com o objeto mãe), a princípio indiferenciada, à qual remetem todas as relações objetais posteriores. Estas ideias o distanciavam do pensamento kleiniano, uma vez que é o amor que constitui o fato primitivo e não o ódio - este seria secundário e derivado das experiências de frustração e separação. O sadismo e o masoquismo ainda seriam, portanto, comportados pela teoria balintiana, mas assumiriam um caráter secundário. As atitudes tomadas pelo sujeito seriam conduzidas por uma tentativa de reestabelecer a situação harmônica anterior. De acordo com Peixoto Junior: "Todos os esforços humanos visam estabelecer ou restabelecer uma harmonia envolvente com o entorno, visando amar em paz. Sadismo e ódio parecem, portanto, inúteis e incompatíveis com esse desejo, ainda que a agressividade ou a violência possam ser utilizadas em momentos que 
precedem imediatamente esse estado de harmonia desejada" (Peixoto Junior, 2013, p. 29).

Segundo Balint, o amor primário ocorre em um momento bastante primitivo da vida e não está ligado a qualquer zona erógena. A base biológica desta relação objetal primitiva se constitui sob a interdependência pulsional da mãe com o bebê, uma sintonia entre as partes - através da qual uma satisfaz a outra sem a expectativa de uma recompensa - derivada das experiências da vida intrauterina e da intensa catexia da parte do feto em relação ao ambiente pré-natal:

Esse ambiente, no entanto, é provavelmente indiferenciado; por um lado, ainda não existem objetos nele; por outro, dificilmente possui qualquer tipo de estrutura, em particular, nenhum contorno nítido em relação ao indivíduo; ambiente e indivíduo penetram um ao outro, eles existem juntos em uma 'mistura harmoniosa'. (Balint, 1969, p. 66)

Balint exemplifica a mistura harmoniosa interpenetrante a que se refere a partir da situação de um peixe no oceano - é difícil determinar se a água em sua boca e guelras faz parte do peixe ou do oceano, da mesma forma que mãe e feto se confundem. $\mathrm{O}$ ar que nos circunda desempenharia um papel semelhante, fazendose presente como substância:

Usamos o ar, na verdade não podemos viver sem ele; nós o inalamos para tirar certas partes que usamos da maneira que queremos; então, após nele colocar as substâncias das quais queremos nos livrar, o exalamos - sem prestar qualquer atenção a isso. Na realidade, $o$ ar deve estar presente para nós e, enquanto houver suprimento e qualidade suficiente, nós não o notamos. Esse tipo de ambiente deve simplesmente estar lá e, enquanto estiver - por exemplo, se conseguirmos ar suficiente - tomamos sua existência como certa, não o consideramos um objeto, ou seja, separado de nós; apenas o usamos. Essa situação muda abruptamente se o ambiente é alterado - se, por exemplo, no caso do adulto, o suprimento de ar sofra uma interferência - então o ambiente aparentemente não-catexizado ganha imensa importância, isto é, sua verdadeira catexia latente torna-se aparente. (Balint, 1969, pp. 66-67)

Segundo o autor (1969), essa mistura harmoniosa interpenetrante é perturbada cedo demais, quando o ambiente passa por uma alteração, o que força uma nova forma de adaptação que inicia a separação entre indivíduo e ambiente. $\mathrm{O}$ primeiro momento traumático, como nos diz Balint, seria justamente o nascimento, quando ocorre uma radical mudança na qualidade do ambiente:

Objetos, incluindo o ego, começam a emergir da mistura de substâncias e da quebra da harmonia das expansões sem limites. Os objetos possuem - em contraste com as mais amistosas substâncias - contornos firmes e limites 
definidos os quais devem ser reconhecidos e respeitados. A libido não está mais em um fluxo homogêneo do id e do ambiente; sob a influência dos objetos emergentes, concentrações e rarefações aparecem no fluxo. (Balint, 1969, p.67)

Este novo mundo então descoberto pela criança, povoado por objetos bem delimitados, acaba por fomentar um reinvestimento da libido no ego na tentativa da recuperação da sensação de unidade presente anteriormente. Balint (1969) dá a entender que essa parte da libido é definitivamente de natureza narcísica, mas de qualidade secundária em relação à catexização original do ambiente. $\mathrm{O}$ autor lista então quatro tipos de investimentos libidinais que poderiam ser observados na infância mais longínqua:

(a) Reminiscências do investimento original no ambiente transferidas para os objetos emergentes; (b) outras reminiscências do investimento original no entorno retiradas para o ego como confortadores secundários contra a frustração, isto é, catexias narcísicas e autoeróticas; (c) recatexias que emanam do narcisisimo secundário do ego. Em acréscimo a essas três formas bastante estudadas de catexias há uma quarta que resulta no desenvolvimento das estruturas ocnofílicas e filobáticas do mundo. (Balint, 1969, pp. 67-68)

Assim, podemos perceber diferenças capitais entre a ideia clássica de narcisismo primário e a concepção de Balint sobre o amor primário. Enquanto o primeiro presume uma ausência total de qualquer tipo de relação objetal e completa desconsideração do mundo externo, Balint sugere, através do conceito de amor primário, que, embora o sujeito se encontre em um meio razoavelmente indiferenciado, como consequência da vida anterior ao nascimento, há certeza da existência do mundo externo. De fato, no contexto do amor primário, torna-se até mesmo irrelevante pensar em uma diferenciação entre mundo interno e externo mãe e bebê encontram-se tão adaptados um ao outro que suas necessidades e desejos confluem, existe uma perfeita harmonia na qual ambos se interpenetram, tal qual o ar que nos envolve e inunda nossos pulmões. $\mathrm{O}$ ambiente é percebido então como substância, sem contornos definidos, cujos limites são predominantemente difusos.

No entanto, essa relação é invariavelmente rompida cedo demais pelo ambiente, "o que acaba tendo como consequência a instauração de tendências na criança como o descontentamento, a avareza insaciável e o desejo de manter-se agarrado [...]" (Peixoto Junior, 2013, pp. 31-32). Sendo assim, o trauma gerado pela tomada de consciência dessa separação faz com que o sujeito desenvolva certos 
tipos de atitudes que, fundamentalmente, buscam o mesmo objetivo - a restauração da harmonia do amor primário. Peixoto Junior ressalta que é sobre a égide do amor primário que "[...] relações de objeto defeituosas, patológicas podem instaurar-se como reação a um trauma" (Peixoto Junior, 2013, p. 38) - correspondendo a esse trauma justamente a perturbação da harmonia do amor primário a partir do surgimento dos objetos. Balint (1959) destaca duas dessas relações, denominadas ocnofilia e filobatismo, cujas principais ideias serão abordadas a seguir.

\subsubsection{Ocnofilia}

Ao tratar os eventos surgidos da perturbação da harmonia da mistura do amor primário, Balint (1959) afirma que qualquer tentativa de utilizar uma abordagem em termos de experiências orais primitivas seria um fracasso. Por isso, sugere uma nova terminologia. $\mathrm{O}$ primeiro desses fenômenos que será abordado neste trabalho é a ocnofilia, derivada do verbo grego utilizado para significar "encolher", "hesitar", "agarrar", "empacar". O autor utiliza este termo para classificar o sujeito que se agarra, se apega ferrenhamente - a expressão inglesa mais apropriada seria clings to - ao objeto para evitar os terríveis e insuportáveis espaços vazios.

Embora Balint (1959) frequentemente afirme que não é possível determinar a cronologia do filobatismo e da ocnofilia, esta costuma ser classificada como uma posição mais primitiva do que aquela:

[...] a ocnofilia nos impressiona como a atitude mais espontânea, quase um reflexo, enquanto não se pode afirmar com certeza a que nível o filobatismo de fato pertence. Ademais, o aparecimento de tendências ocnofílicas em situações aparentemente puramente filobáticas sugere um tipo de tendência regressiva e, concomitantemente, uma natureza mais primitiva de parte da ocnofilia. (Balint, 1959, p.27)

Segundo o autor isto se provaria pelo fato de a atitude de largar necessariamente presumir que, anteriormente, algo tenha sido agarrado: "Um paralelo imediato é a forma com que a criança se agarra à mãe antes de deixá-la, de ir embora" (Balint, 1959, p.27).

Podemos perceber então que a ocnofilia envolve uma grande quantidade de ansiedade e medo que emergem da falta de confiança por parte do sujeito quanto 
à sua própria sobrevivência no caso da perda do objeto, já que não se atingiu um nível de maturidade tal que o "soltar" do objeto possa ser tolerado e encarado com naturalidade. Não há qualquer indício de que, uma vez largado, o objeto possa ser reencontrado, da mesma forma que um marinheiro jogado para fora de seu navio em uma tempestade não sabe se retornará ao barco. Este espaço vazio, livre de relações objetais, é vivido de forma ameaçadora e deve ser evitado a todo custo. Para isso, o ocnofílico prende-se a um objeto como um polvo - o contato táctil deve ser constante para certificar-se de que o objeto não se perca e, caso ocorra, possa encontrar um outro o mais rápido possível:

Primeiramente vamos olhar a ocnofilia onde alguma relação objetal é incondicional e o envolvimento de medo é óbvio. [...] [O agarrar] ocorre devido ao medo, vergonha ou pena em relação a um objeto. Obviamente deve haver um objeto disponível, caso contrário o indivíduo não poderá se agarrar. Consequentemente, o mundo ocnofílico consiste de objetos separados pelos terríveis espaços vazios. O ocnofílico vive de objeto em objeto, reduzindo sua jornada pelos espaços vazios o máximo possível. O medo é provocado por deixar os objetos, e aliviado por reencontrá-los. (Balint, 1959, p.32)

Balint (1959) identifica importantes semelhanças entre o tipo de relação objetal do ocnofílico e as características do amor primário - a demanda pelo objeto é absoluta, ele precisa estar lá caso surja alguma necessidade e, caso esta presença não se cumpra, será retaliado, tendo em vista que o autor considera a relação ocnofílica pré-depressiva, no sentido kleiniano (e, portanto, anterior ao concernimento, em termos winnicottianos). Para manter-se sempre relacionado, o indivíduo passa de objeto a objeto, já que o espaço vazio pode representar uma ameaça à sua constituição como sujeito, como um bêbado trôpego que se apoia em qualquer poste, mesa ou parede para não cair. O autor descreve então os ocnofílicos como "pessoas que podem sentir-se seguras apenas se estão em contato próximo com um objeto ou objetos, isto é, pessoas conhecidas, ideias e crenças. [...] Eles se sentem perdidos sem seus objetos, externos ou internos, então são capazes de criticá-los ou trocá-los somente com dificuldade e desconfiança" (Balint, 1959, p.39).

A tragédia ocnofílica é que o "apego" (clinging) está fadado ao fracasso. Além de o objeto alvo da relação ocnofílica nunca passar de um substituto, um representante da harmonia vivida anteriormente, ele é também dotado de vida própria, nem sempre apresentando-se disponível ao sujeito: 
Primeiramente, o objeto, ainda que sintonizado com o sujeito, tem sua própria vida, e ocasionalmente precisa seguir seu próprio caminho, o que consequentemente significa que há um constante perigo de o indivíduo ser largado pelo objeto, perigo que periodicamente torna-se um amargo fato. [...] Por fim, o verdadeiro objetivo nunca pode ser alcançado pelo apego. O real objetivo é ser segurado pelo objeto, e não agarrar-se desesperadamente a ele; este ser segurado deveria ocorrer sem a necessidade de expressar qualquer desejo por isso. É o mais precioso objetivo de cada um de nós que nosso ambiente satisfaça nossos desejos - especialmente nosso desejo de segurança - sem que nem ao menos precisemos pedi-lo. (Balint, 1959, p.34, grifo meu)

Segundo o autor, o ocnofílico tem consciência de que o objeto existe externamente, à parte de sua existência, "mas ele finge - em sua impotente onipotência - que eles nunca o deixarão se ele ligar-se inseparavelmente a eles" (Balint, 1959, p.79). Dessa forma a relação objetal estabelecida pelo ocnofílico adquire uma natureza peculiar devido à imprevisibilidade do objeto: “Objetos são meramente aceitos, mas não confiáveis; eles são necessitados, mas não se pode perder o controle sobre eles" (Balint, 1959, p.40). Isso decorre da falta de confiança que o indivíduo possui em relação ao objeto gerada por uma falha na adaptação do ambiente no contexto do amor primário. Como mencionado anteriormente no presente trabalho, Balint sugere em um texto anterior, dedicado à exposição do conceito de amor primário, que "esta relação íntima [o amor primário] é cortada pela nossa civilização de forma demasiadamente precoce. As consequências desse corte precoce são, entre outras, a conhecida tendência ao agarramento, o desgosto geral e a ganância insaciável de nossas crianças" (Balint, 1937, p.102, grifo meu). Dessa forma, é possível entender que uma separação precoce na relação mãe-bebê - ou seja, uma perturbação da mistura harmoniosa interpenetrante do amor primário em decorrência do surgimento de objetos - antes que o sujeito adquira uma consistência psíquica suficientemente confiante a ponto de poder aproveitar as expansões amistosas, flutuar nas substâncias sem precisar prender-se a nada, demanda uma regressão a um estado primitivo em que depende-se absolutamente do objeto.

\subsubsection{Filobatismo}


Além da ocnofilia, Balint sugere uma designação para um segundo tipo de relação objetal também decorrente do surgimento dos objetos na vida psíquica: o filobatismo. O termo tem suas origens nos acrobatas, artistas circenses representados desde a Grécia antiga, que impactam o público com a exibição de suas habilidades em situações de perigo - caminhar em cordas-bambas, montar um cavalo de pé sobre suas costas ou voar nos trapézios. De acordo com Balint (1959), quanto maior a distância entre o acrobata e o chão ou mais precário seu equipamento de segurança, mais arrebatadora é a sensação do público. Assim, Balint cria um amálgama entre a palavra "acrobata" (que, em grego, significa "aquele que anda nas pontas dos pés", está afastado da terra firme) e "filo", para denotar sua atração por este tipo de situação.

O filobatismo representa justamente o oposto da ocnofilia: o filobata não apenas deixa de buscar o objeto, este lhe é tão dispensável quanto perigoso. Enquanto o ocnofílico encontra segurança apenas no contato direto com os objetos, estes representam para o filobata um obstáculo a ser superado ou evitado. O filobata vive a partir das expansões amistosas, relacionando-se confortavelmente com os espaços vazios, ou seja, consegue vivenciar a harmonia com as substâncias do amor primário caso os objetos não o perturbem. Segundo Balint, em relação ao ocnofílico:

O mundo todo é diferente para o filobata. Desde que os elementos não sejam demasiadamente inclementes [...] o piloto está seguro no céu, o marinheiro no alto mar [...]. Perigo e medo são evocados apenas se um objeto parece precisar ser negociado; o piloto precisa decolar ou aterrissar, o marinheiro deve entrar ou sair do porto [...]. Podemos então dizer que o mundo filobático consiste de expansões amistosas povoadas mais ou menos densamente de objetos perigosos e imprevisíveis. O indivíduo vive nas expansões amistosas, cuidadosamente evitando perigosos contatos com objetos potencialmente perigosos. (Balint, 1959, p.34)

No entanto, o filobata aceita um grupo limitado de "objetos", que Balint (1959) chama de "equipamento" (equipment ou gear) - a vara do equilibrista, o trapézio do trapezista, o chicote do domador de leões, ou até mesmo o wingsuit de alguns paraquedistas modernos. Pode-se considerar perigoso denominar o equipamento do filobata de objeto, já que ele é frequentemente percebido pelo sujeito como uma extensão de sua própria habilidade - é algo que está sob o controle do filobata, digno de toda a sua confiança, conservando as características 
de um objeto interno: "Eles [os filobatas] parecem evitar objetos independentes, e podem de fato parecer estimar apenas aqueles objetos sobre os quais exercem completo e absoluto controle, os quais são realmente parte deles mesmos - o tipo de coisa que um atleta chamaria de seu equipamento" (Balint, 1959, p.40). O autor chama os objetos do equipamento filobático de objetos ocnofílicos, aos quais o filobata se agarra para reafirmar sua própria segurança a partir de um símbolo da segurança materna. Este cenário constituiria uma tendência regressiva a partir de uma atitude ocnofílica em uma situação filobática.

Balint oferece uma visão bastante interessante sobre a forma com que os objetos se apresentam ao filobata:

De alguma forma seus objetos são remanescentes dos personagens coadjuvantes dos contos de fadas, que podem ser tanto ajudantes ou associados do herói como seus adversários; e outra característica de tais personagens é que eles podem repentinamente mudar de uma classe para outra devido a eventos aparentemente pequenos. (Balint, 1959, p.35)

Tratar o filobata como um herói de contos de fada não foi uma fortuita escolha de palavras de Balint - segundo o autor, é assim que o filobata é percebido pela sociedade (ao contrário do ocnofílico, visto como um indivíduo covarde, dependente e ansioso). Segundo o autor, "a reação do filobata é o que geralmente se chama de heroica: voltar-se ao perigo iminente, virar-se a ele para encará-lo, manter-se distante dos objetos que oferecem falsa segurança, mantendo-se de pé por si só" (Balint, 1959, p.38). O ousado trapezista, que pula de um balanço para o outro no ar; o destemido equilibrista, que desafia a gravidade. Em uma visão mais contemporânea ele poderia ser retratado como o empreendedor, que aposta tudo o que tem para abrir um novo negócio ou pelo caso de Christopher McCandless, cuja biografia foi retratada no filme "Na Natureza Selvagem" (2007), de Sean Penn, em que o rapaz doa todas as suas economias e posses para a caridade para viver no Alaska em comunhão com a natureza, isolado de todos, sem nada de que não precisasse (apenas seu equipamento seria suficiente).

A rejeição aos objetos é intensamente percebida no caso do equilibrista. Não há muito que seja necessário, apenas suas sapatilhas e sua vara, para auxiliar seu equilíbrio. Objetos adicionais possuem conotação exibicionista: o monociclo ou os malabares, adereços à sua performance que cativam ainda mais seu público. 
Philippe Petit demonstra isso com muita clareza no documentário "O Equilibrista" (2008), mostrando como conseguiu, com a ajuda de alguns amigos, invadir o World Trade Center (que ainda estava em construção), puxar um cabo de aço entre as duas torres e atravessá-lo sem qualquer equipamento de segurança. A descrição de Petit sobre a experiência, sua visão concentrada no outro lado da linha, a forma com que se perdeu em tempo e espaço (sem perceber, Petit atravessou a linha entre as torres por oito vezes) é bastante consonante com a ideia de Balint sobre a experiência filobática. Petit entrou em confluência com o ambiente, flutuou nas expansões amistosas - que só seriam perturbadas por ruidosos objetos: a chegada da polícia.

Assim, é possível perceber que o filobata, ao contrário do ocnofílico, aceita a separação do objeto e contenta-se em observá-lo a certa distância com a certeza de que pode reecontrá-lo posteriormente caso deseje. $O$ autor afirma que “obviamente, elas [as atitudes filobáticas] podem desenvolver-se apenas após uma aceitação emocional do fato que sujeito e objeto possuem existências separadas, que ambos de fato continuam a existir mesmo quando não estão mais em contato próximo um com o outro [...]” (Balint, 1959, p.37). A tolerância do filobata a essa separação decorre da confiança no ambiente que proporcionou um desenvolvimento não traumático com ansiedade reduzida. Por outro lado, o ocnofílico experimenta uma intensa ansiedade sobre a separação, justamente pela instabilidade do ambiente que não o sustentou satisfatoriamente.

No entanto, é importante ressaltar que o filobata busca o mesmo que o ocnofílico, isto é, a segurança de outrora. A diferença está na atitude frente ao objeto: "Enquanto o ocnofílico vive a ilusão de que enquanto está em contato com um objeto seguro ele mesmo está seguro, a ilusão do filobata é de que, além de seu próprio equipamento, ele não precisa de nenhum objeto, certamente nenhum objeto em particular" (Balint, 1959, p.35, grifado no original). Assim, enquanto o ocnofílico busca a segurança na ferrenha e constante relação com seu objeto escolhido, o filobata a encontra na ligação com o mundo como um todo.

Percebemos então a corajosa tentativa de Balint em propor uma nova formulação teórica que permitisse um olhar diferente sobre as atitudes primitivas sem que se prenda a uma dinâmica de oralidade ou a termos emprestados da biologia. $\mathrm{O}$ autor afirma: 
Chegou o momento em que o pensamento analítico deve desfazer-se do hábito de descrever tudo que é primitivo como 'oral', caso contrário, nossa teoria ficará reduzida ao absurdo. [...] Por mais de trinta anos eu venho criticando o hábito de descrever as várias formas de relações objetais exclusivamente em termos emprestados da biologia, isto é, o estudo dos instintos. [...] Embora úteis até certo ponto, esses termos são restritivos e neutralizadores. (Balint, 1959, p.137)

Foi com o intuito de romper com essa tradição organicista que Balint cunhou os termos "ocnofilia" e "filobatismo", que descrevem os tipos de atitudes primitivas direcionadas ao mundo. Balint resume tal cenário da seguinte forma:

Começando com o mundo pré-anaclítico da mistura harmoniosa, em que ainda não existem objetos, minhas ideias tentam descrever de certa forma as consequências da emergência dos objetos. Algumas pessoas reagem a essa descoberta desenvolvendo catexias objetais exageradas, faculdades eficientes para preservar seus objetos importantes e para agarrar-se a eles, enquanto deixa de desenvolver seu ego independente; estes são os ocnofílicos. Outros [os filobatas] reagem à mesma descoberta desenvolvendo catexias egóicas exageradas que levam a uma preocupação indevida com suas funções egóicas, as habilidades pessoais, e a negligenciar o desenvolvimento de relações objetais apropriadas, íntimas e duradouras. (Balint, 1959, p.136)

Trata-se, então, principalmente, da diferença na forma com que o sujeito direciona sua catexia primária - posteriormente, Balint (1969) afirmaria que a catexia primária do ocnofílico adere aos objetos emergentes, que adquirem a natureza de um porto seguro em um mar tortuoso; enquanto os espaços entre os objetos, as expansões livres de objetos, assumem-se como alvo da catexia primária do filobata, como um esquiador que busca os espaços abertos desviando-se das pedras e árvores: “[...] aparentemente, ele [o ocnofílico] escolhe superinvestir suas relações objetais. $\mathrm{O}$ outro tipo, o filobata, superinveste suas próprias funções egóicas e desenvolve habilidades dessa forma, a fim de manter-se sozinho com muito pouca, ou até nenhuma, ajuda de seus objetos" (Balint, 1969, p.68, grifado no original).

Outra importante distinção entre os mundos ocnofílico e filobático diz respeito ao sentido que os governa. Enquanto o tato predomina na atitude ocnofílica, através do contato constante com o objeto, o filobata é guiado pela visão, o que fica bastante claro através do discurso do equilibrista Philippe Petit, mencionado anteriormente. Contudo, ainda que trilhem caminhos diferentes, tanto o ocnofílico quanto o filobata adotam tendências regressivas que buscam a segurança perdida com a emergência dos objetos e, indissociavelmente, do mundo externo. 
Finalmente, é importante destacar que esses dois tipos descritos por Balint constituem casos extremos, uma opção adotada pelo autor não para descrever indivíduos filobatas ou ocnofílicos, mas atitudes filobáticas e ocnofílicas que se apresentam no mesmo sujeito com graduações que podem pender para um lado ou para o outro: "De fato, esses casos extremos são raramente encontrados na realidade; o que frequentemente nos confronta são variadas misturas das duas relações objetais descritas; onde uma atitude pode ser usada para reprimir ou até supercompensar a outra em várias combinações nas variadas camadas da mente" (Balint, 1959, p.32). Da mesma forma que o pescador de Dorival Caymmi tem dois amores - um bem na terra, um bem no mar - o indivíduo se vale tanto da solidez encontrada no superinvestimento dos objetos quanto da segurança proporcionada pelas expansões amistosas. Trata-se, portanto, de uma concepção teórica sobre processos primitivos derivados do trauma, desenvolvida em uma dimensão relacional de imensa riqueza para a prática clínica, em especial na compreensão e manejo de dinâmicas regressivas na situação analítica. Todavia, antes que seja possível melhor abordar tais questões clínicas, devemos tratar de mais um fundamental conceito balintiano que está intimamente relacionado a toda a questão da clínica do trauma de Balint: a Falha Básica.

\subsubsection{A falha básica e as três áreas da mente}

A nova tópica proposta por Balint (1969) se divide entre as três áreas da mente: a área da criação, a área da falha básica e a área edipiana. A última remete à área do conflito edipiano, aquela sobre a qual temos mais informações, devido principalmente a dois motivos: (1) a semelhança entre o tipo de relação estabelecida entre o sujeito e seus objetos e a forma com que os adultos se relacionam; (2) a linguagem adulta é bastante adequada para descrever e abordar os fenômenos da área edípica. Nesta área, o tipo de relação já é triangular, estabelecida entre um sujeito e dois objetos, e a força dinâmica que lhe é característica se origina de um conflito. Assim, já existe certa maturidade subjetiva que permite uma organização mais complexa, de forma que a linguagem empregada pelo sujeito se encontra mais próxima de um fenômeno compartilhado com o mundo adulto. Segundo o autor 
(1969), os pacientes cuja falha remeta a esta área são aqueles aos quais a técnica clássica se propunha a tratar, a partir principalmente do uso das interpretações.

Já a área da criação, a mais primitiva dentre as três, é descrita por Balint através da ausência de qualquer objeto externo - existem apenas pré-objetos que não podem ser considerados nem íntegros nem organizados: "O sujeito está sozinho e sua principal preocupação é produzir algo a partir de si mesmo; este algo a ser produzido pode ser um objeto, mas não necessariamente o é” (Balint, 1969, p. 24). Como fenômenos pertencentes à área da criação Balint enumera não apenas o processo artístico, o mais óbvio entre eles, mas também "matemática e filosofia, alcançar um insight, entender algo ou alguém; e por fim, mas não menos importante, dois fenômenos extremamente importantes: as fases iniciais de 'adoecer' fisicamente ou mentalmente - e espontaneamente recuperar-se dessa 'doença", (Balint, 1969, p. 24).

De acordo com o autor, a área da criação é pouco acessível a nós e, portanto, a mais desconhecida entre as três áreas da mente. Devido à ausência de objetos na área da criação, ela se torna inacessível através da transferência, tornando sua observação mais difícil - nos resta apenas inferir a partir do que notamos quando o indivíduo deixa a área após um processo criativo. Apenas quando um objeto é gerado por esse processo (uma tese, uma reflexão ou mesmo uma reclamação sobre a doença) temos algum material com que trabalhar.

Existe ainda mais um problema que dificulta a exploração e a própria descrição da área da criação, o uso de nossa linguagem adulta:

Nós sabemos que não há 'objetos' na área da criação, mas também sabemos que durante a maior - ou alguma - parte do tempo o sujeito não está completamente sozinho ali. O problema é que nossa linguagem não possui palavras para descrever, ou mesmo indicar, os 'algos' que estão ali quando o sujeito não está completamente sozinho, de forma que possamos falar sobre eles, proponho o uso do termo 'pré-objeto' [...]. (Balint, 1969, p. 25)

Segundo Balint, Bion teria passado pelo mesmo problema quanto à nomenclatura, chamando os pré-objetos de elementos $\beta$, os objetos já organizados de elementos $\alpha$ e, por fim, o processo de criação como explorado por Balint de função $\alpha$. Assim, o processo de criação, segundo Balint (1969), representa justamente a transformação de um pré-objeto em um objeto definido e organizado. 
Embora se trate de um fenômeno da área da criação, na qual os objetos estão ausentes, este processo pode também ocorrer de forma regressiva em uma situação do nível edipiano ou da falha básica, como através do próprio silêncio do paciente na situação analítica, mesmo em uma relação bipessoal. Essa ideia será retomada no capítulo seguinte do nosso trabalho.

Por ora resta mencionar a área da falha básica, aquela à qual Balint dedicou maior parte de sua obra, tendo em vista a riqueza de seu material no campo clínico, justamente por envolver uma relação bipessoal (mais simples do que a relação triangular edipiana). A ocnofilia e o filobatismo, discutidos anteriormente neste capítulo, representam duas de várias instâncias da falha básica, derivadas de uma descoberta traumática do valor ilusório da relação dual primitiva mãe-bebê.

Embora seja certamente mais simples e primitiva do que a área do complexo de Édipo, a área da falha básica não deve ser chamada de pré-edipiana o mais adequado seria dizer que se trata de fenômenos não edipianos, já que, além da possibilidade de coexistência de eventos de ambas as áreas, a falha básica não representa uma fase ou estágio, mas justamente uma falha que é sentida como tal pelo indivíduo. Sobre a escolha do termo "falha básica", Balint explica:

Todos esses eventos pertencem essencialmente ao campo da psicologia bipessoal e são mais elementares do que aqueles pertencentes ao nível edipiano tripessoal. Ademais, eles não possuem a estrutura de um conflito. Essa foi uma das principais razões de por que propus chama-la 'básica'. Mas por que falha? Primeiramente, porque esta é exatamente a palavra utilizada por muitos pacientes ao descrevê-la. O paciente diz sentir que há uma falha dentro dele, uma falha que deve ser corrigida. E é sentida como uma falha, não um complexo, não um conflito, não uma situação. Segundo, há um sentimento de que a causa desta falha é que alguém falhou com o paciente ou o negligenciou; e terceiro, uma grande ansiedade invariavelmente envolve esta área, normalmente expressada como uma demanda desesperada de que desta vez o analista não deve - e, de fato, não pode - falhar com ele. (Balint, 1969, p. 21)

Assim, percebemos que a falha básica possui a característica de uma deficiência, de algo que está errado. É importante destacar que a força dinâmica operante nesse contexto não é a de conflito, mas exatamente de falha: "Essa palavra [falha] é usada em seu sentido geológico, e não moral, e descreve uma súbita irregularidade na estrutura geral que, sob estresse, pode levar a uma ruptura, o que perturba profundamente essa estrutura geral. Na mente, a forma da falha é de uma experiência de algo distorcido ou deficiente na mente, o que produz um defeito que 
deve ser corrigido" (Stewart, 1996, p. 61). Embora essa falha possa ser resolvida até certo ponto, ela nunca desaparece por completo, uma marca estará sempre presente: "Uma demanda instintual pode ser satisfeita, um conflito pode ser resolvido, uma falha básica pode talvez ser meramente curada dado que os ingredientes deficientes possam ser encontrados; e até assim pode-se atingir apenas uma cura defeituosa, como uma simples e indolor cicatriz" (Balint, 1969, p. 22). Assim, as consequências da falha básica são apenas parcialmente reversíveis, segundo a ótica do autor.

A falha básica surge de uma espécie de desajuste entre sujeito e ambiente em um momento precoce. Nesta situação, existe uma discrepância entre as necessidades físicas e psicológicas da criança e os cuidados que o ambiente the proporciona. A causa deste abismo, segundo Balint (1969), pode ser congênita, havendo uma exigência demasiadamente elevada de parte das necessidades da criança, ou ambiental, quando o cuidado é simplesmente insuficiente ou exagerado - isto é, inadequado. Peixoto Junior sugere que a hipótese de Balint "[...] é a de que a origem dessa deficiência fundamental possa estar em uma discrepância considerável entre as necessidades do indivíduo durante os seus primeiros anos (ou possivelmente meses) de formação e os cuidados e a atenção disponíveis em momentos importantes" (Peixoto Junior, 2013, pp. 50-51). Podemos perceber, dessa forma, muitas similaridades entre as noções de trauma desenvolvidas por Balint e Winnicott, especialmente no que concerne ao papel desempenhado pelos cuidados e as falhas do ambiente na ocasião do desenvolvimento primitivo e suas implicações na traumatogênese.

De forma geral, a questão-chave relativa à falha básica é determinada por Balint como esta falta de ajustamento, de adequação entre a criança e o ambiente. Segundo Peixoto Junior, "a passagem traumática da situação originária de harmonia para a constituição mais definitiva dos objetos funda o que a teoria balintiana chamou de falha básica" (Peixoto Junior, 2013, p. 50) - ou seja, o trauma derivado de uma perda da sintonia existente no amor primário. Semelhante desajuste pode ser observado na clínica, entre a técnica do analista e as necessidades do paciente o que representa justamente o fracasso que Balint pretendia evitar ao discorrer sobre a falha básica na configuração analítica. Ademais, o tipo de relação estabelecida na 
área da falha básica adquire grande importância no setting, uma vez que Balint considera que ambas as situações são definidas como relações bipessoais.

Existe, assim, uma grande diferença entre o paciente do nível da falha básica e o do nível edipiano. Este último faz uso da linguagem em uma dimensão compartilhada - as palavras conservam, para ele, o mesmo valor atribuído pelas demais pessoas - elaborando verbalmente o material discursivo trazido para a análise, o que somente pode ocorrer quando tanto paciente quanto analista são capazes de fazer um uso semelhante da função das palavras. No entanto, sendo o nível da falha básica mais simples, mais primitivo do que o nível edípico, é utilizada uma linguagem diferente daquela do mundo adulto. Pelo contrário, a linguagem adulta pode ser enganosa ou mesmo inútil, a interpretação (verbal) pode não ser clara para o paciente ou nem mesmo experienciada como tal - o que é mais marcante para o paciente é o afeto carregado naquela interpretação, que é sentido como um ataque, uma invasão, uma demanda ou mesmo uma tentativa de sedução. A questão para o paciente regredido ao nível da falha básica, portanto, transcende a linguagem, as palavras, o valor elaborativo da interpretação, baseando-se principalmente na qualidade da relação estabelecida entre ele e o analista.

Embora tanto o nível da falha básica como o nível edipiano constituam no ambiente clínico tendências regressivas, podemos perceber o quão diferente é o seu manejo. Uma atitude adequada à demanda regressiva do paciente é determinante para o sucesso ou o fracasso da análise, como veremos no terceiro capítulo desta tese.

\subsection{Winnicott - o funcionamento psíquico primitivo e a ruptura da continuidade de ser}

Em um artigo de 1967, apresentado em um simpósio nos Estados Unidos, Winnicott declarou o seguinte: "Pode ser que, enquanto pratico minhas escalas e arpejos, eu possa oferecer matéria para discussão. Não estou preocupado nem em ser original nem em citar outros autores pensadores (nem mesmo Freud)" (Winnicott, 1967a, p. 193). De fato, é bastante incomum encontrarmos referências diretas de parte de Winnicott a outros autores - segundo Rodman (1972/1995) ele 
aceitaria as reprimendas que recebeu de parte de Ernest Jones e James Strachey, em correspondências com ambos, pela sua falta de dedicação na leitura das obras de Freud. Por outro lado, é possível acreditar que essa liberdade permitiu que Winnicott desenvolvesse uma linha de pensamento de irrefutável singularidade dentro da teoria psicanalítica - ainda que tal originalidade só pudesse se basear na tradição, como assumiria em outro trabalho do mesmo ano (1967b/1975).

Ainda assim, é possível identificar muitas influências, ainda que indiretas, ao longo do trabalho de Winnicott. Embora tenha se apropriado, absorvido e diluído essas ideias em sua própria mistura, sua obra é permeada por conceitos e construções de muitos psicanalistas, como Freud, Klein, Fairbairn e Rank. No entanto, podemos perceber ainda a influência de Ferenczi, tanto em sua teoria quanto em sua prática clínica, ainda que ele dificilmente fizesse qualquer referência ao autor húngaro. Devemos ter em mente que uma das supervisoras de Winnicott foi Melanie Klein (de imensa importância para a formação do autor inglês), outrora paciente de Sándor Ferenczi enquanto residiu em Budapeste. Ademais, diversos autores - como Figueiredo (2002), Moreno \& Coelho Junior (2012), Lejarraga (2008) e Kupermann (2008) - identificam muitas similaridades entre as ideias dos dois autores, algo que será pontuado ao longo desta tese.

Uma das inspirações que Winnicott parece ter encontrado em Ferenczi recai sobre seus interesses no campo da psicanálise. Assim como Ferenczi, Winnicott dedicou-se intensamente ao estudo tanto da patogênese quanto do tratamento daquilo que o húngaro chamava de "casos difíceis" - na ótica de Winnicott, os casos limítrofes ou borderline e as patologias psicóticas -, assim como aos fenômenos que ocorriam nos estágios iniciais da infância (campo explorado pelo autor com grande riqueza, considerando sua imensa experiência como pediatra de Paddington Green). De acordo com o relato do autor (1945/2000), tal interesse surgiu da demanda encontrada em sua prática clínica - seus pacientes apresentavam déficits psíquicos muito primitivos, obtendo resultados bastante insatisfatórios a partir da técnica clássica, o que pode ser visto através do caso Margaret Little, cujo manejo será discutido no próximo capítulo.

Ao longo dos anos, Winnicott foi dirigindo crescente atenção à questão do trauma, em especial aquele de sentido mais primitivo. No entanto, ele pode ser 
considerado um autor, de certa forma, otimista. Sua teoria ocupa-se primeiramente da perspectiva da saúde, isto é, do que ocorre quando tudo vai bem. Dessa forma, para melhor compreendermos a visão de Winnicott acerca do trauma, devemos antes esclarecer melhor como o autor entende os momentos iniciais da vida psíquica, bem como os personagens, acontecimentos e processos atrelados a este momento.

\subsubsection{O funcionamento psíquico precoce e o ambiente suficientemente bom}

De acordo com uma nota de rodapé incluída em Teoria do relacionamento paterno-infantil (1960a/1983), uma das mais célebres (e controversas) ideias de Winnicott, segundo o qual não existiria essa coisa chamada bebê, teria sido mencionada por ele pela primeira vez em uma discussão na reunião científica da Sociedade Britânica de Psicanálise por volta de 1940. A essência deste argumento reside na ideia de que é impossível conceber o bebê de forma isolada de seu entorno, ou seja, do ambiente que o sustenta. Alguns anos mais tarde, o autor complementaria: "Uma vez, arrisquei a observação, 'Não existe coisa tal como um bebê' - significando que se você tentar descrever um bebê, perceberá que está descrevendo um bebê e mais alguém. Um bebê não pode existir sozinho, ele é essencialmente parte de uma relação" (Winnicott, 1964, p. 88, grifado no original).

Assim, o bebê descrito por Winnicott é algo mais do que um elemento que não pode ser dissociado do ambiente - ele não é um elemento em si, mas algo que se encontra em estado de fusão com a mãe. Esse tipo específico de relação - uma unidade dual - poderia ser encarado como um prolongamento da vida pré-natal, em que não havia diferenciação entre mãe e bebê, sem um ponto em particular que definisse onde um terminava e outro começava. De acordo com o autor (1949/2000), se trata de uma espécie peculiar de relacionamento, que tem início na gestação e pode perdurar até mesmo após o nascimento. Ao descrever a situação que se desenrola antes que seja possível ao bebê obter o status de unidade, Winnicott sugere:

Gostaria apenas de deixar aqui a observação de que quanto mais recuarmos na história individual, mais verdadeira torna-se a proposição segundo a qual não há 
sentido em falarmos sobre o indivíduo sem considerarmos um ambiente suficientemente bom que se adapta às suas necessidades. Nos estágios iniciais chegamos inclusive a uma situação em que somente o observador poderá distinguir entre o indivíduo e o ambiente (narcisismo primário). $O$ indivíduo não o poderá fazer, e neste caso será mais adequado falar de um conjunto ambienteindivíduo, em vez de nos referirmos a um indivíduo. (1955a/2000, p. 360)

Percebemos, dessa forma, uma importante diferença entre Winnicott e Balint. Ao contrário deste, Winnicott não rejeita a noção de narcisismo primário, recorrendo ao que Freud escrevera em Inibição, sintoma e angústia, de 1926 - isto é, o retrato do feto (e, consequentemente, da criança imediatamente após o nascimento) como uma criatura completamente narcisista para quem a mãe como objeto é totalmente desconhecida, uma vez que ambos fazem parte dessa unidade. É importante destacar, no entanto que a noção winnicottiana de unidade dual não é idêntica àquilo que Freud chamava de narcisismo primário, já que, como percebemos no termo empregado por Winnicott, a unidade é formada pelo encontro entre duas partes, o bebê e a mãe. Ainda assim, enquanto Balint acreditava que o bebê se relacionava com o ambiente - este, pré-objetal, na forma das substâncias , é difícil dizer que Winnicott considera que exista algum tipo de relação objetal, uma vez que o indivíduo e o ambiente encontram-se em uma fusão, indiferenciados. Não há ainda um sujeito que possa relacionar-se com o ambiente:

Pode ser dito que o self da criança, nesse primeiro estágio, é somente potencial. $\mathrm{Na}$ regressão a esse estado, o indivíduo torna-se imerso no self da mãe. O self da criança ainda não está formado e, portanto, não podemos dizer que está imerso, mas recordações e expectativas podem agora começar a acumular-se e a estruturar-se. (Winnicott, 1965/1980, p. 29)

Devemos considerar, portanto, que o princípio da vida psíquica é configurado por um encontro entre bebê e mãe (o que difere do conceito freudiano do narcisismo primário) em que esta corresponde ativamente às necessidades do primeiro. O ambiente que desempenha bem essa função é chamado por Winnicott não de ideal, mas de suficientemente bom - uma terminologia escolhida pelo autor com grande precisão, como veremos adiante - capaz de proporcionar ao bebê uma ilusão de onipotência que constituirá a base para o viver criativo:

Ele [Winnicott] propõe que o desenvolvimento emocional primitivo bem sucedido depende da negociação da sobreposição de duas experiências de estar vivo, a da mãe e a do bebê. Para o bebê, esses dois mundos são inicialmente um, e o papel da mãe a princípio permite uma ilusão, e então lida com o inevitável processo de desilusão no curso de sua provisão de cuidado comum. (Joyce \& Caldwell, 2011, p. 55) 
Mas a que corresponde tal ilusão? Winnicott considera um momento bastante primitivo durante o qual ocorre aquilo que chama de primeira mamada teórica. Tal situação é descrita pelo autor da seguinte maneira:

Em algum ponto teórico no início do desenvolvimento de cada indivíduo humano, este é capaz, dentro de um contexto fornecido pela mãe, de conceber a ideia de algo que irá satisfazer a necessidade que surge a partir da tensão instintiva. Não se pode dizer que o bebê saiba desde o início o que será criado. Neste momento a mãe se faz presente. Da maneira usual, ela dá ao bebê o seu seio e o seu anseio potencial por alimentar. A adaptação da mãe à necessidade do bebê, quando suficientemente boa, dá a este a ilusão de que existe uma realidade externa que corresponde à sua capacidade de criar. Dito de outro modo, há uma superposição entre o que a mãe fornece e o que o bebê é capaz de conceber. Para o observador, a criança percebe o que a mãe apresenta, mas esta não é toda a verdade. O bebê concebe o seio somente na medida em que um seio poderia ser criado ali e então. Não há intercâmbio entre a mãe e o bebê. Psicologicamente, o bebê mama num seio que é parte dele mesmo, e a mãe dá leite a um bebê que é parte dela mesma. Em psicologia, a ideia do intercâmbio baseia-se numa ilusão. (Winnicott, $1951 / 2000$, p. 328, grifos meus)

Percebemos, pelo fragmento acima, como se desenvolve essa sobreposição

entre o que o bebê necessita e espera e o que a mãe oferece, quando ambos encontram-se em um contexto suficientemente bom. A correspondência da parte da mãe ao potencial criativo do bebê permite a este usar a ilusão, o que fundamentará sua capacidade de relação com o ambiente, como nos ressalta Winnicott (1952/2000). Ademais, é essa maternagem suficientemente boa o que proporcionará o estabelecimento de um padrão pessoal próprio e um desenvolvimento emocional real:

Somente se há uma mãe suficientemente boa é que a criança inicia um processo de desenvolvimento que seja pessoal e real. Se a maternagem não é suficientemente boa, então a criança torna-se uma coleção de reações à imposição, e a verdadeira identidade da criança falha em se formar ou se torna escondida atrás de uma falsa identidade a que se submete e geralmente evita as solicitações do mundo. (Winnicott, 1965/1980, p. 29)

É importante destacar que a primeira mamada teórica descrita por Winnicott se desenrola em um contexto de dependência absoluta, a primeira das três categorias de dependência descritas por Winnicott - as outras duas são a dependência relativa e o que o autor (1963a/1983) nomeia "rumo à independência", uma vez que considera difícil pensar em uma independência total como algo além de um vislumbre, uma possibilidade teórica. 
A dependência absoluta corresponde à condição mais inicial em que o indivíduo se encontra em relação ao ambiente. Nesse momento, o bebê é tanto física quanto psicologicamente dependente de seu ambiente, ainda que não se dê conta disso - como não há consciência de algo que lhe seja alheio, o bebê é incapaz de perceber até mesmo o cuidado ambiental que lhe é provido. Winnicott ilustra essa afirmação ao sugerir uma referência à mãe enquanto banha seu bebê: "Eu lhes lembraria a temperatura da água do banho, testada pelo cotovelo da mãe; a criança não sabe que a água podia estar ou muito quente ou muito fria, mas vê de modo natural a temperatura corporal" (Winnicott, 1963a/1983, p. 82). Assim, quando tudo corre bem, o ambiente não é nem mesmo percebido - o que ocorre apenas em uma situação de falha, de ruído na relação. Não à toa, é possível identificar com bastante clareza uma relação muito próxima entre essa ideia e a forma com que Balint trata as substâncias pré-objetais (como discutido anteriormente neste capítulo). Ao oferecer esse exemplo, Winnicott recorda a sugestão de Balint (1969) sobre a relação com a substância ar - só nos damos conta de sua existência quando ele falta em nossos pulmões.

Tendo esclarecido a forma com que Winnicott percebe os mais iniciais momentos da vida emocional e o funcionamento da dinâmica entre o ambiente o bebê, devemos agora explorar um processo de grande relevância para compreendermos o conceito winnicottiano de trauma: o desenvolvimento emocional primitivo.

\subsubsection{Desenvolvimento emocional primitivo}

Ao longo de seu trabalho Desenvolvimento emocional primitivo, publicado em 1945, Winnicott descreve sua teoria a respeito de um processo que ocorre em um momento bastante inicial da vida psíquica. $\mathrm{O}$ autor declara que, embora muitos grupos psicanalíticos não considerem que ocorram experiências significativas até os seis meses de idade, esse momento consiste em uma etapa fundamental para a compreensão da patogênese dos fenômenos psicóticos que tanto observou em sua prática clínica - em especial durante a Segunda Guerra Mundial, quando a intensidade dos atendimentos a esses pacientes o deixava até mesmo desatento às bombas alemãs que explodiam em Londres. 
Segundo Winnicott (1945/2000), um certo processo de organização e maturação psíquica tem início por volta do momento do nascimento e perdura até cerca de cinco ou seis meses, sem que se deva considerar necessariamente prejudicial que se atinja um determinado patamar antes disso. O norte ao qual o desenvolvimento emocional primitivo se dirige é retratado por Winnicott da seguinte forma: "Estou descrevendo agora o estágio de desenvolvimento em que o bebê se torna uma unidade, passando a ser capaz de sentir o self (e portanto os outros) como um inteiro, uma coisa com membrana limitadora, e dotado de um interior e um exterior. Isto [...] responde pela totalidade do desenvolvimento que conduz até este sentimento de ser um" (Winnicott, 1988/1990, p. 87). Percebemos, portanto, que Winnicott sugere que o desenvolvimento emocional primitivo constitui a formação do psiquismo em uma pessoa íntegra, total e delimitada, capaz de reconhecer o mundo externo e os demais indivíduos igualmente como pessoas totais. $\mathrm{O}$ autor descreve de forma sucinta e precisa o bebê que conquista esse nível: "Pode-se dizer que nesse estágio o bebê já é capaz de mostrar, através de seu brincar, que ele compreende que tem um interior, e que as coisas vêm do exterior" (Winnicott, 1945/2000, p. 221).

Essa conquista é alcançada ao longo de três processos - integração, personalização e realização -, precedidos por um estado primário de não integração, "[...] uma ausência de globalidade tanto no espaço quanto no tempo" (Winnicott, 1988/1990, p. 136). Ainda não se pode falar em um ego definido (afinal, não há bebê), o que existe é uma "porção de pedacinhos" relativos aos impulsos e às experiências sensoriais vividas até então. Nem mesmo a mãe é reconhecida ainda como tal: "Quanto ao ambiente, pedaços da técnica do cuidar, de rostos vistos e sons ouvidos e cheiros cheirados são apenas gradualmente reunidos e transformados num único ser, que será chamado mãe" (Winnicott, 1945/2000, p. 224).

A integração, o primeiro desses três processos, corresponde à união desses pedaços, primeiramente em curtos momentos ou períodos, gradualmente tornandose um fato. Embora Winnicott privilegie o papel do ambiente no sucesso da integração, é importante destacar que esse processo é facilitado por dois lados, como nos recordam Joyce \& Caldwell: "Winnicott propõe que a personalidade é 
reunida internamente (integração) a partir da interação de duas arenas diferentes: pelo cuidado infantil comum (externamente), e pelas experiências instintivas (internamente)" (Joyce \& Caldwell, 2011, pp. 55-56). Winnicott (1988/1990) destaca o papel da exigência instintiva e da expressão agressiva na aglutinação do self, o que torna possível a consciência.

No que tange à função exercida pelo ambiente nesse momento, Winnicott sugere o holding, a técnica segundo a qual a mãe segura e dá suporte ao seu bebê, como um apoio fundamental à criança, já que esta se desmancharia em pedaços caso não houvesse alguém que a mantivesse inteira. $\mathrm{O}$ autor descreve o processo de integração a partir do cuidado provido pelo ambiente da seguinte forma:

A mãe sabe por empatia que quando se pega um bebê é preciso levar um certo tempo nesse processo. $\mathrm{O}$ bebê deve receber um aviso, as várias partes do corpo devem ser seguradas em conjunto; finalmente, no momento certo, a criança é levantada; além disso, o gesto da mãe começa, continua e termina, pois o bebê está sendo levantado de um lugar para outro, talvez do berço para o ombro da mãe. À medida que o self se constrói e o indivíduo se torna capaz de incorporar e reter lembranças do cuidado ambiental, e portanto de cuidar de si mesmo, a integração se transforma num estado cada vez mais confiável. Desta forma, a dependência diminui gradualmente. (Winnicott, 1988/1990, p. 137)

Percebemos, a partir do fragmento acima, que o holding corresponde a uma atitude muito mais complexa do que o colo em si. Trata-se de um suporte físico e psíquico (devemos recordar que Winnicott afirma diversas vezes ao longo de sua obra que, com a criança pequena, todo cuidado físico é também um cuidado psíquico) que ocorre tanto na dimensão espacial quanto temporal. O próprio autor define que "a integração significa responsabilidade, ao mesmo tempo que consciência, um conjunto de memórias, e a junção de passado, presente e futuro dentro de um relacionamento. Assim, ela praticamente significa o começo de uma psicologia humana" (Winnicott, 1988/1990, p. 140). O resultado desse suporte suficientemente bom é uma sensação de unidade e sanidade - o que ocorre de maneira análoga, posteriormente, em estados regredidos na análise a partir da fundamentação do setting, como aprofundaremos no próximo capítulo. É importante destacar, entretanto, que o processo de integração ocorre na esfera da dependência absoluta, como nos recorda Winnicott: "Todas as partículas e fragmentos de atividade e sensação que vão constituir aquilo que passamos a conhecer como este bebê específico começam a congregar-se em determinados 
períodos, de tal forma que há momentos de integração em que o bebê é uma unidade, embora, naturalmente, uma unidade muitíssimo dependente" (Winnicott, 1966/2013, pp. 8-9).

A integração, contudo, deve ser assumida como um estado precário, que coexiste com a ameaça de desintegração, a perda do desenvolvimento conquistado nesse sentido, o que motiva uma sensação de enlouquecimento. Decerto, uma maternagem suficientemente boa favorece o enfraquecimento dessa ameaça. No entanto, a falha ambiental (nesse contexto, o fracasso em carregar o bebê com segurança de forma além do tolerável para este) pode ocasionar exageros no cuidado consigo mesmo como uma defesa organizada contra a ameaça de desintegração que surgiu.

Existe, por outro lado, uma alternativa à desintegração. Winnicott sugere um retorno saudável a estados não integrados, precursores da capacidade adulta de relaxar - base daquilo que Winnicott (1958/1983) chama de "capacidade para estar só”. Todavia, a não integração poderia ser excedida, tornando-se ameaçadora e até mesmo perdida com o desenvolvimento em direção à independência:

$\mathrm{Na}$ vida da criança normal, o descanso deve poder incluir o relaxamento e a regressão para a não-integração. Gradualmente, à medida que o self se desenvolve em força e complexidade, essa regressão à não-integração aproxima-se mais e mais do doloroso estado de desintegração "enlouquecedora". Existe portanto um estado intermediário, no qual um bebê bem cuidado e em pleno desenvolvimento pode relaxar e não-integrar-se, e tolerar (mas apenas tolerar) sentir-se "louco" no estado não-integrado. Em seguida é dado um passo adiante, um passo em direção à independência, e à perda para sempre da capacidade de não-integração, exceto na loucura ou nas condições especializadas fornecidas pela psicoterapia. Deste momento em diante, o termo não é mais não-integração, e sim desintegração. (Winnicott, 1988/1990, pp. 138-139)

O segundo processo descrito por Winnicott é o da personalização, através do qual o bebê adquire a localização da psique dentro de seu corpo, ou seja, o estabelecimento da trama psicossomática. $\mathrm{O}$ autor ressalta que essa condição não é inerente a todos, pelo contrário, é algo que deve ser conquistado pelo bebê e facilitado pelo ambiente. Segundo ele:

Do ponto de vista do indivíduo em desenvolvimento [...] o self e o corpo não são inerentemente superpostos, embora para haver saúde seja necessário que esta superposição se torne um fato, para que o indivíduo venha a poder identificar-se com aquilo que, estritamente falando, não é o self. Gradualmente, a psique chega a um acordo com o corpo, de tal modo que na saúde existe eventualmente um 
estado no qual as fronteiras do corpo são também as fronteiras da psique. (Winnicott, 1988/1990, p. 144)

Da mesma maneira que no caso da integração, a personalização é produzida a partir da direção pessoal (experiência pessoal de impulsos, sensações da pele, erotismo muscular) e da ambiental (os cuidados com o corpo do bebê e a satisfação de suas exigências instintivas). Esse tipo de relação favorece o surgimento de uma membrana limitadora que, tal qual a pele, separa os conteúdos que foram agrupados a partir da integração daquilo que percebemos, em nossa qualidade de observadores, como o ambiente. Trata-se, portanto, da membrana que distingue tudo que é interno do mundo externo.

Novamente, assim como a integração, a conquista da personalização acompanha a possibilidade da perda do vínculo entre a psique e o soma, denominada despersonalização. Quando o cuidado ambiental não é suficientemente bom - seja pela sua ausência ou pelo seu excesso - essa ameaça se intensifica. Winnicott (1988/1990) ressalta, por exemplo, os prejuízos para o desenvolvimento da personalidade gerados pelo enfaixamento da criança ao espernear.

Embora o autor não estabeleça uma sequência necessária entre os processos do desenvolvimento emocional primitivo - pelo contrário, eles se sobrepõem - existe uma complexidade maior no terceiro deles, a realização. Havendo alguma aglutinação das experiências primitivas que constituíam o protótipo do bebê, bem como a delimitação do espaço que o próprio ocupa, começa então seu tortuoso trabalho de adaptação à realidade e relação com o mundo exterior.

Nesse contexto, a dependência absoluta está gradativamente se transformando em uma dependência relativa, ou seja, o bebê está tomando ciência do cuidado do ambiente porque está, aos poucos, tornando-se capaz de perceber o ambiente como tal e não como parte de si. Essa aquisição ocorre primeiramente a partir da experiência de ilusão, na qual a mãe proporciona ao bebê justamente aquilo que ele está esperando encontrar, como discutido anteriormente. Winnicott descreve essa situação da seguinte maneira:

No contexto do relacionamento do bebê com o seio materno (e não estou declarando que o seio é essencial como veículo do amor da mãe), o bebê tem 
impulsos instintivos e ideias predatórias. A mãe tem o seio e o poder de produzir leite, e a ideia de que ela gostaria de ser atacada por um bebê faminto. Esses dois fenômenos não estabelecem uma relação entre si até que a mãe e o bebê vivam juntos uma experiência. A mãe, sendo madura e fisicamente capaz, deve ser a parte que tolera e compreende, sendo ela, portanto, quem produz uma situação que, com sorte, pode resultar no primeiro vínculo estabelecido pelo bebê com um objeto externo, um objeto que é externo ao eu do ponto de vista do bebê. (Winnicott, 1945/2000, p. 227, grifado no original).

É a superposição dessas duas linhas de direções opostas aquilo que cria o momento de ilusão - a alucinação do bebê de algo que pode ser atacado (o seio) é enriquecida pela experiências sensoriais, o que deverá colaborar para a construção de alucinações futuras. Dessa forma a alucinação do bebê passa a aproximar-se cada vez mais daquilo que está de fato ao seu alcance, o que depende da confiabilidade proporcionada pelo ambiente. Winnicott (1945/2000) destaca a importância da monotonia do cuidado materno, o quanto esse processo é facilitado por esse tipo de repetição, mas, na realidade, trata-se de algo que transcende uma monotonia - a característica fundamental desse tipo de relação é a previsibilidade. O autor (1963a/1983) declara que a capacidade de compreensão da realidade pode ser postergada por uma confusão na maneira irregular com que ela é apresentada. Percebemos, assim, que o papel do ambiente na circunstância da realização é a apresentação dos objetos, uma forma de trazer ao bebê o mundo em um formato limitado, compreensível e previsível, de maneira que a criança possa gradualmente, a partir desse encontro, atingir a separação e o reconhecimento do mundo externo. Joyce \& Caldwell resumem o processo de realização da seguinte forma:

\begin{abstract}
Adaptação à realidade presume integração, mas estar consciente da realidade envolve primeiramente as relações objetais do indivíduo no mundo criado da fantasia dependente da ilusão. Só então uma troca corrente entre fantasia e realidade pode ser apreciada e aproveitada juntamente a uma consciência da realidade externa. $\mathrm{O}$ mundo, seus prazeres e suas frustrações devem ser trazidos ao bebê de forma compreensível. Essa é a tarefa da maternagem comum. (Joyce \& Caldwell, 2011, p. 56)
\end{abstract}

Percebemos, dessa maneira, que o estágio de dependência relativa consiste, como Winnicott nos diz, em "um estágio de adaptação a uma falha gradual dessa mesma adaptação" (Winnicott, 1963a/1983, p. 83), isto é, da progressiva tomada de consciência de que o ambiente existe como algo separado de si, o que implica no reconhecimento da dependência em relação a esse mesmo ambiente. Evidentemente, esta desilusão somente pode ocorrer se uma ilusão tiver se estabelecido antes de modo suficiente. 
Embora o nível da dependência relativa pressuponha uma complexidade maior no que se refere à organização subjetiva, bem como uma maturidade emocional mais avançada, devemos salientar o papel desempenhado pelo ambiente ao longo de todo o desenvolvimento do indivíduo. Sua função é facilitar a maturação, de modo que a tendência ao crescimento pessoal da criança - a continuidade do ser - não seja interrompida. As falhas ambientais são inevitáveis e até certo ponto necessárias, como no caso do processo de desilusão, por meio do qual os crescentes períodos de ausência da mãe acompanhados de seu retorno permitem ao bebê tolerar momentos de solidão e entrar em contato com a realidade. No entanto, quando as falhas são por demais intensas ou repetem-se com demasiada frequência, tanto o desenvolvimento emocional quanto a própria constituição subjetiva alcançada até então são ameaçados. São estes percalços que examinaremos a seguir.

\subsubsection{Os sentidos do trauma em Winnicott}

Ao discorrermos sobre os caminhos percorridos pelo sujeito ao longo de seu desenvolvimento emocional, percebemos que o âmago do processo não se refere ao sujeito, mas à relação sujeito-ambiente como um todo - como nos recorda Lejarraga (2008), uma relação entre um indivíduo dotado de uma tendência inata para o desenvolvimento e um ambiente incumbido da tarefa de facilitador. Consequentemente, a ótica winnicottiana não poderia considerar o trauma como um fenômeno unipessoal, pelo contrário, assim como os autores trabalhados até aqui Ferenczi e Balint -, Winnicott o concebe como algo pertencente ao âmbito das relações interpessoais. Trata-se de um fracasso que concerne à dependência - seja uma impossibilidade de estabelecimento ou a quebra da confiabilidade do ambiente - , o que interrompe a continuidade do ser.

A questão da confiabilidade, também da mesma forma que nas visões ferencziana e balintiana, assume protagonismo na construção winnicottiana acerca do trauma. Segundo Dias (2006), é a confiança a condição ambiental que deveria existir de forma que se prevenisse o trauma. Seu significado é

[...] basicamente, que a pessoa que é 'ambiente' (mãe ou substituta) - ou seja, que assume o lugar de quem cuida -, reconhece e respeita as necessidades do 
indivíduo dependente e que os cuidados a serem fornecidos são orientados pelas necessidades do indivíduo dependente e não pelas necessidades ou impulsos do ambiente (mãe). Isso é verdadeiro em qualquer idade sempre que uma dependência, de qualquer nível, se faz presente" (Dias, 2006, p. 1)

É importante, neste momento, destacar a última frase da citação acima. Ela nos mostra que o trauma, para Winnicott, não remete a um fenômeno exclusivamente primitivo, podendo ocorrer com efeito desestruturante ao longo de qualquer momento da vida. No entanto, quanto mais inicial for o momento (e mais dependente for o sujeito em relação ao ambiente), maior será a importância da confiabilidade.

A partir do artigo de Winnicott publicado em 1965, O conceito de trauma em relação ao desenvolvimento do indivíduo dentro da família, Dias (2006) descreve cinco classificações do trauma relativas ao estágio de desenvolvimento no qual o indivíduo se encontra. A mais avançada delas está relacionada à capacidade do sujeito de sentir ódio, um ódio dirigido ao objeto bom devido à súbita intrusão de um fato real - uma decepção que prejudica a pureza da experiência individual. O resultado desse tipo de trauma é o amargor, uma perda de esperança na humanidade, o que é vivenciado através da projeção do seu próprio ódio para fora, estabelecendo um aspecto paranoide da personalidade.

O quarto dos significados de trauma se refere a uma etapa na qual o indivíduo já é uma pessoa inteira que se relaciona com pessoas inteiras - o que indica que o desenvolvimento emocional primitivo transcorreu com certo sucesso. Dias (2006) considera que nesse momento a criança está saudável o bastante para adquirir uma neurose, no caso de as tensões instintivas serem demasiadamente elevadas e o ambiente não proporcionar a estabilidade necessária. Nesse caso, o trauma promove um sofrimento, mas o sujeito não corre o risco de ser aniquilado.

O terceiro nível do trauma é relativo à deprivação - a criança foi cuidada por uma mãe suficientemente boa e conquistou certa diferenciação entre si e o ambiente, mas subitamente essa provisão ambiental é perdida, abalando a confiabilidade que existia até então. Dias nos recorda que essa situação é traumática se ainda não existe a possibilidade de defesa através do ódio; nesse caso, o que acontece é a perda de fé característica da tendência antissocial (Winnicott, 
1956a/2000), a partir da qual a criança passa a cobrar do mundo a perda de algo que lhe é tão precioso.

A segunda classificação do trauma diz respeito aos estágios de dependência relativa, durante a qual, como discutimos anteriormente, a mãe está lidando com o processo de desilusão do bebê - o que se reflete no exemplo do desmame. No caso, o trauma é gerado pela ausência de um determinado tipo de falha - as falhas graduais que a mãe introduz junto ao bebê em seu processo de desadaptação. Trata-se de uma atitude paradoxal de parte do ambiente, na qual sua adaptação às necessidades do bebê encontra-se justamente em sua capacidade em se desadaptar. No entanto, essa desilusão envolve uma comunicação empática através da qual a mãe percebe as possibilidades do bebê em tolerar essas falhas, de forma que essa capacidade não seja excedida.

O mais primitivo dos níveis do trauma (e aquele do qual Winnicott mais se ocupou em sua obra) se refere à dependência absoluta, momento em que o significado do trauma é de um colapso da confiabilidade do ambiente: "Nesse estágio, o fracasso da confiabilidade deve-se a um fracasso da adaptação ambiental, ao fato de o ambiente falhar em comunicar-se, em reconhecer ou deixando repentinamente de reconhecer as necessidades da dependência. Ao invés de confiável [...], o ambiente comporta-se de maneira caótica, imprevisível e pouco sensível às necessidades do indivíduo dependente" (Dias, 2006, p. 2). O caos representa um tema de grande interesse de parte de Winnicott, como podemos notar na seção que lhe é dedicada no livro postumamente publicado Natureza humana.

Nesse trabalho, o autor postula que é impossível falar sobre caos no princípio, isto é, nos estado de não integração primária - a presença do caos exige uma noção de ordem que ainda não existe, da mesma forma que não se pode falar em escuridão sem que exista uma ideia de luz. O caos surge apenas em um momento posterior, como um caminho descrito pela perda da ordem (da integração), ou seja, pela desintegração: “O caos adiciona a si mesmo um novo sentido ao referir-se à ordem que chamamos de integração. A não-integração, o estado primário, não é caótica. A desintegração, sim, é caótica, pois representa uma alternativa para a ordem, e podemos dizer que ela é uma organização defensiva grosseira, uma defesa contra as ansiedades trazidas pela integração" (Winnicott, 1988/1990, p. 157). 
Ademais, devemos frisar a essência caótica do trauma advindo do ambiente que fracassa em sua tarefa de adaptação ao indivíduo. De acordo com o autor:

O caos aparece pela primeira vez na história do desenvolvimento emocional através das interrupções reativas do ser, especialmente quando tais interrupções são longas demais. O caos é, primeiramente, uma quebra na linha do ser, e a recuperação ocorre através de uma revivência da continuidade; se a perturbação ultrapassa um limite possível de ser tolerado, de acordo com as experiências anteriores de continuidade do ser, ocorre que devido às leis elementares da economia, uma quantidade de caos passa a fazer parte da constituição do indivíduo. (Winnicott, 1988/1990, p. 157)

O fragmento acima contém algumas ideias interessantes, dignas de reflexão. Ao sugerir que o caos advém de uma situação na qual a comoção ultrapassa um certo limite estabelecido pela constituição subjetiva prévia, Winnicott retoma um preceito ferencziano, segundo o qual o trauma é vivenciado como tal quando excede a capacidade de elaboração da criança, conforme discutido no capítulo anterior do presente trabalho. O segundo ponto a se destacar diz respeito às interrupções reativas do ser. De acordo com a teoria elaborada por Winnicott, assim como todo o desenvolvimento saudável, o trauma se desenrola em uma dimensão relacional. Ele não se resume, portanto, à falha (ainda que intensa) do ambiente. O trauma winnicottiano é construído, portanto, por um conjunto que envolve tanto uma intrusão de parte do ambiente quanto a reação do indivíduo evocada por essa invasão. Devemos salientar que essa falha não é necessariamente ruidosa, pode ocorrer de forma sutil, como através da incapacidade da mãe de exercer a função de espelho ao não conseguir refletir sua identificação com o bebê, como nos sugere Lejarraga (2008).

Enquanto o ambiente encontra-se ativamente adaptado às necessidades do bebê, sua continuidade do ser é preservada, sendo possível guiar-se pelo gesto espontâneo. No entanto, quando é necessário reagir às falhas ambientais, o sujeito está agindo de acordo com a expectativa gerada pela atitude do ambiente, abandonando assim, ainda que por alguns instantes, seu padrão pessoal. Por isso, a reação às intrusões ambientais envolve uma perda temporária de identidade: "Quando o ambiente falha na adaptação ao bebê, este tem de se adaptar ao ambiente, reagindo à intrusão, o que implica uma perda de espontaneidade e uma quebra na sua continuidade do ser" (Lejarraga, 2008, p. 129). Dessa forma, o aspecto 
traumático da intrusão corresponde à imposição de uma experiência ao bebê que o leva a reagir ao invés de simplesmente ser.

A forma com que essa quebra da continuidade do ser é experienciada pela criança é através do que Winnicott chama de "agonia impensável" - algo que não pode ser nomeado, pensado, representado ou integrado no self e que ameaça a própria existência: “As agonias impensáveis são, assim, angústias psicóticas que dizem respeito ao ser: a ameaça não é, como na angústia de castração, a perda da onipotência narcísica, mas o aniquilamento do ser, já que o bebê interrompe seu vir-a-ser quando reage" (Lejarraga, 2008, p. 130). Davis \& Wallbridge (1981/1982) listam os seguintes exemplos de agonias impensáveis descritas por Winnicott, sintetizando as propostas do autor em 1962 e 1968: (1) despedaçar-se; (2) cair para sempre; (3) não ter relação com o corpo; (4) não ter orientação; e (5) isolamento completo porque não existem meios de comunicação. Ou seja, se trata de angústias relativas ao desenvolvimento emocional primitivo, nos sentidos de integração, personalização e realização. É interessante considerar, a este respeito, que o pensar é comumente associado à atividade intelectual, calcado na linguagem - algo certamente mais complexo e avançado do que o momento no qual se desenvolvem as angústias que Winnicott está descrevendo. Essa ideia possui importantes repercussões para a clínica e parece justificar a afirmação de Winnicott (1962a/1983), segundo a qual essas angústias primitivas não seriam analisáveis: como não há linguagem envolvida, a interpretação se mostra ineficaz em acessálas. Não se pode lembrar de algo pela linguagem, pelo pensamento, se o próprio pensamento não estava presente no momento.

Ainda que as falhas ambientais mais expressivas certamente representem um grande problema ao ainda imaturo aparelho psíquico do bebê, suas repercussões são grandemente intensificadas de acordo com a frequência com que ocorrem sem que o ambiente seja capaz de preservar o ego infantil:

Pode-se dizer que uma proteção do ego suficientemente boa pela mãe (em relação a ansiedades inimagináveis [ou agonias impensáveis]) possibilita ao novo ser humano construir uma personalidade no padrão da continuidade existencial. Todas as falhas que poderiam engendrar a ansiedade inimaginável acarretam uma reação da criança, e esta reação corta a continuidade existencial. Se há recorrência da reação desse tipo de modo persistente, se instaura um padrão de fragmentação do ser. A criança cujo padrão é o de fragmentação da continuidade do ser tem 
uma tarefa de desenvolvimento que fica, desde o início, sobrecarregada no sentido da psicopatologia. (Winnicott, 1962a/1983, p. 59)

A fragmentação do ser mencionada por Winnicott corresponde à cisão, uma defesa presente em qualquer pessoa (Winnicott, 1988/1990) ainda que em variados níveis, não devendo ser necessariamente significativa - apenas o é quando a adaptação ativa suficientemente boa do ambiente se faz ausente. Os elementos cindidos são dois, nomeados por Winnicott como verdadeiro self e falso self.

O verdadeiro self está ligado à ideia de processo primário, sendo, portanto, não reativo aos estímulos externos. Trata-se, segundo Winnicott, da "posição teórica de onde vem o gesto espontâneo e a ideia pessoal. O gesto espontâneo é o self verdadeiro em ação. Somente o self verdadeiro pode ser criativo e se sentir real" (Winnicott, 1960b/1983, p. 135). O verdadeiro self corresponde, destarte, à porção mais genuína da personalidade.

É justamente essa espontaneidade que se perde quando o padrão pessoal passa a se basear nas reações às intrusões do ambiente. No caso, o falso self assume protagonismo na personalidade, eclipsando o verdadeiro self, o que evoca um sentimento de irrealidade e futilidade. É pertinente, contudo, ressaltar a importante função defensiva exercida pelo falso self - é a sua atuação, submissa e adaptada ao ambiente, o que protege o verdadeiro self da possibilidade de aniquilação em situações extremas.

Winnicott (1960b/1983) descreve diferentes organizações de falso self, de acordo com a sua predominância. Em um extremo, o falso self se apresenta como a totalidade da pessoa, enquanto o verdadeiro permanece absolutamente oculto. Obviamente, as relações estabelecidas pelo falso self começam a mostrar-se falhas, uma vez que carecem de significância. No outro lado, mais próximo da saúde, o falso self ainda se faz presente, mas na atitude social polida, por exemplo, de maneira que o verdadeiro self seja não apenas preservado, mas também permitido: "O falso self, se bem sucedido de sua função, oculta o self verdadeiro ou então descobre um jeito de possibilitar ao self verdadeiro começar a existir" (Winnicott, 1960b/1983, p. 135).

Percebemos, dessa maneira, que o trauma no nível da dependência absoluta implica em uma perda de identidade oriunda da ação do falso self. A 
imprevisibilidade do ambiente mantém essa defesa em funcionamento, o que perpetua um estado de alerta, de sobressalto, à espera de que a falha se repita existe, portanto, uma apreensão de que as agonias impensáveis possam ocorrer novamente. Essa constante apreensão impede que o sujeito alcance uma condição de relaxamento, isto é, impossibilita o retorno saudável aos estados não integrados. Segundo Greenberg \& Mitchell, "A principal consequência de intromissão prolongada é a fragmentação da experiência do bebê. Por necessidade, ele se torna prematura e compulsivamente sintonizado às reivindicações e pedidos dos outros. Ele não pode se permitir a experiência da tranquilidade sem-forma, uma vez que deve estar preparado para responder ao que lhe é pedido e fornecido" (Greenberg \& Mitchell, 1983/1994, p. 143). Do mesmo modo, essa imprevisibilidade por parte do ambiente torna muito difícil para o bebê a tarefa de se temporalizar. O ambiente suficientemente bom proporciona à criança uma monotonia que permite a experiência de um passado e a projeção de um futuro - ao precisar reagir o tempo todo ao imprevisível, existe uma contínua tarefa de começar de novo. De acordo com Dias: "Começar tudo de novo é estar privado da raiz pessoal e da espontaneidade; é não poder juntar experiências, não formar passado, não poder projetar o futuro, não adquirir a crença num mundo encontrável e perdurável; é dispersar-se num presente eterno, em que a luta para nunca mais sofrer a agonia impensável priva o indivíduo da liberdade de deixar acontecer, de recepcionar acontecimentos" (Dias, 2006, p. 6, grifo meu). Esse tipo de comoção resulta em uma incapacidade de elaboração do trauma, sendo este vivenciado o tempo todo no presente, sem poder tornar-se passado - algo bastante evidente no discurso de muitos pacientes.

Posso brevemente ilustrar essa situação através do caso de um paciente que atendo, por volta dos quarenta anos, cuja mãe sofreu um grave acidente com a explosão de um botijão de gás enquanto estava grávida dele (ainda que, ao menos fisicamente, tivesse sido constatado que o bebê nada sofreu). A queixa principal trazida por ele e que o levou à busca da análise, é um permanente estado de tensão, especialmente ao sair na rua - mais do que o medo de que algo aconteça, é a certeza de que algo vai acontecer. É certo que este trauma foi agravado por experiências infortunas ao longo de sua infância (rompantes silenciosamente agressivos de um pai instável), mas devemos considerar a influência de um trauma tão primitivo e 
intrusivo. É interessante ainda ponderar que, em paralelo a esse estado de alerta, a revivência constante dessa expectativa (e, consequentemente, dessa intrusão) se reflete de certa forma em sua escolha profissional - trabalha em um laboratório, um ambiente altamente intelectualizado no qual acidentes são comuns, envolvendo, inclusive, explosões. Seria possível considerar essa escolha uma coincidência ou um acaso da vida, mas é difícil seguir esse caminho. Me parece que essa escolha indica uma tentativa de representar essas experiências traumáticas precoces ao viver (e não reviver) continuamente, de certa forma, a situação traumática.

Tendo levantado, até esse momento, as teorias de Ferenczi, Balint e Winnicott sobre como se estabelecem as situações traumáticas e suas repercussões para o desenvolvimento individual, seja ele patológico ou não, devemos nos ocupar agora da forma com que esses autores constroem suas propostas clínicas para lidar com esse tipo de experiência. 


\section{A clínica do trauma - regressão no setting psicanalítico}

Foi possível perceber, ao longo dos capítulos anteriores, que os três autores que fundamentam esta tese até aqui se interessaram por um tipo bastante particular de paciente. Trata-se de pessoas com as quais as técnicas clássicas, de interpretações que remetem a conflitos edipianos (relativos, portanto a relações entre pessoas totais), revelam-se falhas, insuficientes e, acima de tudo, temerárias. Como as questões de seus pacientes reportavam a momentos iniciais da vida - situações traumáticas primitivas - Ferenczi, Balint e Winnicott propuseram uma grande revisão, tanto da teoria quanto da técnica psicanalítica, na tentativa de adaptar a clínica de forma que fosse possível abarcar os sofrimentos psicóticos e borderlines.

Embora muitos avanços tenham sido alcançados graças às experiências conduzidas por esses três autores (bem como por aqueles que buscavam uma alternativa na psicanálise para esses pacientes, como Fairbairn), é notável a crítica quanto a esse tipo de método ao longo dos tempos - nas reprimendas de Freud às inovações técnicas de Ferenczi que levaram ao rompimento entre os dois; na desaprovação de Lacan exposta em seminário de 1954 às ideias de Balint, classificando as teorias deste como puritanas (Lacan, 1975/1986); e nas críticas de Melanie Klein (sua antiga supervisora) e Joan Riviere (sua segunda analista) a Winnicott, devido às suas contribuições equivocadas - aos olhos das duas - acerca dos fenômenos da primeira infância, como nos revela Rodman (1972/1995) a partir de uma carta de Winnicott a Riviere em 1956. Por outro lado, existe também uma grande celebração a esses três autores, pela sua sensibilidade, percepção e coragem, que os levaram a buscar novos horizontes dentro da clínica psicanalítica.

Devemos agora então explorar algumas das adaptações que esses autores sugeriram à técnica psicanalítica, percorrendo alguns temas de grande relevância para a clínica do trauma, em especial o trauma advindo dos estágios iniciais do desenvolvimento. 


\subsection{O setting psicanalítico}

Não há como negar a importância do setting terapêutico no processo psicanalítico. Assim como o tabuleiro e as regras de um jogo, ou as normas gramaticais de um idioma, é o setting que torna a relação psicanalítica um fenômeno compartilhado, objetivo e subjetivo. Mais do que isso, é ele que dá forma à terapia, o que a situa no tempo e no espaço, através de um conjunto de determinações relativas, por exemplo, ao lugar em que a análise ocorre, ao horário da sessão, aos objetos que compõem o consultório e até mesmo à postura do analista. David Zimerman (2004) propõe que "[...] o setting resulta de uma conjunção de regras, atitudes e combinações, tanto as contidas no 'contrato analítico' [...] como também aquelas que vão se definindo durante a evolução da análise, como os dias e horários das sessões, os honorários com a respectiva modalidade de pagamento, o plano de férias, etc." (Zimerman, 2004, p. 67), lembrando, no entanto, que essas regras devem ser definidas não a partir de uma imposição do analista, mas em um acordo com o paciente. José Bleger (1967/1988) aprofundaria essa ideia ao afirmar que há dois settings que coexistem: aquele que é proposto pelo analista e conscientemente aceito pelo paciente; e um outro advindo do "mundo fantasma" que o paciente inconscientemente projeta nessa relação.

Por outro lado, Bleger (1967/1988), baseado nos preceitos de Winnicott (1956b/2000), sugere ainda que o setting corresponde à soma de todos os detalhes da técnica, o que inclui uma dimensão constante - o não processo - constituído pelo que o autor chama de enquadramento (os aspectos formais e invariáveis do setting), um fundo silencioso, mudo; e uma variável - o processo - referente ao objeto de estudo, à análise e às interpretações. Ainda assim, Bleger ressalta que o enquadre deve comportar uma certa maleabilidade, o que o torna especialmente importante na análise de pacientes regredidos, em uma referência à ideia de meio maleável trabalhada por Marion Milner (1952), segundo a qual o setting deve permanecer indestrutível, disponível e vivo - como a água, podemos afirmar.

Milner foi uma importante psicanalista na Sociedade Britânica de Psicanálise, aliada de Melanie Klein até 1954, quando rompeu com sua antiga supervisora devido à sua discordância quanto à ideia de inveja inata, passando a integrar então o grupo independente. Milner era pintora e grande entusiasta do uso 
da arte como ferramenta terapêutica, e nos ofereceu uma interessante contribuição ao discutir as técnicas que utilizava para pintar e relacionar o espaço da tela ao setting, percebendo que o espaço limitado da tela em branco proporcionava uma tendência organizadora dos conteúdos internos - a partir daquele espaço, em que tanto o interno quanto o externo são delimitados, era possível começar com alguma coisa. Ao contar, em um texto de 1952, suas experiências em uma palestra ministrada na Universidade de Leeds (exposição esta que nunca teria sido transcrita), Milner nos oferece uma interessante concepção sobre o enquadramento psicanalítico a partir de reflexões sobre a função da moldura, evocando a participação da plateia nesse processo. Segundo Milner:

Eu disse a eles que via a moldura como algo que diferenciava o que estava dentro dela daquilo que estava fora, e para que pensassem em outras atividades humanas em que a moldura é essencial, uma moldura tanto no tempo quanto no espaço; por exemplo, a peça encenada, cerimônias, rituais, procissões, até poemas emoldurados no silêncio quando declamados e o espaço do papel quando escrito. (Milner, 1952, p. 60)

Ao comentar essas considerações de Milner sobre a função da moldura no quadro pintado, Masud Khan (1960/1977) oferece uma definição bastante clara e interessante do conceito de setting, como algo que delimita a realidade espaçotemporal da sessão analítica, possibilitando a transferência:

A moldura $(\text { frame })^{2}$ delimita o tipo de realidade diferente que está dentro dela da que está fora; mas uma moldura (frame) especial temporal também delimita o tipo de realidade especial de uma sessão psicanalítica. E na psicanálise, é a existência dessa moldura (frame) que torna possível o completo desenvolvimento da ilusão criativa que os analistas chamam de transferência. (Khan, 1960/1977, pp. 169-170)

Trata-se, portanto, de proporcionar um espaço dinâmico através do qual o paciente possa expressar sua subjetividade, assim como se oferece uma folha de papel para que uma criança desenhe sobre ela. O setting representa, então, um ambiente ativamente adaptado às necessidades do paciente, levando em consideração sua estrutura psíquica singular, de forma que seja possível estabelecer um campo de reprodução e atualização de experiências emocionais através do vínculo transferencial. Zimerman está de acordo com essa ideia, ao declarar:

\footnotetext{
${ }^{2}$ Devemos destacar que o termo "frame", aqui traduzido como moldura, comportaria ainda traduções como quadro ou enquadramento.
} 
O relevante a destacar é que o setting não se deve comportar como uma situação meramente formal e passiva. Pelo contrário, ele tem uma função bastante ativa e determinante na evolução da análise, serve de cenário para a reprodução de velhas e novas experiências emocionais, além de estar sob uma contínua ameaça em vir a ser desvirtuado tanto pelo analisando quanto também pelo analista, em função do impacto de contínuas e múltiplas pressões de toda ordem. (Zimerman, 2004, p. 67)

Para que essas necessidades sejam atendidas, pode ser fundamental que o setting suporte um retorno a uma sorte de relação objetal de natureza especialmente primitiva, o que pode ser visto com clareza nos fenômenos regressivos. No entanto, devemos salientar que nestes casos o analista não deverá desempenhar propriamente uma função de mãe substituta, mas a de um ambiente que oferece novas condições de maternagem.

Embora tenha discorrido exaustivamente sobre seu trabalho com crianças, Winnicott desenvolveu uma clínica muito sólida com adultos, especialmente nos casos em que, a seu ver, a técnica clássica freudiana fracassaria. Como já apresentado anteriormente nesta tese, tais indivíduos traziam questões muito primitivas, anteriores à possibilidade de relações edípicas. Assim, a formulação de interpretações poderia não surtir qualquer efeito terapêutico, pelo contrário, essas intervenções poderiam ser vivenciadas pelo paciente como um ataque, uma invasão. Esse tipo de paciente exigiria uma postura diferente do analista, trazendo a ênfase do trabalho clínico para o espaço relacional, e não para o intrapsíquico. A respeito desse novo tipo de trabalho analítico, Winnicott declara:

No trabalho que estou descrevendo, o contexto [setting] torna-se mais importante que a interpretação. A ênfase é transferida de um aspecto para o outro. $\mathrm{O}$ comportamento do analista, representado pelo que chamei de contexto, por ser suficientemente bom em matéria de adaptação à necessidade, é gradualmente percebido pelo paciente como algo que suscita a esperança de que o verdadeiro eu poderá finalmente correr os riscos implícitos em começar a experimentar viver. (Winnicott, 1956b/2000, p. 395, grifo meu)

Balint também considerava que boa parte do universo de sua clínica era composta por indivíduos cuja problemática remetia a situações precoces, para as quais a técnica clássica poderia ser considerada limitada. Todavia, algum nível de regressão sempre se faria presente, fosse ao âmbito edipiano, em que o trabalho interpretativo tradicional seria o mais adequado, ou ao nível da falha básica, em que um trabalho diferenciado se faria necessário. 
Ao pensarmos sobre o setting, é importante considerar a adaptabilidade do analista. Este precisa flexibilizar-se de modo que esteja oferecendo aquilo de que o paciente necessita. Winnicott afirma: "Gosto de fazer análise e sempre anseio pelo seu fim. A análise só pela análise para mim não tem sentido. Faço análise porque é do que meu paciente necessita. Se o paciente não necessita análise, então faço alguma outra coisa" (Winnicott, 1962b/1983, p. 152). Todavia, isso não quer dizer que o setting deve mudar constantemente: uma vez definido com o paciente, ele precisa ser confiável e estável, da mesma maneira que é preferível para o bebê, segundo Winnicott (1988/1990), que ele seja cuidado por apenas uma mãe, mantendo o ambiente mais regular e menos complexo. Zimerman (2004) chama a atenção para a importância da firmeza do analista (o que deve ser diferenciado de uma rigidez) no cumprimento das regras estabelecidas no acordo com o paciente. É interessante lembrar desde já que a firmeza de Winnicott é recordada como algo de grande relevância (e afeto) justamente por uma de suas pacientes mais difíceis, Margaret Little, ao relatar sua experiência de análise, tal como veremos adiante.

A regularidade do setting e essa firmeza da parte do analista constituem a base para a confiabilidade na relação analítica, proporcionando segurança ao paciente de forma que este saiba que o analista sobreviverá e não retaliará o paciente por seus ataques. Assim o paciente pode manter-se em estado não ansioso, o que permite uma comunicação mais genuína, despreocupada e significativa. De acordo com a teoria de Winnicott, alguns tipos de ansiedade poderiam ser evitados no início da infância por um cuidado suficientemente bom e isto se reflete posteriormente na situação analítica. As vivências persecutórias evocadas pela ameaça de desintegração, intoleráveis quando o ambiente não proporcionou um cuidado adequado, se assemelham às ansiedades vividas pelo paciente quando o setting não é confiável ou previsível.

A confiabilidade representa uma característica fundamental do setting suficientemente bom (ou adequado), não apenas na visão winnicottiana, mas também para Balint e Ferenczi, que a descreve como “[...] aquele algo que estabelece o contraste entre o presente $e$ um passado insuportável $e$ traumatogênico" (Ferenczi, 1933/2011, p. 115, grifado no original). A confiança, portanto, é fundamental para que o passado seja reavivado como lembrança objetiva 
e não como uma reprodução alucinatória. Embora essa ideia já tivesse sido introduzida por Ferenczi no final dos anos 20, tal constatação foi aprofundada pelo autor ainda no fim de sua vida (faleceria em maio de 1933, no mesmo ano de publicação de Confusão de língua entre os adultos e a criança e alguns meses após a apresentação do mesmo trabalho, em setembro de 1932, no Congresso de Wiesbaden) em alusão aos impasses que viveu em decorrência de suas experimentações clínicas, principalmente com o uso da técnica ativa.

Segundo Ferenczi, o fracasso da técnica ativa se deu principalmente devido ao inesperado fator traumático - "tão injustamente negligenciado nestes últimos tempos na patogênese das neuroses" (Ferenczi, 1933/2011, p. 111) - que se fazia presente na situação analítica. Embora houvesse notáveis melhoras de certos sintomas, os pacientes queixavam-se de intensos estados de angústia persistentes, decorrentes de repetições alucinatórias do trauma. Chamou a atenção de Ferenczi a forma com que seus pacientes se referiam a ele: insensível, frio, cruel, egoísta. A autocrítica o levou a perceber que, ao recorrer às determinações da técnica ativa, ocupava o lugar do ambiente original, violento, invasivo e traumático. $\mathrm{O}$ autor se propôs a discutir, então, a atitude do analista nesse contexto, que impossibilitava o estabelecimento de uma relação de confiança, ao sugerir a ideia de hipocrisia profissional:

Acolhemos polidamente o paciente quando ele entra, pedimos-lhe que nos participe suas associações, prometemos-lhe, assim, escutá-lo com atenção e dedicar todo o nosso interesse ao seu bem-estar e ao trabalho de elucidação. $\mathrm{Na}$ realidade, é bem possível que certos traços, externos ou internos, do paciente nos sejam dificilmente suportáveis. Ou ainda, podemos sentir que a sessão de análise gera uma perturbação desagradável numa preocupação profissional mais importante, ou numa preocupação pessoal e íntima. Também nesse caso não vejo outro meio senão tomar consciência do nosso próprio incômodo e falar sobre ele com o paciente, admiti-lo, não só como possibilidade mas também como fato real. (Ferenczi, 1933/2011, pp. 113-114)

Embora essa afirmação de Ferenczi possa parecer, em certo ponto, problemática (já que traz algumas ideias da controversa análise mútua, narrada em seus diários clínicos, quando levou a sinceridade do analista ao extremo), o autor também nos indica uma questão interessante relativa à contratransferência. Ferenczi foi, ao longo de sua obra, um ferrenho defensor da análise pessoal do analista, a fim de que os sentimentos inconscientes instigados pelo discurso do paciente, bem 
como pela relação que este estabelece com o terapeuta, não sejam devolvidos ao analisando de forma bruta.

De qualquer forma, Ferenczi salienta ainda que a hipocrisia profissional age de forma a camuflar o erro do analista, o que gera uma atmosfera insincera: "Na relação entre o médico e o paciente existia uma falta de sinceridade, algo que não tinha sido formulado, e o fato de lhe dar uma explicação soltava, de certo modo, a língua do paciente. Admitir um erro valia ao analista a confiança do analisando" (Ferenczi, 1933/2011, p. 114). Segundo Lejarraga, somente quando o analista renuncia à sua hipocrisia e torna-se capaz de criar esse clima de confiança é possível acessar o trauma do paciente: "Ferenczi percebe que quando o analista é insincero, reproduz-se, no espaço analítico, o ambiente hipócrita infantil. Somente estabelecendo-se um contraste entre a situação analítica atual e o passado infantil traumatogênico, é possível chegar aos restos do eu infantil, quase morto, revivendo a dor do trauma" (Lejarraga, 2008, pp. 123-124). Como nos mostraria no Diário clínico, Ferenczi considera que os erros do analista são inevitáveis - ao comentar o caso de R. N., abordado no primeiro capítulo desta tese, o autor (1985) considera que a existência da falha analítica quer dizer que o analista não é capaz de oferecer todos os cuidados maternos. O que marca a diferença é que, nessa nova situação, esses erros não devem ser negados (ou desmentidos) como foram outrora.

Winnicott (1956b/2000) parece concordar com essa ideia, ao afirmar que o paciente regredido deve poder fazer uso da falha do analista. Essas falhas, segundo o inglês, são inevitáveis, já que é impossível proporcionar uma adaptação perfeita ao paciente. Ao discorrer sobre o efeito gerado pelo erro do analista, Winnicott sugere:

A chave para compreendê-lo é a de que a falha do analista está sendo usada e deve ser tratada como uma falha antiga, que o paciente pode agora perceber e abarcar, e zangar-se por isso. O analista deve ser capaz de usar suas próprias falhas em termos de sua significação para o paciente, sendo necessário que ele assuma a responsabilidade sobre cada uma delas, mesmo que isto implique em examinar sua contratransferência inconsciente. (Winnicott, 1956b/2000, p. 397)

Para Winnicott, é essa parte do trabalho que liberta o paciente de sua dependência em relação ao analista, já que é possível, pela primeira vez, sentir raiva pelas falhas de adaptação que outrora foram vivenciadas como rupturas. No entanto, Ferenczi (1933/2011) reforça a ideia de que essas falhas, cuja explanação lhe parece 
tão benéfica para o paciente, não devem ser provocadas, mas fazer parte do processo analítico natural, como lhe lembrou uma paciente, ao dizer-lhe que seria preferível que ele evitasse todos os seus erros.

Em oposição à hipocrisia profissional, Ferenczi (1930/2011) sugere uma atitude amistosamente benevolente e sincera da parte do analista que proporcione uma comunicação real entre ele e o paciente - afinal, enquanto o erro não é reconhecido, permanece algo que não é dito, que é impossível de ser, portanto, representado, da mesma forma que na situação traumática no tempo do desmentido, tal como exposto no primeiro capítulo desta tese.

Assim como Ferenczi, Balint atribuía grande importância quanto ao estabelecimento desse tipo de relação. $\mathrm{O}$ autor, notoriamente influenciado por Ferenczi, descartou o uso da técnica ativa e da análise mútua em sua prática, em favor de uma abordagem mais segura e eficaz (Gelly, 1982/1994) representada pela criação de um clima relacional de segurança, no qual o analista se apresenta no setting como um objeto primário que não oferece resistência - "desta forma, o analista permite que o paciente experimente com ele uma espécie de interpenetração harmoniosa, como aquela que é vivida com as substâncias primárias no período primitivo das relações do sujeito com seu ambiente" (Peixoto Junior, 2013, pp. 6465). A atmosfera estabelecida nesse contexto é chamada por Balint de arglos, palavra alemã que, embora não possua uma tradução direta, se aproxima do significado de sincero, franco, ingênuo - ideia que possui muito em comum com o que foi sugerido por Ferenczi em sua crítica à hipocrisia profissional. Segundo nos diz Balint, para traduzir sua ideia a partir do conceito de arglos é necessária "[...] uma palavra que descreve a constelação na qual um indivíduo sente que nada de perigoso no ambiente lhe é direcionado e, ao mesmo tempo, nada de perigoso nele é direcionado ao ambiente" (Balint, 1969, p. 135). Somente a partir dessa relação de confiança mútua é possível, para o paciente viver a oportunidade de um novo começo.

Percebemos, assim, que a proposta de nossos três autores sobre o setting difere muito daquelas definidas pelos autores mais tradicionais da psicanálise, justamente por estarem lidando com fenômenos diferenciados - como nos diria Ferenczi, trata-se de idiomas distintos. Assim, a maneira de conduzir a análise 
desses pacientes acaba por sofrer, da mesma forma, profundas alterações, o que atinge gravemente tanto a relevância do trabalho interpretativo quanto a forma com que os fenômenos transferenciais são encarados no setting.

\subsection{As formas de transferência}

Em 1905, ao discutir as complicações surgidas no caso Dora, Freud oferece uma formulação do conceito de transferência, como uma doença artificial surgida em decorrência do processo analítico:

Que são transferências? São novas edições, reproduções dos impulsos e fantasias que são despertados e tornados conscientes à medida que a análise avança, com a substituição - característica da espécie - de uma pessoa anterior pela pessoa do médico. Colocando de outra forma: toda uma série de vivências psíquicas anteriores é reativada, mas não como algo passado, e sim na relação atual com o médico. (Freud, 1905/2016, p. 312)

Trata-se, portanto, de uma relação terapêutica de natureza regressiva, através da qual o sujeito busca a revivescência de situações anteriores no presente do setting. Balint (1933b) faz uso de alguns exemplos cotidianos para descrever a ação da transferência, referindo-se à adoração a objetos que pertenceram a pessoas importantes, como a cartola e as sandálias de John Dalton, exibidas em uma caixa de vidro em Manchester; e até mesmo lembrando uma piada, na qual um sujeito, ao surpreender-se com a traição de sua esposa com seu sócio no sofá de sua casa, se depara com um dilema: se pedir o divórcio à esposa, precisa devolver o dote, se desfizer a sociedade, terminará falido. Após uma longa hesitação, decide jogar fora o sofá. O autor conclui, a partir desta anedota:

A causa [da transferência] é sempre a circunstância de que (naquele momento) a emoção não pode ser vivenciada sobre a pessoa ou objeto original ou nem mesmo vivenciada de forma alguma. [...] O mesmo ocorre quando a pessoa original está morta ou distante. Algumas vezes a pessoa original, mas um outro sentimento, como medo, compaixão, amor, etc., nos impede de fazer com ela o que gostaríamos de fazer. (Balint, 1933b, p. 177, grifado no original)

O mesmo deslocamento ocorre no contexto analítico, o que inclui uma miríade de afetos originários que são revividos e direcionados ao analista. Embora, nos primórdios da psicanálise, a transferência fosse encarada como um mero inconveniente a ser evitado (como uma forma de resistência), foi principalmente a partir do trabalho de Freud com Dora que seu papel potencialmente terapêutico passou a ser explorado - ideia que seria mais bem alicerçada em $A$ dinâmica da 
transferência, de 1912, quando ele avança com sua concepção de transferência no sentido da repetição. Essa relação poderia ser estabelecida então sob dois aspectos - um relativo à transferência de sentimentos infantis ternos sobre a pessoa do analista, denominada de transferência positiva; e outro relacionado aos sentimentos hostis depositados sobre ele, chamado de transferência negativa. De acordo com Kupermann (2008), a transferência positiva consistiria no maior dos aliados do tratamento: "Através dela, o analista pode reconhecer o investimento do analisando no doloroso processo terapêutico, bem como adquirir a influência necessária para a efetividade das suas intervenções" (Kupermann, 2008, p. 77). Por outro lado, a transferência negativa (assim como a transferência positiva erótica) representaria um considerável entrave para o trabalho analítico, algo que seria reafirmado de forma aproximada por Balint (1969), quando este discute a noção de regressão maligna, como veremos adiante.

Embora tenha desenvolvido bastante o tema da transferência positiva em seus trabalhos, Freud recebeu algumas críticas por ter negligenciado em certo ponto o manejo da transferência negativa na análise. Ferenczi foi um dos que manifestou sua desaprovação, salientando a ineficácia de Freud ao analisar os aspectos negativos da transferência enquanto foi seu analista, como nos revela Bokanowski (2000/2000).

Ferenczi, por outro lado, foi um grande entusiasta da exploração da dinâmica da transferência negativa. Após vivenciar o fracasso da técnica ativa e da elevação artificial da tensão pulsional - o que acabava por gerar mais um retraimento análogo ao da criança traumatizada diante do ambiente hostil - Ferenczi percebeu na elasticidade da técnica uma oportunidade para a elaboração das manifestações agressivas do paciente. De acordo com Kupermann, “[...] se o analista se dispuser a ser usado como um ‘joão-teimoso', e se oferecer como suporte das mais intensas manifestações afetivas previstas pela transferência, será recompensado com o ultrapassamento de muitas das 'resistências objetivas' impostas pelo tratamento-padrão" (Kupermann, 2008, p. 82). A ideia, nesse sentido, é que o analista deve ser capaz de suportar a agressividade do paciente, não como uma rocha, mas como uma tira elástica, devendo "[...] ceder às tendências do paciente, mas sem abandonar a tração na direção de suas próprias opiniões, 
enquanto a falta de consistência de uma ou outra dessas posições não estiver plenamente provada" (Ferenczi, 1928/2011, p. 37). Balint (1933b) estaria de acordo com essa ideia, ao declarar que o analista deve conservar uma passividade elástica, sem apresentar qualquer coisa a partir de seu lado da relação terapêutica de forma que seja o paciente quem a desenvolva. Somente assim seria possível permitir o surgimento das manifestações transferenciais do paciente e segui-las. Kupermann chama a atenção então para as consequências do emprego da técnica elástica utilizada por Ferenczi, que se revelavam em "processos regressivos intensos, nos quais as formas de expressão apresentadas se aproximavam das de crianças, tanto em sua dimensão lúdica, quanto em sua dimensão de dor traumática" (Kupermann, 2008, p. 82). Essa ideia seria mais bem desenvolvida por Ferenczi no artigo de 1931, Análises de crianças com adultos, quando o autor sugere que se deva falar na situação analítica com a criança presente no adulto, e não falar, simplesmente, sobre a mesma.

Winnicott se dispôs a percorrer caminho semelhante no que tange à sua visão sobre a transferência. O autor inglês (1956b/2000) levantou uma crítica à forma com que os psicanalistas clássicos selecionavam seus pacientes - apenas poderiam ser submetidos à análise aqueles que tiveram um cuidado suficientemente bom, podendo o analista considerar os estágios iniciais do estabelecimento do ego como um fato já satisfatoriamente consumado. Winnicott, por outro lado, como já exposto anteriormente, se ocupava de pacientes borderlines acometidos de severas angústias primitivas - embora não deixasse de realizar um trabalho no sentido mais tradicional da psicanálise, a partir de materiais edipianos, sempre que necessário. Ao discutir as formas clínicas da transferência, ele justifica a forma com que percebe a dinâmica transferencial com pacientes regredidos:

Esse trabalho amplia o conceito de transferência pelo fato de na análise dessas fases não ser possível considerar o ego uma entidade estabelecida. Não pode, então, existir também a neurose de transferência, para a qual certamente é preciso que haja um ego, e na verdade um ego intacto, capaz de manter defesas contra a ansiedade derivada dos instintos - e de assumir a responsabilidade pelas mesmas. (Winnicott, 1956b/2000, p. 394)

Devemos destacar, no entanto, algumas questões que Winnicott indica no fragmento acima. Primeiramente, o autor destaca que o estabelecimento do ego um sujeito íntegro, delimitado, capaz de estabelecer relações com objetos totais - 
não é um fato, o que remete a momentos que precedem e perpassam o desenvolvimento emocional primitivo. Nesses casos não faria sentido, portanto, que o material analítico se concentrasse em conflitos edipianos, já que pode ser que tais embates nem mesmo cheguem a ser percebidos, em algumas situações. Em segundo lugar, Winnicott declara que, já que não se pode falar em um ego que se relaciona, a neurose de transferência se mostra impossível. Tal afirmação poderia nos levar a uma noção errônea de que, assim como preconizava a psicanálise freudiana, seria impossível realizar um trabalho psicanalítico com pacientes psicóticos e limítrofes, afinal, a transferência constitui a base elementar da análise. Todavia, o que se estabelece nesse contexto é aquilo que Winnicott chama de "psicose de transferência" - relação que fica bastante clara no caso Margaret Little, inclusive através do relato dela mesma.

Devemos ressaltar que Winnicott reconhecia a importância das diferentes técnicas psicanalíticas, desde que fossem dirigidas ao tipo adequado de paciente. A própria Margaret Little seria submetida a uma análise edipiana com Winnicott, após um longo período dedicado à solução de questões relacionais primitivas. Em Aspectos clínicos e metapsicológicos da regressão, de 1954, o autor diferencia três diferentes categorias de pacientes com os quais o analista poderia se defrontar, cada qual podendo ser abarcado por uma técnica diferente, como nos resume Kupermann:

\begin{abstract}
Assim, se para os analisandos que apresentam uma constituição narcísica integrada, cujas dificuldades residem na gestão dos relacionamentos interpessoais, os princípios estabelecidos por Freud para a prática psicanalítica persistiam adequados; para os analisandos cujo sofrimento se refere especialmente ao 'estágio do concernimento' e à aquisição da posição depressiva (recordemos a influência de Melanie Klein sobre a psicanálise da época), o laço transferencial se mostra bem mais delicado, sendo a "sobrevivência do psicanalista" à hostilidade do analisando o elemento privilegiado. (Kupermann, 2008, p. 85)
\end{abstract}

Percebemos, a partir do fragmento acima, que Winnicott se posicionava genuinamente como um integrante do middle group - era capaz de visualizar as valorosas contribuições tanto do grupo freudiano quanto do grupo kleiniano, respectivamente, no campo dos conflitos relativos ao Complexo de Édipo e daqueles referentes à posição depressiva. No entanto, devemos salientar a 
contribuição original do autor inglês sobre as patologias primitivas, representadas no terceiro dos grupos a que Winnicott se refere:

Já para a terceira e última categoria descrita por Winnicott - certamente a mais relevante para suas elaborações teórico-clínicas -, a dos analisandos severamente traumatizados, cuja integração egoica se encontra comprometida, a análise deverá lidar com os estágios iniciais do desenvolvimento emocional primitivo, e a ênfase recairá sobre o 'manejo', o 'trabalho analítico normal deixado de lado por longos períodos', entendendo-se por trabalho 'normal' aquele fundado no princípio de abstinência e na interpretação do recalcado. Tratar-se-ia, nesses casos, de criar as condições de confiabilidade para que a regressão à dependência seja possibilitada. (Kupermann, 2008, p. 85)

É com esses pacientes que se desenvolve a psicose de transferência, situação na qual o analista é experimentado como objeto subjetivo - sua existência como figura real é, em grande parte, ignorada. Enquanto as interpretações perdem importância, ainda que temporariamente, o manejo passa a adquirir um papel fundamental na análise: “Os termos 'manejo' e ‘cuidado' evocam atitudes como as de assistir, proteger, mediar, cuidar, sustentar fisicamente pacientes que regridem a um estado de dependência na análise. A teoria que informa este tipo de abordagem da técnica supõe que se deva criar uma atmosfera adequada, na qual as interpretações possam tornar-se compreensíveis, alcançando verdadeiramente o eu do paciente" (Peixoto Junior, 2013, p. 66). A temporalidade é um importante fator na psicose de transferência, principalmente ao considerar que esse sujeito não foi capaz de integrar-se o suficiente: "Uma das características da transferência nesse estágio é o fato de que devemos permitir que o passado do paciente torne-se presente. [...] Enquanto na neurose de transferência o passado vem ao consultório, neste tipo de trabalho é mais correto dizermos que o presente retorna ao passado, e é o passado" (Winnicott, 1956b/2000, p. 396). Assim, o analista se depara com os processos primários do paciente no ambiente original, não há mistura de tempos cronológicos, o passado está presente, razão pela qual a interpretação conserva pouca eficácia. De acordo com Naffah Neto, "Necessária aí é tão somente a sustentação da transferência, para que o paciente possa reviver a situação traumatogênica diante de um ambiente mais acolhedor e assim retomar experiências que, na história real, não puderam se realizar ou ficaram truncadas" (Naffah Neto, 2010, p. 88). Até mesmo os aspectos físicos do setting são incluídos nesta dinâmica transferencial, juntamente com o analista, como fica claro a partir da fala de Little a respeito de seu estado regressivo na análise com Winnicott: 
Para mim, D.W. não representava a minha mãe. Em minha ilusão de transferência, ele realmente era a minha mãe [...]. Como na verdade há continuidade entre mãe e feto, genética e física (via membranas e placentas), para mim as mãos dele eram o cordão umbilical, seu divã a placenta e o cobertor as membranas, tudo muito abaixo de qualquer nível consciente até um estágio muito posterior. (Little, 1990/1992, pp. 95-96)

Esta ideia me recorda uma situação vivida na análise de um paciente. Thiago era um corretor de seguros, que seguiu a profissão dos homens da família pai, irmãos e tios. Embora não tivesse alcançado grande sucesso profissional até seus 40 anos - ganhava o bastante para ter uma vida minimamente confortável era relativamente bem-sucedido em uma atividade paralela: por hobby, era lutador de MMA (mixed martial arts, ou artes marciais mistas), tendo saído vitorioso de alguns torneios amadores, tanto no Brasil como no exterior. Muito preocupado com seu corpo, a rigidez de seu tônus muscular refletia a de sua personalidade. Tinha pais muito conservadores, e ficou muito impressionado ao ver, ainda criança, a reação de seus pais quando seu irmão mais velho (então adolescente) engravidou acidentalmente uma namorada. Teve, ao longo da vida, grande dificuldade para manter relacionamentos amorosos, permanecendo solteiro até então, fato que relatava com grande incômodo.

Thiago demonstrava grande dependência em relação aos pais, que começavam a transparecer os sinais da idade. Embora já tivesse se mudado para sua própria residência havia quase uma década, ainda passava eventualmente alguns dias na casa da família, principalmente quando atravessava algum momento mais delicado em sua vida ou quando os pais precisavam dele. Relatava, por diversas vezes, um sentimento de indefinição em sua vida quando os pais se fossem, expressando uma profunda desesperança em si.

A preocupação de Thiago a respeito dos pais assumia, por vezes, níveis que geravam uma profunda e quase insuportável angústia. Embora, em geral a análise fosse conduzida com sessões semanais, certos momentos exigiam que aumentássemos a recorrência para até três sessões por semana - sempre durante um período pré-determinado acordado entre nós. Nessas fases, Thiago atravessava períodos de regressão profunda a um nível de intensa dependência, durante os quais seria impossível o tradicional atendimento semanal (embora, em outros momentos, ele corresse muito bem dessa forma). Da mesma forma, pouco trabalho 
interpretativo era possível nessas situações, mantendo a análise a um nível de manejo.

A psicose de transferência descrita por Little no trecho anterior me pareceu muito clara, no caso de Thiago, em uma dessas fases regressivas, quando sua mãe ficou gravemente doente. Chamou-me muito a atenção a forma com que o paciente me relatava a condição da mãe, que fora internada com uma infecção - em certo momento começou a chorar de forma incontrolável, não como uma criança, mas como criança, ao contemplar a possibilidade de sua mãe não resistir à enfermidade. Sua voz foi se tornando mais aguda e parecia que seu próprio corpo, tão hipertrofiado, diminuía de tamanho, enquanto aninhava-se entre as almofadas do divã. Decerto, para além da sobrevivência real de sua mãe, estava em jogo a minha sobrevivência como seu analista, o que envolvia minha capacidade de estar junto com ele, sobrevivendo a essa angústia durante as três sessões semanais. Chama a atenção também o uso que Thiago fez do espaço físico do consultório, buscando segurança nas almofadas como quem tentasse voltar ao útero - por vezes, em outros momentos, diria que preferia não ter nascido, queria ter ficado no útero da mãe. Em sua psicose de transferência, Thiago estava alucinatoriamente experienciando a situação passada em que viveu o abandono por parte de sua emocionalmente distante mãe. Eventualmente, enquanto a mãe se recuperava (e eu, concomitantemente, sobrevivia), Thiago foi capaz de emergir dessa fase encontrando a força emocional que ironicamente lhe faltava - pôde, posteriormente, investir em sua profissão e entrou em um relacionamento amoroso, que, embora tenha terminado em certo momento, lhe foi bastante proveitoso.

Existe, no caso de Thiago, mais um aspecto da psicose de transferência. Zimerman (2004) a classifica como um estado transferencial de tamanha distorção da realidade, que pode ser alcançado por paciente não psicóticos, que dá a impressão de uma situação psicótica. No entanto, essa situação psicótica estaria restrita à situação analítica, retomando o paciente sua vida normal terminada a sessão. Da mesma maneira que Little é descrita como alguém perfeitamente funcional no cotidiano - passou pela escola sem problemas, foi uma psicanalista e médica bem-sucedida, não se ausentando de seu trabalho, exceto apenas em 
algumas ocasiões de depressão profunda, Thiago também fazia uso de seu falso self bem adaptado, sendo-lhe possível continuar com seu dia a dia em paralelo à análise.

Percebemos, assim, que a psicose de transferência exige do analista uma atitude diferente daquela evocada pela neurose de transferência - somos alçados a "um estado de total identificação ao paciente, chegando mesmo à fusão, sem que perca, ao mesmo tempo, a orientação para a realidade externa e o contato consigo próprio" (Naffah Neto, 2010, p. 89). Nessas situações a técnica deve manter-se principalmente no suporte da relação, uma vez que a interpretação, bem como as palavras em si, conserva pouco de suas qualidades.

\subsection{As interpretações no contexto da regressão a estados primitivos}

Dias (2008) nos recorda que a interpretação, embora apropriada como importante ferramenta pela psicanálise, perpassa diferentes domínios do saber, como as variadas formas de arte. No entanto, o grande objetivo da interpretação, em geral, é a revelação de um sentido latente ou oculto em determinada situação. No contexto analítico, segundo Dias, “o que se espera do tratamento analítico é que a interpretação feita pelo analista do sentido latente dos conflitos, atualizado na relação transferencial, muitas vezes na forma da resistência, acabe por desmanchar as soluções de compromisso que constituem os distúrbios psíquicos" (Dias, 2008, p. 589)

Os pré-requisitos exigidos para que a interpretação seja possível, de acordo com a mesma autora, são a existência de um inconsciente reprimido, de conflitos inconscientes e do desejo recalcado. Trata-se, portanto, de um indivíduo já estabelecido como pessoa total, algo que, para Winnicott, não deve ser presumido no início da vida psíquica.

Ao considerarmos as noções de Winnicott e Balint sobre o uso das interpretações com pacientes regredidos a esse nível, devemos recordar a proposta de Ferenczi a respeito da confusão de línguas, segundo a qual o mundo infantil, baseado na linguagem da ternura, entra em choque com o mundo adulto, centrado na linguagem da paixão. Conforme discutido no primeiro capítulo desta tese, a linguagem da ternura se configura de forma não verbal, anteriormente à 
possibilidade de representações. O mesmo pode ser percebido nos estados de dependência absoluta, de Winnicott, e do amor primário, de Balint. $\mathrm{O}$ fato de a linguagem verbal não ser ainda uma possibilidade para esses sujeitos no momento do trauma primitivo gera um grande problema para a atividade interpretativa com esses pacientes.

Naffah Neto (2010) considera a interpretação como um processo intelectual do analista, destinado, por meio da linguagem verbal, a mobilizar processos intelectuais no paciente. $\mathrm{O}$ trabalho interpretativo alcança resultados significativos quando se estabelece uma neurose de transferência, situação em que o analista é percebido pelo paciente como um elemento distinto, uma pessoal total. Ao descrever o paciente regredido ao âmbito edipiano, Balint (1969) salienta que, a esse nível, a técnica clássica baseada nas interpretações é bastante eficaz. No entanto, só se deveria recorrer a ela no momento em que o paciente emergisse de um estado regressivo (Peixoto Júnior, 2013). Igualmente, Winnicott destaca ao longo da sua obra o valor da técnica clássica com pacientes razoavelmente maduros, assim como a importância de que o analista estabeleça uma profunda familiarização com essa técnica.

Mesmo quando adequadas, Winnicott ressalta que as interpretações devem ser utilizadas de forma simples e parcimoniosa. O autor declara (1962b/1983) que realiza interpretações por duas razões. Primeiramente, caso não faça nenhuma, o paciente fica com a impressão de que o analista tudo sabe a seu respeito e compreende tudo que é dito. A segunda questão é a mobilização dos processos intelectuais, o que representa um problema quando estes se encontram dissociados do indivíduo, como nos casos de regressão à dependência absoluta.

Quanto ao primeiro caso, o propósito da interpretação na neurose de transferência corresponde a proporcionar ao paciente a retenção de alguma qualidade do analista como objeto externo, embora o terapeuta ainda se mantenha paradoxalmente dentro do campo subjetivo do paciente: "Nesta posição eu tenho algumas características de um fenômeno de transição, uma vez que, embora eu represente o princípio da realidade, e seja eu quem mantém um olho no relógio, nem por isso deixo de ser um objeto subjetivo para o paciente" (Winnicott, 1962b/1983, pp. 152-153). Em um trabalho posterior, Winnicott afirma: “Ao 
interpretar, acredito que o faço principalmente no intuito de deixar o paciente compreender os limites da minha compreensão" (Winnicott, 1969/1975, p. 122). Nesse caso, o analista se apresenta como um objeto externo, que não é fruto da onipotência narcísica do paciente ao destacar-se como real através das falhas - o analista só poderia ser infalível se fosse exclusivamente parte do sujeito, ou seja, um objeto subjetivamente concebido. Paralelamente, Balint também chama a atenção a esse risco: "Quanto mais a técnica e o comportamento do analista sugiram onisciência e onipotência, maior é o risco de uma forma maligna de regressão" (Balint, 1969, p. 173).

No segundo ponto, Winnicott nos expressa sua preocupação quanto ao potencial defensivo contido na intelectualização do material interpretado, já que as interpretações envolvem uma representação verbal de conteúdos emocionais. Essas defesas seriam evitadas com a simplicidade das interpretações, de forma que não se exija tanto dos processos do pensamento. Nos diz Winnicott:

Minhas interpretações são econômicas, pelo menos assim espero. Uma
interpretação por sessão me satisfaz, se está relacionada com o material produzido
pela cooperação inconsciente do paciente. Digo uma coisa, ou digo uma coisa em
duas ou três partes. Nunca uso frases longas, a menos que esteja muito cansado.
Se estou próximo da exaustão, me ponho a ensinar. Além disso, na minha opinião,
uma interpretação que contém a expressão 'além disso' é uma sessão de ensino.
(Winnicott, 1962b/1983, p. 153)
O fragmento acima evoca ainda outra importante consideração de Winnicott, a respeito da necessidade pessoal do analista em produzir interpretações, ignorando a temporalidade do sujeito em análise. O autor declara (1969/1975) que é muito mais valioso para o paciente que o analista espere e permita que ele alcance certos insights por si mesmo, de forma criativa, ao invés de fazê-lo pela produção de interpretações (o que deve ser diferenciado das intepretações em si). Isto se mostra especialmente claro quando o paciente demonstra estar seguindo um certo caminho em suas associações e nos sentimos compelidos a mostrar-lhe imediatamente seu destino através de uma interpretação. No entanto, se permitimos que ele continue por si mesmo, havendo já alguma sintonia de sua parte para com o analista, existe uma grande chance de que ele descubra justamente aquilo que a interpretação pretendia elucidar, mas de uma forma mais genuína e proveitosa. O que o paciente sente neste momento não se resume à satisfação por ter alcançado certo insight, mas também está ligado ao fato de o analista ter respeitado sua 
singularidade ao não interrompê-lo. Devemos, no entanto, destacar que o material interpretativo deve ser utilizado, mas não de acordo com as necessidades pessoais do analista, e sim do paciente. A interpretação assume aqui, portanto, uma face de adaptação do ambiente/analista às necessidades do paciente.

O autor ainda acrescentaria: "Esse trabalho [interpretativo] por parte do analista, para surtir efeito, precisa relacionar-se à capacidade do paciente de colocar o analista fora da área dos fenômenos subjetivos" (Winnicott, 1969/1975, p. 122), o que se mostra muito difícil no contexto da psicose de transferência. Trata-se da capacidade do paciente de usar o analista como objeto externo, algo somente possível quando o primeiro é capaz de experienciar sua destrutividade máxima mediante a sobrevivência e não retaliação do segundo.

Nesse ponto de desenvolvimento que examinamos aqui o sujeito está criando o objeto no sentido de descobrir a própria externalidade, e há que acrescentar que essa experiência depende da capacidade do objeto de sobreviver. [...] Se for numa análise que isso esteja se realizando, então, o analista, a técnica analítica e o cenário analítico, todos entram como sobrevivendo ou não aos ataques destrutivos do paciente. Essa atividade destrutiva constitui a tentativa, empreendida pelo paciente, de colocar o analista fora da área do controle onipotente, isto é, para fora, no mundo. Sem a experiência da destrutividade máxima (objeto não protegido), o sujeito jamais coloca o analista para fora e, portanto, não pode mais do que experimentar uma espécie de auto-análise, usando o analista como projeção de uma parte do eu (self). (Winnicott, 1969/1975, p. 127)

Nesse contexto, o papel do analista é o de apenas sobreviver e não retaliar, sustentando a confiabilidade do ambiente. A necessidade pessoal de produção de interpretações por parte do analista, poderia ser vivenciada pelo paciente como uma intrusão ou retaliação, uma ruptura da continuidade do ser, algo especialmente doloroso considerando que o analista ainda não se tornou parte do mundo externo.

Como Dias nos afirma enfaticamente:

Uma interpretação, na linha tradicional, é não apenas desnecessária, como prejudicial e desaconselhável, sendo prematura e invasiva, em não poucos sentidos: primeiro, porque ao referir-se, pela interpretação, àquilo que o paciente, em seu amadurecimento, ainda não chegou - conflitos inconscientes, voracidade, ambivalência, ameaça de castração etc. -,$o$ analista não só mostra desconhecer a problemática real do paciente como extrapola a capacidade maturacional deste, repetindo, provavelmente, o trauma original (Dias, 2008, p. 595)

Isso nos remete novamente às ideias de Ferenczi, principalmente no que se refere ao seu receio quanto à possibilidade da repetição do evento traumático na 
situação analítica. $\mathrm{O}$ autor húngaro foi pioneiro no questionamento sobre o uso das interpretações, especialmente ao criticar a suposta infalibilidade delas. Ferenczi realizaria ainda uma crítica à compulsiva fabricação de interpretações por parte do analista, tal qual Winnicott faria anos mais tarde:

Ser parcimonioso nas interpretações, em geral, nada dizer de supérfluo, é uma das regras mais importantes da análise; o fanatismo da interpretação faz parte das doenças de infância do analista. Quando se resolve as resistências do paciente pela análise, chega-se algumas vezes, na análise, a estágios em que o paciente realiza todo o trabalho de intepretação quase sozinho, ou apenas com uma ajuda mínima. (Ferenczi, 1928/2011, p. 38)

Percebemos, portanto, o quão perniciosa pode ser a interpretação em certos casos, na ótica ferencziana. Retomando a ideia de confusão de línguas, é possível conceber a interpretação, no contexto regressivo, como uma invasão passional do adulto (analista) à linguagem da ternura da criança no paciente - com palavras carregadas de um significado que lhe é, no fundo, totalmente alheio. Lejarraga (2008) salienta que, segundo a ótica ferencziana, as interpretações clássicas perdem seu efeito porque o paciente se apresenta como uma criança imune ao raciocínio e sensível apenas à benevolência sincera da parte do analista, este "[...] munido de infinita paciência, tato e compreensão [...]" (Lejarraga, 2008, p. 124). Dessa forma, Ferenczi parece constituir uma importante fundamentação tanto da clínica winnicottiana, quanto, de maneira mais explícita, da balintiana.

Balint segue ideias muito próximas às de Winnicott ao problematizar o uso das interpretações no ambiente clínico. Retomando sua divisão, exposta no segundo capítulo desta tese, a respeito das três áreas da mente - a da criação, a da falha básica e a edipiana -, o autor sugere que a interpretação só pode conservar seu valor quando utilizada diante de pacientes regredidos à mais avançada das três áreas, a relativa ao complexo de Édipo. Mas não costuma ser assim nos casos de regressão aos momentos mais primitivos:

Em níveis edipianos - ou mesmo em alguns daqueles comumente chamados 'préedipianos' - uma interpretação adequada, que torna consciente um conflito reprimido, resolvendo uma resistência ou desfazendo uma cisão, é capaz de pôr em movimento novamente as livres associações do paciente; no nível da falha básica isso não ocorre necessariamente. A interpretação é experienciada como interferência, crueldade, demanda não garantida ou intrusão injusta, como ato hostil ou sinal de afeto, ou é sentida tão sem vida, de fato morta, que não tem qualquer efeito. (Balint, 1969, p. 175) 
Nesses casos, as palavras perdem seu significado compartilhado, sendo vivenciadas pelo paciente de uma forma totalmente imprevisível em relação ao que o analista pretendia. Segundo Balint, este é um problema agravado pelo tipo de analista afeito a interpretar tudo o que acontece na situação analítica em termos de transferência. Dessa maneira o analista se oferece às tendências ocnofílicas do paciente como um objeto a ser agarrado, ao mesmo tempo em que interpreta tudo o que contraria essa tendência como resistência ou agressividade, por exemplo, criando uma atmosfera ambivalente - enquanto anseia por independência, o paciente vê esse caminho travado por interpretações de cunho ocnofílico por parte do analista. Mesmo assim, Balint ressalta que o trabalho do analista ainda se baseia nas palavras do paciente, embora a comunicação com o paciente regredido ao nível da falha básica - ou mesmo da criação - assuma uma forma diferente:

A orientação técnica padrão é correta nesse caso também, a tarefa do analista é entender o que há por trás das palavras do paciente; o problema é apenas como comunicar esse entendimento ao paciente. Minha resposta é aceitar sem reservas o fato de que as palavras se tornaram inconfiáveis e desistir, por hora, de qualquer tentativa de forçar o paciente de volta ao nível verbal. Isso significa abandonar qualquer tentativa de 'organizar' o material produzido pelo paciente - não é o material 'certo', de qualquer forma - e tolerar isso de forma de que esse material permanece incoerente, sem sentido, desorganizado, até que o paciente - após retornar ao nível edipiano da linguagem convencional - seja capaz de dar ao analista a chave para entendê-lo. (Balint, 1969, p. 177, grifo meu)

Posso ilustrar rapidamente essa afirmativa através de uma outra situação que aconteceu em minha prática. Um paciente, que logo depois do ocorrido se mostraria em uma significativa fase regressiva, me relatou um sonho no qual se encontrava com seu supervisor (alguém que não reconhecia seu valor) no próprio ambiente de trabalho e o estrangulava impiedosamente. É importante participar o contexto no qual sua análise se encontrava nesse momento, em que, após alguns meses de certa calmaria, surgiam muitas manifestações agressivas direcionadas a mim devido à minha incompreensão do que ele realmente queria dizer, segundo ele, que se expressava sempre de forma confusa e enigmática. Prontamente, ofereci-lhe uma interpretação em um sentido de que eu estaria personificado em seu sonho na figura de seu supervisor - afinal, eu o estaria observando, de certa forma. Quanto a seu ato no sonho, ele estaria, na verdade, me enforcando com toda sua violência porque eu não estava sendo capaz de reconhecer suas necessidades, assim como o supervisor não reconhecia sua produção. Embora a interpretação do conteúdo se 
provasse eventualmente correta algum tempo depois, minha atitude ao interpretar então foi errônea. A partir daí surgiu uma grande ansiedade, só elaborada posteriormente (após o reconhecimento de meu erro) como uma angústia persecutória tanto por minha onipresença - estava presente até mesmo em seus sonhos! - quanto a de sua mãe durante a infância. Naquele momento, entretanto, essa ansiedade não teve qualquer possibilidade de representação, sendo vivida sem que fosse possível descrevê-la (embora seja possível identificar que surgiram ansiedades depressivas com as quais o paciente era ainda incapaz de lidar). Decerto, meu equívoco teve algum efeito positivo para a análise do paciente - a partir dele, junto com outros sinais, pude reconhecer sua atitude regressiva e ele pôde experienciar e elaborar o trauma gerado por sua mãe sufocadora. No entanto, minha tarefa naquele contexto não era, como nos diz Balint no fragmento anterior, organizar esse conteúdo vivido no sonho. De acordo com as ideias do autor, diante dessa situação, o analista deve permanecer disponível, vivo, na qualidade de uma substância ou objeto primário - como um analista não intrusivo (unobtrusive).

Balint sugere então que a sustentação desse estado desorganizado do material, dessa relação não verbal, significa aceitar a regressão e a atuação (acting $o u t$ ) como uma forma legítima de comunicação - trata-se de criar um ambiente que torne possível ao paciente tolerar o estado regressivo em uma experiência mútua, sem a interferência de pressões externas. Winnicott sugere uma visão similar a respeito do manejo como técnica ao lidar com pacientes regredidos, em substituição (e complemento) às atividades interpretativas. Veremos a seguir, portanto, a proposta desses autores a respeito da forma com que se constituem os estados regressivos, suas características e da postura esperada do analista diante desse tipo de paciente.

\subsection{A regressão na situação psicanalítica}

A postura da parte do terapeuta adquire uma importância especial diante de um determinado grupo de indivíduos, correspondente àqueles que ainda não estão integrados, cujas questões remetem ao desenvolvimento emocional primitivo - aqueles pertencentes, portanto, ao terceiro grupo descrito por Winnicott em Aspectos clínicos e metapsicológicos da regressão. Para estes, a regressão assume 
um papel fundamental, como uma nova chance para que o desenvolvimento possa ser retomado.

É importante destacar que tal desenvolvimento, segundo a teoria de Winnicott, é algo natural, uma tendência que faz parte da natureza humana - o que existe é uma continuidade de ser. Contudo, embora o autor (1954/2000) deixe claro que o progresso não pode ser revertido, ele pode ser extremamente dificultado e até paralisado. Devemos, neste momento, recordar resumidamente algumas das ideias winnicottianas exploradas até aqui.

Faz parte do papel do ambiente adaptar-se ativamente às necessidades do bebê, de forma que o self seja preservado e o desenvolvimento não seja perturbado. Para isso, o ambiente precisa ser suficientemente bom - isto é, deve atender ao que o bebê precisa, mas as falhas constituem uma parte importante do processo. Contudo, quando as falhas tornam-se por demais frequentes ou intensas, são percebidas como intrusões pelo jovem ego do bebê. Tais intrusões suscitam reações, que podem fazer com que a criança se adapte ao ambiente, e não o contrário. Da mesma forma, a necessidade pessoal de produção de interpretações por parte do analista, discutida anteriormente, poderia fazer com que o paciente se adaptasse ao analista ao invés do contrário, apresentando o material esperado pelo segundo e não aquele que lhe é próprio. Quando isso ocorre com frequência na situação original, a reação à intrusão promove uma ruptura na continuidade do ser, ocasionando o surgimento de uma nova porção do indivíduo, cujas ações baseiam-se unicamente em reagir às intrusões do ambiente em defesa da parte original da personalidade. A mesma reação pode ser evocada por interpretações intrusivas ou uma falha no manejo. Esta porção é chamada de falso self, e se desenvolve com a função de preservar o verdadeiro self da destruição frente a um ambiente não suficientemente bom.

No desenvolvimento inicial do ser humano o ambiente que age de modo suficientemente bom permite que o crescimento pessoal tenha lugar. Os processos do eu podem nesse caso permanecer ativos, numa linha ininterrupta de crescimento vivo. Se o ambiente não se comporta de modo suficientemente bom, o indivíduo passa a reagir à intrusão, e os processos do eu são interrompidos. Se este estado de coisas atinge um certo limite quantitativo, o núcleo do eu passa a ser protegido. Há uma paralisação, e o eu não consegue novos progressos a não ser que a situação da falha ambiental seja corrigida [...]. Com o eu verdadeiro protegido, surge um eu falso construído sobre a base de uma submissão defensiva, 
a aceitação da reação à intrusão. $\mathrm{O}$ desenvolvimento do falso eu é uma das organizações defensivas mais bem-sucedidas, destinada a proteger o núcleo do eu verdadeiro, e sua existência tem por consequência a sensação de inutilidade. (Winnicott, 1954/2000, p. 389).

O falso self continua relacionando-se com o mundo externo de forma automática e superficial, enquanto o verdadeiro self permanece oculto, como se estivesse guardado em uma câmara frigorífica à espera de uma nova oportunidade para retomar seu desenvolvimento, em um ambiente mais propício.

Para Winnicott, na experiência clínica essa nova chance deve ser proporcionada pelo analista, ao permitir a regressão, um retorno a momentos muito primitivos do desenvolvimento emocional em que o mundo se baseia na relação entre o bebê e a mãe. Masud Khan (1960/1977), talvez o mais obstinado (e controverso) seguidor de Winnicott, relata o caso de uma paciente que atendeu durante aproximadamente três anos e que passou por um momento de regressão bastante marcante. A paciente, Sra. X, que beirava os quarenta anos na ocasião da análise, havia precisado fugir de seu país rumo à Inglaterra por causa da Segunda Guerra Mundial, onde se casou e teve um filho. Entretanto, descobriu rapidamente que o marido era alcoólatra e extremamente irresponsável. Após um episódio em que quase entrou em um colapso nervoso, a Sra. $X$ foi levada a um psiquiatra, que encaminhou o caso para Khan. Este identificou, ao longo do tratamento, três fases distintas.

Durante a primeira, que durou pouco mais de um ano, após um período em que o material interpretativo era abundante, a Sra. $X$ retraiu-se tanto de seu meio social como do analista, repelindo qualquer interpretação transferencial. No caso, ao contrário do que se poderia pensar, a aliança terapêutica não estava perdida. $\mathrm{Na}$ realidade, a imensa esperança que depositava na análise exagerou a intensidade afetiva da relação terapêutica, indicando uma regressão à dependência absoluta.

A segunda fase se iniciou após um período de férias, em que ocorreu "uma regressão gradual e controlada ao que a paciente descreveu como 'um estado de não ser nada', e a saída desse estado" (Khan, 1960/1977, p. 184). Nesse momento, a Sra. X recordou-se de experiências infantis envolvendo principalmente o pai e uma babá, antes idealizados; agora a paciente percebia uma nova face de tais figuras: "O pai, na verdade, fora um inútil; a babá também. Foram bondosos e ineficazes. [...] 
O pai fora também um covarde, que tendia a lidar com as situações através da fuga, como quando engravidara uma governanta e ficara abjetamente impotente" (Khan, 1960/1977, p. 185). Nessa fase, o estado maníaco não se reproduziu. O que se estabeleceu foi uma tristeza profunda, que transmutou-se em um estado de não ser nada. Os planos de manter-se sozinha, sem a ajuda do problemático marido, foram abandonados. Para o autor, "este foi o clímax da segunda fase, e o que, neste relato, chamo de regressão. Durou perto de três meses. Se bem que o trabalho para conseguir essa experiência regressiva tivesse sido gradual e controlado, seu surgimento decisivo foi súbito e absoluto" (Khan, 1960/1977, p. 190). Essa regressão foi observada pelo autor (1960/1977) a partir de quatro aspectos: (1) paciente com total sensação de perda (principalmente em relação ao filho e ao casamento); (2) uma dependência quase absoluta do analista; (3) reações às invasões; (4) experiência de dor, às vezes física, em outros momentos psíquica.

Durante a terceira e última fase, Khan percebeu que a Sra. X caíra em um estado claramente paranoide, em que acreditava que o analista, o psiquiatra que a indicou e o marido formaram um conluio contra ela, que nunca teria tido chances de recuperar-se. Nesse momento, o material interpretativo ressurgiu com maior frequência, bem como a disposição da paciente em introjetar as interpretações do analista.

Assim, ao relatar o caso da Sra. X, Masud Khan mostra clinicamente como a técnica deve se adaptar a esse tipo de situação, em que a paciente, de acordo com suas próprias palavras, voltou a um estado de não ser nada, de quase absoluta dependência em relação ao analista. Sobre a atitude do analista frente ao paciente regredido, Khan formula um ponto de vista deveras similar àquele de Balint, conforme exposto anteriormente:

Meu papel na situação analítica era, fundamental e dinamicamente, este: estar ali, vivo, atento, corporificado e vital, mas não invadi-la com qualquer necessidade pessoal de produzir suas experiências efetivas para seus correlatos mentais. Fiz ainda muitos experimentos com modos de ficar em silêncio com ela. Se eu não estivesse totalmente presente com toda a minha atenção corporal, ela imediatamente o sentiria. Nunca pude descobrir como ela o sentia, mas sempre percebia que isto havia acontecido pela mudança de ritmo afetivo ou por alguma nova linha de material surgida no dia seguinte. (Khan, 1960/1977, p. 193). 
Celia e Norberto Bleichmar reforçam essa ideia de Masud Khan, ao citar alguns dos fatores envolvidos na relação entre setting e regressão: “o analista oferece uma presença predizível, está presente, preocupa-se com o paciente, expressa seu amor e seu ódio [...], não julga moralmente o material que lhe é apresentado, nem a pessoa que o apresenta" (Bleichmar \& Bleichmar, 1989/1992, p. 236). Winnicott (1954/2000) também ressalta que a possibilidade de regressão resulta da confiabilidade do contexto analítico. Embora o material interpretativo não deixe de fazer parte da análise, é o cuidado ambiental, o manejo, o que corresponde a uma reedição da maternagem proporcionada pelo analista, agora em um novo contexto - o setting psicanalítico - que assume o protagonismo técnico na prática clínica. Trata-se de oferecer um ambiente propício que permita o resgate do momento em que a continuidade do ser foi interrompida. Segundo Winnicott (1954/2000), quando ocorre esse tipo de falha intolerável que provoca a reação às invasões do ambiente, há um congelamento da situação. $\mathrm{O}$ paciente que precisa passar por um estado regressivo para resolver uma questão tão importante (como foi o caso da Sra. X relatado por Masud Khan) tem uma espécie de predisposição à regressão no setting analítico. De acordo com Winnicott, "é como se houvesse uma expectativa de que surjam condições novas, justificando a regressão e oferecendo uma nova chance para que o desenvolvimento ocorra, esse mesmo desenvolvimento que havia sido inviabilizado ou dificultado inicialmente pela falha do ambiente" (Winnicott, 1954/2000, p. 378).

Dois casos, ambos atendidos por Winnicott, nos chamam ainda a atenção quanto à regressão como oportunidade terapêutica no atendimento a pacientes borderlines - aqueles referentes à análise de Margaret Little e à de Harry Guntrip, os dois já mencionados algumas vezes ao longo desta tese. Encontramos uma grande riqueza nesses dois casos principalmente porque, além dos eventuais comentários de Winnicott ao longo de sua obra, ambos eram psicanalistas e relataram seus casos a partir de suas próprias perspectivas.

Little foi uma eminente psicanalista da Sociedade Britânica de Psicanálise, tendo desenvolvido importantes trabalhos a respeito da contratransferência e da psicose de transferência. Antes de ter seus primeiros contatos com a psicanálise, na qualidade de paciente, Little já era uma importante médica, diretora de uma clínica 
geral. Após conviver com o esgotamento nervoso de uma amiga com a qual morava, guarnecida de tendências suicidas, ao mesmo tempo em que estava bastante ocupada com a direção da clínica, Little decidiu buscar análise pela primeira vez, já aos trinta e cinco anos. Em seu livro Ansiedades psicóticas e prevenção, de 1990, Little descreve o longo caminho que percorreu como analisanda ao longo de suas experiências com três analistas, à procura de soluções para seus sofrimentos primitivos e sua personalidade borderline, de acordo com ela própria (Little, 1990/1992).

O primeiro dos três, chamado de Dr. X, era um analista de orientação junguiana, e pouco foi capaz de contribuir para o quadro de Little. Seu falso self bem adaptado, singularizado pela hipertrofia das funções intelectuais, camuflava suas características psicóticas a analistas mais incautos, como nosso Dr. X, que enxergava sua paciente como uma neurótica. No entanto, Little relata que, ao menos, seu primeiro analista a ajudou a se libertar de sua amiga dominadora, quando lhe mostrou que esta colega teria direito a se matar, se assim o desejasse, e que ela nada poderia fazer a respeito. Após cerca de dois anos de análise, o Dr. X encerrou o tratamento gradualmente, dizendo-lhe que ela não precisava mais de análise, mas de síntese, o que poderia fazer sozinha.

O Dr. X apresentou Little a Ella Freeman Sharpe, outra importante psicanalista inglesa, em 1938. Little foi visitá-la em sua casa e teve uma alucinação, na qual via Sharpe envolta em uma névoa, como uma aranha, na teia formada pelos seus cabelos. Contou que o Dr. X disse-lhe que não precisava mais de análise e saiu correndo da casa dela em pânico. Little voltaria a procurar Sharpe dois anos depois, quando se envolveu emocionalmente com um paciente. Daí se seguiria então um período de sete anos de análise.

Uma situação ocorrida na primeira sessão viria a definir toda a sua análise com Sharpe. Little estava deitada no divã, paralisada, enquanto Sharpe permanecia igualmente calada. Little começou então a gritar que aquilo não poderia ser real, lembrando-se de sua visão alucinatória anterior (Sharpe em meio à névoa), como se estivesse tendo um pesadelo. Ao final da sessão, Sharpe a convidou a se sentar para conversar e interpretou seu medo como ansiedade de castração. No entanto, segundo nos conta Little, tratava-se de uma ansiedade relativa a um nível muito 
mais primitivo: “O meu medo - 'um pavor que só as crianças podem sentir' [...] era de uma total destruição, de ser fisicamente mutilada, ficar irremediavelmente louca, ser morta, abandonada e esquecida por todo o mundo como alguém que nunca existira [...]" (Little, 1990/1992, p. 34). Esse medo não era, portanto, parte de uma neurose de transferência, mas sim de uma psicose de transferência, como Little perceberia alguns anos depois. A análise com Sharpe permaneceu nesse embate; de um lado, Little falando sobre angústias precoces, de outro, Sharpe interpretando um contexto edípico. O resultado que se desenvolveu a partir desse ambiente foi que Little acabou por assumir uma postura de submissão em relação a Sharpe, uma reprodução da relação que tinha com sua mãe, como nos lembra Naffah Neto: "Sharpe [...] - gentil, cálida, generosa, e absolutamente incapaz de perceber as necessidades primárias de Little -, encarnava, sem se dar conta, as próprias características da mãe da paciente. Little tornou-se, então, dependente e submissa a ela, como era, originalmente da mãe" (Naffah Neto, 2008, p. 109). Essa submissão a levaria, como paciente de Sharpe, a tornar-se ela mesma analista.

Em abril de 1947, pouco mais de um ano após a morte do pai de Little, Sharpe sugeriu que a análise fosse terminada depois do verão, mas no mês seguinte acabou por falecer de um ataque cardíaco - Little, clínica hábil, já havia notado os sinais de uma doença cardíaca em Sharpe e tinha comentado a esse respeito com ela anteriormente. A perda abalou Little profundamente em diversos níveis:

\begin{abstract}
Então, lá estava uma repetição do trauma anterior da morte do meu pai, que nunca fora superado, a realidade tendo sido quase negada na época; e aquilo repetira um trauma ainda mais antigo, quando de modo parecido a Srta. Sharpe evitara que eu chorasse a perda de uma tia querida e, em vez disso, me fornecera uma interpretação de transferência sobre as suas próximas férias, que me pareceu tão ilógica quanto a maioria das 'explicações' da minha mãe. (Little, 1990/1992, pp. 38-39)
\end{abstract}

Little procuraria então Sylvia Payne, tendo com ela uma sessão na qual chorou sem parar. Ao final Payne disse-lhe, surpresa, que Little estava muito doente. Ela lhe retrucou que era justamente o que estava tentando dizer a Sharpe por todos esses anos. Na relação com Sharpe, Little considera que não houve empatia, mas uma confusão de línguas, sugerindo uma referência a Ferenczi - o que é destacado pela submissão de Little a Sharpe, que ocupara a posição de "adulto agressor" ao desmentir o sofrimento de Little, tal qual Ferenczi preconizara ao discutir a hipocrisia profissional. Payne a encaminharia então a Marion Milner, que 
ajudou Little durante um ano, até que esta conhecesse Winnicott, em 1949, aos quarenta e oito anos.

Na primeira sessão com Winnicott, Little repetiu a condição de paralisia, sem nada falar. Ao final, Winnicott, que também teria permanecido em silêncio, the disse: "Eu não sei, mas tenho a impressão de que, por alguma razão, você está me excluindo" (Little, 1990/1992, p. 44). A paciente relatou ter sentido um grande alívio ao perceber que Winnicott se permitia não saber de tudo, o que significaria não se forçar a interpretar tudo. Logo no início da análise de Little com Winnicott, uma icônica situação ocorreu, como ela relata:

Em uma das primeiras sessões com D.W., me senti totalmente desesperançada de fazê-lo um dia entender qualquer coisa. Eu caminhei ao redor da sua sala, tentando encontrar um caminho. Pensei em me atirar pela janela, mas achei que ele me impediria. Depois, pensei em jogar fora todos os seus livros, mas finalmente investi contra um grande vaso cheio de lilases brancos, quebrando-o e pisando nele. D.W. precipitou-se para fora da sala, mas voltou um momento antes do final do horário. Ao me encontrar limpando a sujeira ele disse: 'Eu poderia ter esperado que você fizesse isso (limpar, ou sujar?), mas mais tarde.' No dia seguinte, uma réplica exata havia substituído o vaso e os lilases. Alguns dias depois, ele explicou que eu havia destruído uma coisa de que ele gostava. (Little, 1990/1992, p. 45)

Quando Winnicott diz que esperava que isso acontecesse mais tarde, queria dizer que esperava uma atitude agressiva seguida de uma ação reconciliatória (do estágio do concernimento), mas não quando estava imersa em um momento tão primitivo. Naffah Neto (2008) sugere que neste momento Winnicott teve a convicção de que estava diante de uma paciente borderline. Este autor comenta ainda o risco da saída de cena de Winnicott, durante a qual o desejo suicida poderia ter reaparecido. De qualquer forma:

O fato é que Winnicott voltou à sessão, não retaliou o ato destrutivo de Little e, mais do que isso, repôs na sala, nas sessões seguintes, um vaso idêntico àquele quebrado, com os mesmos lilases brancos. Como um bom ego-auxiliar, ele completou o ato reparatório que sua paciente por si só não teria condições de realizar, mas que havia iniciado quando limpara o chão dos dejetos. É como se dissesse a ela: 'Eu posso resistir intacto aos seus impulsos destrutivos e, assim, permanecer sendo seu analista. (Naffah Neto, 2008, p. 111)

Nas sessões seguintes, Little passou por acessos de pânico, durante os quais segurava as mãos de Winnicott com força até que eles passassem. Winnicott lhe diria que achava que ela estava revivendo a experiência de ter nascido, sendo o enlace das mãos como o cordão umbilical. Isso revela a forma com que Winnicott 
lidava com as diferentes dimensões do holding, em nível literal e metafórico, como Little nos explica:

Metaforicamente ele estava controlando (holding) a situação, dando apoio, mantendo contato em todos os níveis com qualquer coisa que estivesse acontecendo, dentro e ao redor do paciente e no relacionamento com ele. Literalmente, durante intermináveis horas ele segurou as minhas duas mãos apertadas entre as dele, quase como um cordão umbilical, enquanto eu ficava deitada, frequentemente escondida debaixo do cobertor, calada, inerte, retraída, apavorada, com raiva ou em lágrimas, dormindo e às vezes sonhando. (Little, 1990/1992, p. 46)

A paciente se refere então à exaustão que Winnicott deve ter experimentado nesses momentos - o que o levou às vezes a adormecer, acordando de sobressalto (o que a enfurecia) - e também à dor que deve ter sentido em suas mãos. Devemos destacar o quanto o paciente regredido exige uma presença massiva de parte do analista, o que inclui em certos casos a necessidade do contato corporal. Em A experiência mãe-bebê de mutualidade, de 1970, Winnicott relataria esse caso, dizendo que teve certa dificuldade em adaptar-se ao ritmo de Little. No entanto, considera que essa experiência foi fundamental para o desenrolar da terapia, sendo a cena de violência - a destruição do vaso - um teste para a sua capacidade de atender às necessidades de Little, bem como de comunicar-se ao nível não verbal.

Ainda em termos do manejo, por vezes Winnicott guardava as chaves do carro de Little durante as sessões, de forma a evitar que ela saísse inesperadamente e dirigisse imprudentemente pelas ruas - decerto, já temeroso quanto às tendências suicidas de sua paciente. Winnicott acreditava que a regressão deveria, tanto quanto possível, ser circunscrita no ambiente analítico, sugerindo a Little que ficasse por um tempo em uma sala separada para se recobrar, quando necessário. Ele repetiria essa atitude algum tempo depois, em um momento de grande importância relacionado a um conflito entre Little e sua mãe.

Primeiramente, devemos dizer que as descrições de Little sobre sua mãe são sempre negativas, o que fez com que Winnicott lhe dissesse: "Sua mãe é imprevisível, caótica, e estabelece o caos ao seu redor" (Little, 1990, p. 50), comentário recebido pela paciente não como uma interpretação psicanalítica, mas como uma revelação. Posteriormente, após duas interrupções na análise devido a problemas de saúde de Winnicott (acompanhadas da angústia gerada pela 
possibilidade de que ele morresse), se seguiu um período no qual Little sentia que sua análise não teria fim, atribuindo esses fracassos a Winnicott. Nesta mesma época explodiu com sua mãe devido a seus comentários sarcásticos, tornando a vêla apenas dois anos depois. Em seguida, saiu de férias para o campo, no norte da Escócia, onde recebeu uma correspondência da mãe que lhe fazia uma exigência extravagante. Sua explosão havia sido, portanto, ignorada. Little subiu por uma trilha batendo os pés no chão de raiva, até que, no dia seguinte, escorregou na grama molhada e quebrou o tornozelo. Estava próxima ao hotel, mas, caso isso tivesse ocorrido na trilha, durante o dia anterior, teria ficado presa e sozinha por um tempo indeterminado, até ser encontrada. Ao retornar, depois de algum tempo internada para se recuperar da fratura, Little passou por um período de grande confusão - não conseguia se distinguir de sua mãe e, consequentemente, era incapaz de reconhecer quem ela própria era. Winnicott sugeriu então que Little se internasse, como voluntária, em um hospital, de forma que não cometesse suicídio. Após uma negociação (que incluiu uma furiosa investida sobre Winnicott, que apenas a segurou sem a machucar), Little acabou concordando e passou algumas semanas internada. Winnicott a levou até o hospital e a manteve segura, impedindo que o então diretor substituto, adepto da eletroconvulsoterapia, usasse este tipo de técnica com ela.

O período no hospital é descrito por Little como uma época em que o isolamento the trouxe um contato com suas potencialidades criativas. Passou a escrever poemas e a pintar. No entanto, se sentia ainda deprimida - observou um pedaço de corda no jardim e considerou novamente o suicídio, embora percebesse que isso não seria uma solução e sim um ato de loucura. Após esse insight, Little diz nunca mais ter pensado em suicídio.

Quando saiu da internação, a análise com Winnicott passou a aproximarse do fim, o que foi ilustrado por uma interpretação da parte do analista (com o mesmo caráter de revelação que Little descreveu anteriormente): "Ele me disse que o medo de aniquilação que eu sentia estava relacionado com a 'aniquilação' que já ocorrera: eu havia sido aniquilada fisicamente, mas de fato sobrevivera, e estava agora revivendo emocionalmente a experiência passada" (Little, 1990/1992, p. 63). Nesse momento, a natureza das sessões já havia se alterado, e o sofrimento 
primitivo havia ficado, de certa forma, para trás. Little diz que essa superação se deu através da "brincadeira" no setting, salientando a visão de Winnicott sobre o sofrimento na situação analítica - ele acreditava no valor terapêutico de uma relação agradável. Após o término desse processo, Little voltaria ainda para uma segunda análise com Winnicott alguns anos depois, a qual durou cerca de um ano e meio, para a elaboração de conflitos edipianos. Devemos destacar, no entanto, que tais angústias já haviam aparecido anteriormente, na ocasião da separação de Winnicott de sua primeira esposa, quando Little sentiu-se muito enciumada, mas isso permaneceu como um pedaço isolado da análise que só posteriormente poderia ser elaborado. Naffah Neto nos explica: “[...] nessa primeira etapa, seu self, dado seu estado de desintegração, não tinha condições de se apropriar desse tipo de material, sob a forma de uma elaboração consistente" (Naffah Neto, 2008, p. 119).

O outro caso de regressão terapêutica que consideramos relevante mencionar aqui é o de Harry Guntrip. Ele passou por experiência semelhante à de Little em sua análise com Winnicott, tendo também nos disposto um tocante relato a respeito dela (Guntrip, 1975/2001). Além de psicanalista, Guntrip era pastor protestante, da mesma forma que o pai fora antes. Sua mãe era comumente descrita como emocionalmente distante, o que certamente influenciou sua personalidade assumidamente esquizoide, tema que lhe foi muito caro ao longo de sua obra.

Guntrip nos descreve duas experiências de análise (a partir das anotações que manteve das mais de mil sessões com Fairbairn nos anos 50 e de cento e cinquenta sessões com Winnicott nos anos 60), as tendo procurado de forma a lidar com sua esquizoidia e uma amnésia total quanto ao trauma que sofreu, aos três anos e meio, quando da morte de seu irmão mais novo. Começou sua primeira análise com Fairbairn em 1949 após ler seus trabalhos, o que, pensava Guntrip, evitaria conflitos intelectuais. Devemos dizer que dessa análise surgiu uma importante relação profissional, a partir da qual Guntrip desenvolveu e propagou os obscuros escritos de Fairbairn, principalmente a respeito da esquizoidia. Uma das principais contribuições de Guntrip - a noção de ego regredido - foi prontamente aceita por Fairbairn, que considerou que seu pupilo solucionou um problema que havia na sua teoria relativo à regressão, o que se tornaria claro, inclusive, na incapacidade de Fairbairn em lidar com a tendência regressiva de Guntrip na análise. 
Embora bastante revolucionário em sua teoria - Fairbairn propunha uma radical ruptura em relação à psicanálise clássica, especialmente quanto ao modelo pulsional freudiano - Guntrip surpreendeu-se ao encontrar um analista que se valia de uma técnica bastante conservadora, baseada em interpretações sobretudo edipianas, um "interpretador técnico" (Guntrip, 1975/2001, p. 225). É interessante mencionar, no entanto, que, embora se portasse dessa forma durante as sessões, Guntrip tinha um encontro bastante humano após as mesmas, quando conversavam sobre teoria e técnica:

Achei-o formal nas sessões, o analista de interpretações intelectualmente precisas. Mas, após as sessões, discutíamos teoria e ele se soltaria e eu encontraria o Fairbairn humano ao conversarmos face a face. Numa visão mais realista, era meu pai bom e compreensivo após as sessões e durantes as sessões, na transferência, era minha mãe ruim dominadora, impondo interpretações exatas. (Guntrip, 1975/2001, pp. 226-227)

Guntrip relatou então a Fairbairn os anos que se sucederam à morte de seu jovem irmão, Percy, que tinha apenas um ano de idade quando faleceu. Sua mãe recusava-se a aleitar Percy e dizia a Guntrip que apenas o amamentou porque pensava que assim evitaria outra gravidez. Foi a irmã mais velha de onze crianças, tendo sua mãe posto nela a responsabilidade de administrar o lar e cuidar de seus irmãos ainda muito cedo. Ao casar, estava já farta de cuidar de crianças e não planejava ter filhos, o que acabou acontecendo. Os motivos concretos para a morte de Percy não são relatados por Guntrip, mas a absoluta falta de amor dela pelo bebê nos é bastante clara.

Após a morte do irmão, Guntrip passou alguns anos tentando forçar sua mãe a se relacionar com ele, eventualmente desistindo e se afastando dela. Fairbairn interpretava essas experiências esquizoides - Guntrip sentia-se incapaz de amar em consequência da experiência de não poder ser amado - como uma fuga das relações com o objeto mau, elevando a situação a um contexto de conflitos edípicos, tema que gerou muita controvérsia entre os dois. Quando Guntrip tinha oito anos, sua mãe passou a ter sucesso em um negócio próprio, dedicando-lhe muito tempo, o que fez com que ele ficasse sob os cuidados de uma tia inválida que morava com a família.

O paciente relatou momentos em que foi acometido por misteriosas "doenças de exaustão", todas em situações relativas a pessoas que foram 
encontradas como substitutos de Percy em sua vida - um amigo da faculdade e um assistente que teve na igreja em que ministrava. Quando seu amigo foi embora e Guntrip foi passar férias na casa de sua mãe, caiu doente, recuperando-se prontamente quando retornou à faculdade. $\mathrm{O}$ mesmo ocorreu quando o assistente, que ficou muito próximo a ele, partiu devido à proximidade da Segunda Guerra Mundial. Alguns anos mais tarde, em 1957 (quando já estava, portanto, em análise com Fairbairn), Guntrip sofreu da doença misteriosa pela terceira vez, quando o mesmo amigo da faculdade subitamente faleceu, o que fez com que o material mais profundo emergisse com grande intensidade. Além disso, logo em seguida, Fairbairn caiu doente de uma séria gripe viral e quase morreu. Quando a análise foi retomada, algum tempo mais tarde, Fairbairn fez uma interpretação que Guntrip considerou crucial, segundo a qual, desde a doença, não ocupava mais o lugar da mãe má ou do pai bom, mas de seu irmão moribundo. A possibilidade da morte de Fairbairn, naquele instante, parecia intolerável a Guntrip, que vivenciou uma grande angústia de aniquilação, sem a possibilidade de ter alguém com quem falar caso ocorresse, de fato. Diante disto, Guntrip acabou por procurar Winnicott.

Uma diferença marcante entre os dois analistas nos é logo exposta por Guntrip. Segundo ele, Winnicott parecia mais disponível para um relacionamento natural e espontâneo do que Fairbairn, que a partir de suas próprias tendências esquizoides parecia intelectualizar excessivamente suas relações. Mesmo a descrição dos consultórios de ambos é pertinente:

O ambiente do consultório cria uma atmosfera que possui significado. Fairbairn vivia no campo e recebia seus pacientes na antiga casa da família Fairbairn em Edinburgh. [...] Fairbairn sentava por trás de uma escrivaninha ampla e plana, eu pensava, como um estadista, numa cadeira de braço alta e acolchoada. O divã do paciente tinha a cabeceira voltada para a frente da escrivaninha. Às vezes eu pensava que ele alcançaria por cima da escrivaninha e me bateria na cabeça. (Guntrip, 1975/2001, p. 229)

Quanto ao ambiente clínico de Winnicott, Guntrip conta o seguinte:

Seu consultório era simples, repousante nas cores e mobília, sem ostentação, cuidadosamente planejado, segundo a Sra. Winnicott me disse por ambos, de modo a deixar o paciente à vontade. Eu batia e entrava e logo chegaria Winnicott de xícara de chá na mão com um animado 'Hallo', sentando-se na pequena cadeira de madeira ao lado do divã. Eu me sentava no divã de lado ou me deitava, de acordo com a minha disposição, e mudava de posição livremente de acordo com o que eu sentia ou o que dizia. No final, sempre me esticava sua mão num cumprimento amistoso. (Guntrip, 1975/2001, p. 231) 
A pertinência da descrição de Guntrip sobre os consultórios de Fairbairn e Winnicott transcendem o valor da exposição da técnica de ambos ao estruturarem seu espaço. Ela nos mostra a percepção que tinha um paciente tão regredido a respeito do setting. As ansiedades vividas diante de um analista que, embora admirado, parecia não lhe compreender, com uma atitude distante, de onde a qualquer momento poderia vir uma pancada na cabeça (ou uma interpretação mal colocada) e, de outro lado, a atitude acolhedora de Winnicott, com o qual poderia sentir-se seguro e confortável para poder elaborar suas questões.

Na primeira sessão com seu novo analista, Guntrip contou-lhe sobre sua amnésia decorrente da morte de Percy, ao que Winnicott respondeu, quase no fim da sessão: "Não tenho nada em especial para dizer ainda, mas se eu não disser alguma coisa você pode começar a sentir que não estou nem aqui” (Guntrip, 1975/2001, p. 237). Essa fala de Winnicott pode ser compreendida, segundo Dias (2008), como uma interpretação adaptada à primitiva situação em que Guntrip se encontrava - como holding, em uma dimensão do manejo. Na sessão seguinte, Winnicott disse-lhe ainda:

Você me conhece mas ainda não sou uma pessoa para você. Você pode ir embora sentindo-se sozinho e que não existo de verdade. Você deve ter tido uma doença antes do nascimento de Percy e sentido que sua mãe havia deixado-o por sua conta própria. Você aceitou Percy como o seu self-bebê que necessitava cuidados. Quando ele morreu você não tinha mais nada e entrou em colapso. (Guntrip, $1975 / 2001$, p. 237)

Esta intervenção foi vivenciada por Guntrip como a perfeita interpretação de relação objetal. Dessa forma, foi capaz de estabelecer um vínculo menos ansioso com Winnicott, algo que se reflete também sobre como se lidava com a questão do silêncio nessa análise. Guntrip nos conta que sentia uma grande necessidade de manter-se falando, vivenciando os silêncios com grande angústia. Winnicott interpretou esse sentimento como um temor relativo a morrer num lapso como Percy, caso parasse por um momento. Mais ainda, se isso ocorresse, sua mãe não seria capaz de socorrê-lo, da mesma forma que não o fez com Percy. Winnicott diz então: "Você está amarrado ao medo de que eu não possa te manter vivo, de modo que liga as sessões mensais entre si para mim com suas anotações. Nada de lapsos" (Guntrip, 1975/2001, p. 238). Após essa ocasião, Guntrip foi tornando-se mais capaz de tolerar momentos de silêncio, ao mesmo tempo em que Winnicott 
ocasionalmente aliviava sua angústia ao mexer-se na cadeira, mostrando que estava presente. Assim, segundo Guntrip:

Winnicott, relacionando-se a mim no meu mais profundo inconsciente, permitiume ver que não foi apenas a perda de Percy, mas o ser deixado sozinho com a mãe que não podia me manter vivo, que causou meu colapso a um estado aparentemente mortal. Mas graças ao seu profundo insight intuitivo, não estava mais só com uma mãe que não se relacionava. (Guntrip, 1975/2001, p. 240)

Algum tempo depois, após ter se deparado com a possibilidade de precisar se aposentar devido a uma severa pneumonia (já estava então com 70 anos), Guntrip recebeu a notícia do falecimento de Winnicott, o que desencadeou uma série de sonhos que, aliados à revisão de suas notas sobre as sessões, romperiam então a amnésia.

Devemos, no entanto, destacar que a amnésia de Guntrip não se referia exatamente ao conhecimento do fato que ocorreu à época da morte de Percy. Sua mãe lhe relatara anteriormente: "Ela me disse que aos três anos e meio entrei no quarto e vi Percy deitado nu e morto em seu colo. Corri e agarrei-o e disse: 'Não o deixe ir. Jamais o terá de volta!' Ela me expulsou do quarto e eu caí doente misteriosamente e pensei estar morrendo" (Guntrip, 1975/2001, p. 232). O médico que o atendeu quando caiu doente, quando criança, disse que, se o senso materno de sua mãe não o salvasse, ele seria igualmente incapaz de fazê-lo. A mãe de Guntrip o levou então aos cuidados de uma tia maternal, com a qual acabou por recuperar-se. Nos diz Guntrip que "tanto Fairbairn quanto Winnicott pensavam que eu teria morrido se ela não me afastasse de si” (Guntrip, 1975/2001, p. 232).

A solução da amnésia de Guntrip ocorreu, na verdade, a partir da elaboração desse ocorrido. Quando criança, Guntrip não tinha à sua disposição meios (ou uma linguagem adequada) para criar uma representação do que presenciara, o que fez com que continuasse vivenciando esse trauma no presente. Isso somente foi possível devido ao cuidado suficientemente bom que teve, na relação transferencial, com Winnicott, o mesmo cuidado que sua mãe foi incapaz de lhe dispensar, da mesma forma que Fairbairn. Guntrip conclui seu artigo ressaltando a importância da adequação da técnica psicanalítica em casos como o seu: 
Se a nossa teoria for muito rígida, provavelmente estará conceituando as defesas do nosso ego. Se for flexível e progressiva, poderá conceituar nosso contínuo processo de crescimento, iluminar os problemas e possibilidades terapêuticas de outros. Uma vez que a 'falha básica' de Balint e o 'núcleo incomunicável' de Winnicott são considerados por eles como fenômenos universais, certamente devem constituir a forma deles de 'intuitivamente sentir' sua própria realidade básica e portanto a de outros. (Guntrip, 1975/2001, p. 245)

Percebemos, nos casos acima descritos, importantes aspectos do manejo clínico de Winnicott em casos limítrofes. O trabalho interpretativo, embora presente por vezes, era normalmente deixado à margem, enquanto a relação assumia grande importância. Mesmo as interpretações serviam a esse propósito, como podemos entender a partir das interpretações relatadas por Little e Guntrip. Uma importante característica das relações terapêuticas estabelecidas por Winnicott nesses casos é similar ao que Ferenczi havia descrito alguns anos antes como correspondendo a uma atitude de benevolência.

A ideia de uma benevolência inabalável já havia sido exposta pelo autor húngaro em artigo de 1927, O problema do fim da análise, quando destacou a importância de que o analista conserve essa postura diante do paciente, não importando quão incorretas possam parecer suas atitudes (como Little, ao destruir o vaso de Winnicott), já que isso poderia representar um teste baseado na reprodução de uma situação infantil: "Parece-me muito provável que os pacientes procurem repetir, por essas tentativas, situações de sua infância em que educadores e pais incompreensivos reagiram às chamadas 'maldades' da criança por meio de manifestações afetivas intensa, levando assim a criança a adotar uma atitude de recusa” (Ferenczi, 1927/2011, p. 24). Essa ideia, que parece constituir uma espécie de embrião que se desenvolveria anos mais tarde principalmente em Confusão de língua entre os adultos e a criança, expõe também o valor que Ferenczi percebia nos estados regressivos para a análise, o que levou a um duradouro desacordo com Freud. Assim, ao contrário da proposta da técnica ativa, de elevar a tensão do paciente, Ferenczi oferece posteriormente uma nova visão de setting, no qual o analista deve proporcionar um ambiente propício ao relaxamento (ou neocatarse), o que fortaleceria o vínculo terapêutico a partir de uma relação de confiança. A perda da confiança, por outro lado, implicaria em uma reprodução da violência do adulto agressor que traumatizou a criança na situação original. 
A confiança é percebida por Lejarraga (2008) como uma questão-chave para a clínica do trauma, como o fator que permite a regressão ao infantil. Na clínica ferencziana, somente através da regressão seria possível a elaboração do trauma, já que, não havendo uma representação na situação original, a linguagem verbal seria ineficaz para descrevê-lo: "O trauma não pode ser rememorado porque nenhum traço mnêmico subsistiu, nem mesmo no inconsciente" (Lejarraga, 2008, p. 125). O acesso ao trauma e a possibilidade de sua liquidação residiriam então na reprodução desse trauma no ambiente analítico, não como um retorno ao passado (como se propunha a análise das neuroses), mas o trazendo ao presente, de forma que se possibilitem sua percepção e descarga motora. A regressão ao infantil, na elaboração ferencziana, consistiria então em uma repetição modificada da situação traumática original em um ambiente adequado, confiável e, principalmente, presente de forma sincera. Ferenczi sugere, em 1928, a ideia de tato psicológico, descrito como uma capacidade de "sentir com", um tipo de relação em que o analista se permite uma proximidade com o paciente e aceita a identificação que este experimenta com ele - quase como se vivenciasse algo próximo ao estado fusional que seria descrito por Winnicott nas psicoses de transferência. Lejarraga assim sugere: "O terapêutico reside, assim, por um lado, no elemento inédito: a dor do trauma - a criança ferida - pode ser, 'pela primeira vez', revivida e sentida pelo indivíduo, o que tende a reunificar os pedaços clivados do eu. Por outro lado, essa vivência só se torna terapêutica se for compartilhada com um analista 'simpático' e compreensivo" (Lejarraga, 2008, pp. 126-127).

Embora adotem uma fundamentação teórica particular que sustenta suas respectivas e diferentes práticas, é possível encontrar muitas similaridades entre as propostas clínicas de Winnicott e Balint - talvez ambos encontrem em Ferenczi seu denominador comum. Por outro lado, Balint oferece uma concepção diferente e muito valorosa a respeito das formas de regressão na análise. Como nos informa Peixoto Junior (2013), Balint conserva as quatro funções da regressão que Freud descrevera: como mecanismo de defesa, forma de resistência, importante fator do trabalho analítico e mecanismo patológico. No entanto, destaca a diferença entre esses dois autores:

[...] enquanto em Freud a regressão permanece fundamentalmente intrapsíquica, em Balint ela será vinculada à teoria da relação de objeto e à psicologia a duas 
pessoas, tanto no campo teórico quanto na prática psicanalítica. Assim a regressão perde o caráter pejorativo que tinha adquirido na obra de Freud em que, à exceção do caso Dora, ela se destacava justamente a partir de seus aspectos negativos [...]. (Peixoto Junior, 2013, pp. 63-64)

Balint aproxima-se, portanto, da visão ferencziana, especialmente no uso da regressão como ferramenta terapêutica com pacientes difíceis, como os de Ferenczi. Segundo Balint (1969), uma das mais importantes funções do analista consiste em oferecer um meio tranquilo e seguro, no qual o paciente tenha uma confiança suficiente para retornar a um estado análogo a uma condição anterior que teria sido perturbada por uma falha do ambiente. Proporcionar essas condições significa permitir ao paciente uma nova oportunidade, uma segunda chance, agora sustentada por um ambiente adequado, para que o sujeito reencontre seu curso de desenvolvimento.

A regressão pode remeter a diferentes níveis, de acordo com a divisão proposta por Balint quanto às áreas da mente. Conforme discutido no capítulo anterior, elas são três: a área da criação, a área da falha básica e a área do conflito edipiano. Devemos considerar que a regressão no ambiente clínico descrita por Balint remete, normalmente, aos níveis da falha básica e ao edipiano, uma vez que a área da criação não comportaria a transferência devido à ausência de objetos, embora Balint (1969) considere que o silêncio do paciente possa representar um fenômeno desse âmbito. A profundidade da regressão varia de acordo com a localização do trauma, sendo possível atingir resultados bastante satisfatórios com alguns pacientes ainda na dimensão edípica através da técnica tradicional. Contudo, o outro extremo de pacientes necessita de um processo mais profundo, a partir de um período de regressão variável quanto à sua duração, mas sempre de natureza mais primitiva.

Na regressão ao nível edipiano, as palavras conservam seu valor, a linguagem adulta é adequada e compreendida tanto pelo analista quanto pelo paciente. As interpretações são recebidas pelo paciente como tal, algo somente possível quando as palavras possuem aproximadamente o mesmo significado para ambos na situação analítica. Neste caso, até mesmo o material pré-genital pode ser elevado ao nível verbal de modo a ser elaborado. O nível da falha básica, contudo, é mais simples, mais primitivo do que o nível edípico, e nele é utilizada uma 
linguagem diferente daquela do mundo adulto. Pelo contrário, a linguagem adulta pode ser enganosa ou mesmo inútil; a interpretação (verbal) pode não ser clara para o paciente ou nem mesmo experienciada como tal - o que é mais marcante para o paciente é o afeto carregado naquela interpretação, o que faz com que possa ser percebida como um ataque, uma invasão, uma demanda ou mesmo uma tentativa de sedução. A grande questão para o paciente regredido ao nível da falha básica, portanto, transcende a linguagem verbal estrita, as palavras, baseando-se principalmente na qualidade da relação estabelecida entre analista e paciente.

De uma forma geral, os estados regressivos tendem a buscar o retorno a um estado caracterizado por uma relação harmoniosa interpenetrante com o ambiente, própria ao que Balint denominou de amor primário. Esta harmonia, durante o desenvolvimento emocional inicial, é quebrada quando ocorre uma alteração no ambiente, forçando o indivíduo a uma nova forma de adaptação que inicia a separação entre ambos.

Balint considera esta alteração o grande e fundamental trauma da vida emocional precoce, constituindo o principal ponto de fixação ao qual a regressão se dirige. Para possibilitar a elaboração desse trauma, é importante que o analista se mostre disponível e presente ao desenvolver uma atmosfera propícia à regressão, marcada pela confiabilidade - aquela que Balint chama de arglos.

Esta disponibilidade não significa que o analista deve demarcar sua presença através de interpretações, pelo contrário. Como o estado regredido indica um nível pré-verbal, o analista deve simplesmente se mostrar vivo e presente, de forma consonante com a que Winnicott descreve, ao longo de sua obra, a postura do analista diante de um paciente regredido a um estágio primitivo. De acordo com Peixoto Junior,

Trata-se, neste caso, de 'atravessar o abismo' que separa o adulto no analista da criança no paciente. Como na área da falha básica as expressões não verbais (comportamentos, repetições e acting outs) adquirem a mesma importância das comunicações verbalizadas, uma das principais tarefas do analista é a de traduzir para o paciente seus comportamentos primitivos que ainda prescindiam da linguagem, não apenas como um intérprete, mas como o que Balint chama de 'informante', ajudando o paciente a se dar conta do que vinha fazendo na situação analítica. (Peixoto Junior, 2013, p. 65) 
Enquanto Winnicott, ao longo das passagens em que relata o caso de Margaret Little, destaca que seu trabalho consistia mais em sobreviver de forma não intrusiva através, por exemplo, do som de sua respiração, sustentando a paciente no setting, Balint (1959) cita um paciente em estado regredido que pediulhe que não falasse nada, mas que ocasionalmente fizesse algum barulho, ao se mover, fazer a cadeira estalar, ou mesmo ao respirar - assim, o analista se faria presente respeitando a regressão ao não recorrer ao mundo adulto das palavras - de forma semelhante ao que pode ser encontrado no relato de Guntrip. Ainda sobre o silêncio, Balint (1969) relata um outro caso em que o paciente permaneceu sem nada falar desde o início da sessão, por mais de trinta minutos, após os quais, diante da aceitação do analista a esse silêncio, começou a chorar, podendo dizer logo em seguida que pela primeira vez pôde se encontrar. Nunca havia sido deixado sozinho desde a infância, havia sempre alguém a lhe dizer o que fazer. Balint nos sugere então diversas possíveis interpretações à situação - entre outras, como resistência, retraimento, angústias persecutórias - e afirma que todas poderiam estar corretas. No entanto, “[...] teriam destruído o silêncio e o paciente não teria sido capaz de 'se alcançar', em qualquer nível, não naquela ocasião" (Balint, 1969, p. 178). Segundo Bonaminio (2008/2008) a interpretação nesse contexto teria sido intrusiva, destruindo a possibilidade de que o paciente criasse algo. Ao aceitar o silêncio nesse contexto, Balint permitiu que o paciente ficasse sozinho na presença de um analista não intrusivo - o que encontra um importante paralelo com noção winnicottiana da capacidade de estar só. Winnicott (1958/1983) considera essa competência um importante sinal de amadurecimento emocional. Trata-se de algo relativo à experiência infantil de ficar só na presença da mãe, o que configura um paradoxo. Ainda assim, a aquisição desta capacidade, em momentos posteriores, representa a possibilidade de se apreciar a solidão na presença de outro que não é sentido como tal - inclusive, se fosse de fato percebido como outro, o sujeito não estaria só. A capacidade para estar só se refere, portanto, a usufruir dos estados não-integrados a partir do relaxamento, redescobrindo o impulso pessoal. Como o nos diz autor inglês: "É somente quando só (isto é, na presença de alguém) que a criança pode descobrir sua vida pessoal própria. A alternativa patológica é a vida falsa fundamentada em reações a estímulos externos" (Winnicott, 1958/1983, p. 35). No mesmo artigo, Winnicott sugere que é possível que o paciente, ao experienciar o silêncio na sessão analítica demonstre uma importante conquista - talvez seja a 
primeira vez que esteja vivenciando a experiência de ficar só, como parece que foi o caso do paciente de Balint. É importante destacar, no entanto, que o silêncio não era uma situação nova nesse caso, tanto paciente quanto analista já haviam se deparado com ele no setting e eram capazes de suportá-lo. Essa postura de parte do analista corresponde então ao que Balint chama de analista não intrusivo, aquele que respeita a realidade psíquica do paciente, apenas observando quando necessário:

$\mathrm{Na}$ linguagem de Balint esta é a posição do analista não intrusivo (unobtrusive): a única coisa que sabemos é que o processo de criação é imprevisível. O exemplo é aquele do paciente silencioso que está criando alguma coisa, algo que o analista não pode saber e que não pode ser compartilhado enquanto está sendo criado; o analista pode somente permanecer com ele olhando-o de fora durante a sua obra. (Bonaminio, 2008/2008, p. 184)

A constância do analista representa, para Balint, um dos pontos fundamentais da técnica psicanalítica para lidar com estados regressivos. É a continuidade do analista e do setting como um todo que permite que se estabeleça uma relação de confiança, base para que a regressão seja tanto alcançada como mantida sem que constitua uma ameaça à estrutura psíquica. Não obstante, é importante ressaltar que esta base de confiança pode ser perturbada por um trabalho interpretativo a nível verbal, o que pode ainda impedir a manutenção da regressão. Ao discorrer sobre analistas intolerantes com a regressão, que a interpretam como uma fuga do trabalho analítico, Balint elucida:

Outro grupo de analistas, menos rígidos em sua abordagem, podem tolerar regressões desse tipo, mas, talvez involuntariamente, forçam o paciente para fora delas por interpretações que seriam corretas em outro contexto, já que a aceitação e o entendimento de tais interpretações exigem do paciente muito mais maturidade do que este estado de regressão comporta. Embora a regressão possa ser alcançada por curtos momentos, não podem ser mantidas pelo paciente, e talvez ainda menos reconhecidas pelo analista. Este tipo de trabalho analítico é mantido principalmente no nível verbal, permitindo vislumbres dos estados pré-verbais tranquilos, não-excitados, mas não admitindo que o paciente submerja neles durante qualquer período de tempo. (Balint, 1959, p. 101)

Este tipo de postura por parte do analista pode provocar no paciente um imenso desespero, já que este não reconhece um ambiente harmônico na situação analítica - há atrito demais entre as partes. Nas situações de regressão, o analista 
deve apenas agir como uma substância que sustenta o paciente, indestrutível como os elementos básicos pré-socráticos - água, terra, fogo e ar -, mas não através de uma ação propriamente, e sim pelo envolvimento afetivo:

A substância, o analista, não deve resistir, deve consentir, não deve provocar muita fricção, deve aceitar e carregar o paciente por um tempo, deve provar-se mais ou menos indestrutível, não deve insistir em manter limites rigorosos, mas permitir o desenvolvimento de um tipo de mistura entre o paciente e ele mesmo. Tudo isso significa consentimento, participação e envolvimento, mas não necessariamente ação, somente entendimento e tolerância; o que realmente importa é a criação e a manutenção de condições nas quais eventos possam ocorrer internamente, na mente do paciente. (Balint, 1969, p. 145)

Segundo Balint, essa atitude do analista é o que permite o estabelecimento de um dos mais importantes fenômenos clínicos em situações regressivas, conceito que o autor chama de "novo começo". Trata-se de oferecer ao paciente uma nova oportunidade de retomar certo tipo de relação que precisou ser abandonada devido ao fracasso ambiental em atender as demandas amorosas do sujeito. Agora, no entanto, o analista oferece um ambiente mais seguro, adequado e adaptado, que viabiliza o prosseguimento do curso que fora interrompido. Balint define o novo começo da seguinte forma:

Novo começo significa: (a) voltar a algo 'primitivo', a um ponto anterior ao início do desenvolvimento defeituoso, o que poderia ser descrito como uma regressão, e (b), ao mesmo tempo, descobrir um novo e mais adequado caminho que leve a uma progressão. Em meu livro Thrills and regressions (1959) nomeei a soma total desses dois fenômenos básicos: regressão em favor da progressão. (Balint, 1969, p. 132)

Dessa forma, a regressão benigna é descrita por Balint (1969) como uma busca por reconhecimento dos problemas internos, algo que ocorre internamente sem exigir a ação do analista, apenas seu acolhimento. $\mathrm{O}$ atendimento dessas demandas proporciona ao paciente um resgate de algo primitivo, o que possibilita considerável diminuição na angústia e uma mudança no ego através de uma regressão provida de real valor terapêutico. É possível considerar que essa ideia evidencia certo otimismo da parte de Balint, o que contrapõe sua orientação clínica, segundo Bonaminio (2008/2008), à posição pessimista ou cautelosa de Freud, destacando sua proximidade com Ferenczi. No entanto, Balint identifica também um outro tipo de regressão, em que o paciente não alcança qualquer tipo de progresso terapêutico e a análise permanece estagnada, baseada em uma repetição sem qualquer valor elaborativo. Como exemplos, Balint (1969) cita os recorrentes 
pedidos de sessões extras e prolongamentos de sessões, sem que qualquer trabalho seja concretamente realizado neste espaço - tais demandas são tão poderosas que eclipsam o próprio trabalho analítico. O autor chama esse fenômeno de regressão maligna, uma defesa relativa ao cerne emocional do sujeito. Esta, ao contrário da regressão benigna, envolve uma busca por gratificações e satisfações pulsionais, exigindo intermináveis ações por parte do analista, ou seja, que ocorrem a partir do mundo externo. Ademais, ainda que sejam atendidas, tais demandas nunca são de fato satisfeitas - apenas evocam o surgimento de novas exigências. Assim, o paciente entra em um ilimitado ciclo do qual somente se pode sair com muita dificuldade.

Podemos interpretar a noção balintiana de regressão maligna como uma problematização das técnicas mais tardias de Ferenczi. Este optou por abrir mão da atmosfera de privação e tensão pulsional da técnica ativa (apoiada nos conceitos freudianos) em benefício de uma relação na qual gratificava os anseios do paciente, criando um ambiente de relaxamento. De acordo com Peixoto Junior:

Sua hipótese era a de que a gênese das patologias psíquicas encontrava-se em situações traumáticas da infância, ou, mais precisamente, no contexto da confusão de línguas entre adultos e crianças. Isso o levava a acreditar que a situação analítica recriava as necessidades e demandas do passado, provenientes da situação traumática original, na atualidade da relação com o analista, que permanecia em estado de distanciamento simpático com relação a seu paciente. Daí Ferenczi ter ensaiado numerosas técnicas que pudessem auxiliar o sujeito a lidar com essas situações regressivas. (Peixoto Junior, 2013, p. 67)

Balint (1969) declara que a ocorrência de um ou outro tipo de regressão depende do paciente - sua personalidade, estrutura egoica e a patologia em si. Todavia, seu sucesso dependerá da resposta do analista frente à regressão do paciente, através de sua técnica. Isto adquire grande relevância, especialmente ao considerar que o autor percebe a regressão como um fenômeno interpessoal, e não intrapsíquico - ela ocorre a partir da confluência entre analista e paciente. A identificação do tipo de regressão e seu manejo apropriado na clínica seriam de extrema importância, portanto, para o desenrolar da análise do sujeito.

Descrevemos, ao longo deste capítulo, as inovadoras propostas de Ferenczi, Balint e Winnicott a respeito do manejo envolvido em casos regressivos, em especial diante de pacientes cujo trauma remete a momentos mais iniciais do 
desenvolvimento, o que exige que o tratamento analítico perpasse um nível mais profundo que o verbal. As ideias desses autores serviriam de referência para as futuras gerações psicanalíticas, como veremos no capítulo a seguir, a partir da exploração de algumas considerações a respeito da clínica do trauma e da regressão analítica segundo a psicanálise contemporânea. 


\section{Perspectivas contemporâneas sobre a clínica do trauma}

Podemos perceber que as contribuições de Ferenczi, Balint e Winnicott ecoaram entre a comunidade psicanalítica até os dias de hoje, seja através do resgate da teoria ferencziana por psicanalistas como Franco Borgogno, Judith Dupont e Thierry Bokanowski; pela apreciação de Balint por Harold Stewart e Vincenzo Bonaminio; ou pela influência de Winnicott nas obras de Stefano Bolognini, Christopher Bollas e Thomas Ogden por exemplo. Ainda assim, cada um desses autores imprimiu sua própria visão, percebendo a relevância das teorias desses psicanalistas clássicos (entre outros) em um contexto contemporâneo.

Neste último capítulo, exploraremos as ideias de alguns desses autores, Christopher Bollas, Thomas Ogden e Stefano Bolognini, escolhidos devido à pertinência de suas propostas no campo clínico ao lidar com a análise dos traumas, especialmente quanto às necessidades do paciente de atravessar um estado regressivo. Da mesma forma, perceberemos a grande diferença entre a abordagem clínica desses dois autores a respeito da análise de casos que envolvem sofrimentos primitivos.

\subsection{Christopher Bollas e a psicanálise do colapso}

Bollas é um psicanalista norte-americano - nasceu na Califórnia e lá foi criado durante a Guerra Fria, mas mudou-se em 1973 para Londres, onde desenvolveu grande parte de sua prática. Integrante da Sociedade Britânica de Psicanálise, ele vem oferecendo suas inovadoras e arrojadas ideias a respeito da clínica psicanalítica desde os anos 70. Portador do título de Doutor em Literatura pela Universidade de Buffallo, em Nova York, Bollas imprimiu uma estrutura literária nos seus escritos psicanalíticos. Dentre as principais influências de Bollas, Nettleton (2016) cita, além de uma profunda leitura de Freud, Wilfried Bion, Jacques Lacan, Heinz Kohut e Winnicott, autor que foi muito caro ao californiano, como fica claro a partir das referências que ele utilizou ao longo de sua obra. Encontramos diversas referências também a Balint e Frances Tustin em seus escritos. No entanto, Bollas nos mostra uma interessante reverência a Winnicott reconhecendo sempre sua importância e as grandes inovações que proporcionou no 
campo clínico, mas nunca de forma cega, sempre questionando a aplicabilidade de seus conceitos - como o faria, por exemplo, quanto ao uso da regressão no ambiente analítico com pacientes borderlines da forma que havia sido descrito pelo psicanalista inglês. Ferenczi também parece ter influenciado Bollas, principalmente no que se refere ao conceito de "objeto transformacional" (Bollas, 1978), ao qual também é possível atribuir um pano de fundo winnicottiano. Neste trabalho, Bollas (1978) descreve o desenvolvimento de um idioma no momento inicial da vida, quando a realidade da criança é governada pela forma com que o ambiente responde às suas necessidades, ou seja, pela capacidade da mãe em cuidar dela. A contínua participação materna promove alterações no estado do self do bebê, sendo experimentada, assim, como um objeto transformacional. A busca por esse tipo de relação, de acordo com o autor (1978), persiste na vida adulta, seja na crença em deidades ou mesmo no crime: "Um criminoso busca o crime perfeito para transformar o self internamente (consertando defeitos do ego e satisfazendo necessidades do id) e externamente (trazendo riqueza e felicidade)" (Bollas, 1978, p. 4). No entanto, podemos entender que esse objeto transformacional pode ser encontrado ainda na figura do analista.

Em seu livro Catch them before they fall, de 2013, Bollas sugere um novo tipo de trabalho para um antigo tipo de paciente, aquele que se encontra ou à beira de um colapso ou já colapsado. É interessante destacar que o autor oferece essa nova formulação em um contexto absolutamente contemporâneo, com críticas pertinentes a práticas médicas e psicológicas da atualidade.

Primeiramente, Bollas reprova a forma com que os profissionais da área da saúde, como um todo (especialmente nos Estados Unidos), lidam com pacientes em situação de colapso. Existiria uma tendência, na ótica do autor, a negar ou mesmo adiar o colapso - a psiquiatria recorreria imediatamente à medicação como forma de evitar esse tipo de sofrimento, silenciando os sintomas do paciente que clamam pela escuta de alguém; enquanto algumas psicoterapias (Bollas cita nominalmente a Terapia Cognitivo-Comportamental, ou TCC) colocariam a vida interna do paciente de lado ao desviar a sua atenção para um projeto cognitivo temporário - como no caso de um pai ou mãe que lida com o choro de seu bebê 
dizendo "Nossa, olhe só aquilo!" para que ele simplesmente pare de chorar. Segundo Bollas, esse tipo de distração

[...] esvaziará o self e, por um tempo, fechará as rachaduras, frequentemente para o alívio do paciente, das estatísticas do hospital e do Estado, que está preocupado com o self eficiente quanto aos custos. Mas para aqueles que entendem o colapso como uma experiência profundamente humana, distrair o self dos significados de sua fragilidade produz uma nova forma particular de perda. É muito cedo nesse século para saber os efeitos a longo prazo desses tratamentos superficiais, embora eu acredite que é irresponsável deixar o tempo dizer. Pessoas em colapso não precisam de alguém que desvie seu olhar do mundo interno para um livro de autoajuda como dever de casa, elas precisam ser ouvidas e entendidas a partir das profundezas do self que por elas são apresentadas, as quais constituem sua crise. (Bollas, 2013, pp. 2-3)

É importante definir, nesse sentido, a respeito de que tipo de paciente Bollas se refere nessa nova proposta. Não se trata de pacientes psicóticos, pelo contrário, são pessoas que seriam normalmente classificadas como "comuns". O próprio colapso não presume necessariamente um surto de natureza psicótica, mas um momento de grande sofrimento e uma situação psíquica bastante delicada. Como nos diz o autor (2013), são circunstâncias altamente não usuais que exigem medidas igualmente peculiares. O colapso, na visão de Bollas, não deve ser negado, mas aproveitado como uma importante oportunidade de avanço:

O resultado de um colapso não é necessariamente uma descida em descompensação psicótica, embora isso possa ocorrer. Mais comumente, pessoas que sofrem um colapso [breakdown], o qual não é transformado, na hora, em um avanço [breakthrough], tornam-se o que chamo de selves partidos [broken selves]. Essas pessoas então funcionam de formas significativamente diminuídas pelo resto de suas vidas. Podem ser diagnosticadas como esquizoides, esquizoafetivas ou cronicamente deprimidas, mas demonstraram esses sinais, de fato, apenas após o colapso. (Bollas, 2013, p. 5)

Este tipo de funcionamento, em um nível baixo, mantém-se tanto na atividade profissional do sujeito - em termos de produtividade, por exemplo - como em âmbito afetivo, relacional e pessoal. Essa ideia fica bastante clara nos pacientes descritos por Bollas, como veremos adiante. No entanto, para melhor compreender essas pessoas, devemos explorar mais profundamente o conceito de self partido.

\subsubsection{Selves partidos}

Bollas nos explica que, embora muitas práticas se valham de um esforço psicodiagnóstico quanto ao paciente (incluindo nisso a psicanálise, com seus 
diagnósticos particulares - histérico, obsessivo, esquizoide, depressivo, por exemplo), sempre que um analisando a ele se apresentasse de uma dessas formas, Bollas considera que o que estava realmente percebendo era que algo havia acontecido com essa pessoa. No caso, este algo era que esse sujeito teria um self partido, definido por Bollas da seguinte maneira:

Por 'self' partido não estou me referindo a um diagnóstico especifico nem sugerindo uma nova categoria de patologia. $\mathrm{O}$ termo deve ser aplicado a um amplo espectro de pessoas, incluindo aqueles que chamaríamos de 'normais'. O único denominador comum entre eles é que sofreram um colapso, frequentemente na idade adulta inicial, durante o qual foram deixados sem cuidado terapêutico adequado. Independente dos caminhos de sua infância, as fraquezas inerentes de seu ego ou suas estruturas mentais, foi esse colapso na vida adulta que deixou uma cicatriz distinta em seu ser. (Bollas, 2013, p. 14)

Segundo o autor, esses pacientes costumam chegar à análise por volta de seus trinta ou quarenta anos e não foram capazes de responder a qualquer terapia (inclusive a analítica) porque desistiram da vida. Terapeutas são incapazes de alcançar qualquer sucesso significativo com eles, exceto algumas raras ocasiões, através de pontuais expressões de gratidão. Bollas acredita que tais casos somente lhe foram apresentados por seus supervisionandos pelo desespero deles, ao perceberem que nada se provava eficaz. Todos estes pacientes haviam passado por algum tipo de colapso não psicótico, possivelmente ocasionado por um evento exógeno, em situações cotidianas:

O colapso pode acontecer na universidade, na mistura das agitadas circunstâncias que costumam ocorrer nesse ambiente. Ou, após a graduação, quando a pessoa espera entrar no mercado de trabalho, pode haver uma série de rejeições e, após um esforço para continuar seguindo em frente, um colapso. Ou talvez um relacionamento que resistiu durante os anos colegiais termina subitamente, deixando o indivíduo abandonado, desolado e incapaz de se recuperar da perda. Ou talvez um pai, irmão ou amigo próximo morre, levando a um luto catastrófico. (Bollas, 2013, p. 15)

No entanto, até um evento sutil pode ocasionar o colapso, como uma multa de trânsito, por exemplo. Bollas afirma então que somente através da análise é possível compreender o efeito pernicioso do evento, uma vez que este, por si só, não seria capaz de proporcionar o esfacelamento do self. De qualquer forma, um grande risco percebido pelo autor nessa situação é a possibilidade de que não haja um elemento de apoio no entorno do sujeito - como o ambiente falho é normalmente o que propicia o colapso, é importante que haja um analista capaz de lidar adequadamente com as necessidades do paciente. 
Quando o colapso ocorre, tornando-se estrutural, a personalidade revolve ao redor dos efeitos do evento, fazendo com o que o self se reestruture de modo reduzido para manter seu funcionamento e garantir sua sobrevivência. Assim, o sujeito recorre a um retraimento psíquico, retirando-se do mundo objetivo. As noções que haviam sido afirmadas em uma infância suficientemente boa - como, por exemplo, a de que será possível encontrar ajuda quando necessária - são substituídas por novas, como descreve Bollas:

É melhor não buscar a ajuda de ninguém.

Se sou vulnerável, devo eliminar sentimentos.

Somente uma posição retraída pode ser segura.

Devo desinvestir o mundo objetal e abandonar uma relação com a realidade.

Renunciarei a ambições, planos, esperanças e desejos.

Devo encontrar pessoas que estão em uma situação similar e viver em uma nova sociedade de selves igualmente partidos. (Bollas, 2013, p. 16)

Notamos que o indivíduo partido de Bollas assume uma indiferença na vida nutrida por um profundo sentimento de desesperança. No entanto, o autor salienta que essa atitude nada tem a ver com a pulsão de morte, mas com o âmbito relacional - trata-se da perda de confiança no mundo, que não será capaz de reconhecer suas necessidades. Isso seria percebido inclusive no ambiente analítico, através das reações do sujeito às interpretações - pouca responsividade, pode dizer apenas "não sei", mostra pouca introspecção ou interesse nos significados de seu desespero: "Eles demonstram uma dor mental de baixo nível, um silencioso desespero depressivo, mas nenhum interesse no que isso pode significar. É puramente evacuativo" (Bollas, 2013, p. 18). Quanto à relação estabelecida na análise, o paciente partido assume certa distância do analista, embora demonstre uma intensa aderência à análise em si - segundo Bollas (2013), nota-se um medo de que ocorra um novo colapso, tratando a conexão com o analista da mesma forma desprovida de afeto com que se trata uma apólice de seguro. Estaríamos diante, então, de uma transferência neutra.

O sujeito recorre, dessa forma, ao mundo interno dos objetos fantásticos, voltando-se para planos e objetivos que não tem condições de serem atingidos, como escrever um romance ou tornar-se um empreendedor. De acordo com o autor, o sujeito sequer toma uma atitude para correr em busca desses sonhos: “[...] esses planos funcionam como projeções do self partidos: sonhos partidos que exemplificam a impossibilidade do sucesso" (Bollas, 2013, p. 18). Contudo, ao 
mesmo tempo, o sujeito mantem um self ideal oculto que funciona como um companheiro imaginário defensivo - os aspectos do self anteriores ao colapso. Bollas, por outro lado, destaca que essa ideia é diferente daquela de Winnicott a respeito do falso self - o self oculto de Bollas é fantasmático, um símbolo daquilo que o sujeito pensou que se tornaria.

$\mathrm{O}$ autor relata ter-se dado conta da quantidade de pacientes que se encaixam nessa categoria após uma considerável quantidade de fracassos clínicos, dos quais destaca dois. Tim era um jovem que foi atendido por Bollas na clínica em que trabalhava por um curto período de tempo - nesse momento, Tim era alguém que, embora estivesse em grande sofrimento após o término de um relacionamento amoroso, dava sinais de que emergiria da crise. Após a saída de Bollas dessa clínica, o paciente continuaria a frequentá-la, entregue aos cuidados de outros terapeutas. Sete anos depois, Tim pediu para encontrar-se com Bollas, que perceberia seu antigo paciente desprovido da vitalidade de outrora. Outra paciente é lembrada pelo autor, chamada de Lila, uma mulher com pouco mais de trinta anos que era atendida cinco vezes por semana. Durante um período que durou alguns meses ao longo do segundo ano de análise, Lila, anteriormente uma mulher bem articulada e reflexiva, tornou-se extremamente agitada, incapaz de concatenar suas ideias no discurso. Bollas considera então que se tivesse oferecido sessões adicionais a Lila, poderia ter lidado com este colapso de forma diferente, mudando sua vida. Com o sentimento de fracasso diante desses dois pacientes, entre outras situações similares, Bollas se propôs a alterar radicalmente sua técnica para abarcar esses tipos específicos de sofrimento.

\subsubsection{A clínica do colapso: uma nova visão do setting}

$\mathrm{O}$ autor considera que uma questão fundamental para lidar com pacientes em situação de colapso é a capacidade do analista em reconhecer os sinais do paciente sobre o estado em que se encontra: se há um colapso por vir ou já acontecendo. Para ilustrar essa noção, Bollas nos oferece uma bela metáfora musical. Da mesma forma que conhecer bem certo compositor torna possível desenvolver uma ideia da forma da sua música, também é praticável entender a forma do material psíquico do paciente conforme o analista o conhece melhor. Assim, 
[...] se o analisando inconscientemente introduz uma diferença sutil de seu idioma corrente, ela será registrada pelo analista. Esse registro será subliminar a princípio, mas conforme se repete ao longo do tempo a diferença se marcará como um padrão, e isso levantará um certo sinal de ansiedade no analista, como se um fragmento de Brahms aparecesse no meio de uma sonata de Mozart. (Bollas, 2013, pp. 21-22)

Essa mudança no padrão, difícil de identificar precisamente, mas ao mesmo tempo bastante clara para o analista mais atento, indica alguns sinais de alerta da parte do paciente de que algo está para acontecer. Utilizando uma segunda metáfora, é como as mudanças no ar que precedem uma tempestade. Bollas (2013) sugere que existem dois tipos de colapso.

No primeiro, ocorre um período de transição, que pode durar dias ou semanas, em que o self gradualmente se dirige ao colapso - nessa situação, a pessoa sabe que algo está acontecendo, embora não saiba exatamente o quê. Bollas considera que um sinal recorrente é alteração no padrão de fala do paciente - tornase mais lento e hesitante, assim como seus movimentos, algo perceptível até mesmo na forma com que caminha pela sala até o divã. Seria importante que o analista, assim que notasse essas indicações, oferecesse cobertura psicanalítica adicional, antes que o desamparo venha a se estabelecer.

O segundo é um colapso súbito, sem indicações prévias, com efeitos arrebatadores. Este, segundo o autor, é mais comum em pacientes consideravelmente vulneráveis, mas rigidamente defendidos. Nesse caso, o analista deve adotar prontamente uma postura inquisitiva:

Nessa situação é crucial que o analista descubra em detalhes o que ocorreu nos dias anteriores que poderiam ter precipitado a catástrofe mental. Sempre haverá tal evento, mas eu nunca conheci um paciente que queria descrevê-lo. $\mathrm{O}$ analista, portanto, deverá estar pronto para ouvir a palavra 'nada' por muitas vezes. (Bollas, 2013, p. 24)

O autor ainda acrescenta:

A postura do analista deve, então, mudar - ser inquisitivo. Essa colheita de informações é crucial para o que virá em seguida. Devemos notar que nesse estágio não é afeto o que é necessário, mas informação. Perguntar a uma pessoa como ela se sente é contraproducente e produzirá abstrações vacilantes. (Bollas, 2013, p. 25)

Todavia, Bollas informa que o analista deve esperar até perceber que o paciente está em uma posição mais favorável para falar, e se isso parecer que vai 
levar mais tempo do que o que resta na sessão, deve-se oferecer mais tempo “Tempo é a variável crucial para o quão bem se pode ajudar um paciente que está no limite do colapso" (Bollas, 2013, p. 25). Essa afirmação poderia, entretanto, levantar um válido questionamento, uma vez que esse prolongamento afetaria o horário do paciente que virá a seguir. A partir da teoria de Bollas, em um nível mais amplo, por outro lado, deveremos presumir que o analista é responsável pelo reconhecimento das necessidades do paciente, admitindo a possibilidade da extensão do horário da sessão. Poderíamos acrescentar então, que mais do que o tempo, a capacidade de lidar com a temporalidade do paciente, isto é, o ritmo com o qual o mesmo é capaz de manifestar e elaborar seus conteúdos internos, é fundamental para o sucesso do trabalho analítico. Podemos encontrar um interessante paralelo com a teoria winnicottiana, uma vez que o enquadramento, como vimos no capítulo anterior, confere uma dimensão integradora à experiência analítica - ao deparar-se com a iminente desintegração do paciente, Bollas oferecelhe mais tempo de sessão, reconhecendo as necessidades do paciente e adaptandose a elas. O autor considera que é isso o que "segura" (no sentido da palavra inglesa catch, como no título do livro) o analisando antes que ele se desintegre, mas podemos entender também que o "segura" no sentido da palavra hold, a partir da provisão de suporte a partir do analista a nível espacial (o ambiente clínico) e temporal (o tempo da sessão durará tanto quanto necessário). Sobre esse tipo de eventualidade, ao relatar o caso de Anna, que será abordado adiante neste capítulo, Bollas explica ainda que, ao notar os sinais de que a paciente estava entrando em colapso, afixou em sua porta um bilhete informando que devido a imprevistos, estaria indisponível pelo resto do dia.

Dessa forma, como se trata de um trabalho psicanalítico sob circunstâncias anormais, é necessário que se dispense um cuidado maior em relação aos detalhes da alteração do setting. Bollas descreve que, ao deparar-se com pacientes que exibiam sinais de um colapso progressivo, oferecia sessões adicionais, em complemento às cinco sessões semanais que já conduzia - primeiramente, uma sessão adicional por dia, após o expediente do analista e, caso necessário, ampliando para duas sessões ao dia, sete dias por semana. Aos casos de colapso súbito, Bollas oferecia sessões de dia inteiro (all day sessions), que duravam de 9:00 às 18:00, durante três dias seguidos (sexta-feira, sábado e domingo, os dias 
nos quais o psicanalista não costumava trabalhar). Os pacientes que se submetiam a esta forma de trabalho, segundo ele, tiveram sua análise abreviada, durando a terapia subsequente não mais do que quinze meses, tempo dedicado à elaboração do término do processo analítico, sem que lhes fosse necessário uma nova análise posterior.

O autor salienta que esse tipo específico de análise exige uma considerável equipe que apoie o trabalho do analista em diferentes campos, relatando a participação de psiquiatras, clínicos gerais, assistentes sociais e até mesmo um motorista de sua confiança, que se responsabilizaria pelo transporte do paciente de sua residência às sessões, aguardando para levá-lo de volta para casa. Bollas sugeriria ainda que o paciente comunicasse algum familiar de confiança a respeito do momento que atravessaria, de maneira que este pudesse assisti-lo, caso necessário. Devemos nos recordar que Winnicott tomou similar atitude no caso de Margaret Little, entrando em contato com amigos de sua paciente, no caso, sem que ela soubesse, de forma que fosse possível prover egos-auxiliares fora do ambiente analítico. Bollas, por outro lado, nos deixa claro que essa atitude deveria ser tomada apenas pelo paciente, já que a comunicação do analista com um familiar do analisando representaria uma quebra no acordo de sigilo clínico.

A explicação da alteração do setting é percebida por Bollas como uma atitude crucial por parte do analista. $\mathrm{O}$ autor descreve então um exemplo de como comunicava ao paciente que o enquadre psicanalítico passaria por uma mudança:

Eu posso ver que você está passando por uma situação difícil e este é um momento importante para você. É minha prática padrão com todos os meus pacientes quando isso ocorre sugerir um aumento das sessões para nos dar tempo para processar o que está acontecendo. Então, caso você aceite, por enquanto eu gostaria que você viesse todos os dias no seu horário usual e novamente às 17:30. Para nos auxiliar neste período eu gostaria que você visse o Dr. Branch, um psiquiatra com quem eu trabalho, no caso de acharmos que você necessita de medicação ou qualquer outro auxílio médico. Eu gostaria que você o visitasse hoje ou amanhã, posso marcar a consulta para você. Você o verá uma vez por semana, ao menos durante as próximas semanas. Eu também gostaria que você visitasse seu clínico geral. (Bollas, 2013, p. 32)

Todas as articulações na citação anterior são meticulosamente colocadas por Bollas. O autor inicia o discurso mostrando ao paciente que seu sofrimento existe e é reconhecido pelo analista (algo que era fundamental também na prática de Ferenczi, Balint e Winnicott, como pudemos perceber ao longo desta tese). Ao 
destacar que se trata de uma prática padrão de parte do analista e que não é algo direcionado exclusivamente àquele paciente, Bollas coloca seu ato em uma esfera profissional, não pessoal, fazendo com que o paciente consiga relaxar e confiar no analista. $\mathrm{O}$ autor sugere ainda que, mesmo que o analista seja também um médico, é importante que se busque um outro profissional dessa área, de modo que uma pluralidade de visões contribua para o desenrolar do caso. Bollas sugere ainda o uso do motorista e define que o valor a ser pago pelo paciente não sofre alterações, explicando que o preço por ele praticado já prevê esse tipo de situação. Desse modo, a ansiedade causada pela impossibilidade de se pagar pelas sessões adicionais é evitada.

A principal preocupação de Bollas, ao formular essa explanação, é a de organizar um ambiente acolhedor (a nível de holding), que possa sustentar o paciente quando o colapso ocorrer. A própria forma da explicação transparece a formação literária do autor: “A explicação funciona como uma estrutura narrativa que provê um ambiente temporário acolhedor e prepara o analisando para o que está por vir" (Bollas, 2013, p. 33). O maior erro que poderia ser cometido nessa situação, a seu ver, seria o de não criar esse ambiente acolhedor a tempo, o que geraria um agudo (e evitável) sofrimento ao paciente:

Como o paciente não foi acolhido, seu pânico irá aumentar e o evento histórico originário (ou as estruturas mentais organizadas na primeira infância) que está agora emergindo coincide com o mesmo tipo de falha, ou fratura egoica, que ocorreu na primeira infância. $\mathrm{O}$ trauma atual agora se torna uma afirmação de que a situação original - seja a internalização da loucura dos pais ou a própria resposta distorcida do self ao mundo - é a verdade. Quando isso se consolida, penso que não pode ser desfeito. (Bollas, 2013, pp. 33-34)

O fragmento acima nos revela ainda uma interessante visão de Bollas a respeito do trauma. O evento traumático que precipitaria então a quebra do self, vivido já em uma fase adulta, corresponderia então a um momento que se sobrepõe a um anterior - o trauma atual sobre o trauma infantil, como uma revivescência forçada do que já não havia sido elaborado.

Bollas relata alguns casos clínicos que envolvem situações de colapso ao longo de sua obra, dos quais selecionaremos dois que estão descritos em Catch them before they fall (2013). O primeiro é o de Emily, paciente por volta dos trinta anos que buscou análise por se considerar uma fraude em vias de ser descoberta, apesar 
de ter considerável reconhecimento em seu ambiente de trabalho, temendo que seus colegas descobrissem como era carente. Ao longo de um ano e meio de análise, com uma frequência semanal de cinco sessões, Emily relatou a seu analista histórias de sua infância - seus medos, as separações de seus pais e suas dificuldades na escola. Sempre com uma postura tímida, mantinha certo distanciamento do analista, o que foi discutido entre os dois. Então, certo dia, Emily contou que seu namorado a deixou - esvaziou o apartamento deixando apenas uma nota, que dizia que entraria em contato em algumas semanas. O término não foi inesperado, mas Bollas notou sinais de que Emily estava entrando em colapso - sofreu um acidente de carro, sua aparência estava ruim, como se não estivesse tomando banho (o analista perguntou se ela estava cuidando de si, ao que a paciente respondeu que não). Bollas sugeriu então que Emily parecia estar precisando de ajuda adicional e explicou a ela as mudanças que estaria propondo ao tratamento - o motorista, para leva-la às sessões; o tempo adicional de análise (durante três semanas, foram conduzidas sete sessões semanais de noventa minutos de duração); que entraria em contato com seu clínico geral; e sugeriu a visita de um assistente social à sua residência, o qual encontrou um cenário muito preocupante - não havia comida em casa, roupas sujas e bagunça por todo o lugar, e contas que não havia sido nem abertas. Bollas atribui grande valor ao trabalho desempenhado por esse assistente social que, junto com alguns colegas, organizou a situação prática de Emily, comprando-lhe comida e lavando suas roupas.

Após essas três semanas se passou um período de dois meses em que as sessões foram reduzidas a cinco por semana, conservando o período de noventa minutos. Após três meses, Emily emergiria enfim de seu colapso. A este respeito, Bollas salienta que "Um aspecto crucial do processo de transformação para pessoas em colapso é a aliança com as partes saudáveis do self do sujeito, já que essas serão o alicerce a partir do qual o novo self emergirá” (Bollas, 2013, p. 44). Durante todo esse período, Emily raramente precisou se ausentar do trabalho e o reconhecimento dessas porções do self que a mantiveram funcionando permitiu que a paciente fosse capaz de seguir em frente com sua vida.

No entanto, ainda que Bollas tivesse montado essa equipe que sustentasse Emily em seu colapso, o autor considera que demorou muito a agir e, tivesse ele 
percebido a real situação anteriormente (como descobriu a partir da intervenção do assistente social), poderia ter abreviado o sofrimento da paciente mais cedo. Pelo relato do autor, podemos perceber que este foi um dos primeiros casos em que se valeu dessa clínica modificada - tinha acabado de conhecer seu motorista, Edward, assim como o médico de Emily e a equipe de assistência social. Bollas, na qualidade de analista, não estava suficientemente apoiado (held) para ser capaz de prover o apoio necessitado por sua paciente.

O segundo caso aqui escolhido difere do anterior porque, ao contrário de Emily, que demonstrou um colapso gradual e sinalizado, a paciente desenvolveu um quadro totalmente inesperado. Durante muitos anos de análise com Bollas, Anna, uma mulher além dos quarenta anos, sempre se apresentou como alguém vibrante, animada e de grande sucesso no trabalho. Em uma quinta-feira, ao chegar para sua sessão (às 15:00), Bollas se deparou com uma pessoa totalmente diferente, consideravelmente desvitalizada. Após uma tentativa de negar que havia algo de errado, a paciente reconheceu que alguma coisa tinha acontecido, embora não devesse tê-la chateado tanto. A descrição do que se seguiu então é crucial, tanto para a compreensão do caso como do manejo conduzido por Bollas:

Enquanto Anna falava sua boca secou e eu peguei-lhe um copo de água, pousando-o próximo dela em uma mesinha. Ela bebeu de um só gole, tentou falar e congelou completamente. Durante os próximos dez minutos ela olhou para mim em silêncio. Continuou tentando falar, botando sua mão sobre a boca, olhando para o teto e apertando as mãos como se tentasse se forçar a falar. Eu disse que estava tudo bem, ela deveria ficar à vontade. Deixei a sala, enchi novamente seu copo com água e pus uma nota em minha porta externa dizendo que devido a circunstâncias não previstas eu não seria capaz de manter meus compromissos naquele dia. Eu sabia que Anna estava tendo um colapso. (Bollas, 2013, p. 47).

Antes de prosseguir com o relato do caso, devemos fazer um comentário acerca de um elemento que pode passar despercebido na citação acima: a água. Ao longo do caso de Anna, Bollas chama atenção ao uso que a paciente faz da água a forma com que ela a bebe, como se tentasse se confortar para falar de algo difícil; a maneira como Bollas lhe oferece água, enchendo seu copo ou deixando algumas garrafas à disposição da paciente. Como percebemos nos capítulos anteriores, a água possui um importante significado simbólico, sendo associada por Ferenczi (1924a/2011) e Balint (1968) a estados muito primitivos - as condições intrauterinas e os momentos iniciais do amor primário. Trata-se, portanto, de um 
importante personagem em cenários regressivos, como Bollas reconhece, ao destacar em uma nota de rodapé (2013, p. 53), que além de pacientes se desidratarem em situações de grande perturbação, a água é uma significativa provisão simbólica durante fases regressivas na análise.

Durante os minutos seguintes, em vão, Anna continuou tentando falar, o que lhe provocou grande ansiedade. Após quarenta minutos mencionou que precisava ir, o tempo de sua sessão estava terminando, ao que Bollas respondeu que havia deixado um bilhete informando que não atenderia seus outros pacientes daquele dia e a sessão continuaria até as 18:00. Anna tentou protestar, mas não teve forças, se deixando cair novamente no divã. Apenas após duas horas do início da sessão Anna foi capaz de falar, ainda que de uma forma percebida por Bollas como totalmente diferente da habitual - uma fala lenta, em uma voz baixa e grave, com uma calma enganosa. Segundo a paciente, uma amiga de muitos anos a chamou de "vadia egoísta" (self-centered bitch) e que não sabia se queria continuar seu relacionamento com ela. A paciente relatou então que isso foi inacreditável para ela, que se apoiava imensamente no amor das pessoas.

Bollas nos diz que é fundamental a compreensão do evento traumático à luz do contex to daquele paciente, entendendo a linha de conflito ao longo da história daquela pessoa. $\mathrm{O}$ analista deveria, então, explicar ao paciente o que aconteceu e porquê da forma mais clara possível. A interpretação de Bollas a Anna nesse momento foi a seguinte:

\footnotetext{
'Por toda sua vida você teve que acreditar que era perfeita e amada por todos, porque se você não fosse maravilhosa sentiria que não era nada. Ao odiar sua mãe como odiou você se resgatou ao idealizar seu pai. Ele a idealizou, e na adolescência você pôde sentir que era uma pessoa maravilhosa. Você precisava sê-lo, de forma que escondesse a sua parte de você mesma que poderia odiar alguém tão violentamente que lhe faria perder seu sentido de si'. (Bollas, 2013, p. 48)

$\mathrm{O}$ autor considera que o primeiro passo para o estabelecimento de um ambiente adequado é a dimensão acolhedora da interpretação - parte do holding psicanalítico. Essa atitude é expressa pelo analista que compreende, não só por sua atitude empática, tal como queria Ferenczi ao "sentir com", mas pelo entendimento que tem da razão pela qual o paciente está passando por aquela situação. Foi essa a intenção de Bollas com a interpretação acima. Ao discutir se o analista deve dizer
} 
que o paciente ficará bem, ele entende que isso somente deve ser feito se o analista de fato acredita que o paciente ficará bem, o que deve basear-se em sua compreensão profissional e intelectual sobre aquele paciente, e não em mera intuição:

Não podemos fazer previsões quanto ao futuro de qualquer paciente baseado em conjecturas ou probabilidades. Quando falamos com nossos analisandos somos obrigados a falar a verdade, e se em algumas vezes seguramos um comentários, talvez cometendo, portanto, uma inverdade por omissão, isso deve ser feito pelos interesses do tato, não da mentira. (Bollas, 2013, p. 49)

Dessa vez, a confiança que Bollas sentia no que estava propondo a sua paciente - quanto à reorganização do setting e à participação da equipe - permitiu que Anna tivesse uma segurança equivalente, de forma que o pânico fosse arrefecido. $\mathrm{O}$ analista sugeriu então atendê-la no dia seguinte das 9:00 às 18:00 e que ela deveria ir a uma consulta com o Dr. Branch (o mesmo médico do caso anterior) naquela mesma noite. Embora o tempo da sessão fosse consideravelmente estendido, Bollas ressalta a importância de que esse período de tempo seja limitado - se dissesse que ela ficaria por lá até estar pronta para ir embora, isso poderia causar mais pânico, já que a paciente ficaria entregue ao seu próprio funcionamento egoico já prejudicado. Além disso, esse período de tempo tinha um significado importante para o analista: se Anna não fosse capaz de ir embora às 18:00, isso significaria que sua análise durante o colapso seria impossível, exigindo sua internação. Como nos diz o autor, esse novo enquadre seria também o símbolo do limite de sua abordagem.

Quanto à sugestão de Bollas, Anna recebeu a princípio com resistência. Teria um compromisso profissional e não queria perdê-lo. Bollas insistiu e, após um segundo protesto de sua paciente, disse-lhe que ela não estava em condições de comparecer a esse compromisso, que o mundo resistiria a dois dias sem ela. De acordo com o autor, a negociação desse novo contrato, bem como o reconhecimento das resistências que surgem dessa negociação, são fundamentais para o andamento do processo. Tendo Anna enfim aceitado a nova proposta, o analista sugeriu então que ela entrasse em contato com uma amiga para que ficasse de olho nela (a pessoa escolhida foi uma vizinha que sabia de sua análise). Após o fim da sessão, Edward, o motorista, levou-a a consulta com o Dr. Branch, que confirmou a Bollas que se tratava de um colapso depressivo. 
No dia seguinte, quando retornou para a sessão que duraria o dia todo, Anna teve dificuldades para começar a falar, até que disse subitamente "Certo!" e começou a explicar a conversa com sua amiga. Após Anna chorar por alguns instantes, $\mathrm{o}$ analista fez uma interpretação em um sentido que a paciente poderia ser difícil de ser alcançada, principalmente quando as coisas não vão bem. Após uma explosão hostil, Anna parou para refletir e começou a explorar o significado dessa interpretação junto com Bollas, que sugeriu que ela poderia ser falsa - uma faceta irreal de força, extroversão e saúde que esconde algo. A paciente passou os próximos minutos chorando até o momento da pausa para o almoço (combinada previamente). $\mathrm{O}$ autor destaca a importância desses intervalos - Anna iria a uma lanchonete próxima para comprar um sanduíche e essa mudança de local poderia trazer uma nova perspectiva. Quando retornou, passou uma hora sem nada dizer, mas parecia menos deprimida e mais reflexiva aos olhos de Bollas. Após discutirem mais alguns tópicos - a dificuldade de Anna em relacionamentos, sua mãe, sua infância e juventude - Edward a levou para casa quando a sessão terminou. Bollas considera que a sessão correu bem - Anna percebeu que estava desintegrada e um novo self deveria emergir de onde o outro havia se despedaçado: "Ou, colocando de outra forma, o falso self derivado das defesas contra seu ódio infantil dirigido à sua mãe colapsou e outra coisa, mais verdadeira para si mesma, estava agora emergindo" (Bollas, 2013, p. 55).

No dia seguinte, um domingo, Anna chegou ao consultório dizendo que havia se defecado durante a noite. Ao acordar e se dar conta da situação, tomou banho e lavou os lençóis. Bollas pontuou que ela havia cuidado de si e que aquilo que ocorrera foi um bom sinal, afirmando: "Você tem tido autocontrole demais, mantendo toda sua merda dentro. Então você teve um bom descanso, estava calma e era livre o bastante para deixar alguma merda sair" (Bollas, 2013, p. 57). Após um momento de incredulidade da parte da paciente, Anna e Bollas puderam rir da situação, permanecendo então em reflexão por alguns instantes. Depois de um tempo de silêncio, Anna disse que entendia que não poderia enganar as pessoas transparecendo a imagem daquilo que, de fato, não é. Perguntou então ao analista se, como ela já tinha alcançado aquela compreensão, poderia ir embora naquele momento. Percebendo a atitude de fuga como uma tentativa de defesa, Bollas 
explicou a Anna que ela estava usando a sua atividade mental de maneira que evitasse a experiência emocional contida no insight que ela havia tido:

Acho que você está tentando sair dessa sala tão rápido quanto puder. Com o primeiro sinal de recuperação, o que acredito que está acontecendo, você vai fugir daqui da mesma forma que fugiu da sua família; escapando antes que você realmente tenha que atravessar o processo de elaborar a merda que está em sua mente, em sua família. (Bollas, 2013, p. 58)

Um silêncio de uma hora se sucedeu. O autor diz que, embora seja difícil transcrever em palavras o que aconteceu, uma experiência bastante transformadora teve lugar, a partir do confronto do analista à tentativa de fuga da paciente por uma via intelectual.

Depois desses dias, Anna conseguiu se recuperar de seu colapso, mantendo seis sessões semanais durante quinze dias, retomando suas sessões usuais após isso. Bollas considera que o colapso de Anna era inevitável, tendo sido adiado por sua grande força (ou, poderíamos dizer, pela sólida adaptação de seu falso self). Ao atravessar esse momento em análise, Anna pôde conquistar um grande conhecimento sobre si, o que inclui uma importante elaboração sobre o trauma tanto o do passado, erigido pelas difíceis relações com sua mãe, quanto o do presente, disparado pela fala de sua amiga. Segundo o autor: "O aprendizado que acontece durante o colapso do self é um aprendizado profundamente emocional. Ele é pensado saturado na verdade do self, e minha experiência é de que enquanto o psicanalista continuar com a pessoa durante essa transição, ela funcionará” (Bollas, 2013, p. 59).

Notamos, então, a partir da descrição de Bollas desses casos que o autor sugere uma forma tão inovadora quanto transgressora e controversa para a clínica do trauma. Assim como Ferenczi fizera tantos anos antes, Bollas se lança para experiências clínicas com uma grande preocupação em mente: o alívio do sofrimento de seu paciente. No entanto, devemos destacar a afirmação do autor (2013), segundo a qual sua proposta envolve uma alteração no enquadre psicanalítico e não no processo em si; trata-se de uma nova estrutura temporária, extraordinária, que tenta lidar com situações extraordinárias. O suporte ao colapso do paciente levanta interessantes questionamentos para a clínica contemporânea, 
enquanto nos deparamos com tantos casos de síndrome do pânico e depressões severas - tantos pacientes à beira de um colapso.

Cabe questionar, por outro lado, o impacto das alterações na frequência ou duração dessas sessões na relação entre analista e paciente. A partir dos relatos do autor, podemos perceber que se trata de situações de intensidade emocional ímpar, o que, decerto, refletirá nos afetos envolvidos. Bollas não comenta a respeito da problemática contratransferencial nesse contexto, o que deveria suscitar alguma discussão. Ao relatar o caso de Anna, o autor nos informa que deveria fazer uma viagem de Londres a Nova York para um período de conferências - compromisso que precisou ser cancelado para que realizasse as sessões de dia inteiro ao longo do fim de semana. Embora o grupo que organizava essa viagem fosse bastante compreensivo, demonstrando interesse no progresso da paciente e entendendo que Bollas se dispunha a fazer esse tipo de trabalho, cabe questionar o tipo de sentimento hostil inconsciente que poderia surgir nessa situação, afinal o analista abre mão de muitas coisas para conduzir esses atendimentos - seu tempo pessoal e seus compromissos com outros pacientes, por exemplo.

Outra incerteza quanto a essa aplicação se refere às condições nas quais esses pacientes poderiam atravessar essas sessões. Bollas comenta que, ao descrever os selves partidos, pacientes aos quais destina a psicanálise do colapso, não está se referindo a indivíduos psicóticos, mas a pessoas normais que passam por um período de grande desorientação - de fato, fases regressivas permeadas por angústias de desintegração. Certamente, a aplicação dessas técnicas deve ser criteriosa, havendo a confiança do analista de que o paciente pode suportar essa nova temporalidade. Ainda assim, devemos considerar a possível intrusão em que pode incorrer essa presença externa tão constante do analista, sem que se considere sua possível introjeção.

Conforme sabemos, Winnicott já trabalhava assim em seus casos mais difíceis - quando Margaret Little precisou passar um tempo acamada, sem sair de casa, o inglês a atendeu domiciliarmente em sessões diárias de noventa minutos. Mesmo durante a análise usual ele mantinha uma certa flexibilidade no setting, de forma a proporcionar uma melhor adaptação a seu paciente sempre que possível. A crítica de Bollas (2013) a Winnicott, no entanto, é que este foi por demais 
conservador em sua atitude, o que teria causado em seus pacientes altos níveis de dependência em relação ao analista, o que frequentemente interferia em suas vidas por um tempo desnecessariamente longo. Embora não mencione essa ideia ao longo de seu trabalho, podemos inferir que Bollas demonstra certa preocupação relativa às formas benigna e maligna da regressão que Balint (1968) descrevera, tema abordado no capítulo anterior desta tese. É possível entender que a regressão dos pacientes de Winnicott, ao ver de Bollas, teria passado por fases malignas, em que a tendência regressiva à repetição não encontrava possibilidade de elaboração no limite inadequado que era disposto, prolongando o sofrimento e a análise além do necessário. Ao passo que sua proposta de ampliação do setting ofereceria um ambiente mais adequado para um novo começo no contexto da regressão benigna. Se essa ideia procede, de fato, é um tema que pode ser submetido a intermináveis questionamentos.

A proposta de Bollas encontra ainda outro obstáculo, considerando nosso contexto atual. Devido a diversos fatores - disponibilidade de tempo de parte do paciente, bem como seu alcance financeiro - estamos habituados a lidar muitas vezes com um regime de apenas uma sessão semanal; são poucos os pacientes que aceitam ou tem possibilidades de ir à análise duas vezes por semana ou mais. Bollas (2013) destaca que a Inglaterra tem uma flexibilidade maior do que os Estados Unidos quanto à necessidade do paciente ausentar-se do trabalho ou sair um pouco mais cedo para compromissos pessoais, o que lhe permite realizar esse tipo de atendimento enquanto o paciente mantém sua vida profissional em andamento. Nos casos relatados, Emily teve autorização para se ausentar do trabalho em alguns horários e Anna precisou perder uma importante reunião sem grandes prejuízos. No Brasil essa possibilidade existe, mas é difícil imaginar que seja possível, em qualquer nível profissional, manter uma continuidade desse tipo de atendimento sem que o paciente seja prejudicado em seu ambiente de trabalho por suas ausências. Sua sugestão, de no mínimo cinco sessões semanais, podendo ser ampliadas para dez ou até mesmo catorze parece, ao menos a princípio, um tanto utópica para a nossa realidade. É possível acreditar, no entanto, que alguma adesão poderia ocorrer, sendo importante em alguns casos. 
De qualquer forma, devemos sublinhar a corajosa contribuição de Bollas. Suas recomendações encontraram grandes resistências (as quais já lhe eram previsíveis) no meio psicanalítico, mas trouxeram uma nova perspectiva a uma problemática deveras atual. Ademais, Bollas nos ofereceu uma grande renovação no campo da clínica do trauma a partir de uma profunda reflexão sobre o papel do setting na afirmação de um ambiente acolhedor que, como sugere o título do livro, segure o paciente antes que ele caia.

\subsection{Thomas Ogden - Rêverie, interpretação e o terceiro analítico}

Thomas Ogden, nascido em 1946, é psiquiatra e psicanalista, norteamericano como Bollas, mas que desenvolve sua prática em San Francisco, California. Embora tenha feito formação psicanalítica no San Francisco Psychoanalytic Institute, logo mudou-se para Londres para distanciar-se da forte influência da psicologia do ego de Hartmann nos Estados Unidos. Continuou assim seus estudos na Tavistock Clinic, entrando em profundo contato com as obras de autores da psicanálise inglesa, como Klein, Bion, Tustin, Fairbairn, Balint e, principalmente, Winnicott.

É possível notar ao longo da obra de Ogden a pluralidade de influências com que o autor se defrontou, bem como seu esforço em condensar tantas ideias de forma a desenvolver uma clínica bastante original. O estilo poético da escrita de Ogden remete frequentemente à de Winnicott - da mesma forma que é possível perceber como as propostas do psicanalista britânico fundamentam a prática de Ogden. Embora as contribuições de Frances Tustin a partir de seu trabalho com crianças autistas estejam bastante presentes na obra de Ogden, bem como a base teórica kleiniana na qual se apóia, podemos perceber um pano de fundo winnicottiano que reside sob uma das mais importantes contribuições do autor, sua visão sobre a posição autista-contígua. Vejamos então suas principais características, dada a sua importância para as questões do trauma e da regressão.

\subsubsection{A posição autista-contígua}

Para o autor, esta posição representaria a mais primitiva das posições, considerando as posições esquizo-paranoide e depressiva de Klein. Ogden (1989) 
destaca, no entanto, que ela coexiste dialeticamente com as posições posteriores desde o princípio da vida psíquica. Sobre o nome que sugere para esta primitiva organização da experiência, Ogden nos explica que acredita que as formas patológicas de autismo se desenvolvem como versões hipertrofiadas das defesas da posição autista-contígua, evocadas por uma situação de extrema ansiedade infantil, embora não pense que o sistema fechado característico do autismo represente essa posição. Já sobre o termo "contígua", Ogden considera que ele remete à experiência de um contato corrente entre superfícies, a qual se constitui como o principal meio para que se façam as conexões necessárias à organização das experiências nesse contexto. Segundo o autor, “A palavra contígua oferece a necessária antítese para as conotações de isolamento e desligamento carregadas pela palavra autista" (Ogden, 1989, p. 50, grifado no original).

Quanto às experiências da posição autista-contígua, Ogden considera que elas ocorrem predominantemente em um nível sensorial (principalmente através o sentido do tato). $\mathrm{O}$ autor salienta o papel do objeto nessa situação:

[...] relações objetais são experienciadas - em um modo autista-contíguo - em termos de superfícies sensoriais geradas pelas interações do indivíduo com seus objetos e pelas transformações sensoriais ocorrendo dentro do indivíduo durante o curso dessas interações (Bollas, 1979). Ao objeto (uma impressão sensorial) se atribui significado e se responde a ele de maneira organizada e organizadora, de forma que envolva um interjogo mutuamente transformador de self (nascente) e objeto. (Ogden, 1989, p. 51)

Devemos sublinhar que Ogden cita, no fragmento acima, a noção de Bollas a respeito do objeto transformacional, como apresentado no princípio deste capítulo, o que explicita a importância que o autor atribui ao ambiente nos processos de desenvolvimento do sujeito. $\mathrm{O}$ tipo de cuidado que o ambiente oferece à criança nesse momento pouco tem a ver com qualquer tipo de experiência verbal, remetendo principalmente à dimensão sensorial e à qualidade da relação estabelecida no nível da presença do ambiente. Como nos diz Ogden:

Em um modo autista-contíguo, são as experiências de sensação, particularmente na superfície da pele, o principal meio para a criação da significação psicológica e os rudimentos da experiência do self. Contiguidade sensória da superfície da pele, junto com o elemento de rítmica, são básicos para o mais fundamental conjunto de relações objetais infantis: a experiência da criança em ser segurada, cuidada pela mãe e quando esta fala com ela. Essas experiências primitivas são objetais em um sentido específico da palavra que é relacionada à natureza da subjetividade na posição autista-contígua. (Ogden, 1989, p. 52) 
Percebemos, assim, que a posição autista-contígua de Ogden tem muito a ver com o que Winnicott diz ocorrer durante o desenvolvimento emocional primitivo - especialmente os processos de integração -, perpassando o caminho entre os níveis de dependência absoluta até a dependência relativa. Da mesma forma, devemos lembrar que Winnicott sugere que nos momentos iniciais da vida psíquica, todo cuidado físico é também um cuidado emocional e a manipulação da superfície epitelial possui grande importância no âmbito da personalização. Segundo Ogden, o conjunto das experiências sensoriais, com o tempo, gera a noção de um espaço limitado, uma superfície sensorial onde as experiências ocorrem - ou, diria Winnicott, o espaço que o psiquismo habita. Ogden oferece algumas amostras dessas experiências:

Exemplos de delimitação gerada pelos relacionamentos de contiguidade incluem a ideia de forma criada pela impressão da superfície da pele da criança quando repousa sua bochecha contra o seio da mãe; a noção de continuidade e previsibilidade da forma derivada da rítmica e regularidade da atividade de sugar da criança (no contexto de um ambiente acolhedor provido pela mãe); o ritmo do 'diálogo' meigo que a mãe e a criança desenvolvem; o sentimento de agudeza gerado pela criança ao pressionar suas gengivas firmemente no mamilo ou dedo da mãe. (Ogden, 1989, p. 53)

As vivências da posição autista-contígua ocorrem, portanto, em um contexto no qual mãe e bebê são indissociáveis - a subjetividade do bebê está sendo, portanto, sustentada pelo aspecto da díade mãe-bebê que reconhecemos, na qualidade de observadores externos, como a mãe. De acordo com Ogden:

[...] a criança e a mãe nunca são absolutamente únicos, e a subjetividade da criança na posição autista-contígua pode ser pensada como uma noção extremamente sutil, não autorreflexiva, de "continuar a ser" (Winnicott, 1956) na qual a necessidade sensorial está no processo de adquirir traços de desejo subjetivo (os princípios em um nível sensorial de um sujeito que deseja algo). A experiência sensorial em um modo autista-contíguo tem uma qualidade de rítmica que está se tornando continuidade de ser; tem a delimitação que é o começo da experiência de um lugar onde alguém sente, pensa e vive; tem as características de forma, solidez, frio, calor e textura, que são os princípios das qualidade de quem é o sujeito. (Ogden, 1989, p. 54)

É a partir das experiências sensoriais primitivas do contexto autistacontíguo, portanto, que emergirá algo como o sujeito. São elas ainda, segundo o autor (1989) que conduzirão a uma tolerância da separação entre a mãe e o bebê, responsabilizando-se então pelo desenvolvimento e delimitação entre o mundo interno e o mundo externo: “A elaboração normal da organização autista-contígua 
depende da capacidade da mãe e da criança para gerar formas de experiência sensorial que "curem" ou "tornem suportável" a consciência da separação que é um componente intrínseco da experiência infantil inicial” (Ogden, 1989, p. 52). Quando esta organização fracassa, se desenvolveriam então os estados patológicos do autismo infantil. No entanto, o autor nos recorda que essa defesa pode ocorrer também na vida adulta, em pacientes que já haviam adquirido alguma estrutura predominantemente neurótica, o que indicaria um padrão regressivo.

A noção da posição autista-contígua trouxe um importante desdobramento para a clínica de Ogden, como nos fica claro em seu relato sobre o caso de Robert, um jovem de dezenove anos que se encontrava internado em um hospital de orientação analítica quando Ogden começou a atendê-lo. Além de esquizofrênico, o rapaz era portador de uma doença degenerativa congênita da retina, que havia sido diagnosticada tardiamente, o que representaria o fracasso do cuidado materno na falta de sua capacidade de perceber e responder à criança - embora Robert já apresentasse dificuldades na visão desde os três anos, apenas quando um amigo da família notou este problema é que Robert foi submetido a um exame para diagnóstico, já aos cinco anos de idade. Aos dezesseis anos, Robert já teria perdido grande parte de sua visão, sendo capaz de ver apenas sombras de grandes objetos, sem que lhe fosse possível distinguir cores.

O relacionamento da mãe com Robert é descrito por Ogden (1982) como amplamente irregular, alternando momentos em que ela se dedicava intensamente a ele, seguido por períodos de profundo retraimento e ódio, a mesma atitude que a mãe tinha em qualquer tipo de atividade em sua vida (como, por exemplo, aulas de dança). O bebê era deixado pela mãe em seu berço por horas, até que ele começava a embalar o berço e a bater com a cabeça em uma barra de madeira, segundo o relato da mãe, sem demonstrar dor. Os relacionamentos amorosos nos quais sua mãe se lançou foram igualmente fugazes, normalmente terminando com seu parceiro ou parceira se distanciando devido à falta de correspondência afetiva de parte da mãe de Robert.

Aos nove anos, o paciente começou a experienciar alucinações de que aranhas o invadiam pela garganta e o sufocavam, embora não as revelasse a ninguém. Após um período de dez anos perambulando com a mãe pelas casas de 
amigos dela, sem uma residência fixa, o pai de Robert, que havia se separado da família quando o paciente ainda era criança, reapareceu e levou o rapaz para morar com ele. Sua mãe, já cheia de cuidar do rapaz, prontamente aceitou, permanecendo três anos sem qualquer tipo de contato com ele. Logo após mudar-se com o pai, aos dezenove anos, essas alucinações se intensificariam, levando seu pai a hospitalizálo.

Robert foi submetido então a uma análise de cinco sessões semanais com Ogden. O paciente demonstrava uma atitude retraída perante o analista, falando poucas palavras e rolando seus olhos para cima, de forma que apenas a esclera permanecesse visível - olhos voltados para o mundo interno, portanto. Uma fase de não experiência tomou lugar, durante a qual o paciente demonstrou pouca atividade mental e uma distante relação com o terapeuta. Embora Ogden ofereça uma discussão mais ampla do caso de Robert em seu livro Projective identification and psychoanalytic technique, de 1982, principalmente sobre essa fase de não experiência, nos ateremos ao recorte definido posteriormente, em Primitive edge of experience, de 1989, devido a precisa explanação do autor a respeito de seu método para lidar com experiências de uma angústia tão primitiva.

Durante a segunda fase da análise de Robert, que sucedeu esse período inicial de não experiência, Ogden (1989) relata que Robert se recusava a tomar banho, independentemente da estratégia de barganha ou intimidação de que se valia a equipe de enfermagem - o paciente ainda estava hospitalizado, nesse momento. Não costumava trocar de roupa para dormir e seu cabelo era um emaranhado oleoso. Devido à sua falta de higiene, Robert desenvolveu um intenso mau cheiro, que permaneceria na sala de Ogden por horas mesmo depois que ele saísse. O autor relata então seus sentimentos de incômodo devido à invasão sensorial que sofria:

Ele se encostaria na cadeira macia de meu consultório com seu cabelo oleoso na parte de madeira do encosto da cadeira. $\mathrm{O}$ aspecto da interação da transferênciacontratransferência que eu estava mais consciente no momento era o da forma com que eu me sentia invadido por esse paciente. Quando ele deixava meu consultório, eu não conseguia sentir que tinha um descanso dele. Eu sentia como se ele tivesse conseguido, de forma literal, entrar em mim - ficar debaixo da minha pele - através de seu odor que saturava minha mobília (com a qual eu havia ficado intimamente identificado). Eu eventualmente entendi esses sentimentos como minha resposta a (participação inconsciente em) uma identificação projetiva na qual o paciente estava engendrando em mim seus próprios 
sentimentos de ser dolorosamente e involuntariamente infiltrado por seu objeto interno mãe. (Ogden, 1989, p. 57)

Ao ser questionado sobre o que tanto o assustava quanto ao banho, o paciente respondeu a Ogden que era por causa do ralo. O analista entendeu, então, que a grande angústia de Robert era relativa a se dissolver e literalmente correr ralo abaixo. Ogden (1989) nos oferece alguns exemplos de manifestações de ansiedades relativas à posição autista-contígua, entre elas a sensação de estar apodrecendo, de que seus fluidos corporais estão vazando, de estar caindo e o medo de cair em um espaço infinito e sem forma ao dormir - angústias, portanto, muito primitivas, em uma dimensão sensório-corporal, da mesma forma que aquela sentida então por Robert. O intenso cheiro do paciente consistia, então, em uma tentativa de se aterrar na realidade - cuja orientação para o sentido do olfato deveria ter sido provavelmente influenciada pela ausência do seu sentido da visão. O entendimento de Ogden dessa dinâmica é altamente ilustrativo:

Seu odor constituiu uma forma autística confortadora que o ajudou a criar um lugar no qual ele poderia sentir (através de suas sensações corpóreas) que ele existia. Seu tremor lhe deu uma elevada noção de sua pele; ao rolar seus olhos para dentro de seu crânio se isolou das sombras borradas e sem contorno que percebia visualmente. (Anos depois ele me diria que essas sombras eram 'piores do que não ver nada' porque o faziam sentir como se estivesse se afogando). (Ogden, 1989, p. 58)

A partir de um ponto de vista winnicottiano, podemos entender o quão primitivas eram as angústias de Robert. $\mathrm{O}$ medo de se dissolver e descer pelo ralo tem claramente um componente relativo à desintegração - o sujeito, que pouco conseguiu se integrar, provavelmente não teria qualquer apoio do ambiente para se manter uno. Seria impossível conservar alguma confiança em um ambiente tão irregular - ou estava presente em excesso (as fases em que sua mãe se superinvestia em seu cuidado, personificadas nas aranhas que o invadiam) ou simplesmente se tornava ausente. O odor de Robert e sua recusa em tomar banho fariam parte, então, da dinâmica transferencial, através do qual estabelecia uma relação objetal contígua através do uso de uma forma autística: "A perda de seu odor seria equivalente à perda de si. Seu odor provia os rudimentos de ser alguém (alguém com aquele cheiro particular), estar em algum lugar (um lugar em que poderia perceber seu odor), e ser algo para outra pessoa (alguém que pode cheirá-lo, ser impregnado por ele e lembrar-se dele)" (Odgen, 1989, p. 59). 
É interessante destacar que ao longo do relato de Ogden em ambos os trabalhos, consta pouca produção interpretativa. Por outro lado, o autor nos transparece um intenso trabalho sobre a dimensão contratransferencial, especialmente sobre a forma com que se sentia agredido e invadido pelo paciente na forma com que este tratava seu mobiliário, como podemos observar nos seus trágicos relatos de quando tentava lavar suas almofadas com diferentes produtos para remover o cheiro deixado por Robert. A elaboração da tensão enfrentada pelo analista nos momentos de silêncio foi igualmente importante - Ogden considerava que o paciente estava mais bem equipado do que o terapeuta para lidar com essas situações de silêncio, vivenciando-as sem demonstrar angústia. Um dos poucos vestígios interpretativos relatados por Ogden surgiu de um desses momentos de silêncio:

Durante uma dessas sessões, uma sirene barulhenta de uma ambulância ou viatura policial foi ouvida e o paciente, não inesperadamente, disse, "Uma sirene". Ele então riu e acrescentou, "Eles estão vindo para te pegar, te prender." Após uma longa pausa, ele adicionou, "Você está cercado." Este foi o primeiro momento de atividade fantasística verbalizada desde a sintomatologia psicótica inicial. O terapeuta sentiu um alívio momentâneo da pressão da luta interpessoal e disse, "Você quer dizer invadido, não é?" O paciente sorriu mas não respondeu. (Ogden, 1982, p. 195)

A meu ver, a interpretação de Ogden é precisa, mas possui um significado muito complexo, cuja base fundamentaria seus desenvolvimentos clínicos posteriores, como veremos mais adiante. Quando o analista sugeriu que Robert queria dizer "invadido", não estava referindo-se apenas à invasão que estava sofrendo pelo odor do paciente, mas também às invasões sofridas pelo paciente desde sua infância, o que estava sendo reproduzido em um novo nível. É curioso ainda pensar que essa intervenção da parte do analista se configurou em uma situação em que o setting estava sofrendo, de certa forma, uma invasão sonora de parte da sirene. Ogden considera que a emergência do material fantasístico de Robert lhe permitiu então, pela primeira vez, libertar-se da rigidez do campo das ideias, sentimentos e representações self-objeto nas quais estava operando: "Gradualmente, [...], o terapeuta tornou-se capaz de formular mais precisamente o significado do que estava transpirando entre ele mesmo e o paciente" (Ogden, 1982, p. 195). Trata-se, portanto, de uma intepretação que ultrapassa tanto a dimensão transferencial quanto a contratransferencial, relativa ao campo intersubjetivo construído no ambiente analítico a partir do estado regressivo do paciente à situação 
original do trauma - as invasões e as consequentes reações exigidas -, acompanhado pelo analista que se enveredou na mesma direção que o analisando. A respeito da relação transferencial/contratransferencial experienciada durante essa etapa, Ogden nos diz o seguinte:

Atuações transferenciais não verbais em conjunção com os estados associados contratransferenciais foram importantes fontes de informação para a formulação descrita. Em uma fase predominantemente não verbal da terapia, deve-se necessariamente contar muito com tal informação. Interações e comunicações em estágios posteriores da terapia, mais verbalmente simbólicos, fornecem dados que podem confirmar ou invalidar as formulações anteriores. (Ogden, 1982, p. 197)

Posteriormente, Ogden aprofundaria uma interessante discussão a respeito desses fenômenos a partir da formulação de uma proposta clínica de grande pluralidade de influências, devendo-se destacar, no entanto, os conceitos de Winnicott e Bion. Com o intuito de ampliar a técnica relativa a esse campo intersubjetivo, Ogden nos oferece uma de suas principais contribuições, o conceito do terceiro analítico.

\subsubsection{O terceiro analítico intersubjetivo e a rêverie}

Nos foi possível perceber, a partir do relato do caso de Robert, que seu trauma se constituiu de forma silenciosa em um momento primitivo. Sua mãe, que parece nunca ter se orientado no sentido de um ambiente suficientemente bom - era ou totalmente ausente ou presente em excesso - foi incapaz de atender às necessidades de Robert desde o início de sua vida psíquica. A forma com que o bebê batia com a cabeça no quadro de madeira do berço, enquanto a mãe assistia, demonstra as desesperadas tentativas de Robert em permanecer vivo, com algum tipo de contato com a realidade - tão concreta quanto a dura baliza de seu berço. Sobre esse tipo de defesa primitiva, Ogden nos explica: "Defesas geradas em um modo autista-contíguo são direcionadas ao restabelecimento da continuidade da superfície sensorial limitada e da rítmica ordenada sobre a qual a integridade inicial do self jaz" (Ogden, 1989, p. 70), ou seja, se trata da tentativa de criar uma espécie de piso sensorial através do uso de formas autísticas, que visam a estabelecer um estado de tranquilidade. Essas defesas podem ser observadas com clareza na clínica através de certos comportamentos do paciente, como mexer nos cabelos, nos lábios, nas bochechas e nos lóbulos das orelhas, ou ao mexer as pernas e bater com os pés 
no chão. Notamos, então, que são atitudes não verbais, justamente por pertencerem a uma dinâmica sensorial, pré-verbal e, portanto, pré-edípica.

A angústia de Robert, no momento da terapia descrito por Ogden (1989), possuía natureza notavelmente primitiva. Ao recordar as ansiedades da posição autista-contígua descritas pelo autor, as quais abordamos anteriormente, podemos reconhecer claramente a manifestação de Robert quanto à ameaça de desintegração que se instaurou em um momento traumático da infância. Percebemos que sua mãe foi incapaz de reconhecê-lo enquanto sujeito. Na ausência, deixava de servir como ego auxiliar, relegando Robert à solidão (o que é completamente diferente da noção de Winnicott (1958/1983) da capacidade de estar só, que ocorre justamente na presença do outro) e à ameaça de aniquilação. Enquanto presente, o invadia com uma maternagem aparentemente estereotipada - Ogden (1982) nos diz que ela ocasionalmente se investia em uma posição de mãe modelo: "Em suas palavras, ela [a mãe] 'se jogava no bebê', tentando antecipar cada desejo dele” (Ogden, 1982, p. 181). Percebemos, portanto, que o severo trauma vivido por Robert nos momentos iniciais de sua vida, conforme descrito por Ogden, possui muito em comum com a concepção winnicottiana do trauma relativo ao desenvolvimento emocional primitivo, conforme discutimos no capítulo anterior. Podemos entender, no entanto, que o falso self construído pelo paciente - uma defesa vivenciada corporalmente a partir da camada de sujeira e do odor que envolviam seu corpo - não foi bem sucedido, uma vez que o núcleo de si permanecia exposto a possíveis ataques. Diante da imprevisibilidade do ambiente e da falta de adaptação demonstrada pelo mesmo, a conquista de algum nível de integração se mostrara uma difícil tarefa, mantendo sempre presente a possibilidade de perda do pouco desenvolvimento que havia sido alcançado.

No caso de Robert, no entanto, essa ameaça parecia ser demasiadamente vívida. Não, não era uma simples ameaça, havia praticamente uma certeza de que ele de fato se desintegraria ao se banhar - a água do chuveiro desconstruiria a única defesa à qual Robert se via capaz de conduzir, seu débil falso self. A ausência de um cuidado suficientemente bom em termos de holding por parte de sua mãe impediu que a desintegração se constituísse apenas como ameaça, sendo vivenciada sua iminência de forma simultânea, no passado, presente e futuro. Ogden (1989) 
nos descreve ainda um outro caso que expõe a visão do autor acerca da reprodução do trauma na relação analítica. A Srta. K, uma universitária de 25 anos, iniciou um processo terapêutico devido ao pânico que sentia em relação à neblina e ao som do oceano, um pavor de tal intensidade que a levava a temer enlouquecer, perdendo contato com a realidade. Ogden relata então que a Srta. K, aos quatro meses de idade, perdeu a convivência com a mãe, que havia sido hospitalizada ao longo de catorze meses devido a uma meningite espinal. Quando voltou para casa, a mãe da paciente passou a controlar tiranicamente a casa a partir da cadeira de rodas metálica à qual estava presa. O autor descreve então uma memória da Srta. K., que a entende como sua mais antiga lembrança:

A memória mais inicial da paciente (que lhe parecia tanto um sonho quanto uma memória) era de ser afastada pela sua mãe ao tentar encostar nela, que repousava em sua cadeira de rodas. Ao mesmo tempo, a paciente nessa lembrança, olhou pela janela e viu uma garotinha caindo através do gelo no lago que se localizava logo atrás da casa da paciente. A Sra. K. disse à sua filha, 'É melhor você salvála'. (Ogden, 1989, p. 69)

Ogden percebe então, a partir da memória da paciente, que esta era representada por ambas as crianças do relato: a que cai pelo gelo e a que deve salvar a que caiu antes que se afogue. Trata-se de cair atravessando a superfície delimitadora do self, que não resiste por não ter sido estabelecida de forma eficaz a partir da experiência de personalização que deveria ter sido proporcionada pelo ambiente suficientemente bom. Ao mesmo tempo, a mãe se mostra incapaz de ajudar, relegando o destino da menina a ela mesma. Por outro lado, o medo do som do oceano e da neblina são experienciados pela paciente como a ameaça do espaço sem forma no qual ela poderia cair se atravessasse a camada de gelo. Nesse caso, o trauma da Srta. K nos mostra um paralelo em relação ao de Robert - trata-se de uma ameaça de desintegração sem que haja alguém que possa ajuda-la. Uma agonia a esse nível - impensável, nos diria Winnicott - não teria possibilidade de elaboração a um nível verbal. Deveria ser construída a partir da relação terapêutica regressiva e, principalmente, do produto dessa relação.

Essa questão perpassa a visão de Ogden a respeito da interpretação. De acordo com o autor, a ação interpretativa corresponde a uma comunicação da parte do analista para o paciente de um aspecto da dinâmica transferencialcontratransferencial, podendo ocorrer de forma verbal ou não. Segundo Ogden: 
Às vezes tal atividade está desconectada das palavras (por exemplo, a expressão facial do analista enquanto o paciente se demora na porta do consultório); às vezes a atividade do analista (enquanto meio para interpretação) toma a forma de 'ação verbal', por exemplo, ao estabelecer o preço, o anúncio do término da sessão ou a insistência de que o analisando pare com alguma forma de atuação; às vezes a ação interpretativa envolve a voz, mas não palavras (por exemplo, a gargalhada do analista). (Ogden, 1994, p. 108)

Percebemos, assim, que Ogden ultrapassa a noção de interpretação (à qual comumente se atribui uma qualidade verbal) de grande parte dos autores da psicanálise. Winnicott, em Holding e interpretação (1972), já sugeria uma abordagem similar, ao propor o uso da interpretação como meio para a integração de experiências ocorridas no setting e no ambiente externo. Essa ideia pode ser ilustrada a partir da intervenção de Ogden destacada anteriormente, quando um momento de silêncio é cortado pelo grito de uma sirene na rua e Robert diz que eles iriam pegar o analista, que ele estava cercado, ao que Ogden sugere que o paciente queria, na verdade, dizer invadido.

Podemos identificar na interpretação de Ogden, além de sua essência integradora, que proporcionaria um significativo avanço terapêutico tanto para o paciente quanto para o analista, uma grande complexidade. $\mathrm{O}$ sujeito que estava sendo ali invadido não era apenas o analista, que sofria com o odor de Robert. Também não era o paciente, que tantas invasões sofrera de parte de sua não amorosa mãe. A interpretação recaía, de fato, sobre um produto desses dois elementos, aquele que Ogden chamaria, alguns anos mais tarde (em Subjects of analysis, de 1994), de terceiro analítico.

Existem, na análise, duas pessoas - o analista e o paciente - com seus respectivos tempos. Há o tempo da associação livre do paciente e o tempo da atenção flutuante do analista. Entre essas partes, se desenvolve uma ponte que permite a comunicação entre ambos - no entanto, embora essa experiência seja cocriada, ela se desenvolve de forma assimétrica pelo par analítico, sendo privilegiada a exploração do mundo objetal interno do paciente, já que a relação analítica é desenvolvida de maneira a ajudá-lo. Assim, além do analista e do analisando, se desenvolve um terceiro analítico intersubjetivo, que permanece em uma tensão dialética com as partes como indivíduos separados, dotados de suas subjetividades próprias. Segundo Ogden, “Em resumo, o terceiro analítico não é um único evento experienciado identicamente por duas pessoas; pelo contrário, é uma coleção de 
experiências intersubjetivas inconscientes construída de forma conjunta, embora assimetricamente, no qual analista e analisando participam" (Ogden, 1997, p. 110). É importante salientar, portanto, que as dimensões intrapsíquicas do paciente e do analista não são ignoradas, mas trazidas para o jogo intersubjetivo.

Coelho Junior (2013) destaca também a importância da criação de um espaço que intermedia as duas partes no setting. De acordo com este comentador, "Thomas Ogden descreve esse meio como sendo o de conversas na fronteira do sonho (conversations at the frontier of dreaming). Trata-se simultaneamente, de uma conversa consciente e inconsciente, que se passa no interior da experiência psíquica de cada um dos participantes da análise e, também, entre os participantes" (Coelho Junior, 2013, p. 54). Essa fronteira corresponde ao lugar do sonhar, do brincar, onde nasce a criatividade - o espaço, portanto da rêverie.

O conceito de Ogden (1997) sobre a rêverie, embora inspirado na ideia elaborada por Bion (1962), corresponde à discussão das experiências do próprio autor ao tentar fazer uso dessa singular forma de comunicação no processo analítico. A definição que Ogden nos oferece de sua noção sobre a rêverie é a seguinte:

\footnotetext{
Vejo a rêverie como um evento simultaneamente pessoal/privado e intersubjetivo. Como é o caso com outras experiências emocionais altamente pessoais do analista, ele não costuma falar diretamente com o analisando sobre suas experiências, mas tenta falar com o analisando a partir do que está pensando e sentindo. Isto é, ele tenta informar o que diz pela sua consciência e fundamentação em sua experiência emocional com o paciente. (Ogden, 1997, pp. 158-159, grifado no original)
}

Coelho Junior considera que a rêverie corresponde, na análise, ao mesmo estado que experimentamos no sono pelo ato de sonhar, ou seja, a sonhos acordados por parte do analista. Este autor (2013) oferece como exemplo uma situação clínica, durante a qual um paciente lhe relatava um sonho em que estava na casa onde vivia quando tinha cerca de cinco anos, encontrando seus irmãos com a idade atual. O relato onírico do paciente fez com que o analista encontrasse uma correspondência em sua própria vida, construindo a imagem da casa em que ele havia vivido quando tinha a mesma idade que o paciente lhe falara. A interferência de seus devaneios fez com que intercedesse no discurso do paciente - essa situação foi vista pelo autor como um risco tomado de forma não calculada, podendo desviar a associação livre 
do paciente para a sua, mas que acabou por fundamentar uma oportunidade para a elaboração de um conteúdo que não havia sido antes mencionado, envolvendo a relação entre o paciente e seu pai. Como Ogden o fizera no caso de Robert, Coelho Junior acompanhou o processo regressivo de seu paciente:

Na situação clínica apresentada acima, o sonho foi o primeiro passo em direção à regressão, por meio do que o paciente foi capaz de lembrar algo de seu passado. Segui sua regressão com a minha própria regressão, que eu acredito ter ajudado a viabilizar algo novo como forma de elaboração e não apenas de repetição. (Coelho Junior, 2013, p. 57)

Assim, compreendemos o valor do uso da rêverie diante de pacientes regredidos, uma vez que ela nos permite a compreensão de algo primitivo, que não pode ser colocado em palavras pelo paciente. Podemos entender ainda que o exemplo sugerido por Coelho Junior acerca de sua rêverie corresponde, na realidade, a uma intervenção não calcada em sua experiência pessoal, mas na experiência compartilhada no espaço terapêutico - o terceiro analítico. Segundo Ogden:

\begin{abstract}
Paradoxalmente, por mais pessoais e privadas que as rêveries do analista lhe pareçam, é enganoso ver as rêveries do analista como 'suas' criações pessoais, já que a rêverie é, ao mesmo tempo, uma construção intersubjetiva inconsciente criada de forma conjunta (mas assimétrica) que eu denominei 'o terceiro analítico intersubjetivo'. Ao conceituar a rêverie tanto como um evento individual psíquico quanto como uma construção inconsciente intersubjetiva, estou contando com uma concepção dialética da interação analítica. $\mathrm{O}$ analista e o analisando, juntos, contribuem para e participam de uma intersubjetividade inconsciente. Parafraseando e expandindo Winnicott, não há tal coisa como um analisando separado do analista; ao mesmo tempo, analista e analisando são indivíduos separados, cada um com sua própria mente, corpo, história e daí por diante. (Ogden, 1997, pp. 159-160)
\end{abstract}

Ao evocar e alterar a célebre frase de Winnicott, já discutida anteriormente nesta tese, Ogden sugere o nível de fusão presente na relação intersubjetiva, ao mesmo tempo em que, paradoxalmente, analista e paciente mantém-se como sujeitos distintos. Essa influência winnicottiana é percebida ainda na forma com que Ogden percebe o espaço analítico como uma área para um jogo interpsíquico, na qual as subjetividades das duas partes se encontram e se sobrepõem para a criação de algo maior do que a soma das partes.

Podemos concluir, portanto, ressaltando a pertinência das contribuições de Ogden para a clínica do trauma, especialmente aquele de qualidade primitiva. Sua 
visão a respeito da ação interpretativa oferece um amplo conjunto de ferramentas para lidar com fenômenos regressivos e sofrimentos primitivos, a partir de uma possibilidade de interpretação que não precisa se comprometer com o material verbal presente (ou, no caso, ausente). A rêverie surge como uma possibilidade na criação do material intermediário, na qualidade do terceiro analítico, de forma que o analista seja capaz de acompanhar a regressão do paciente engajando-se na tarefa de elaboração conjunta do material primitivo não representado. A posição autistacontígua, por outro lado, oferece uma compreensão de muitos dos fenômenos relativos ao estágio que Winnicott chamaria de dependência absoluta, como já foi sugerido antes, mas podemos perceber também alguns pontos paralelos à linguagem da ternura, de Ferenczi - as experiências são brutas, sem necessidade ou possibilidade de representação, ao mesmo tempo em que o que está em jogo são as demandas amorosas, em nível de ternura, da parte da criança.

\subsection{Stefano Bolognini - o interpsíquico na clínica italiana}

Mesmo que a Sociedade Italiana de Psicanálise tenha sido fundada no longínquo ano de 1925 por Edoardo Weiss e Marco Levi-Bianchini (que recebiam o apoio de Freud), por muitos anos a psicanálise da Itália permaneceria em uma espécie de limbo. Como nos conta Di Chiara (2016), períodos difíceis foram atravessados, como a perseguição de Mussolini à psicanálise, em conjunção a Hitler, durante os anos 30 e 40; a primeira crise institucional, que levou a uma intervenção da IPA sobre aquela Sociedade (solicitada pelas "três princesas", Alessandra Tomasi di Palma, Marie Bonaparte e Anna Freud, no Congresso de Edinburgo, em 1961); e uma segunda crise, já no início dos anos 90, quando o então presidente da IPA, Joseph Sandler, nomeou uma comissão para investigar os problemas relativos ao método de indicação para candidatos à Sociedade e à má conduta ética de um membro. Em 1993, com o fim das investigações, Giuseppe Di Chiara assumiria como presidente da SPI, tendo início um rico período de produções psicanalíticas que levaria então a diversificada psicanálise italiana ao conhecimento de outros centros.

Diversos autores viriam a contribuir com essa expansão italiana, como Antonino Ferro, Stefano Bolognini, Vincenzo Bonaminio, Franco Borgogno, Roberto Tagliacozzo, Giuseppe Civitarese e Anna Maria Nicolò, além do próprio 
Di Chiara. Nos deteremos, no entanto, em um dos mais proeminentes psicanalistas da atualidade, Bolognini, devido à sua enriquecedora concepção a respeito dos fenômenos interpsíquicos tão presentes na clínica do trauma pela via do manejo dos fenômenos regressivos.

Natural de Bolonha, na Itália, Bolognini concluiria sua formação como psiquiatra em 1978. Tendo ingressado na Sociedade Italiana de Psicanálise em 1985, teve grande participação na sua evolução, atuando como secretário científico durante quatro anos e presidente da sociedade por outros quatro. $\mathrm{O}$ autor teve relevância inclusive em nível internacional, tornando-se presidente da IPA (International Psychoanalysis Association) na década de 2010.

Da mesma forma que Bollas e Ogden, Bolognini construiu uma formulação teórico-clínica sobre a base de diversos autores. Além de Freud, o italiano costuma se valer de muitas referências a psicanalistas como Klein, Ferenczi, Sandler, Schafer e Bion. No entanto, é notável que dois autores se destacam como influências para Bolognini: Kohut e Winnicott.

Sobre o primeiro, Bolognini se vale recorrentemente da forma com que Kohut explorou o conceito de rêverie, assim como Ogden. Essa ferramenta serve como base de grande parte das ideias de Bolognini a respeito da relação interpsíquica que se desenvolve no setting. Já quanto ao segundo, o italiano parece constituir grande parte de seu idioma clínico a partir dos conceitos de Winnicott, buscando estabelecer um ambiente adaptado de forma muito semelhante à do inglês, a partir de uma comunicação além da dimensão verbal que envolve o cuidado, lembrando muitas vezes o manejo da psicose de transferência descrito por Winnicott.

Uma das grandes contribuições de Bolognini à psicanálise é a exploração do conceito de empatia psicanalítica, tema de imensa relevância para a compreensão de fenômenos regressivos no ambiente analítico já que se apoia na comunicação não verbal e no reconhecimento dos estados internos do paciente como possibilidade de compreensão do trauma primitivo pelo qual passou o analisando. Essa forma peculiar de empatia é frequentemente confundida, segundo o próprio autor (2008/2009) com a empatia comum. Trata-se, em sua ótica, de uma habilidade 
muito mais complexa do que se pensa, com grandes repercussões para a elaboração de processos inconscientes e pré-conscientes (sejam eles verbais ou não), base da relação interpsíquica da análise a seu ver, como entenderemos a seguir.

\subsubsection{A empatia psicanalítica}

Bolognini nos relata que suas ideias sobre a empatia psicanalítica tiveram origem nos primeiros anos de sua prática, quando ainda era um jovem candidato na Sociedade Italiana de Psicanálise. Nesses momentos, o autor se deparava com uma “experiência intrassessão" rara, imprevisível e notável pelo intenso contato emocional e a decorrente clareza representacional que o conteúdo exposto pelo paciente adquiria. Essas situações, nos diz o autor (2008/2009), eram experienciadas e compartilhadas tanto pelo analista quanto pelo paciente juntos, mas ainda com uma sensação de que ambos existiam enquanto figuras separadas e definidas. Coexistiam então o olhar psicanalítico e um sentir expandido a áreas mais profundas da subjetividade. $\mathrm{O}$ autor sugere uma metáfora que ilustra essa situação:

Não encontro uma metáfora melhor que aquela que alude a certos dias charmosos quando o ar está límpido e a vista pode chegar longe, até o horizonte, sem impedimentos. De minha cidade se vê muito bem os Alpes quatro ou cinco vezes ao ano, quando uma feliz coincidência de correntes de ar limpa o panorama de nuvens, umidade, neblina, etc. (equivalentes simbólicos de nossas defesas internas e das dificuldades de 'engrenagem relacional' interpsíquica). Nestes raros dias a montanha nos aparece em toda sua comovedora beleza sem que as distâncias reais resultem desmentidas: elas estão e aparecem longe, portanto bem separadas de nós, mas também são claramente perceptíveis e desfrutáveis até nos mínimos detalhes, da paisagem gradual dos bosques às ladeiras subindo até as rochas iluminadas pelo sol. (Bolognini, 2008/2009, p. 160)

A imagem descrita por Bolognini reforça uma ideia que o autor havia expressado em um trabalho anterior, segundo a qual a empatia oferece ao analista uma posição privilegiada para sentir com o paciente, pensando nele e, frequentemente, juntamente a ele (Bolognini, 2002/2008). O autor complementa ainda:

Em tais ocasiões me impactava constatar como esta condição privilegiada permitia, em modo natural, trabalhar com o paciente sem particulares forçamentos (o ato de forçar), e mais, respeitando especificamente os ritmos e as dificuldades subjetivas, justamente porque também o medo, os obstáculos, os fechamentos do interlocutor eram objetos de adequada percepção e do conseguinte instintivo respeito. (Bolognini, 2008/2009, p. 160) 
Percebemos, então, que a empatia sugerida pelo autor abarca uma sintonização entre as partes - analista e paciente - de forma que ambos mantenham o trabalho analítico em um mesmo compasso. Envolve ainda o reconhecimento da constituição subjetiva do paciente, suas dificuldades e defesas. Poderemos notar, ao longo desta seção, que as ideias de Bolognini trazem muita originalidade para a clínica, mas não foram criadas a partir de uma página em branco pelo autor.

Em sua obra seminal, A empatia psicanalítica (2002/2008), o italiano descreve o percurso do conceito de empatia, enquanto construção interrelacional de aplicabilidade clínica, ao longo dos anos. Na seção denominada Os pioneiros, Bolognini se refere a alguns autores que considerava desbravadores da ideia de empatia após as primeiras formulações freudianas, destacando, além de Helene Deutsch e Robert Fliess, Sándor Ferenczi, a partir de seus artigos Técnica psicanalítica (1918a/2011) e Elasticidade da técnica psicanalítica (1928/2011) e da construção, pelo autor húngaro, do conceito de "tato psicanalítico" - ideia que, como vimos nos capítulos anteriores, possui grande importância para Ferenczi de forma que o analista se distancie de uma postura rígida e evite a reprodução da situação traumática no ambiente analítico. Bolognini reconhece que desde o mais antigo destes dois trabalhos, Ferenczi já apontava a importância da empatia para o trabalho analítico como uma sensibilidade especial sem a qual seria impossível sequer compreender os conflitos psíquicos do analisando. O autor destaca então a seguinte passagem do segundo desses textos de Ferenczi:

\footnotetext{
Se, com a ajuda de nosso saber, inferido da dissecação de numerosos psiquismos humanos, mas sobretudo da dissecação do nosso próprio eu, conseguirmos tornar presentes as associações possíveis ou prováveis do paciente, que ele ainda não percebe, poderemos - não tendo, como ele, de lutar com as resistências adivinhar não só seus pensamentos retidos, mas também as tendências que lhe são inconscientes. (Ferenczi, 1928/2011, p. 31, grifado no original)

O psicanalista italiano aponta que a citação acima nos mostra a assimetria da relação analítica (da mesma forma que Ogden o fez, como vimos há pouco), sendo exatamente essa relação egodistônica o que permite que o analista opere em sua posição: “[...] analista e paciente não estão em 'concordância', são assimétricos e justamente isso permite ao analista fornecer ao outro um conhecimento que o outro não possui sobre si próprio" (Bolognini, 2002/2008, p. 54). O italiano cita ainda mais uma passagem do artigo de Ferenczi de 1928:
} 
Sem dúvida alguma, serão numerosos aqueles - não só entre os principiantes mas também entre todos os que têm uma tendência para o exagero - que se aproveitarão de minhas proposições acerca da importância do 'sentir com' para enfatizar, no tratamento, o fator subjetivo, isto é, a intuição, e subestimar o outro fator que sublinhei como sendo decisivo, a apreciação consciente da situação dinâmica. (Ferenczi, 1928/2011, p. 41, grifado no original)

Percebemos, nesse fragmento, a preocupação de Ferenczi a respeito da difícil tarefa do analista em manter seu funcionamento em dois níveis, o do sentir e o do pensar - não se trata, portanto de um simples ato intuitivo, mas de algo largamente dependente do treinamento do analista. Bolognini transporta essa preocupação para sua noção de empatia - é possível identificar por diversas vezes na obra do autor uma tentativa de desmitificar esse conceito, diferenciando a empatia corriqueira da empatia analítica.

Para explicar como entende essa diferença, o autor (2002/2008) recorre a uma charge, na qual uma senhora, ao lado de um gato sentado no parapeito, observa pela janela um homem e seu cachorro brincando alegremente com uma bolinha no jardim. A perspectiva da charge nos posiciona atrás da senhora e seu gato, indicando que a fala na legenda corresponde à da senhora, que diz ao gato: "Não te preocupes, eles não estão se divertindo, estão só fingindo" (Bolognini, 2002/2008, p. 222). O autor propõe então uma análise da charge. O humor ali, segundo Bolognini, reside no fato de que a mulher parece estar convicta de que o gato está vivenciando sentimentos de exclusão e ciúmes, demandando então o seu consolo:

O riso nasce, então, da descarga de uma tensão; por um instante nos entristecemos e nos assustamos ao nos reconhecermos, sem nos darmos conta, naquele gato no limiar do trauma, mas logo pensamos que não é verdade, não pode ser verdade, seja como for, os gatos não 'raciocinam' como nós e, portanto, é tudo uma ficção. Bem, a análise da vinheta poderia prosseguir, mas aqui me detenho porque o nível de análise que me interessa, para nosso tema, é: aquela mulher, que presumivelmente não é psicanalista, compreendeu a vivência de uma criatura que não tem o dom da palavra. (Bolognini, 2002/2008, p. 223)

A base da empatia comum que Bolognini descreve na charge é a mesma que percebia nos escritos de Ferenczi de tantos anos antes (Bolognini, 2002) - a capacidade de colocar-se no lugar de um outro. É o tipo de habilidade que leva um jovem a ceder seu lugar a um idoso no ônibus - não pela crítica que pode receber caso não o faça, mas por colocar-se na situação daquela pessoa de idade que luta para equilibrar-se no movimento do coletivo. $\mathrm{O}$ autor sugere que a possibilidade de vivenciar situações que envolvam uma atitude empática é maior em pessoas que 
tenham atingido suficiente nível de individuação, percebendo-se como alguém separado do outro - só é possível perceber a perspectiva do outro se o outro é visto como tal:

A vívida experiência compartilhada de áreas de contato fusionais específicas destinadas à comunicação íntima é possível justamente quando as pessoas conseguirem a discriminação, individualização e um sentido de si mesmo suficientemente sólido e definido em seus limites. A identificação sensu strictu está nas antípodas desta condição. (Bolognini, 2008/2009, p. 163)

Embora essa capacidade empática ordinária seja desejável para o psicanalista - já que representa certo nível de maturidade emocional - ela não é o bastante para caracterizar o que Bolognini chama de empatia analítica. $\mathrm{O}$ autor declara que concorda com Kohut ao perceber a empatia analítica como um método, e não uma mera eventualidade. Tampouco depende exclusivamente de uma atitude de simpatia ou benevolência de parte do analista. Por outro lado, afirma discordar de Modell, que percebia a empatia como um ato voluntário de parte do analista: “[...] a experiência e as discussões com os colegas, com o tempo, me confirmaram que o analista decidido a empatizar se coloca sobre uma rua sem saída e vai ao encontro pelo menos de uma clausura do pré-consciente, e inclusive a um destino complexo e caricatural [...]" (Bolognini, 2008/2009, p. 162). Uma importante característica que o psicanalista italiano atribui à empatia é justamente que ela não pode ser planejada ou programada, ocorrendo apenas através de eventuais aberturas nos canais pré-conscientes do analista, do paciente ou de ambos. Bolognini (2002/2008) cita então uma outra metáfora metereológica, que havia sugerido já alguns anos antes:

Poder-se-ia dizer que dias limpos e luminosos são desfrutados e apreciados, podem certamente ser desejados, mas não podem ser exigidos e planejados. Com efeito, a metáfora da impossibilidade de decidir sobre o tempo metereológico, válida a meu ver para os altos picos da autêntica empatia, não pode ser considerada completamente satisfatória quando se trata da disposição interna do analista; dele se requer certo grau de confiabilidade e de estabilidade funcional, razoavelmente superior às de uma pessoa comum. Poder-se-ia talvez dizer que um psicanalista que tenha passado por um percurso complexo e regular de formação poderia ser comparado a uma pessoa que tenha se mudado para uma região com um clima particularmente favorável, cuja variabilidade, naturalmente, não eliminável, possa se manifestar dentro de determinados limites, não demasiadamente amplos, especialmente vantajosos quando comparados com a região de proveniência. (Bolognini, 2002/2008, p. 226) 
Embora tenha sido escrito alguns anos antes, este exemplo encontra imediata correspondência no primeiro. Ao comentar a imprevisibilidade da empatia, Bolognini sugere que uma formação psicanalítica favorece a ocorrência de situações empáticas, ainda que inevitavelmente essa passagem se feche novamente quando as nuvens tornam a aparecer. Ademais, o autor (2002/2008) ressalta ainda que os afetos do analista (como os de qualquer pessoa) são igualmente impossíveis de se programar - são complexos e sua vivência consciente será sempre parcial. Daí a importância da consideração da dinâmica contratransferencial, que havia sido veementemente ressaltada por Ferenczi e Winnicott.

Bolognini percebe a experiência contratransferencial como um fator crucial para que o analista adentre o mundo interno do paciente, ainda que seja importante manter certo distanciamento - caso o analista permaneça identificado contratransferencialmente, estará preso à repetição da cena interna, sem a capacidade de compreendê-la e interpretá-la, o que era justamente a preocupação de Ferenczi, como mencionamos anteriormente. Por outro lado, ao elaborar a experiência contratransferencial, o analista permite o desenvolvimento de uma empatia ampla e profunda que transcende a concordância egossintônica - o que ficará claro em um dos casos clínicos de Bolognini que abordaremos a seguir.

\subsubsection{Aplicações clínicas da empatia psicanalítica}

Bolognini é um autor de imensurável riqueza na discussão de casos clínicos. Seu estilo simples e poético expõe com clareza os fenômenos que se propõe a abordar, estimulando um diálogo com o interlocutor. Sua coragem ao expor seus sentimentos na situação - seja raiva, insegurança, tédio ou ansiedade ajuda a compor o cenário interpsíquico que o autor se preocupa em retratar. Dessa forma, optamos aqui pelo relato de dois casos que servem de exemplo para o uso da empatia no ambiente analítico e do manejo dos conteúdos regressivos não verbais na relação analítica.

O primeiro é o de Alessandra, uma jovem de vinte e seis anos, no segundo ano de análise na ocasião do relato de Bolognini. A paciente, segundo a descrição do autor, era graciosa, de boa aparência, inteligente e, a seu ver, consideravelmente inautêntica. Demasiadamente observadora em relação ao analista, detectava cada 
mudança de expressão sua, obrigando-o a se esforçar em manter uma aparência neutra. Na sessão que o analista descreve, Alessandra chegou ao consultório da forma habitual, “[...] com seus movimentos estudados de uma jovem refinada de boa família” (Bolognini, 2002/2008, p. 164). Após um breve silêncio, a paciente diz ao analista que está em dificuldades com os irmãos, já que seus pais se comprometeram a comprar-lhe um apartamento para que possa se casar com seu companheiro. Ela indaga então a Bolognini: "Devo sentir-me culpada?" (Bolognini, 2002/2008, p. 164). O relato do analista sobre esse momento serve de precisa ilustração para sua experiência intrapsíquica:

A paciente inclina um pouco a cabeça na minha direção, e deixa entrever uma olhadela de cumplicidade, infantilmente brincalhona; um olhar que parece solicitar fortemente minha adesão, de antemão, a algo que a paciente tem em mente, mas que não está manifesto. Se eu fosse responder sintonicamente àquela parte que ela está me oferecendo, sinto que deveria exclamar prontamente, com absolvição redentora e tranquilizadora: 'Mas claro que não, a senhora não deve sentir-se culpada!' (Bolognini, 2002/2008, p. 164)

O autor nos informa que, após algum tempo em análise, Alessandra já devia esperar que ele não lhe respondesse prontamente, o que o analista optou por fazer. Este se manteve em silêncio até que Alessandra tornasse a falar, dizendo que sua tia poderia lhe conseguir um emprego, mas inventa desculpas para não fazê-lo. Acha que sua tia não quer que ela se case e, novamente, solicita a participação de Bolognini: "Devo afastar-me dela, não é? O que o senhor acha, doutor?" (Bolognini, 2002/2008, p. 165). Mais uma vez, Bolognini nos expõe sua reação interna imediata:

Novamente, observo a mesma inclinação lateral da cabeça, a mesma pausa de antes, a olhadela de lado observando-me e fazendo o possível para conseguir uma resposta; experimento uma sensação de pressão e dificuldade, como se estivesse sendo manipulado. O mais notável é que Alessandra está se comportando tão comme il faut que pareceria um sinal de má educação e mau gosto se eu não lhe respondesse prontamente: 'Mas é óbvio! A senhora deve afastar-se de sua tia!' (Bolognini, 2002/2008, p. 165)

Percebendo seu incômodo a partir de um sentimento de confusão ao não conseguir perceber a paciente na situação, o analista permanecia sem intervir. Os pensamentos de Bolognini passeiam por um livre caminho ao indagar-se sobre o que estava acontecendo ali, até que ouve a paciente dizer que quando estiver casada vai exigir de seu marido cumplicidade - a demanda que o analista sentia desde o início, sem conseguir identificar. Ele lhe pergunta então por que cumplicidade e não 
solidariedade ou aliança. A paciente lhe responde que estes não bastam, cumplicidade é mais. Ao refletir sobre essa questão - o cúmplice geralmente participa de alguma atividade ilícita - Bolognini reage:

Digo à paciente: 'Tenho a sensação que hoje a senhora está me pedindo cumplicidade, e não compreensão'. Pergunto-lhe: 'Por que, em relação a quê?' Ao fazer essas perguntas procuro mostrar-lhe meu interesse, mas também um certo distanciamento pessoal. Em outras palavras, ofereço-lhe solidariedade mais do que cumplicidade: proximidade na separabilidade, e não confusão. (Bolognini, 2002/2008, p. 166)

Após alguns minutos de silêncio, Alessandra diz estar com frio e começa a tremer. $\mathrm{O}$ autor relata então a cena regressiva que se estabelece na sessão, a partir da transformação de uma jovem de boa família em uma menininha confusa e assustada. Começa a falar sobre seus medos - redutíveis ao medo primitivo medo da solidão -, começando a chorar convulsivamente logo em seguida. Bolognini diz então:

\begin{abstract}
Nesse momento sinto surgir em mim um estado de profunda empatia com a paciente que me permite compreendê-la e entrar em contato mais genuíno com ela. Foi-se o falso self que recusava o medo da separação projetando-o na tia, que negava o sentimento de culpa e a ansiedade ligados à separação e que vivenciava as ligações afetivas como incômodos perseguidores externos (na realidade, partes não reconhecidas como próprias que 'voltavam para si', e com as quais teria preferido nada ter a ver, e que quando postas fora da porta, voltavam pela janela). Tenho agora a clara percepção de ter reencontrado Alessandra: amedrontada pela perspectiva de crescimento de vida, aterrorizada pelos fantasmas de abandono, mas autêntica. (Bolognini, 2002/2008, p. 167)
\end{abstract}

Bolognini entende, então, que a cumplicidade que lhe fora evocada se referia ao conluio que deveria formar com o falso self da paciente para tirar definitivamente de ação sua porção infantil e amedrontada - um dos momentos que evidenciam suas influências winnicottianas. As vestes de "refinada jovem de boa família" - o falso self da paciente - se originaram da traumática situação primária na qual vivia uma relação de pouco contato emocional com sua mãe. Esta se investia intensamente no trabalho, passando pouco tempo com a filha, momentos nos quais buscava sempre antecipar-se às queixas de Alessandra ao impor-lhe atividades programadas, como leituras, arrumação do quarto ou qualquer coisa que ajudaria a evitar o contato afetivo entre as duas. Assim, percebemos a essência winnicottiana presente no conceito de trauma para Bolognini, especialmente no que se refere ao evento traumático vivido e reproduzido por Alessandra - de acordo com Bolognini (2008), o trauma se engendra na experiência primária quando ocorre uma 
dissociação do par mãe-bebê, interrompendo precocemente os fluxos de sensações e emoções entre ambos. No caso desta paciente, como a mãe não a reconheceu, sequer proporcionando-lhe espaço para o brincar (a criatividade, a espontaneidade), a paciente aprendera a simplesmente reagir aos estímulos invasivos do ambiente, desenvolvendo um falso self patológico, essa jovem de boas maneiras, que ocultava uma porção infantil e assustada. Os momentos finais da sessão foram voltados para a análise desse mecanismo de defesa, assim como as sessões que ocuparam o meses seguintes. Bolognini considera, então, que o elemento chave para alcançar essa percepção empática e, assim, atingir a rígida defesa que se apresentava diante dele, foi justamente o exame a que submeteu sua experiência contratransferencial.

Nosso segundo caso envolve uma curiosa situação vivenciada por Bolognini, que nos é relatada em seu livro Passagens secretas (2008/2009). O autor descreve uma sessão de uma paciente chamada Mônica, de trinta e quatro anos, casada e sem filhos. $\mathrm{O}$ autor a caracteriza como alguém muito normal, gentil e correta. Se comporta "bem" na análise, buscando sempre apresentar um sorriso ao chegar, esforçando-se para não criar situações de conflito com o analista. Grande parte das sessões recai sobre a descrição de problemas de relacionamento fora do ambiente analítico, o que faz com que Bolognini se sentisse como se ainda não tivesse adentrado a experiência desta análise.

Em certa sessão, próxima a uma breve interrupção, Mônica chega perturbada ao consultório de Bolognini. Enquanto estava no caminho, a paciente encontrou na rua com um homem que lhe parecia o Dr. D., amigo de seu marido com quem haviam jantado algumas vezes recentemente. Cumprimentaram-se e pararam para trocar algumas palavras. No entanto, ao se aproximar, se deu conta de que aquele não era de fato o Dr. D., mas alguém muito parecido com ele. Enquanto Mônica passava por um momento de pânico, incapaz de dizer qualquer palavra, o sósia do Dr. D. não expressou qualquer ideia que mostrasse perplexidade com a situação - sem dizer que, na verdade, não a conhecia. Mônica pensou que ele talvez tenha tido a semelhante impressão de que a conhecia de algum lugar e estava ganhando tempo para se lembrar de onde a tinha visto. Bolognini diz então: "Estou muito interessado neste ponto do relato por motivos analíticos e também porque, num plano humano, a situação mesma se configurou como cada vez mais 
desagradável e estapafúrdia, ao ponto de que - como se costuma dizer - 'começo a estar mal eu no seu lugar"” (Bolognini, 2008/2009, p. 168). A seguir, enquanto a paciente continua seu relato do ocorrido, Bolognini experimenta seu desconforto, acrescentando:

Escutando o relato de Mônica, minha cabeça toma desde o começo duas direções diferentes: por um lado, identifico-me parcial e conscientemente (immedesimo) com a vivência subjetiva egossintônica de Mônica e, neste sentido, a experiência que vivo se parece com um verdadeiro pesadelo, dado que a incomodidade social da cena se soma à sensação de aprisionamento e de impossibilidade de reagir de modo libertador. Colateralmente a isto [...] não pude evitar perceber em mim a tentativa de distanciar-me desta forma de identificação. Encontro-me pensando que aquela situação era absolutamente bizarra, como que para desrealizá-la ou não dar tanta importância; assim me encontro dizendo-me que no fundo aconteceu com ela e não comigo. (Bolognini, 2008/2009, p. 169)

Mônica encerra então seu relato, dizendo que ambos se despediram da mesma forma que haviam conversado, com votos cordiais de saúde - de forma tão superficial quanto podiam. Um certo silêncio tem lugar, e Bolognini pensa que existe o risco de que a mesma situação se reproduza na análise. Supõe que caso interprete o conteúdo que lhe foi apresentado, Mônica entenderá intelectualmente e os dois estarão de acordo, sem que se alcance o núcleo da questão. Passados alguns instantes, Mônica quebra o silêncio: "Mais que ter confundido aquele tipo com o Dr. D., me impressiona o fato de não haver sido capaz de dizer que me havia equivocado. Por quê? O que temia?" (Bolognini, 2008/2009, p. 171). O analista nos diz que sabia o que ela temia porque havia vivenciado aquilo ao identificar-se com a paciente parcial e conscientemente.

Um novo período de silêncio acontece - sustentado pelo analista para dar espaço aos pensamentos de Mônica, que está em um processo de elaboração que Bolognini diz saber estar acontecendo, já que a paciente chegara à capacidade de transmitir o que estava se passando com ela ao analista nessa relação empática. Podemos inferir que a atitude de Bolognini, ao sustentar o silêncio do paciente, encontra certa fundamentação no uso que Balint (1969) fazia do silêncio na situação analítica. Como vimos anteriormente, o autor húngaro entendia que o silêncio não representa necessariamente uma resistência, mas uma forma de regressão para o nível da criação, situação na qual, embora saibamos que não existam objetos, o sujeito nunca está exatamente sozinho. Balint destaca que, através do silêncio, o paciente pode fazer algo a respeito do que lhe está incomodando e este algo será 
produto de sua criação genuína. Neste momento de criação, não é possível que o analista esteja com o paciente, embora possa permanecer como um observador externo, mas pode se fazer presente tanto antes quanto depois que o paciente emerge desse estado. Em um momento oportuno, Bolognini ecoa então a pergunta anterior da paciente, indagando-lhe o que poderia ter temido:

Formulo a pergunta em uma condicional que permite e até favorece uma área potencial de busca um pouco vaga, genérica e não imperativa. Do modo com que pergunto, favoreço em Mônica a sensação de que eu não tinha em mente uma coisa precisa e que estou interessado no que ela possa pensar. Isto é importante: minha pergunta deve abrir um espaço e não fazê-la se sentir pressionada por um interrogatório. (Bolognini, 2008/2009, p. 173)

A paciente responde então, após um suspiro, que fora o papelão que passou - haviam dois, o dela e o dele, algo que lhe parecia insustentável. Ao sentir-se liberado de um peso interno, Bolognini lhe acrescenta que ela parece estar começando a aguentar o peso desse papelão, seguindo-se um clima de difícil trabalho cumprido entre os dois.

A partir desses dois relatos clínicos, nos foi possível um vislumbre do uso que Bolognini faz da empatia analítica. Como envolve uma dinâmica interpsíquica a nível profundo, não verbal, a descrição dos eventos que ocorrem no ambiente analítico parece muito difícil, embora o estilo de escrita de Bolognini contorne, por muitas vezes, essa dificuldade. Por outro lado, a compreensão adquirida a partir dos sentimentos despertados no próprio analista, empaticamente orientado, pela paciente lhe favoreceram um vislumbre sobre o mundo interno da paciente. Como nos diz Bolognini: “A empatia psicanalítica compreende a possibilidade de aceder com o tempo, através da elaboração contratransferencial, também à reintegração de componentes cindidos, não apenas hipotetizados - de forma artificial - senão experimentados e reconhecidos pelo analista num regime de conhecimento vivencial" (Bolognini, 2008/2009, p. 180). No caso, o trauma compreendido por Bolognini envolve a vida artificial que caracterizava os pais de Mônica - eram figuras públicas, com grande preocupação em transparecer um modelo ideal de harmonia afetiva familiar. Seus pais lhe transportaram então essa noção, o que pode se confirmar pela queixa da paciente quanto à aparente inautenticidade com que estabelece suas relações pessoais - um falso self que reproduz com exatidão a mesma defesa utilizada pela família. Percebemos, através do caso de Mônica, que 
a empatia envolve uma experiência provocada pelo material presente no mundo interno do paciente.

Prefiro considerar que podemos compartilhar também das coisas de que não nos damos conta, mas que se originam do mundo interno do paciente, e são experienciadas de modo autêntico e intenso, a ponto de produzirem algum efeito em nós; não me refiro às coisas compreendidas sobre o paciente, mas às coisas vividas junto com ele, mesmo que não compreendidas. (Bolognini, 2002/2008, p. 141)

Por outro lado, no caso de Alessandra entendemos a importância da operação a nível técnico de forma paralela à experiência de sentir com; no caso, manifestada de forma que o analista não acedesse ao convite de sua paciente à cumplicidade:

Em condições ótimas, o analista consegue um bom contato emocional consigo mesmo e com o paciente, e mantém um nível adequado de domínio técnico do processo; o compartilhar das vivências se realiza em grau significativo, mas parcial, de modo a não sequestrar completamente as funções egóicas do analista. (Bolognini, 2002/2008, p. 140)

Percebemos, então, a pertinência das contribuições de Bolognini a respeito da empatia e da relação interpsíquica para a elaboração dos traumas primitivos. Como se trata de situações que remetem a um momento precoce, vivenciadas a nível corporal e sem chance de representação no psiquismo, são experiências as quais o paciente encontra muita dificuldade para comunicar por meios verbais. A empatia de Bolognini, calcada na ideia de tato psicanalítico de Ferenczi (1928/2011), surge então como uma importante ferramenta terapêutica à disposição do psicanalista para lidar com estados regressivos, compreendendo o material que o paciente tenta comunicar - o sofrimento advindo do trauma - a partir da forma com que o analista é afetado por ele.

Constatamos, dessa forma, que os três autores escolhidos para esse capítulo, embora contemporâneos entre si e com muitas influências em comum, adotam práticas bastante diferentes. A clínica de Bollas parece ter um caráter mais diretivo. Sua preocupação em inquirir o paciente a respeito do que havia precedido o colapso, bem como a equipe reunida para atender o paciente em crise evidenciam uma clínica mais calcada na realidade, com uma essência pragmática para além do consultório - mas, de acordo com as ideias do autor, não além do setting, que é ampliado tanto espacial quanto temporalmente. Por outro lado, as concepções de 
Ogden sobre o terceiro analítico e o uso da rêverie demonstram a construção de um setting mais íntimo, com maior proximidade entre analista e paciente. As explorações de Bolognini pelo campo intersubjetivo demonstram alguma consonância com a proposta de Ogden - principalmente ao encontrar o uso da rêverie como ponto em comum, bem como a atuação sobre o campo que desenvolve entre analista e paciente. De forma geral, podemos concluir que os três oferecem visões enriquecedoras a respeito da clínica do trauma, desenvolvendo novas ferramentas para a elaboração do conteúdo não verbal e o manejo da regressão na contemporaneidade. 


\section{Considerações finais}

No decorrer deste longo percurso psicanalítico, iniciado nos primeiros escritos de Freud e que culminou nas contribuições da psicanálise contemporânea, fomos capazes de encontrar significativas reflexões a respeito do manejo clínico da manifestação de situações traumáticas no setting analítico. As contribuições de Ferenczi sobre uma atitude mais elástica por parte do analista, em detrimento da postura rígida que, em alguns momentos, poderia beirar uma perversidade científica, trouxe uma dimensão relacional mais humana para o contexto psicanalítico, como podemos perceber pela importância do reconhecimento do paciente e seu sofrimento na relação terapêutica através do tato psicanalítico. Sua construção sobre a teoria do trauma, constituído em princípio a partir de uma situação violenta, invasiva, após a qual a criança não encontra o apoio do adulto em uma tarefa que ainda não lhe é possível desempenhar, isto é, a representação do evento, fornece uma perspectiva deveras interessante para a clínica.

Como vimos, Ferenczi sublinha a atitude hipócrita do analista como uma reedição desse segundo tempo do trauma - o desmentido -, dificultando de forma equivalente a repetida tentativa do paciente de elaborar o conteúdo traumático não representado e o estabelecimento de uma relação de confiança no ambiente analítico, o que proporcionaria uma segurança ao analisando que lhe permitisse explorar o trabalho desse conteúdo. Diante da hipocrisia profissional do analista, portanto, pouca escolha teria o analisando além de continuar em um ciclo repetitivo de angústia relativo ao trauma sofrido, sem que uma saída pudesse ser encontrada.

Notamos ainda como as experiências clínicas de Ferenczi influenciaram gerações posteriores de analistas, seja de forma direta, como podemos perceber em Balint, ou indireta, como é possível inferir em Winnicott. Todos esses três autores sugeriam um tipo de trabalho muito diferente ao lidar com os sofrimentos primitivos de pacientes borderlines e psicóticos, e muitas vezes foram alvos de críticas que questionavam se aquilo que propuseram seria mesmo uma forma da psicanálise. Em comum entre eles podemos perceber um grande interesse a respeito dos fenômenos primitivos, pré-edípicos. No entanto, devemos recordar que nenhum 
deles exclui a técnica clássica e a análise dos conflitos edipianos de seu arcabouço técnico. Winnicott destaca ao longo de sua obra que as técnicas de manejo diante de casos regressivos devem ser empregadas apenas pelos analistas já experientes no uso da técnica clássica, desenvolvendo análises marcadas proeminentemente sobre um material edipiano - como percebemos na segunda análise de Margaret Little com ele (Little, 1990), por exemplo.

Balint também marca a importância e a validade do uso das interpretações em casos de regressão ao âmbito edipiano - o que está em jogo, nesse caso, é a perspicácia do analista em reconhecer que tipo de fenômeno está tomando lugar na relação analítica, de modo a construir uma atitude mais adaptada às necessidades do paciente. Essa preocupação é evidenciada na sua discussão a respeito dos casos de regressão benigna e maligna, sendo o analista capaz de favorecer uma ou outra modalidade de regressão de acordo com seu reconhecimento sobre o sofrimento do paciente e a atitude que adota diante dessa situação.

Outro ponto importante no qual esses autores se encontram reside no maior protagonismo atribuído às experiências não verbais, tanto no desenvolvimento psíquico quanto no ambiente clínico. Ao questionarmos a interpretação enquanto uma construção exclusivamente verbal, considerando os afetos transferenciais e contratransferenciais da relação analítica, podemos nos engajar na abordagem de conteúdos bastante primitivos. A psicanálise clássica considerava que os indivíduos não neuróticos não poderiam ser analisados devido a sua enorme dificuldade de representação. $\mathrm{O}$ estabelecimento da neurose de transferência nestes casos seria, portanto, impossível. Todavia, quando Winnicott introduz e explora o conceito de psicose de transferência, tão vivenciado no caso de Margaret Little, abarca em sua técnica uma ampla gama de fenômenos limítrofes e psicóticos. Balint também enveredaria por essas águas, embora chamasse essas experiências de regressões ao âmbito da falha básica, como nos foi possível perceber.

Quando refere-se aos sofrimentos derivados de traumas primitivos, Winnicott utiliza o termo "agonias impensáveis". Como grande parte dos conceitos winnicottianos, essa expressão comporta uma impressionante simplicidade, enquanto conserva, paradoxalmente, uma dimensão significativamente complexa. Se trata de angústias cuja origem se encontra além da linguagem, não nas falhas 
maternas relativas à sua gradual e estruturante desadaptação, mas no fracasso da adaptação materna no âmbito da dependência absoluta. Já que não havia uma linguagem verbal estruturada então, seria logicamente impossível rememorar e elaborar esses eventos traumáticos por meio da interpretação verbal. Isso deve ocorrer então através de um procedimento não-verbal, isto é, a partir do manejo, conforme discutido em nosso terceiro capítulo. Ainda assim o trabalho verbal pode conservar alguma efetividade, como podemos notar pela função do analista que Balint descreve como de informante, ao traduzir as atitudes do paciente regredido de forma que se permita a representação do material traumático.

Entendemos, assim, que os autores aqui abordados oferecem uma concepção bastante diferente a respeito da regressão no ambiente analítico daquela de Freud, que a considerava principalmente um inconveniente mecanismo de defesa (Freud, 1926/2014). Balint e Winnicott, seguindo Ferenczi, percebiam o grande potencial que residia na regressão enquanto um campo para a atualização do conteúdo não representado, por meio do estabelecimento de um ambiente mais adequado que favorecesse a resolução do trauma cristalizado. Daí a importância percebida por Ferenczi de que o analista não reproduzisse o ambiente original, para que fosse possível estabelecer um novo contexto - e um novo começo - para o paciente.

Realizamos então uma breve exploração pela base conceitual de três importantes autores da psicanálise contemporânea, Christopher Bollas, Thomas Ogden e Stefano Bolognini. É possível identificar, nos dias atuais, uma grande quantidade de autores que se aventura no campo dos sofrimentos primitivos e da clínica além da modalidade clássica de interpretação, o que nos mostra o imenso alcance que tiveram as propostas de Ferenczi, Balint e Winnicott. No entanto, optamos pela discussão das propostas de Bollas, Ogden e Bolognini apenas, justamente por apresentarem tanto uma fundamentação teórico-clínica que engloba muitas das ideias desses autores quanto pela sua equivalente coragem em explorar novas configurações de setting e inovadores meios para lidar com os fenômenos primitivos no ambiente analítico. Os inúmeros relatos clínicos de Ogden, focados no campo intersubjetivo transferencial-contratransferencial - o terceiro analítico -, assim como sua descrição sobre o uso da rêverie nos abrem muitas portas para lidar 
com um material que, embora não podendo ser comunicado verbalmente pelo paciente, acaba por encontrar outros meios de expressão. Ao mesmo tempo, a proposta de Bolognini sobre a empatia pode ser percebida como complementar à de Ogden, dirigindo seu foco para as experiências compartilhadas no setting analítico, resultando em uma representação do material interno do paciente a partir do exame da contratransferência do analista. Da mesma forma, devemos valorizar as radicais experiências que Bollas vem desenvolvendo ao longo dos últimos trinta anos com pacientes em situação de colapso psíquico, através de uma dilatação do setting analítico, relatando os efeitos da inserção de novos personagens nessa dinâmica. Nos foi possível perceber, portanto, que a psicanálise contemporânea vem construindo uma proposta clínica deveras original, o que fica explícito na sugestão de um vocabulário psicanalítico renovado e singular, ao mesmo tempo em que conserva em sua essência a tradição de autores como Ferenczi, Winnicott e Balint.

Podemos concluir, então, que a partir das variadas perspectivas clínicas abordadas, diferentes entre si ainda que compartilhem essencialmente algo em comum, foi possível compreender e explorar a questão do trauma e suas repercussões na constituição subjetiva individual, e da regressão enquanto ferramenta terapêutica no campo intersubjetivo analítico ao longo dos tempos. Destacamos, nesse sentido, o papel exercido pelas formas não verbais de comunicação que se desenrolam no setting analítico para a elaboração do conteúdo traumático primitivo. A compreensão das forças dinâmicas atuantes na situação analítica, cada uma permeada por sua própria história e linguagem, se mostra então fundamental. 


\section{Referências bibliográficas}

ARIÉS, Philippe. (1973). História social da criança e da família. Rio de Janeiro: LTC, 1981.

BALINT, Michael. (1933a). Dr. Sándor Ferenczi as psycho-analyst. In. Problems of human pleasure and behaviour. Londres: Maresfield Library, 1987.

. (1933b). On transference of emotions. In. Primary love and psychoanalytic technique. Londres: Karnac Books, 1994.

(1937). Early developmental states of the ego. Primary object love. In.

Primary love and psycho-analytic technique. Londres: Maresfield Library, 1975.

. (1957). The doctor, his patient and the illness. Londres: Pitman Medical, 1968.

(1959). Thrills and regressions. Madison, CT: International Universities Press Inc., 1987.

(1969). The basic fault: Therapeutic aspects of regression. Evanston, IL: Northwest University Press, 1992.

BION, Wilfried. (1962). Learning from experience. Nova York, Basic Books, 1962.

BIRMAN, Joel. (1996). Freud e Ferenczi: Confrontos, continuidades e impasses. In. KATZ, Chaim S. (org.). Ferenczi: História, teoria, técnica. São Paulo: Editora 34, 1996.

BLEGER, José. (1967). Simbiose e ambiguidade. Rio de Janeiro: Francisco Alves, 1988.

BLEICHMAR, Norberto M.; BLEICHMAR, Celia L. (1989). A psicanálise depois de Freud: Teoria e clínica. Porto Alegre: Artes Médicas, 1992. 
BOKANOWSKI, Thierry. (1997). A prática analítica. Rio de Janeiro: Imago, 2002.

. (2000). Sándor Ferenczi. São Paulo, Via Lettera: 2000.

BOLLAS, Christopher. (1978). The transformational object. In. The Christopher Bollas reader. Nova York: Routledge, 2011. . (2013). Catch them before they fall. Nova York: Routledge, 2013.

BOLOGNINI, Stefano. (2002). A empatia analítica. Rio de Janeiro: Companhia de Freud, 2008. . (2008). Passagens secretas. São Paulo: Casa do Psicólogo, 2009.

BONAMINIO, Vincenzo. (2008). O não-interpretar: algumas considerações sobre a contribuição de M. Balint e dois fragmentos clínicos. In. Revista Brasileira de Psicanálise, v. 42, n. 1, pp. 172-186, 2008.

BORGOGNO, Franco. (1999). Psicanálise como percurso. Rio de Janeiro: Imago, 2004.

CASADORE, Marcos M. (2012). Sándor Ferenczi e a psicanálise: Pela errância das experimentações. São Paulo: Cultura Acadêmica, 2012.

COELHO JUNIOR, Nelson Ernesto. (2004). Ferenczi e a experiência de Einfuhlung. In. Ágora, v. 7, n. 1, p. 73-85, 2004. (2013). Tempo do sonho, tempo da rêverie e o terceiro-analítico. In. Caderno de Psicanálise CPRJ, Rio de Janeiro, v. 35, n. 28, p. 49-60, 2013.

DAL MOLIN, Eugenio C. (2016). O terceiro tempo do trauma. São Paulo: Perspectiva, 2016.

DAVIS, Madeleine \& WALLBRIDGE, David. (1981). Limite e espaço: uma introdução à obra de D. W. Winnicott. Rio de Janeiro: Imago, 1982. 
DI CHIARA, Giuseppe. (2016). Psychoanalysis in Italy. In. BORGOGNO, F., LUCHETTI, A. \& MOE, L. M. (org.). Reading italian psychoanalysis. Nova York: Routledge, 2016.

DIAS, Elsa O. (2006). O caráter temporal e os sentidos de trauma em Winnicott. In. Winnicott e-Prints, v. 1, n. 2, série 2, 2006. . (2008). O uso da interpretação na clínica do amadurecimento. In. Revista Latinoamericana de Psicopatologia Fundamental, v. 11, n. 4, p. 588-601, dez. 2008

DUPONT, Judith. (1998). The concept of trauma according to Ferenczi. In. International Forum of Psychoanalysis, n. 7, v. 4, p. 235-241, 2010.

. (2000). La notion de trauma selon Ferenczi et ses effets sur la recherché psychanalytique ultérieure. In. Filigrane, printemps, p. 19-31, 2000.

EQUILIBRISTA, O. Direção: James Marsh. Produção: Simon Chinn. Roteiro: Philippe Petit. Califórnia Filmes, 2008. 1 DVD (94 minutos).

FAIRBAIRN, W. Ronald D. (1940). Fatores esquizoides na personalidade. In. Estudos Psicanalíticos da Personalidade. Tradução de Eva Nick. Rio de Janeiro: Interamericana, 1980.

FERENCZI, Sándor. (1909). Transferência e introjeção. In. Obras completas, volume 1. São Paulo: Editora WMF Martins Fontes, 2011.

. (1912). O conceito de introjeção. In. Obras completas, volume 1. São Paulo: Editora WMF Martins Fontes, 2011. (1913). O desenvolvimento do sentido de realidade e seus estágios. In. Obras completas, volume 2. São Paulo: Editora WMF Martins Fontes, 2011. (1918a). Técnica psicanalítica. In. Obras completas, volume 2. São Paulo: Editora WMF Martins Fontes, 2011.

(1918b). Psicanálise das neuroses de guerra. In. Obras completas, volume 3. São Paulo: Editora WMF Martins Fontes, 2011. 
(1921). Prolongamentos da 'técnica ativa' em psicanálise. In. Obras completas, volume 3. São Paulo: Editora WMF Martins Fontes, 2011.

(1924a). Thalassa: ensaio sobre a teoria da genitalidade. In. Obras completas, volume 3. São Paulo: Editora WMF Martins Fontes, 2011.

. (1924b). As fantasias provocadas. In. Obras completas, volume 3. São Paulo: Editora WMF Martins Fontes, 2011.

. (1924c). O sonho do bebê sábio. In. Obras completas, volume 3. São Paulo: Editora WMF Martins Fontes, 2011.

. (1926). Contraindicações da técnica ativa. In. Obras completas, volume

3. São Paulo: Editora WMF Martins Fontes, 2011.

(1927). O problema do fim da análise. In. Obras completas, volume 4. São Paulo: Editora WMF Martins Fontes, 2011.

(1928). Elasticidade da técnica psicanalítica. In. Obras completas, volume 3. São Paulo: Editora WMF Martins Fontes, 2011.

(1930). Princípio de relaxamento e neocatarse. In. Obras completas, volume 3. São Paulo: Editora WMF Martins Fontes, 2011.

(1931). Análise de crianças com adultos. In. Obras completas, volume 3. São Paulo: Editora WMF Martins Fontes, 2011.

(1933). Confusão de língua entre os adultos e a criança. In. Obras completas, volume 3. São Paulo: Editora WMF Martins Fontes, 2011.

. (1934). Reflexões sobre o trauma. In. Obras completas, volume 3. São Paulo: Editora WMF Martins Fontes, 2011.

(1985). The clinical diary of Sándor Ferenzi. Cambridge: Harvard University Press, 1988.

FIGUEIREDO, Luís Cláudio. (2002). A tradição ferencziana de Donald Winnicott. In. Revista brasileira de psicanálise, v. 36, n. 4, p. 909-927, 2002. 
FREUD, Sigmund. (1896). A etiologia da histeria. In. Ed. Standard brasileira das Obras Psicológicas Completas de Sigmund Freud, vol. 3. Rio de Janeiro: Imago, 1975.

. (1905). Três ensaios sobre a teoria da sexualidade. In. Sigmund Freud, Obras Completas, vol. 6. Tradução de Paulo César Lima de Souza. São Paulo: Companhia das Letras, 2016.

(1912). A dinâmica da transferência. In. Sigmund Freud, Obras Completas, vol. 10. Tradução de Paulo César Lima de Souza. São Paulo: Companhia das Letras, 2010.

(1914). Introdução ao narcisismo. In. Sigmund Freud, Obras Completas, vol. 12. Tradução de Paulo César Lima de Souza. São Paulo: Companhia das Letras, 2010.

(1916-17). Conferências introdutórias à psicanálise. In. Sigmund Freud, Obras Completas, vol. 13. Tradução de Paulo César Lima de Souza. São Paulo: Companhia das Letras, 2014.

(1920). Além do princípio do prazer. In. Sigmund Freud, Obras Completas, vol. 42. Tradução de Paulo César Lima de Souza. São Paulo: Companhia das Letras, 2010.

(1926). Inibição, sintoma e angústia. In. Sigmund Freud, Obras Completas, vol. 17. Tradução de Paulo César Lima de Souza. São Paulo: Companhia das Letras, 2014. (1939). Esboço de psicanálise. In. Ed. Standard brasileira das Obras Psicológicas Completas de Sigmund Freud, vol. 23. Rio de Janeiro: Imago, 1975.

FREUD, Sigmund \& FERENCZI, Sándor. (2000). The correspondence of Sigmund Freud \& Sándor Ferenczi, volume 3, 1920-1933. Combridge: Harvard University Press, 2000. 
GELLY, René. (1982). Aspectos teóricos do movimento Balint. In. MISSENARD, André. (org.). A experiência Balint: História e atualidade. São Paulo: Casa do Psicólogo, 1994.

GREENBERG, Jay R.; MITCHELL, Stephen A. (1983). Relações objetais na teoria psicanalítica. Porto Alegre: Artes Médicas, 1994.

GUNTRIP, Harry. (1975). Minha experiência de análise com Fairbairn e Winnicott. Psicanalítica. v. 2, n. 1, 223-245, 2001.

JOYCE, Angela \& CALDWELL, Lesley. (2011). Reading Winnicott. Nova York: Routledge, 2011.

KAHN, M. Masud R. (1960). Regressão e integração no setting analítico. Ensaio clínico sobre os aspectos transferenciais e contratransferenciais desses fenômenos. In. Psicanálise: Teoria, técnica e casos clínicos. Tradução de Glória Vaz. Rio de Janeiro: Francisco Alves, 1977.

KUPERMANN, Daniel. (2008). Presença sensível: a experiência da transferência em Freud, Ferenczi e Winnicott. In. Jornal de psicanálise, v. 41, n. 75, p. 75-96, $\operatorname{dez} 2008$.

LACAN, Jacques. (1975). O seminário - livro 1: os escritos técnicos de Freud. Rio de Janeiro: Jorge Zahar Editor, 1986.

LAPLANCHE, Jean \& PONTALIS, Jean-Bertrand. (1982). Vocabulário da psicanálise. São Paulo: Martins Fontes, 2001.

LEJARRAGA, Ana L. (2005). Sobre a ternura, noção esquecida. In. Interações, v. 10, n. 19, p. 87-102, 2005.

. (2008). Clínica do trauma em Ferenczi e Winnicott. In. Natureza humana, v. 10, n. 2, pp. 115-148, dez. 2008.

LITTLE, Margaret I. (1990). Ansiedades psicóticas e prevenção: Registro de uma análise pessoal com Winnicott. Rio de Janeiro: Imago, 1992. 
MORENO, Maria M. A. \& COELHO JUNIOR, Nelson E. (2012). Trauma, uma falha no cuidar? Diálogo entre Ferenczi e Winnicott. In. Psicologia USP, v. 23, n. 4, p. 707-719, 2012.

NATUREZA Selvagem, Na. Direção, roteiro e produção: Sean Penn.. Intérpretes: Emile Hirsch, Vince Vauhgn, Catherine Keener e outros. Paramount, 2007. 1 DVD NAFFAH NETO, Alfredo. (2008). O caso Margaret Little: Winnicott e as bordas da psicanálise. In. Jornal de psicanálise, v. 41, n. 75, p. 107-121, dez 2008.

(2010). As funções da interpretação psicanalítica em diferentes modalidades de transferência: as contribuições de D. W. Winnicott. In Jornal de psicanálise, v. 43, n. 78, p. 79-90, 2010.

NETTLETON, Sarah. (2016). The metapsychology of Christoper Bollas. Nova York: Routledge, 2016.

OGDEN, Thomas H. (1982). Projective identification and psychoanalytic technique. Nova Jersey: Jason Aronson, 1991.

(1989). The primitive edge of experience. Nova Jersey: Jason Aronson, 1989.

(1994). Subjects of analysis. Nova Jersey: Jason Aronson, 1994. (1997). Reverie and interpretation. Nova Jersey, Jason Aronson, 1997.

PEIXOTO JUNIOR, Carlos A. (2006). Trauma, vida nua e estado de exceção. In. Singularidade e subjetivação: Ensaios sobre clínica e cultura. Rio de Janeiro: 7Letras/Editora PUC-Rio, 2008.

(2013). Michael Balint: A originalidade de uma trajetória psicanalítica. Rio de Janeiro: Revinter, 2013.

PINHEIRO, Teresa. (1996). Trauma e melancolia. In. KATZ, Chaim S. (org.). Ferenczi: História, teoria, técnica. São Paulo: Editora 34, 1996. . (2016). Ferenczi. São Paulo: Casa do Psicólogo, 2016. 
RENTOUL, Robert W. (2010). Ferenczi's language of tenderness: Working with disturbances from the earliest years. Lanham: Jason Aronson, 2010.

RODMAN, F. Robert. (1972). A insistência em ser ele próprio. In. GIOVACCHINI, Peter. (org.). Táticas e técnicas psicanalíticas: D. W. Winnicott. Porto Alegre: Artes Médicas, 1995.

SAJTI, Enikő A. (2015). In trial and in anger with our roles in World War II: A collection of essays. In. The Hungarian Historical Review, v. 4, n. 3, p. 783-789, 2015 .

SALES, Jôse L. (2016). Clivagem: A noção de trauma desestruturante em Ferenczi. In. Arquivos Brasileiros de Psicologia, n. 68, v. 2, p. 60-70, 2016.

WINNICOTT, Donald W. (1945). Desenvolvimento emocional primitivo. In. Da pediatria à psicanálise: Obras escolhidas. Rio de Janeiro: Imago, 2000.

(1949). Memórias do nascimento, trauma do nascimento e ansiedade. In. Da pediatria à psicanálise: Obras escolhidas. Rio de Janeiro: Imago, 2000.

(1951). Objetos transicionais e fenômenos transicionais. In. Da pediatria à psicanálise: Obras escolhidas. Rio de Janeiro: Imago, 2000.

(1952). Psicoses e cuidados maternos. In. Da pediatria à psicanálise: Obras escolhidas. Rio de Janeiro: Imago, 2000.

(1954). Aspectos clínicos e metapsicológicos da regressão. In. Da pediatria à psicanálise: Obras escolhidas. Rio de Janeiro: Imago, 2000. . (1955a). A posição depressiva no desenvolvimento emocional normal. In. Da pediatria à psicanálise: Obras escolhidas. Rio de Janeiro: Imago, 2000. (1956a). A tendência anti-social. In. Da pediatria à psicanálise: Obras escolhidas. Rio de Janeiro: Imago, 2000. . (1956b). Formas clínicas da transferência. Da pediatria à psicanálise: Obras escolhidas. Rio de Janeiro: Imago, 2000. 
(1958). A capacidade para estar só. In. O ambiente e os processos de maturação. Porto Alegre: Artmed, 1983.

(1960a). Teoria do relacionamento paterno-infantil. In. O ambiente e os processos de maturação. Porto Alegre: Artmed, 1983.

(1960b). Distorção do ego em termos de falso e verdadeiro "self". In. O ambiente e os processos de maturação. Porto Alegre: Artmed, 1983.

. (1962a). A integração do ego no desenvolvimento da criança. In. O ambiente e os processos de maturação. Porto Alegre: Artmed, 1983.

. (1962b). Os objetivos do tratamento psicanalítico. In. O ambiente e os processos de maturação. Porto Alegre: Artmed, 1983.

(1963a). Da dependência à independência no desenvolvimento do indivíduo. In. O ambiente e os processos de maturação. Porto Alegre: Artmed, 1983.

(1963b). Dependência no cuidado do lactente, no cuidado da criança e na situação psicanalítica. In. $\mathrm{O}$ ambiente e os processos de maturação. Porto Alegre: Artmed, 1983.

(1964). The child, the family and the outside world. Cambdridge: Perseus Publishing, 1987.

. (1965). A família e o desenvolvimento do indivíduo. Belo Horizonte: Interlivros, 1980.

. (1966). A mãe devotada comum. In. Os bebês e suas mães. São Paulo: Martins Fontes, 2013.

(1967a). The concept of clinical regression compared with that of defence organization. In. Psycho-analytic explorations. Cambridge: Harvard University Press, 1989.

(1967b). O local da experiência cultural. In. O brincar e a realidade. Rio de Janeiro: Imago, 1975. 
(1968). A comunicação entre o bebê e a mãe e entre a mãe e o bebê: convergências e divergências. In. Os bebês e suas mães. São Paulo: Martins Fontes, 2013.

. (1969). O uso de um objeto. In. O brincar e a realidade. Rio de Janeiro: Imago, 1975.

. (1970). A experiência mãe-bebê de mutualidade. In. Explorações psicanalíticas. Porto Alegre: Artes Médicas, 1994.

(1988). Natureza humana. Rio de Janeiro: Imago, 1990.

ZIMERMAN, David E. (2004). Manual de técnica psicanalítica. São Paulo: Artmed, 2008. 